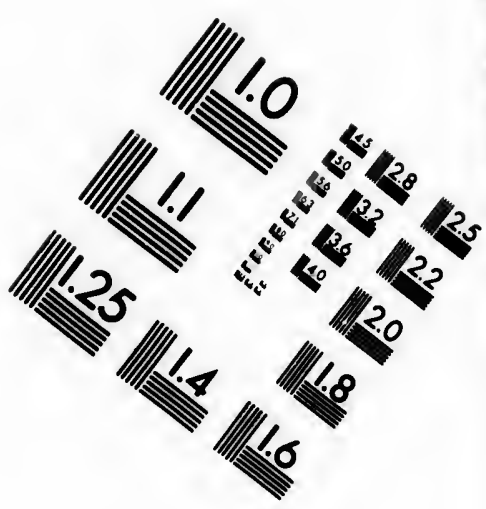

TEST TARGET (MT-3)
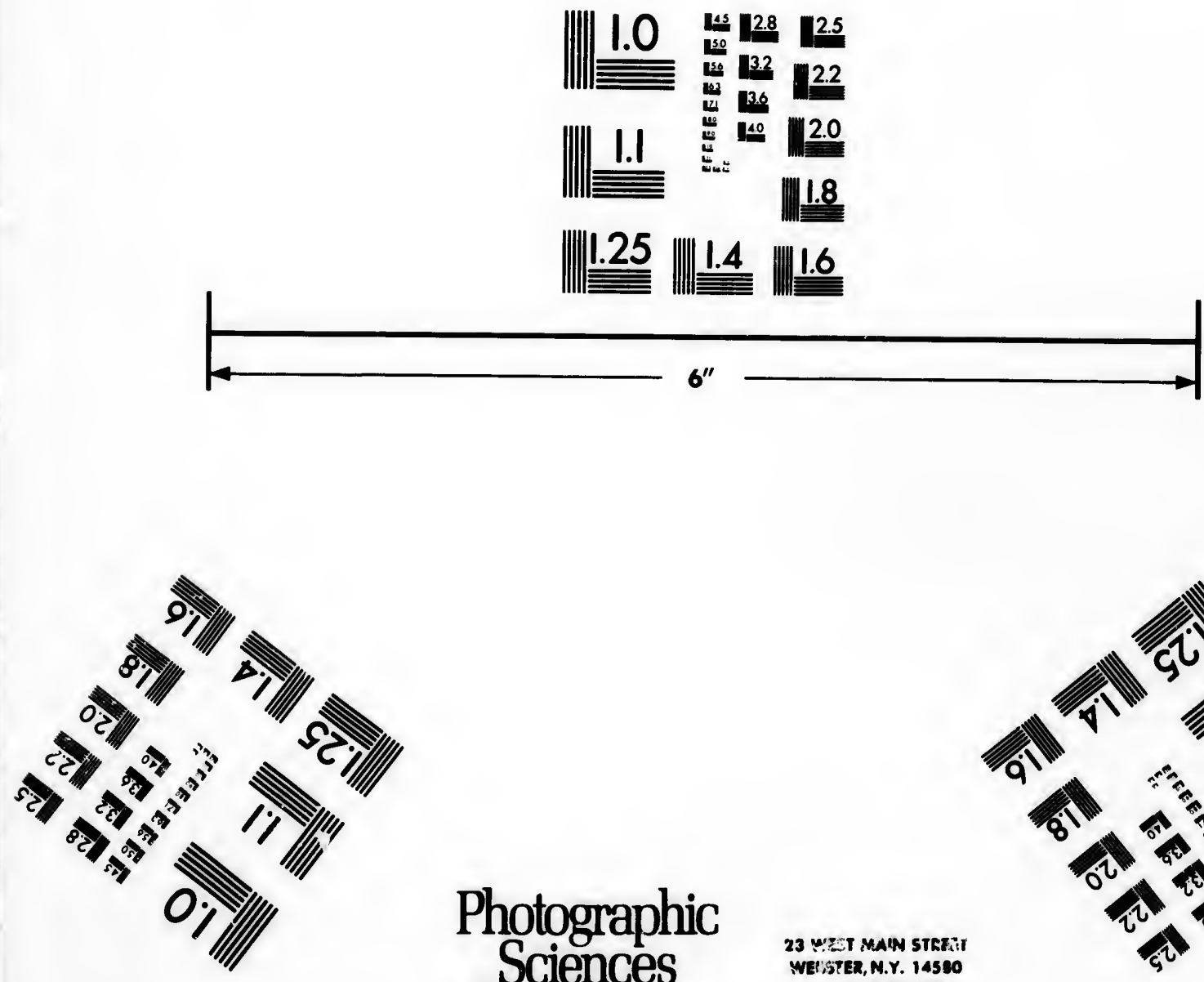

Photographic Sciences Corporation
23 WET MALN STRBiI WES'STER, M.Y. 14580

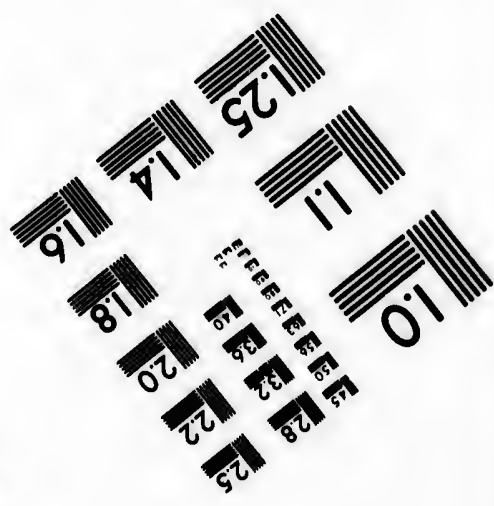



The Institute has attempted to obtain the best original copy available for filming. Features of this copy which may be bibliographically unique, which may alter any of the images in the reproduction, or which may significantly chenge the usual method of filming, are checked below.

Coloured covers/

Couverture de couleur

Covers damaged/

Couverture endonimagée

Covers restored and/or leminated/

Couverture restaurée et/ou pelliculée

Cover title missing/

Le titre de couverture manque

Coloured maps/

Cartes géographiques en couleur

Coloured ink (i.e. other than blue or black)/

Encre de couleur (i.e. autre que bleue ou noire)

Coloured plates and/or illustrations/

Planches et/ou illustrations en couleur

Bound with other material/

Relié avec d'autres documents

Tight binding may cause shadows or distortion along interior margin/

La re liure serrée peut causer de l'ombre ou de id distortion le long de la marge intérieure

Blank leaves added during restoration may appear within the text. Whenever possible, these have been omitted from filming/

II se peut que certaines pages blanches ajoutées lors d'une resteuration apparaissent dans le texte, mais, lorsque cela était possible, ces pages n'ont pas été filmées.

Additional comments:/

Commentaires supplémentaires:
L'Institut a microfilmé le meilleur exemplaire qu'il lui a été possible de se procurer. Les détails de cet exemplaire qui sont peut-être uniques du point de vue bibliographique, qui peuvent modifier une image reproduite, ou qui peuvent exiger une modification dans la méthode normale de filmage sont indiqués ci-dessous.

Coloured pages/

Pages de couleur

Pages damaged/

Pages endommagées

Pages restored and/or laminated/ Pages restaurées et/ou pelliculées

Pages discoloured, stained or foxed/

Pages décolorées, tachetées ou piquées

Pages deteched/

Pages détachées

Showthrough/

Transparence

Quality of print varies/

Qualité inégale de l'impression

Includes supplementary material/

Comprend du matériel supplémentaire

Only edition available/

Seule édition disponible

Pages wholly or partially obscured by erreta slips, tissues, etc.. have been refilmed to ensure the best possible image/ Les pages totalement ou partiellement obscurcies par un feuillet d'errata, une pel :re. etc., ont été filmées a nouveau de façon á obtenir la meilleure image possible.

This item is filmed at the reduction ratio checked below/ Ce document est filmé au taux de réduction indiqué ci-dessous. $10 x$ $14 x$ $18 x$ $22 x$ $26 x$ $30 x$

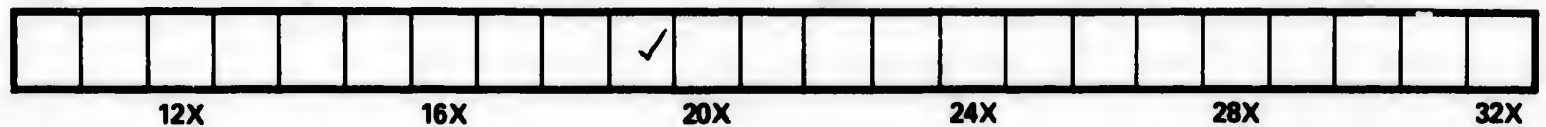


The copy filmed hore has been reproduced thanks. to the generosity of:

University of British Columbia Library

The imeges appeoring here are the best quality possible considering the condition and legibility of the original copy and in keoping with the filming contract epecifications.

Original copies in printed paper covers are filmed beginning with the front cover and onding on the last page with a printed or illustrated impression, or the back cover when appropriats. All other original copies are filmed beginning on the firat pege with a printed or lllustrated impression, and ending on the last page with a printed or lllustrated impression.

The leat recorded frame on each microfiche shall contain the symbol $\rightarrow$ (meaning "CONTINUED"), or the symbol $\nabla$ (meaning "END"), whichover epplies.

Maps, plates, charts, otc., may be filmed at different reduction ratios. Those too large to be entirely included in one exposure ore filmed beginning in the upper loft hand corner, loft to right and top to bottom, as many frames as required. The following diagrems illustrate the mothod:
L'oxemplaire filmo fut reproduit grace a la gónórositó de:

University of British Columbia Library

Les images suivantes ont bte reproduites avec lo plus grand soin, compte tenu de la condition ot de la nottots de l'exemplaire filmb. ot on conformite avec les conditions du contrat de vilimage.

Les exemplaires originaux dont la couverture on papier eat imprimbe sont filmbs on commencant par lo premier plat ot on torminant soit par la dernibre page qui comporte une emprainte d'impression ou d'illustration, soit par lo second plat, selon lo cas. Tous los autres exemplaires originaux sont filmos on commençant par le premiere page qui comporte une empreinte d'impression ou d'illustration ot en terminant par la dernibre page qui comporte une telle emprainte.

Un des symboles suivante apparaîtra sur la dernibre image de chaque microfiche, selon le cas: lo symbole $\rightarrow$ signifio "A SUIVRE", 10 symbole $\nabla$ signifie "FIN".

Les cartes, planches, tableaux, otc., peuvent otre filmbe des taux de réduction difforents.

Loraque le document est trop grand pour etre reproduit on un soul clichs, II est filme pertir de l'angle supbriour gauche, de gauche d droite, ot de haut on bas, on prenant le nombre d'images nocessaire. Les diagrammes suivants illustrent la mothode.
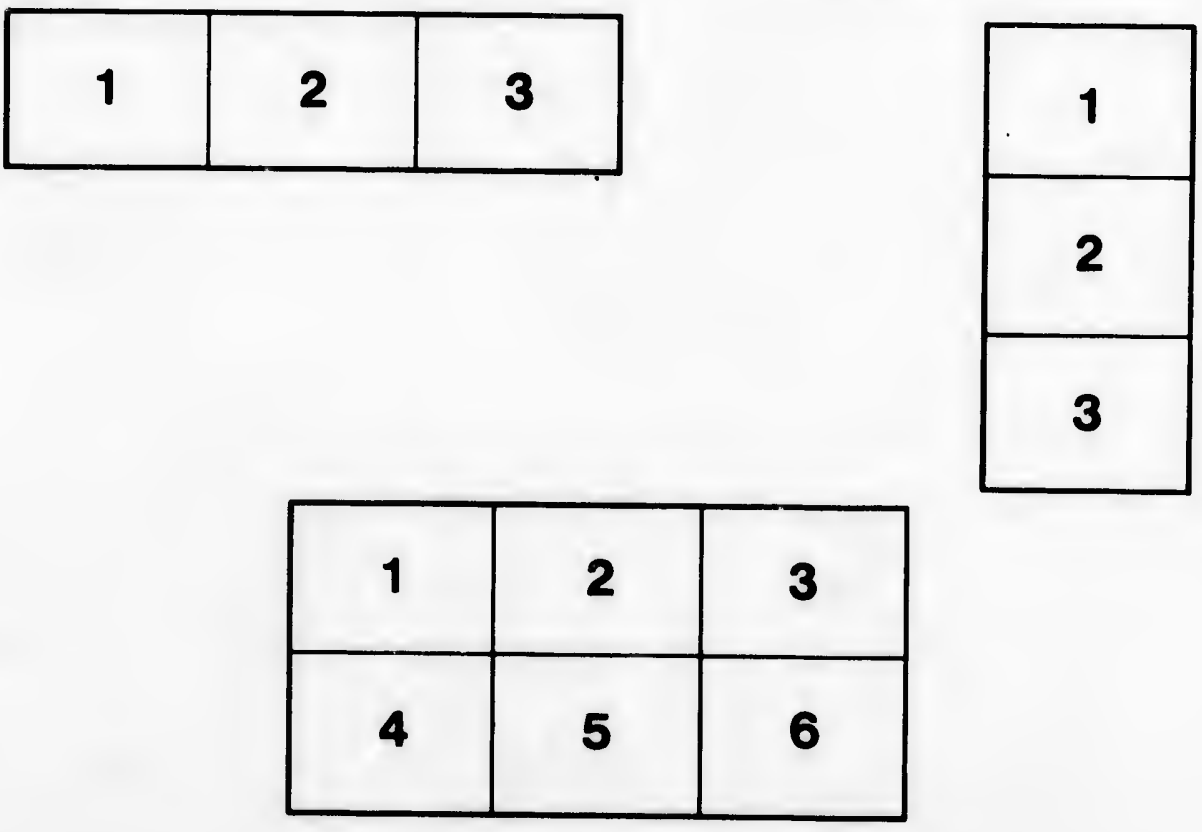



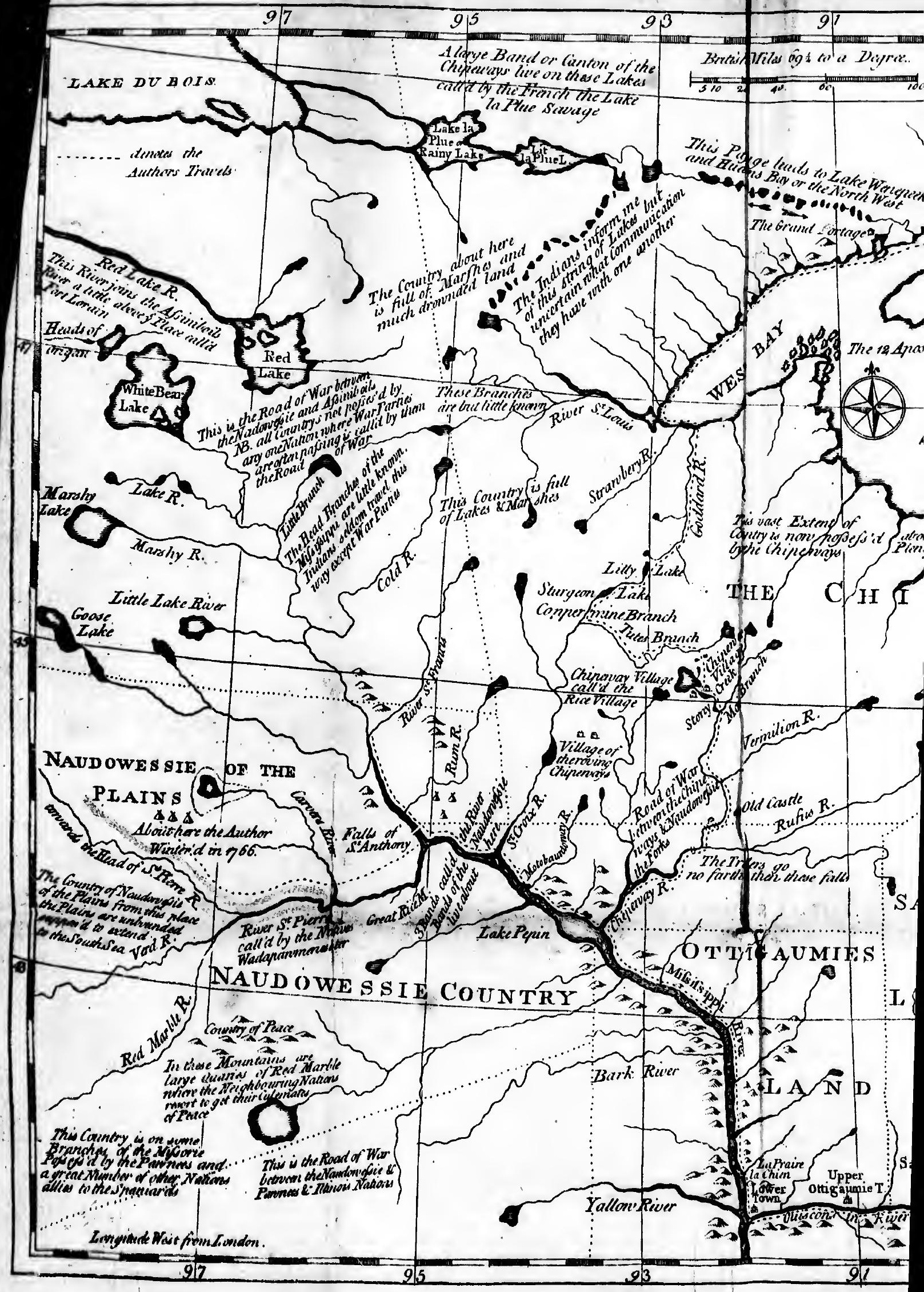




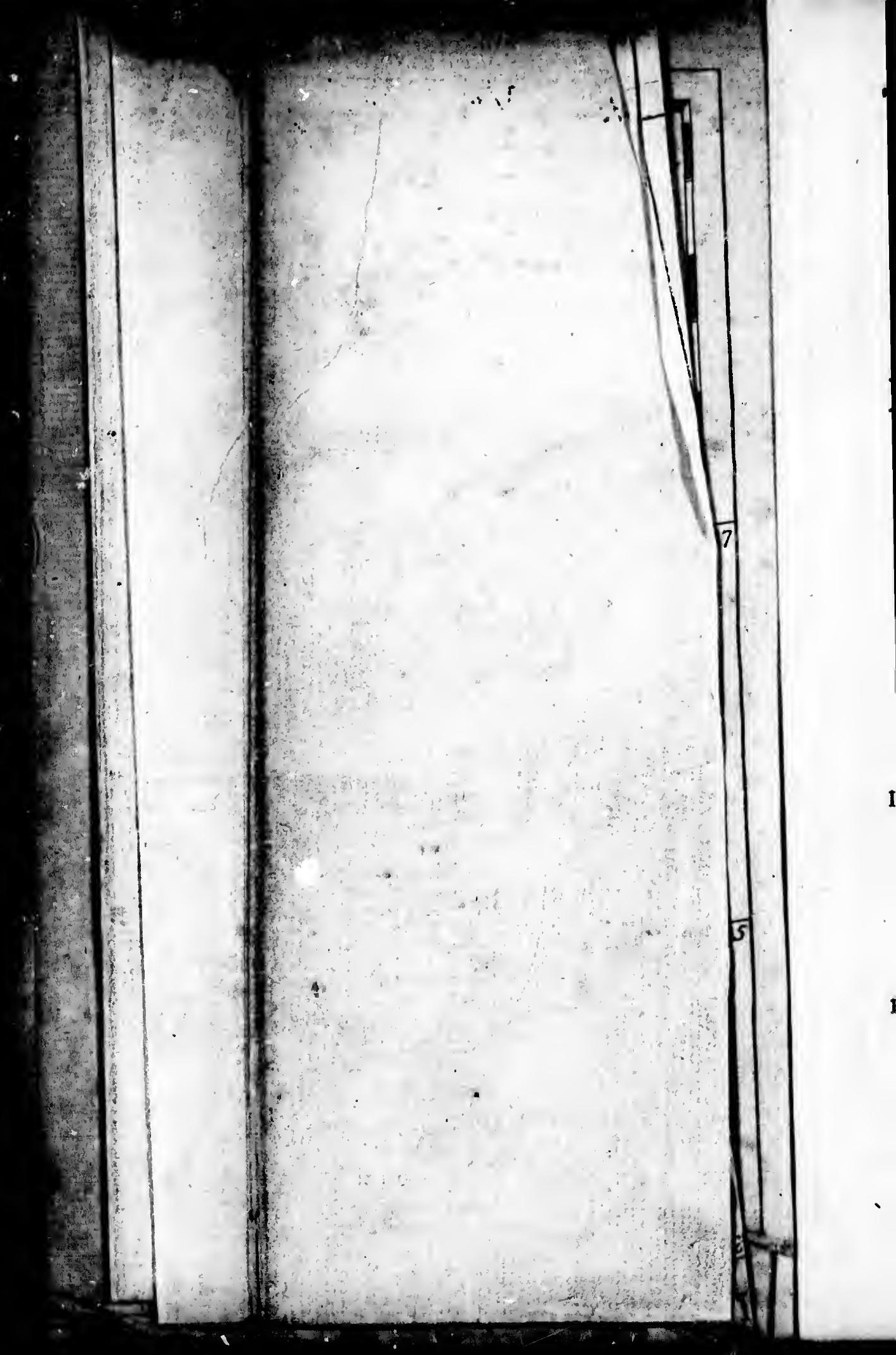


THROUGH THE

I N TER IOR PAR T S

O F

\title{
NOR'TH-A MERICA,
}

\author{
I N T H E
}

YEARS I 766,1767 , and 1768.

\section{BX J. C A R V E R, EsQ.}

CAPTAIN OF A COMPANY OF PROVINCIAL. TROOPS DURING THE LATE

WAR WITH FRANCE.

ILLUSTRATED WITH COPPER PLATES.

$$
\text { D U B L I N : }
$$

Printed for S. Price, R. Cross, W. Watson, W. and h. Whitestone, J. PotTs, J. Williams, W. Colles, W. Wilson, R. MONCRIEFFe, C. Jenkin, G.
BURNeT, T. WALKER, W. GILBRT, L. L. -

FLin, J. EXShaW, L. White, J. BEATtT, and $B$. Watson. MDCCLXXIX. 


$$
\begin{array}{r}
\text { N65 } \\
F 597 \\
C 33 \\
1779
\end{array}
$$

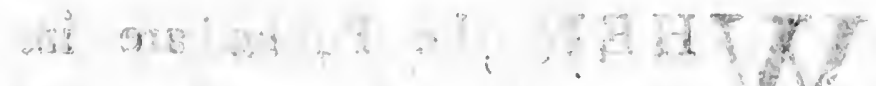
in id ynd

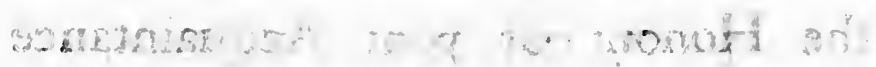

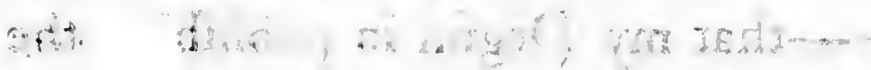

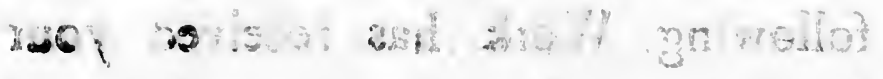

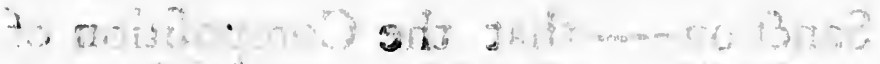

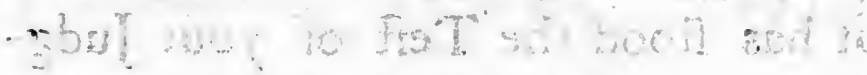

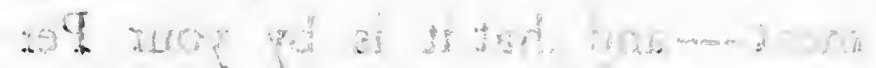

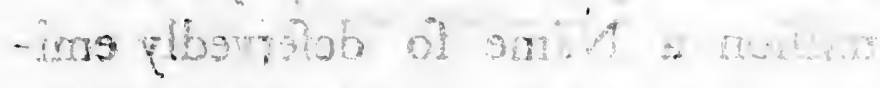

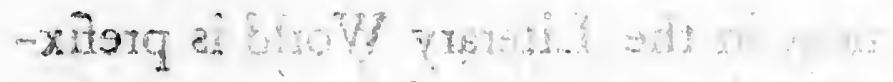

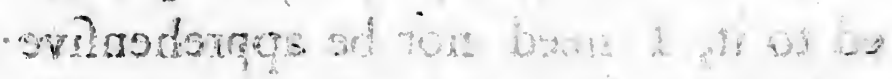

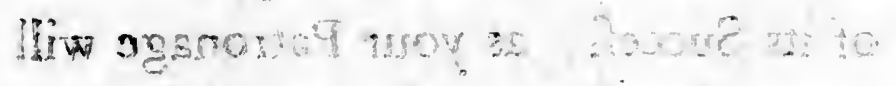

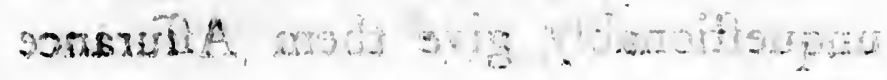

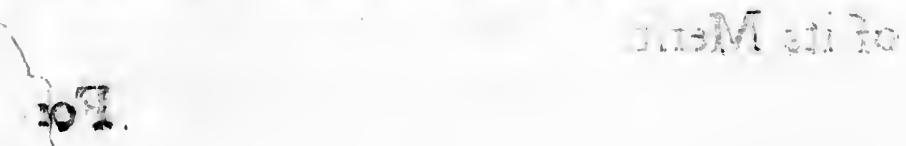




\section{JOSEPH BANKS, Efq. F.R.S.}

\section{S I R,}

$W_{\text {formed that I have long had }}^{\text {HEN the Public are in- }}$ the Honour of your Acquaintance --that my Degfin in publifhing the following Work has received your Sanction----that the Compofition of it has ftood the Teft of your Judgment---and that it is by your Permiffion a Name fo defervedly eminent in the Literary World is prefixed to it, I need not be apprehenfive of its Succefs; as your Patronage will unqueftionably give them Affurance of its Merit. 


\title{
D E D I C A
}

For this public Teftimeny of your Favour, in which $i$ pride myfelf, accept, Si:, my moft grateful Acknowledgments; and believe me to be, with great Refpect,

\section{Your obedient}

\section{humble Servant,}

\author{
LoN DOX, \\ June 20,1778 .
}


your

ac-

$10 \mathrm{w}-$

be,

\section{O N T E N T S.}

TNRODUCTION, The Autbor fets out from Bofton on his Travels; - - - 15 Defcription of Fort Micbillimackinac, 16 Fort La bay; I9 the Green Bays - 23 Liake Micbigan, - 25 Arrives at the Town of the Winnebagoes,

Excurfion of the Winnebagoes towards the Spanifs Settlements,

Defcription of the Winnebago Lake, -33 Inftance of Refolution of an Indian Woman. 37 Defcription of the Fox River, -... $3^{8}$ Remarkable Story of a Ratile Snake, _39 The great Town of the Saukies, ... 42 Upper Town of tbe Ottagaumies, $\therefore-.44$ Dejcription of the Ouifconfin River, ib. Lower Town of tbe Ottigaumies, or La Prairie Le Chien, - $\quad 46$ An Attack by jome Indian Plinderers, 47 


\section{O N T E N T S.}

Defcription of the Milllippi from tbe Mout's of the Ouifconfin to Lake Pepin, - 50 - Lake Pepin; - $5 \mathrm{I}$ Remarkable Ruins of an ancient Fortification,

The River bands of the Naadowefle Indians,

54

Adventure witb a Party of thefe, and fome of the Cbipézuays,

Defcription of a remarkable Cave, - 59 Uncommon Bebaviour of the Prince of the Winnebagoes at the Falls of St. Antbony, $6 \mathrm{I}$

Defcription of the Falls, 64 Extent of the Autbor's Travels, - $\quad 66$ Defcription of the River St. Pierre, - 69 Sources of the Four great Rivers of North America.

Reflections on their Affinity,

70

The Naudowelies of the Plains, with whom the Autbor reintered in the Year 1766,

The Autbor returns to the Moutb of the River St. Pierre, 79 Account of a violent Tbunder-florm, ib. Speech made by the Autbor in a Council beld by 


\section{O N T E N T S.}

beld by the Naudowefies at the great Cave,

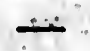

81.

Adventure with a Party of Indians near. Lake Pepin,

89

Defription of the Country adjacent to the River St. Pierre, - - - 93 Account. of different Clays found near the Marble River, Defcription of the Cbipezvay River, $\quad 96$ Extraordinary Effects of a Hurricane, $\quad 97$ The Autbor arrives at the Grand Portage on the Norib-zueft Borders of Lake Superior, - - 100 Account of the Lakes lying fartber to the Nortb-zoeft: Lake Bourbon, Lake Winnepeek, Lake Du Bois, Lake La Pluye, Red Lake, \&c. - - ror Account of a Nation of Indians fuppofed to bave been tributary to the Mexican Kings,

— the Sining Mountains,

113 A fingular Prediction of the Chief Prieft of the Killifinoes verified, - 116 D:fcription of Lake Superior, - 124 Story of the two Chipeways landing on the Ifland of Mauropas, Account of great 2uantities of Copper Ore, 


\section{O N T E T S.}

Defcription of the Falls of St. Marie, $\quad{ }_{34}$ Luke Huron, Saganaum and Tbuider Bays,

I37.

Extracordinary Pbanomenon in the Straiglits $\therefore$ of Micbillimackinac,

$13^{8}$

Defcription of Lake St. Claire,

142

the River, Toren, and Fort of

Detroit,

143

Remarkabie Rain at Detroit, _ $\quad 144$ Attack of Fort Detroit by Pontiac, $\quad 146$ Defcription of Lake Erie, - $\quad 157$

the River and Falls of Niagara,

- Lake Ontario, - 6 - 6 is. plain, and Lake George, - $\quad 162$ Account of a Tract of Land granted to Sir Ferdinando Gorges, and Captain Fobn Mafon, - 10.164 The Autbor's Motives for undertaking bis Travels, 167

\section{H A P. I.}

The Origin of the Indians,

171

Sentiments of various Writers on this Point,

17.2

Manfienr Charlevoix, -182 


\section{O N T E N T S.}

Sentiments of Fames Adair, Efg; - 191 - the Author of tbis:Work, 197 Corroboration of the Latter by Dactor Robinfon. 205

\section{H A P. II.}

Of the Perfons, Drefs, Ec. of the Indians, 203 An Account of thofe wbo bave written on this Subject, - i - 208 Defcription of the Perfons of the Indians, 211 their Drels, - the Drefs of the Chiperways, with a Plate, $\therefore \therefore-\quad-\quad 217$ suith Ditto, $\therefore-218$ The Manner in wobich they build their Tents 1 and Huts, Their domeftic Utengsls, 219 $22 I$

\section{.C H.A.P. III.}

Of the Manners, 2ualifications, Esc. of the CIndians, $-$

223 Peculiar Cufoms of the Women, - 224 The circumppect and foical Dispofiti of the Men,

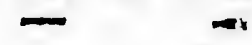

225

Their 


\section{O N T E N T S.}

Their amazing Sagacity, . - - 229 Remarkable Story of one of the Naudowefie Women,

The Liberality of the Indians, and tbeir Opinion respecting Money, - 234

\section{H A P. IV.}

Their Method of reckoning Time, Ec 237 The Names by which they diftinguijh the I. Montbs, - - ib. Their Idea of the Ufe of Figures, - 39

C HA P. V.

Of their Government, $\mathfrak{E}^{2} c . \quad-\quad-\quad 242$ Their Divifär into Iribes, s - ib. The Chiefs of their Bands, _- 243 The Members tbat compofe their Councils, 245 ¿C:H:A.P.IVI.

Of tbeir Feafs, .... - - 248

Tbeir ufual Food, - - 249

Their Manner of drefling and eating their Victuals, $25^{\circ}$ 


\section{CONTE N TS.}

C H A P. VII.

Of their Dances,

The Manner in which they dance,

251

The Pipe or Calumate Dance,

252

The War Dance,

-

$-\quad 253$

The Pawwaw Dance,

254

An uncominon Admiffion into a Society, among the Naudorve fies;

257

The Dance of the Indians on the Banks of tbe Miflaspi, referred to in the Fournal, 263

The Dance of the Sacrifice, 267.

\section{H A P. VIII.}

Of their Hunting,

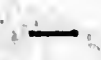

-

267

Their Preparation before they fet out, 269 Their Manner of bunting the Bear,

270 Buffalo, Deer,

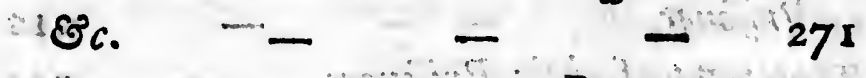
Beaver. 273

C H A P. 
Of their Manter of making War, \&c. 277 The Indian Weapons, roits a Plate, 279 Thbir Motives farmaking War. -280 Preparations before they take tbe Fiekh 284 The Manner in wobich they folicit otber $\mathrm{Na}$ -

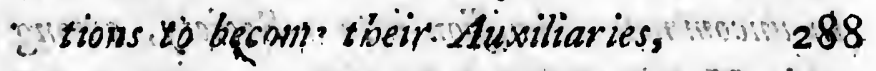
Fisir Manner of declaring: War wh 889 Thair Metbod of engaging their Enemies, 292 An Interice of the Efficacy of it in the Defeat C. of General Braddock, A Detail of the Maifacre at. For DKilliam Henry in the Year 1757 , Acutenefs and Alacrity of the Indians in purfuing their Enemies, - 308 Their manner of fcalping, ... - $\quad 309$ The Manner in wobich they retreat and carry off their Prijoners, - $\quad 3^{10}$ A remarkable Infance of Heroijm in a Eema'e

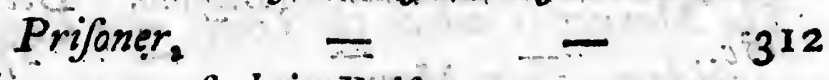
Treatment of their Prijoners, $-\quad 3^{1} 5$ The Origin of tbeir felling Slaves, $\quad 325$

C H A P. 


\section{H A P. X.}

Of their Manner of making Peace, $\mho_{c}$. 329 Account of an Engagement between the e Iroquois and the Ottagaumies and Saukies, $33^{\circ}$ Manner in abbich they conduct a Ireaty of :Pcace, $33^{6}$ Defcription of the Pipe of Peace, ib. - Belts of Wampumb; - 337 -CH A.P XY $\therefore$

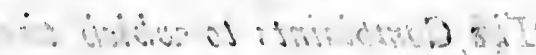
Of their Games, The Game of the Ball, -the Bowl or Platter, - 342 C H A P XII.

Qf their Marriage Cerenzeniess -344 The Manner in wbicb the Tribes near Ganada celebrate their Marriages, 346 The Form of Marriage among the Nauddoveffies,

Their Manner of carrying on an Intrigue, 352 Of the Indian Names,

- 354 C H A P. 


\section{ON T E N T S.}

\section{H A P. XIII.}

Of their Religian,

$$
\text { reme Being, }
$$

Their Ideas of a supreme Being,

Of their Priefs,

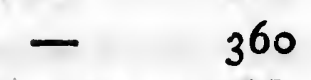

The Sentiments of Others on the religious

Principles of the Indians oppofed, $3^{62}$

\section{H A P. XIV:}

Of their Difeafes, \&ic. $\therefore$ -

$3^{6} 5$ The Complaints to wbich they are cbiefly jubject,

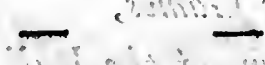

ib.

The Manner in which they conftruct tbeir Sreeating Stoves, - - 366 The Metbods in wbich tbey treat their Difeajes,
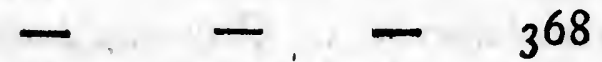

Ar extraordinary Instance of the foudgment of an Indian Woman in a depperate Cafe, $37 \mathrm{I}$

\section{H A P. XV.}

The Manner in cobich they treat their Dead,

373

A Spe- 


\section{CONTENTS.}

A Specimen of their Funcral Harangues, 374 Their Method of burying the Dead, 376 A jingular Infance of parental Affection in Naredoreeffie: Woman, $15-37^{8}$

$\therefore i$ C H A P._XVI.

A concife Cbaracter of the Indians, 382 Their perfonal and mental sualificdtions, $3^{8}$ Tibeir public Cibaracter as Members of a Com. munity, - -
- CHA $\mathrm{P}$ XVit:

Of their Language, Hieroglypbicks, 86. $3^{87}$. Of the Cbipeway Tongue,.. - $\quad 3^{89}$ Descriptive Specimen of their Hiereglyphicks, $\therefore+$ 390

Vocabulary of the Cbipéway Language, 393 - tbe Neudowe fle Lianguages 405

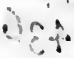
C H A P. XVIII.

Of. the Beafts, Birds, FifBes, VReptiles, and Dinfects, robich are foudd in the Interior Parts of North America, - 412 $B E A S T S$. 


\section{C $0 \mathrm{~N} T \mathrm{~T}$ E $\mathrm{N}$ T.}

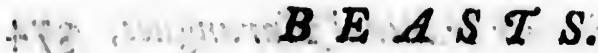

Tbe Tyger. The Bear,

Tbe Wolf. The Fox,

415

Dogs. The Cat of the Mountain. The Buffalo,
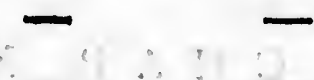

416

The Deer,

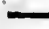

417

T.be Elk,

Tbe Mooje,
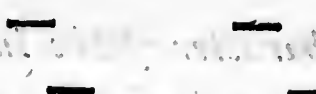

Tbe Carrabou. The Carcajou,

The Skunk,

Tbe Porcupine,

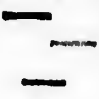

The Woodcbuck. The Racoon,

The Martin. 'The Muifquaß,

Squirtêts, a -

425

The Beaver,

The Otter, - - -

The Mink,

\section{$B I R D S$.}

The Eagle. The Nigbt Hawk, - 435 The Fifh Hawk, - $-43^{6}$ The Whipperwill, - - - ib. The Oriol The Crane, T 437 Ducks The Teal a 438 The Loon. Tbe Partridge, -439 a 2 LN 


\section{O N T E N T S.}

Tbe Woodpecker. The Blue Fay,

The Wakon Bird. The Blackbird,

The Redbird,

The Whetfaw. The King Bird. The

Humming Bird, - - 443

$$
\text { F I S HE S. }
$$

THe Sturgeon,

The Cat Fijh. The Carp. The Cbub, 445

$$
S E R P E N T S
$$

The Rattle Snake,

Tbe Long Black Snake. The Striped or Gar. - ter Snake. The Water Snake, The Hifing Snake. The Green Snake. The Thorn-tail Snake. The speckled Snake. The Ring Snake,

Tbe Truo-beaded Snake. The Tortoife or Lana

Turtle, 455

$$
L I Z A R D \text { S. }
$$

The Swift Lizard. The Slow Lizard. $45^{6}$ The T'bree Taad,

$$
\text { I N S E C T S. }
$$

The Lightning Bug or Fire Fly,

The Water Bug: The Horned Butg. 460 The Locuf? 
C O NTE N T 9

\section{H A P Xix}

Of the Trees, Shrubs, Roots, Herbs, Flowiors,

$$
\text { TREES 46r }
$$

The Oak,

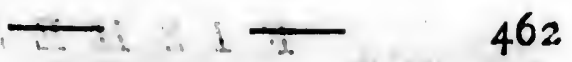

The Pine Tree. The Maple, $46_{3}$ The Afh, Tा1, $\cdots 464$ The Hemlock Tree, 465

The Bafs or White Wood. The Wickopick or Suckroick. The Button Wood, 466

$$
N U T \mathcal{T} R E S .
$$

The Butter or Oil Nut, $\quad--467$ The Beecb Nut. The Pecan Nut, 468 The Hickory, - - 469

$$
\text { F RUIT TREES. }
$$
Tbe Cberry Tree,

\section{$S H R U B S$.}

TheWillow, . - -

$47^{1}$

The Sbin Wood. The Safjafras, $47^{2}$ The Prickly Afs. The Moofe Wood. The Spoon Wood. The Alder. 


\section{O. N T E T S.}

The Sbrub Oak.

The Witch Hazle. The Myrtle,

Winter Green The Fever Buß,

The Cranbergy Bußh. The Cboak Berry, 477

ROOTS and PLANTS.

spikenard. Sarfaparilla,

478

Ginfang.

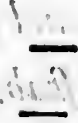

Gold Thread. Solomon's Seal. Devil's

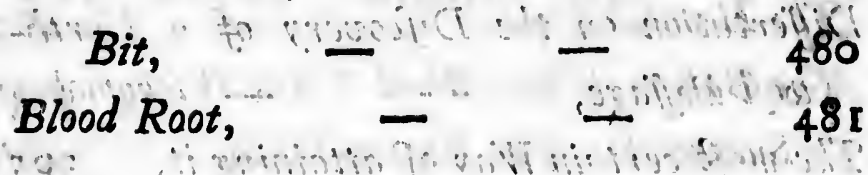

\section{$H E R B S$}

Sanicle. Rattle Snake Plantain, - 482 Poor Robin's Plantain. Toad Plantain. Rock Liverwort. Gargit or Skoke, 483 Skunk Cabbage or Poke. Wake Robin, 484 Wild Indico. Cat Mint, - 485

$$
\text { FLOWERS, : } 486
$$

FARINACEOUS and LEGUMINOUSROOTS, EC.

Maize or Indian Corn. Wild Rice, 487 Beans, 490 The Squaf,

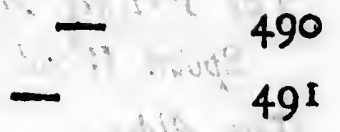




\section{O T $\mathrm{T}$ T S}

\section{A.P. E N DIX.}

The Probability of the interior Parts of North Americu becoming commerciatColonies, 493 The means by wibidb tbis might be effected, 495 Tracts of Land pointed out, on which Colonies may be effablifhed woitb the greatef Ady vantage, $w$ ? - 497 Differtation on the Difconvery of a Nortbweft Paffage,

The moft certain Way of attaining it, 505 Plan proposed by Richard Whitworth, ESq; - for making on Attemp? from a 2uarter bitberto unexplored, - - 500 The Reafon of its being poffponed; -5507

I N T R O () 


\section{N T RODUCTION.}

$\mathrm{O}$ fooner was the late War with
France concluded, and Peace eftablifhed by the Treaty of Verfailles in the Year 1763 , than I began to confider (having rendered my' country fome fervices during the war) how I might continue ftill ferviceable, and contribute, as much as lay in my power, to make that vaft acquifition of territory, gained by Great Britain, in North America advantageous to it. It appeared to me indifpenfably needful, that Government fhould be acquainted in the firft place with the true ftate of the dominions they were now become poffeffed of. To this purpofe, I determined, as the next proof of my zeal, to explore the moft unknown parts of them, and to fpare no trouble or expence in acquiring a knowledge that promifed to be fo ufeful to my countrymen. I knew that many obftructions would arife to my fcheme 


\section{[ ii ]}

from the want of new Maps and Charts; for the French, whillt they retained their power in North America, had taken every artful method to keep all other nations, particulasly the Englifh, in ignorance of the concerns of the interior parts of it: and to accomplin this defign with the greater certainty, they had publifhed inaccurate maps and falfe accounts; calling the different nations of the Indians, by nicknames they had given them, and not by thofe really appertaining to them. Whether the intention of the French in doing this, was to prevent thefe nations from being difcovered and traded with, or to conceal their difcourfe, when they talked to each other of the Indian concerns, in their prefence, I will not determine; but whatfoever was the caufe from which it arofe, it tended to minlead,

As a proof that the Englifh had been greatly deceived by thefe accounts, and that their knowledge relative to Canada had ufually been very confined, before the conqueft of Crown-point in 1759, it had been efteemed an impregnable fortrefs: but no fooner was it taken, than we were convineed that it had acquired its greateft fecurity

from 


\section{[ iii ]}

from falfe reports, given out by its poffeffors, and might have been battered down with a few four pounders. Even its fituation, which was reprefented to be fo very advantageous, was found to owe its advantages to the fame fource. It cannot be denied but that fome maps of thefe countries have been publifhed by the French with an appearance of accuracy; but thefe are of fo fmall a fize and drawn on fo minute a fcale, that they are nearly inexplicable. The fources of the Miffiffippi, I can affert from my own experience, are greatly mifplaced, for when I had explored them, and compared their fituation with the French Charts, I found them very erroneoufly reprefented, and am fatisfied that thefe were only copied from the rude ketches of the Indians.

$\because$ Even fo lately as their evacuation of $\mathrm{Ca}$ nada they continued their fchemes to deceive, leaving no traces by which any knowledge might accrue to their conquerors : for though they were well acquainted with all the Lakes, particularly with Lake Superior, having conftantly a veffel of confiderable burthen thereon, yet their plans of them are very incorreit. I difcovered many errors in 


\section{[ iv ]}

the defcription given therein of its Inands and Bays, during a progrefs of eleven hundred miles that I coafted it in canoes. They. likewife, on giving up the poffeffion of them, took care to leave the places they had occupied in the fame uncultivated ftato they had found them; at the fame time defiroying all their naval force. I obferved myfelf part of the hulk of a very large verfel burnt to the water's edge, juft at the opening from the Straits of St. Marie's into the Lake.

Thefe difficulties, however, were not fufficient to deter me from the undertaking, and I made preparations for fetting out. What I chiefly had in yiew, after gaining a knowledge of the Manners, Cuftoms, Languages, Soil, and natural Productions of the different nations that inhabit the back of the Miffifippi, was to afcertain the Breadth of that vaft continent, which extends from the Atlantic to the Pacific Ocean, in its broddeff part between 43 and 46 Degrees Norttiern Latitude Had I been able to accomplifh this, I intended to have propofed to Governinetit to eftablin a Pof in fome of thofe parts about the Straits of Annian, which 


\section{$[\mathbf{v}]$}

which having been firft difcovered by Sir Francis Drake, of courfe belong to the Englifh. This I am convincéd would greatly facilitate the difcovery of a North-Weft Pafrage, or a communication between Hudfon's Bay and the Pacific Ocean. An event fo defirable, and which has been fo often fought for, but without fuccefs. Befides this important end, a fettlement on that extremity of America would anfwer many good purpofes, and repay every expence the eftablinment of it might occafion. For it would not only difclofe new fources of trade, and promote many ufeful difcoveries, but would open a paffage for conveying intelligence to China, and the Englin fettiements in the Eaft Indies, with greater expedition than a tedious voyage by the Cape of Good Hope, or the Straits of Magellan will allow of.

How far the advantages arifing from fuch an enterprize may extend, can only be afcertained by the favourable concurrence of future events. But that the completion of the fcheme, I have had the honour of fint planning and attempting, will fome time or other be effected, I make no doubt. From the unhappy divifions that at prefent fubfift

between 


\section{[ vi ]}

between Great Britain and America, it will probably be fome years before the attempt is repeated ; but whenever it is, and the exe-? cution of it carried on with propriety, thofe who are fo fortunate as to fucceed, will reap, exclufive of the national advantages that muft enfue, cmoluments beyond their moft fanguine expectations. And whilft their fpirits are elated by their fuccers, perhaps they may beftow fome commendations and bleffings on the perfon that firft pointed out to. them the way. Thefe, though but a thadowy recompence for all my toil, 1 thall receive with pleafure.

To what power or authority this new world will become dependent, after it has arifen from its prefent uncultivated ftate, time alone can difcover. But as the feat of Empire, from time immemorial has been gradually progreffive towards the Weft, there is no doubt but that at fome future period, mighty kingdoms will emerge from the fe wilderneffes, and ftately palaces and folemn temples, with gilded fpires reaching the nkies, fupplant the Indian huts, whole only decorations are the barbarous trophies of their vanquillied enemies. 


\section{[ vii ]}

As fome of the preceding paffages have already informed the Reader that the plan I had laid down for penetrating to the Pacific Ocean, proved abortive, it is neceffary to add, that this proceeded not from its impracticability (for the farther I went the more convinced I was that it could certainly be ascomplifhed) but from unforefeen difappointments. However, I proceeded fo far, that I was able to make fuch difcoveries as will be ufeful in any future attempt, and prove a good foundation for fome more fortunate Succeffor to build upon. There I thall now lay before the Public in the following pages; and am fatisfied that the greateft part of them have never been publimed by any perfon that has hitherto treated of the interior Nations of the Indians; particularly, the account I give of the Naudowefies, and the fituation of the Heads of the four great $r$ vers that take their rife within a few leagues of each other, nearly about the center of this great continent; viz. The River Bourbon, which empties itfelf into Hudion's Bay; the Waters of St. Lawrence; the Miffiflppi, and the River Oregon, or the River B 4 . 


\section{[ viii ]}

of the Weft, that falls into the Pacific Ocean at the ftraits of Annian.

The impediments that occafioned my returning, before I had accomplined my purpofes, were thefe. On my arrival at $\mathrm{Mi}$ chillimackinac, the remoteft Englim poft, in September I 766, I applied to Mr. Rogers, who was then governor of it, to furnith ne with a proper affortment of goods, as prefents for the Indians, who inhabit the track I intended to purfue. He did this only in part; but promifed to fupply me with fuch as were neceffary, when I reached the Fallo of Saint Anthony. I afterwards learned, that the governor fulfilled his promife in ordering the goods to be delivered to me; but thofe to whofe care he intrufted them, inftead of conforming to his orders, difpofed of them elfewhere.

Difappointed in my expectations from this quarter, I thought it neceffary to return to La Prairé Le Chien; for it was impoffible to proceed any further without prefents to enfureme a favourable reception. This I did in the beginning of the year 1767 , and finding my progrefs to the Weftward thus retarded, I determined to direct my courfe North-

ward. 


\section{[ ix ]}

ward. I took this ftep with a view of finding a communication from the Heads of the Miffulfippi into Lake Superior, in order to meet, at the grand Portage on the North weft fide of that lake, the traders that ufually come, about this feafon, from Michillimackinac. Of thefe I intended to purchafe goods, and then to purfue my journey from that quarter by way of the lakes Le Pluye, Dubois, and Ouinipique to the Heads of the river of the Weit, which, as I have faid before, falls into the fraits of Annian, the termination of my intended progrefs.

I accomplifhed the former part of my defign, and reached Lake Superior in proper time; but unluckily the traders I met thero acquainted me, that they had no goods to fpare, thofe they had with them being barely fufficient to anfwer their own demands in thefe remote parts. Thus difappointed a fecond time, 1 found myfelf obliged to return to the place from whence I began my expedition, which I did after continuing foma months on the North and Eaft borders of Lake Superior, and exploring the Bays and Rivers that empty themfelves into this large body of water. 


$$
\text { [ } \div \text { ] }
$$

As it miy be expected that I Thould lay before the Public the reafons that thefe difcoveries, of fo much importance to every one that has any connections with America, have not been imparted to them before, notwithftanding they were made upwards of ten years ago, I will give them to the world in a plain and candid manner, and without mingling with them any complaints on account of

- the ill-treatment I have received.

On my aritival in England, $I$ prefented a petition to his Majefty in conncil, praying for a reimburfement of thofe fums I had expended in the fervice of government. This was referred to the Lords Commiffioners of Trade and Plantations. Their Lordhips from the tenor of it thought the intelligence I could give of 10 much importance to the nation that they ordered me to appear before the Board. This meffage I obeyed, and underwent a long cxamination, inuch $I$ believe to the fatisfaction of cvery Lord prefent. When it was finifhed, I requefted to know what $I$ fhould do with my papers; without hefitation the firft Lord replied, that I might publin then whenever I pleafed. In confequence of this permiffion, I difpofed of them to a book

feller: 


\section{[ $x i$ ]}

feller: but when they were nearly ready for the prefs, an order was iffued from the council board, requiring me to deliver, without delay, into the Plantation Office all my charts, and journals, with every paper relative to the difcoveries I had made. In order to obey this command, I was obliged to repurchafe them from the bookfeller, at a very great expence, and deliver them up. This frefh difburfement I endeavoured to get annexed to the account I had already delivered in ; but the requeft was denied me, notwithftanding I had only acted, in the difpofal of my papers, conformably to the permiffion I had received from the Board of Trade. This lofs, which amounted to a very confiderable fum, I was obliged to bear, and to reft fatisfied with an indemnification for my other expences.

Thus fituated, my only expectations are from the favour of a generous Public to whom I Ahall now communicate my plans, journals, and obfervations, of which Iluckily kept copies, when I delivered the originals into the Plantation Office. And this I do the more readily, as I hear they are miflaid; and there is no probability of their ever.

being 


\section{[ xii ]}

being publifhed. To thofe who are interefted in the concerns of the interior parts of North America, from ine contiguity of their. poffeffions, or commercial engagements, they will be extremely ufeful, and fully repay the fum at which they are purchafed. To thofe, who, from a laudable curiofity, wilh to be acquainted with the manners and cuftoms of every inhabitant of this globe, the accounts here given of the various nations that inhabit fo vaft a track of it, a country hitherto almoft unexplored, will furnith an ample fund of amufeinent, and gratify their moft curious expectations. And I flatter myfelf they will be as favourably received by the Public, as deforiptions of iflands; which afford no other cntertainment than what arifes from their novelty; and difcoveries, that feem to promife very few advantages to this country, though acquired at an immenfe expence.

To make the following Work as comprehenfible and entertrining as poffible, I fhall firft give my. Readers an account of the route I purfued over this immenfe continent ithrough which they will be able to attend me by referring to the plan prefixed) and as I pafs on, deferibe the number of Inhabitants,

the 
the fruation. of the Rivers and Lakes, and the productions of the country. Having done this, I thall treat, in diftinct Chapters, of the Manners, Cuftoms, and Languages of the Indians, and to complete the whole, add a Vocabulary of the Words moftly in ufe among them.

And here it is neceffary to befpeak the candour of the learned part of my Readers in the perufal of it, as it is the production of a perfon unufed, from oppofite avocations, to literary purfuits. He therefore begs they would not examine it with too critical an cye; efpecially when he affures them that his attention has been more employed on giving a juft defcription of a country that promifes, in fome future period, to be an inexhauftible fource of riches to that people who thall be fo fortunate as to poffefs it, than on the ftile or compofition, and more careful to render his language intelligible and explicit, than fmooth and florid.

routa tinent atteind arid as tants, 


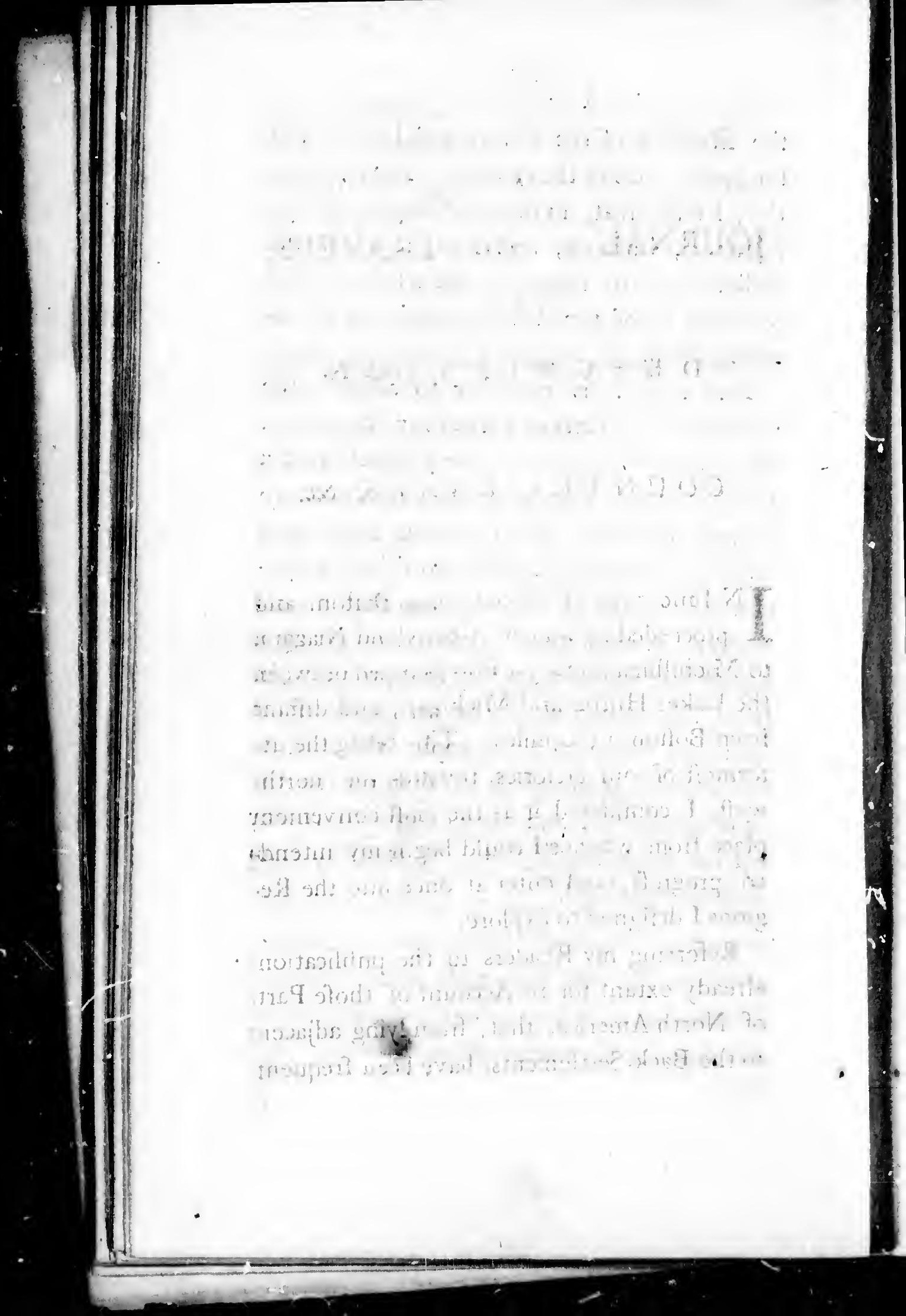




\title{
JOURNAL OF THE TRAVELS,
} W I T H A

\author{
D E S C R I P T I O N \\ O F T H E
}

C O U N T RY, L A K ES, \&c.

T June I766, I fet out from Bofton, and $\mathcal{L}$ proceeded by way of Albany and Niagara, to Michillimackinac; a Fort fituated between the Lakes Huron and Michigan, and diftant from Bofton 1300 miles. This being the uttermoft of our factories towards the northweft, I confidered it as the moft convenient place from whence I could begin my intended progreis, and enter at once into the Regions I defigned to explore.

Referring my Readers to the publications already extant for an Account of thofe Parts of North America, that, from lying adjacent to the Back-Settlements, have been frequent- 


\section{(16)}

ly defcribed, I hall confine myfelf to a Defcription of the more interior parts of it, which having been but feldom vifited, are confequently but little knowirn. In doing this, I thall in no inftance exceed the bounds of truth, or have recourfe to thofe ufelefs and extravagant exaggerations too often made ufe of by travellers, to excite the curiofity of the public, or to increafe their own importance. Nor thall I infert any obfervations, but finch as I have made myfelf, or, from the credibility of thore by whom they were related, am enabled to vouch for their authenticity.

Michillimackinac, from whence I began my travels, is a Fort conpofed of a frong ftockade, and is ufually defended by a garrifon of one hundred men. It contains about thirty houfes, one of which belcings to the governor, and another to the commiffary. Several traders alfo dwell within its fortiflcations, who find it a convenient fituation to traffic with the neighbouring nations. Michillimackinac, in the language of the Chipeway Indians, fignifies a Tortoife; and the place is fuppofed to receive its name from -an Ifland, lyil $\mathrm{g}$ about fix or feven miles to the 
a De-

of it,

ed, are

doing bounds ufelefs often he cuir own bfervaelf, or, m they or their

began ftróng a gardins acaigs to miffary. fortifation to $\therefore \mathrm{Mi}-$ he Chiand the e from iles to the

the north-eaft, within fight of the Fort, which has the appearance of that animal.

During the Indian war that followed foop after the Conqueft of Canada in the year 1763 , and which was carried on by an army of confederate i,ations compored of the Hurons, Miamies, Chipeways, Ottoways, Pontowattimies, Miffiffauges, and fome other tribes, under the direction of Pontiac, a celebrated Indian warrior, who had always been in the French intereft, it was taken by furprize in the following manner. The Indians having fettled their plan, drew near the Fort and began a game at Ball, a paftime much ufed among them, and not unlike tennis. In the height of their game, at which fome of the Englifh officers, not furpecting any deceit, ftood looking on, they fruck the ball, as if by accident, over the ftockade; this they repeated two or three times, to nake the deception more complete, till at longth, having by this means lulled every fufpicion of the centry at the fouth gate, a party rufhed by him; and the reft foon following, they took poffeffion of the Fort, without meeting with any oppofition. Having accomplifhed their defign, the Indians 


\section{$\left(\begin{array}{rl}18 \\ 8\end{array}\right)$}

had the humanity to fpare the lives of the greateft part of the garrifon and traders, but they made them all prifoners, and carried them off. However fnme time after they took them to Montreal, where they were redeemed at a good price. The Fort alfo was given up again to the Englifh at the peace made with Pontiac by the commander of Detroit the year following.

Having here made the neceffary difpofitions for . iuing my travels, and obtained a credit from Mr. Rugers, the governor, on fome Englifh and Canadian traders who were going to trade on the Miffiffippi, and received alfo from him a promife of a frem fupply of goods when I reached the Falls of Saint Anthony, I left the Fort on the $3^{d}$ of September, in company with thefe traders. It was agreed, that they thould furnifh me with fuch goods as I might want, for prefents to the Indian chiefs, during my continuance with them, agreeable to the governor's order. But when $I$ arrived at the extent of their route, I was to find other guides, and to depend on the goods the governor had promifed to fupply me with. 


\section{(19)}

We accordingly fet out together, and on the 18 th arrived at Fort $\mathrm{La}$ Bay. This Fort is fituated on the fouthern extremity of a Bay in Lake Michigan, termed by the French the Bay of Puants ; but which fince the Englifh have gained poffeffion of all the fettlements on this part of the Continent, is called by them the Green Bay. The reafon of its being thus denominated, is from its appearance; for on leaving Michillimackinac in the fpring feafon, though the trees there have not even put forth their buds, yet you find the country around La Bay, notwithftanding the paffage has not exceeded fourteen days, covered with the finett verdure, and vegetation as forward as it could be were it fummer.

This Fort, alfo, is only furrounded by a ftockade, and being much decayed is fcarcely defenfible againft fmall arms. It was built by the French for the protection of their trade, fome time before they were forced to relinquirh it; and when Canada and its dependencies were furrendered to the Englim, it was immediately garrifoned with an officer and thirty men. Thefe were made prifoners by the Menomonies foon after the furprife

C 2 of 


\section{(20)}

of Michillimackinac, and the Fort has neither been garrifoned or kept in repair fince.

The Bay is about ninety miles long, bụt differs much in its breadth; being in fome places only fifteen miles, in others from twenty to thirty." It lies nearly from northeaft to fouth-weff. At the entrance of it from the Lake are a ftring of iflands, extending from north to fouth, called the Grand Traverfe. Thefe are about thirty miles in length, and ferve to facilitate the paffage of canoes, as they thelter them from the winds, which fometimes come with violence acrofs the Lake. On the fide that lies to the fouth-eaft is the neareft and beft navigation.

The inlands of the Grand Traverfe are moftly finall and rocky. Many of the rocks are of an amazing fize, and appear as if they had been farhioned by the hands of artifts. On the largeft and beft of thefe iflands ftands a town of the Ottowaws, at which 1 found one of the moft confiderable chiefs of that nation; who received me with every honour he could poffibly thow to a ftranger. But what appeared extremely fingular to me at the time, and muft do fo to every perfon 


\section{(2I)}

is neifince. g, buit fome from northof it xtendGrand iles in paffage m the iólence to the javiga-

re are e rocks if they àrtifts. ftands found ff that honour Büt me at pérfón unac-

unacquainted with the cuftoms of the Indians, was the reception I met with on landing. As our canoes approached the More, and had reached within about threefcore rods of it, the Indians began a feu-de-joy; in which they fired their pieces loaded with balls; but at the fame time they took care to difcharge them in fuch a manner, as to fly. a few yards above our heads: during this they ran from one tree or fump to another, thouting and behaving as if they were in the heat of battle. At firft I was greatly furprifed, and was on the point of ordering my attendants to return their fire, concluding that their intentions were hoftile; but being undeceived by fame of the traders, who informed me that this was their ufual method of receiving the chiefs of other nations, I confidered it in its true light, and was pleared with the refpect thus paid me.

I remained here one night. Among the prefents I made the chiefs, were fome fpirituous liquors; with which they made themfelves merry, and all joined in a dance, that lafted the greateft part of the night. In the morning when I departed, the chief attended me to the fhore, and, as foon as I had embarked, 


\section{(22)}

embarked, offered up, in an audible voice, and with great folemnity, a fervent prayer in my behalf. He prayed " that the Great Spirit would favour me with a profperous voyage; that he would give me an unclouded $1 \mathrm{ky}$, and fmooth waters, by day, and that I might lie down by night, on a beaver blanket, enjoying uninterrupted fleep, and pleafant dreams : and alfo, that I might find continual protection under the great pipe of peace." In this manner he continued his petitions till I could no longer hear them.

I muft here obferve, that notwithftanding the inhabitants of Europe are apt to entertain horrid ideas of the ferocity of thefe favages, as they are termed, I received from every tribe of them in the interior parts, the mort hof pitable and courteous treatment; and am convinced, that till they are contaminated by the example and fpirituous liquors of their more refined neighbours, they retain this friendly and inoffenfive conduct towards ftrangers. Their inveteracy and cruelty to their enemies I acknowledge to be a great abatement of the favourable opinion I would wirh to entertain of them; but this failing is hereditary, and having received the fanc- 


\section{( 23.)}

tion of immemorial cuftom, has taken too deep root in their minds to be ever extirpated.

Arnong this people I eat of a very uncommon kind of bread. The Indians, in general, ufe but little of this nutritious food: whilft their corn is in the milk, as they term it, that is, juft before it begins to ripen, they flice off the kernels from the cob to which they grow, and knead them into pafte. This they are enabled to do without the addition of any liquid, by the milk that flows from them; and when it is effected, they parcel it out into cakes, and inclofing them in leaves of the baffwood tree, place them in hot embers, where they are foon baked. And better flavoured bread I never eat in any country.

This place is only a fmall village, containing about twenty-five houfes and fixty or feventy warriors. I found nothing there worthy of further remark.

The land on the fouth-eaft fide of the Grien Bay is but very indifferent, being overfprcad with a heavy growth of hemlock, pine, ipruce and fir trees. The communication betweer Lake Michigan, and the

Green 


\section{( 24$)$}

Gteen Bay has been reported by fome to be impradticable for the paffage of any veffels larger than canoes or boats, on account of the fhoals that lie between the iffands in the Grand Traverfe; but on founding it, I found fufficient depth for a veffel of fixty tons, and the breadth proportionable.

The land adjoining to the bottom of this Bay is very fertile; the country in general level, and the perfpective view of it pleafing and extenfive.

A fer families live in the Fort, which lies on the weft-fide of the Fox river, and oppofite to it; on the eaft-fide of its entrance, are fome French fettlers who cultivate the Ind, and appear to live very comfortably.

The Green Bay or Bay of Puants is one of thore places to which the French (as I mentioned in the introduction) have given nick-names. It is terined by the inhabitants of its coufts, the Menomonie Bay, but why the French have denominated it the Puant or Stinking Bay I kriow not. The reafon they themfelves give for it is, that it was not with a view to millead ftrangers, but that by adopiing this method they could converfe with each other, concerning the Indians, in

their 


\section{( 25$)$}

their prefence, without being underftood by them. For it was remarked by the perfons who firft traded among thein, that when they were fpeaking to each other about them, and mentioned their proper name, they inftantly grew fufpicious, and concluded that their vifiters were either fpeaking ill of them, or plotting their deftruction. To remedy this they gave them fome other name. The only bad confequences arifing from the practice then introduced is, that Englin and French geographers, in their plans of the interior parts of America give different names to the fame people, and thereby perplex thofe who have occafion to refer to them.

Lake Michigan, of which the Green Bay is a part, is divided on the north-eaft from Lake Huron by the Straits of Michillimackinac; and is fituated between forty-two and forty-fix degrees of latitude, and between eighty-four and eighty-ieven degrees of weft longitude. Its greateft length is two hundred and eighty miles, its breadth about forty, and its circumference nearly fix hundred. There is a remarkable ftring of fmall iflands beginning over againft Afkins's farm, and running about thirty miles fouth-weft 


\section{( 26 )}

into the Lake. Thefe are called the Beaver Iflands. Their fituation is very pleafant, but the foil is bare. However they afford a beautiful profpect.

On the north-weft parts of this Lake the waters branch out into two Bays. That which lies towards the north is the Bay of Noquets, and the other the Green Bay juft defcribed.

The waters of this as well as the other great Lakes are clear and wholefome, and of fufficient depth for the inavigation of large fhips: Half the fpace of the country that lies to the eaft, and extends to Lake Huron, belongs to the Ottowaw Indians. The line that divides their territories from the Chipeways, runs nearly north and fouth, and reaches almoft from the fouthern extremity of this Lake, acrofs the high lands, to Michillimackinac, through the center of which it paffes. So that when thefe two tribes happen to meet at the factory, they each encamp on their own dominions, at a few yards diftance from the Atockade.

The country adjacent either to the eaft or weit fide of this Lake is compofed but of an indifferent foil, except where finall brooks or

rivers 
afant, ford a

e the

That

ay of juft

great

fuf-

arge

that

iron,

line

Chi-

and

nity

$\mathrm{Mi-}$

hich

pap-

$\mathrm{mp}$

dif-

or

an

or

ers

rivers empty thenifelves into it ; on the banks of thefe it is extremely fertile. Near the borders of the Lake grow a great number of fand cherries, which are not lefs remarkable for their manner of growth, than for their exquifite flavour. They grow upon a finall Mrub not more than four feet high, the boughs of which are fo loaded that they lie in clusters on the fand. As they grow only on the fand, the warmth of which probably contributes to bring them to fuch perfection, they are called by the French cerifes de fable, or fand cherries. The fize of them does not exceed that of a fmall munket ball, but they are reckoned fuperior to any other fort for the purpofe of fteeping in fpirits. There alfo grow around the Lake goofeberries, black currants, and an abundance of juniper, bearing great quantities of berries of the fineft fort.

Sumack likewife grows here in great plenty; the leaf of which, gathered at $\mathrm{Mi}$ chaelmas when it turns red, is much eftecmed by the natives. They mix about an equal quantity of it with their tobacco, which caufes it to fmoke pleafantly. Near this Lake, and indeed all the great lakes, is found a

kind 


\section{( 28$)$}

kind of willow, termed by the French, bois rouge, in Englifh red wood. Its bark, when only one year's growth, is of a fine fcarlet colour, and appears very beautiful; but as it grows older, it changes into a mixture of giey and red. The ftalks of this fhrub grow many of them together, and rife to the height of fix or eight feet, the largeft not exceeding an inch dian neter. The bark being. fcraped from the flicks, and dried and powdered, is alfo mixed by the Indians with their tobacco, and is held by them in the higheft eftimation for their winter fmoaking. A weed that grows near the great lakes, in rocky places, they ufe in the fummer feafon. It is called by the Indians, Segockimac, and creeps like a vine on the ground, fometimes extending to eight or ten feet, and bearing a leafabout the fize of a filver penny, nearly round; it is of the fubftance and colour of the laurel, and is, like the tree it refembles, an evergreen. Thefe leaves, dried and powdered, they likewife mix with their tobacso; and, as faid before, fmoak it only during the fummer. By thefe three fuccedaneums the pipes of the Indians are well fupplicd through every feafon of the ycar; 


\section{(29)}

year; and as they are great fmoakers, they are very careful in properly gathering and preparing thiem.

On the 2oth of September I left the Green Bay, and proceeded up Fox river, ftill in company with the traders and fome Indians. On the $25^{\text {th }} 1$ arrived at the great town of the Winnebagoes, fituated on a fmall ifland juft as you enter the eaft end of Lake Winnebagoe. Here the queen who prefided over this tribe inftead of a Sachen, received me; with great civility, and entertained me in a very diftinguifhed manner, during the four days I continued with her.

The day after my arrival I held a council with the chiefs, of whom I afked permiflion to pars through their country, in my way to more remote nations on bufinefs of importance. This was readily granted me, the requeft being efteemed by them as a great compliment paid to their tribe. The Queen fat in the council, but only afked a fow queftions, or gave fome trifling directions in matters relative to the ftate; for women are never allowed to fit in their councils, except they happen to be invefted with the fupreme authority, and then it is not cuftomary. for

them 


\section{(30)}

them to make any formal fpeeches as the chiefs do. she was a very ancient woman, fmall in ftature, and not much diftinguifhed by her drefs from feveral young women that attended her. Thefe her attendants feemed. greatly pleafed whenever I thowed any tokens of refpect to their queen, particularly when I faluted her, which I frequently did to acquire her favour. On thefe occafions the good old lady endeavoured to affume a juvenile gaiety, and by her fmiles thowed the was equally pleafed with the attention $I$ paid her.

The time I tarried here, I employed in making the beft obfervations poffible on the country, and in collecting the moft certain intelligence I could of the origin, language, and cuftoms of this people. From there enquiries I have reafon to conclude, that the Winnebagoes originally refided in fome of the provinces belonging to New Mexico; and being driven from their native country, either by inteftine divifions, or by the extenfion of the Spanifh conquetts, they took refuge in thefe more northern parts about a century ago.

My 


\section{(3I)}

the

My reafons for adopting this fuppofition, are, firft from their unalienable attachment to the Naudoweflie Indians (who, they fay, gave them the earlieft fuccour during their emigration) notwithftanding their prefent refidence is more than fix hundred miles diftant. from that people.

Secondly, that their dialect totally differs from every other Indian nation yet difcovered; it being a very uncouth guttural jargon, which none of their neighbours will attempt to learn. They converfe with other riations in the Chipeway tongue, which is the prevailing language througliout all the tribes, from the Mohawks of Canada to thofe who inhabit the borders of the Miffiffippi, and from the Hurons and Illinois to fuch as dwell near Hudfon's Bay.

Thirdly, from their inveterate hatred' to the Spaniards. Some of them informed me that they had made many excurfions to the fouth-weft, which took up feveral moons. An elderly chief more particularly acquainted me, that about forty-fix winters ago, he marched, at the head of fifty warriors, towards the fouth-weft, for three moons. That during this expedition, whilft they were croffing a plain, 


\section{( 32$)$}

a plain, they difcovered a body of men on horfeback, who belonged to the Black People; for fo they call the Spaniards. As foon as they perceived them, they proceeded with caution, and concealed themfelves till night came on; when they drew fo near as to be able to difcern the number and fituation of their enemies. Finding they were not able to cope with fo great a fuperiority by daylight, they waited till they had retired to reft; when they rumed upon them, and after having killed the greateft part of the men, took eighty horfes loaded with what they termed white ftone. This I fuppofe to have been filver, as he told me the horfes were fhod with it, and that their bridles were ornamented with the fame. When they had fatiated their revenge, they carried of their fpoil, and being got fo far as to be out of the reach of the Spaniards that had efcaped their fury, they left the ufelefs and ponderous bur. then, with which the horfes were loaded, in the woods, and mounting themfel ves, in this manner returned to their friends. The party they had thus defeated, I conclude to be the caravan that annually conveys to Mexico, the flver which the Spaniards find in great quantities 
n on

Peofoon with night to be on of able dayreft; havtook ermed been thod ornaid fatheir fo the their bur.. d, in 1 this party e the b, the uantities

\section{( 33 )}

tities on the mountains lying near the heads of the Coloredo River: and the plains where the attack was made, probably, fome they were obliged to pafs over in their way to the heads of the River St. Fee, or Rio del Nord, which falls into the gulph of Mexico to the weft of the Miffifippi.

The Winnebagoes can raife about two huidred warriors. Their town contains about fifty. houfes, which are. Arongly built with palifadoes, and the ifland on which it is fituated nearly fifty acres. It lies thirty-five miles, reckoning according to the courfe of the river, from the Green Bay.

The River, for about four or five miles from the Bay, has a gentle current; after that fpace, till you arrive at the $W$ innebago Lake, it is full of rocks and very rapid. At many places we were obliged to land our canoes, and carry them a confiderable way. Its breadth, in gencral, from the Green Bay to the Winnebago Lake, is between feventy and a hundred yards: the land on its borders very good, and thinly wooded with hickery, oak, and hazel.

The W:innebago Lake is about fifteen miles long from eaft to weft, and fix miles 


\section{( 34 )}

wide. At its fouth-weft corner a river falls into it that takes its rife near fome of the northern branches of the Illinois River. This I called the Crocodile River, in confequence of a ftory that prevails among the Indians, of their having deftroyed, in fome part of it, an animal, which from their defcription muft be a crocodile or an alligator.

The land adjacent to the Lake is very fertile, abounding with grapes, plumbs, and other fruits, which grow fpontaneoully. The Winnebagoes raife on it a great quantity of Indian corn, beans, pumpkins, fquarh, and water melons, with fome tobacco. The Lako itfelf abounds with fifh, and in the fall of the year, with geefe, ducks, and teal. The latter, which refort to it in great numbers, are remarkably.good and extremely fat, and are much better flavoured than thofe that are found near the fea, as they acquire their exceflive fatners by feeding on the wild rice, which grow fo plentifully in there parts.

Having made fome acceptable prefents to the good old queen, and received her bleffing, I left the town of the Winnebagors on the gth of September, and about twelve miles from it arrived at the place where the Fox 


\section{(35)}

falls:

River enters the Lake on the north fide of it. We proceeded up this river, and on the 7 th of October reached the great carrying Place, which divides it from the Ouifconfin.

The Fox River, from the Green Bay to the Carrying Place, is about one hundred and eighty miles. From the Winnebago Lake to the Carrying Place the current is gentle, and the depth of it confiderable; notwithftanding which, in fome places it is with difficulty that canoes can pafs, through the obftructions they meet with from the rice ftalks, which are very large and thick, and grow here in great abundance. The country around it is very fertile and proper in the higheft degree for cultivation, excepting in fome places near: the River, where it is rather too low. It is in no part very woody, and yet can fupply fufficient to anfwer the demands of any number of inhabitants. This river is the greateft refort for wild fowl of every kind that I met with in the whole courfe of my travels; frequently the fun would be obfcured by them for fome minutes together.

About forty miles up this river, from the great town of the Winnebagoes, ftands a finaller town belonging to that nation.

$\mathrm{D}_{2}$

Deer

ts to

fing,

the

miles

Fox River 


\section{( 36$)$}

Deer and bears are very numerous in thefe parts, and a great many beavers and other furs are taken on the ftreams that empty themfelves into this river.

The River I am treating of, is remarkable for having been, about eighty years ago, che refidence of the united bands of the Ottigaumies and the Saukies, whom the French had nicknamed, according to their wonted cuiftom, Des Sacs and Des Reynards, the Sacks and the Foxes, of whom the following anecdote was related to me by an Indian.

About fixty yearsago, the French mifionaries and traders having received many infults from thefe people, a party of French and Indians under the command of Captain Morand marched to revenge their wrongs. The captain fet out from the Green Bay in the winter, when they were unfufpicious of a vifit of this kind, and purfuing his route over the fnow to their villages, which lay about fifty miles up the Fox River, came upon them by furprize Unprepared as they were, he found them an eafy conqueft, and confequently killed or took prifoners the greateft part of them. On the return of the French to the Green Bay, one of the Indian chiefs 


\section{(37)}

hele ther

npty

rable

, the igau$x$ had curSacks anec-

ffiony inrench uptain ongs. ay in bus of route i lay e upthey , and $s$ the of the ndian chiefs chiefs in alliance with them, who had a confiderable band of the prifoners under his care, ftopped to drink at a brook; in the mean time his companions went on: which being obferved by one of the women whom they had made captive, the fuddenly feizert him with both her hands, whilft he ftooped to drink, byian exquifitely fufceptible part, and held him faft till he expired on the fpot As the chief, from the extreme torture he fuffered, was unable to call out to his friends, or to give any alarm, they paffed on without knowing what had happened; and the woman having cut the bands of thofe of her fellow-prifoners who were in the rear, with them made her efcape. This heroine was ever after treated by her nation as their deliverer, and made a chiefefs in her own right, with liberty to entail the fame honour on her defcendants : an unufual diftinction, and permitted only on extraordinary occafions.

About twelve miles before I reached the Carrying Place, I obferved feveral fmall mountains which extended quite to it. Thefe indeed would only be efteemed as molehills when compared with thofe on the back of the colonies, but as they were the firf I had

fcen 


\section{$\left(3^{8}\right)$}

feen fince my leaving Niagara, a track of nearly eleven hundred miles, I could not loave thein unnoticed.

The Fox River, where it enters the Winnebago Lake, is about fifty yards wide, but it gradually decreafes to the Carrying Place, where it is no more than five yards over, except in a few places where it widens into fmall lakes, though ftill of a confiderable depth. I cannot recolled any thing elfe that is remarkable in this River, except that it fo ferpentines for five miles, as only to gain in that place one quarter of a mile.

The Carrying Place between the Fox and Ouifconfin Rivers is in breadth not more than a mile and three quarters, though in fome mups it is fo delineated as to appear to be ten miles. And here I cannot help remarking, that all the maps of thefe parts, I have ever feen, are very erroneous. The rivers in general are defcribed as running in different directions from what they really do; and many branches of them, particularly of the Mififfippi, omitted. The diftances of places, likewife, are greatly mifreprefented. Whether this is done by the French geographers (for the Englim maps are all copied from theirs) 


\section{( 39 )}

theirs) through defign, or for want of a juft knowledge of the country, I cannot fay; but I am fatisfied that travellers who depend upon them in the parts I vifited, will find themfelves much at a lors. Having furveyed with the greateft care, every country through which 1 paffed, I can affert that the plan prefixed to this work is drawn with much greater precifion than any extant.

Near one half of the way, between the rivers is a morafs, over-grown with a kind of long grafs, the reft of it a plain, with fome few oak and pine trees growing thercon. I obferved here a great number of rattle-fnakes. Monf. Pinnifance, a French trader, told me a remarkable ftory concerning one of thefe reptiles, of which he faid he was an eye-witnefs. An Indian, belonging to the Menomonie nation, having taken one of them, found means to tame it; and when he had done this, treated it as a Deity; calling it his Great Father, and carrying it with him in a box wherever he went. This the Indian had done for feveral fummers, when Monf: Pinnifance accidentally met with him at this Carrying Place, juft as he was fetting off for a winter's hunt. The French gentleman was furprized, 


\section{( 40$)$}

furprized, one day, to fec the Indian place the box which contained his god on the ground, and opening the door give him his liberty; telling him, whilft he did it, to be fure and return by the time he himfelf fhould come back, which was to be in the month of May following. As this was but October, Monfieur told the Indian, whofe fimplicity aftonifhed him, that he fancied he might wait long enough when May arrived, for the arrival of his great father. The Indian was fo confident of his creature's obedience, that he offered to lay the Frenchman a wager of two gallons of rum, that at the time appointed he would come and crawl into his box. This was agreed on, and the fecond week in May following fixed for the determination of the wager. At that period they both met there again, when the Indian fet down his box, and called for his great father. The fnake heard him not, and the time being now expired, he acknowledged that he had loit: However, without feeming ito be difcouraged, he offered to double the tett if his great father came not within two days more. This was further agreed on; when behold on the fecond day, about one o'clock, the 


\section{(4I)}

the fnake arrived, of his own accotd, crawled into the box, which was placed ready for him. The French gentleman vouched for the truth of this ftory, and from the accounts I have often received of the docility of thofe creatures, I fee no reafon to doubt his veracity.

I obferved that the main body of the Fox River came from the fouth-weft, that of the Ouifconfin from the north-eaft; and alfo that fome of the fmall branches of thefe two rivers, in defcending into them, doubled within a few feet of each other, a little to the fouth of the Carrying Place. That two fuch Rivers fhould take their rife fo near each other, and after running fuch different courfes, empty themfelves into the fea at a diftance fo amazing (for the former having paffed through feveral great lakes, and run upwards of two thoufand miles, falls into the gulph of St. Lawrence, and the other, after joining the Miffiflippi; and running an equal number of miles, difembogues itfelf into the Gulph of Mexico) is an inftance fcarcely to I be met in the extenfive continent of North America. I had an opportunity the year following, of making the fame obfervations 


\section{$(42)$}

on the alfinity of various head branches of the waters of the St. Jawrence and the Miffifi!pi to each other; and now bring them as a proof, that the opinion of thofe geographers, who afert, that rivers taking their rife fo near each other, muft fpring from the fame rource, is erroneous. For I perceived a vifibly diftinet feparation in all of them, notwithftanding, in fome places, they approached fo near, that I could have ftepped from one to the other.

On the 8th of OEtober we got our canoes intc the Ouifconfin River, which at this place is more than an hundred yards wide; and the next day arrived at the Great Town of the Saukies. This is the largeft and beft built Indian town I ever faw. It contains about ninety houfes, each large enough for feveral families. Thefe are buili, of hewn plank neatly jointed, and covered with bark fo compactly as to izeep out the molt penetrating rains. Before the doors are placed coinfortahle fheds, in which the inhabitants fit, when the weather will permit, and fmoak their pipes. The ftreets are regular and fpacious; fo that it appears more like a civilized. town than the abode of favages. The land 


\section{( 43 )}

near the town is very good. In their plantations, which lie adjacent to their houfes, and which are neatly laid out, they raife great quantities of Indian corn, beans, melons, \&c. fo that this place is efteemed the beft market for traders to furnifh themfelves with provifions, of any within eight hundred miles of it.

The Saukies can raife about three hundred warriors, who are generally employed every fummer in making incurfions into the territories of the Illinois and Pawnee nations, from whence they return with" a gieat number of flaves. But thofe people frequently retaliate, and, in their turn, deftroy many of the Saukies, which I judge to be the reafon that they increafe no fafter.

Whilf I ftaid here; I took a view of fome mountains that lie about fifteen miles to the fouthward, and abound in lead ore. I afcended one of the higheft of thefe, and had an extenfive view of the country. For many miles nothing was to be feen but leffer mountains, which appeared at a diftance like haycocks, they being free from trees. Only a few groves of hickery, and ftunted oaks, covered fome of the vallies. So plentiful is 


\section{( 44 )}

lead heis, that I faw large quantities of it lying about the ftreets in the town belonging to the Saukies, and it feemed to be as good as the produce of other countries.

On the roth of October we proceeded down the river, and the next day reached the firft town of the Ottigaumies. This town contained about fifty houres, but we Ifound moft of them deferted, on account of an epidemical diforder that had lately raged among them, and carried off more than one half of the inhabitants. The greater part of thofe who furvived had retired into woods to avoid the contagion.

* On the I $5^{\text {th }}$ we entered that extenfive river the Miffiffippi. The Ouifonfin, from the Carrying Place to the part where it falls into the Miffifippi, flows with a fmooth a Atrong current; the water of it is exceeciingly clear, and through it you may perceive a fine and fandy bottom, tolerably free from rocks. In it are a few inlands, the foil of which appeared to be good, though fomewhat woody. The land near the river alfo feemed to be, in general, excellent; but that at a diftance is very full of mountains, where it is faid there are many lead mines. 


\section{( 45 )}

of it

nging

grod

eeded

ached

\section{This}

ut we

unt of

raged

n one

$r$ part into

enfive

from

it falls

th $\mathrm{c}$

xceeci-

per-

erably

, the

hough

river

llent;

houn-

lead

About

About five miles from the junction of the rivers, I obferved the ruins of a large town in a very pleafing fituation. On enquiring of the neighbouring Indians why it was thus deferted, I was informed that about thirty years ago, the Great Spirit had appeared on the top of a pyramid of rocks, which lay at a little diftance from it, towards the weft, and warned them to quit their habitations; for the land on which they were built belonged to him, and he had occafion for it. As a proof that he, who gave them thefe orders, was really the Great Spicit, he further told them, that the grafs Mould immediately fpring up on thofe very rocks from whence he now addreffed them, which they knew to be bare and barren. The Indians obeyed, and foon after difcovered that this miraculous alteration had taken place. They thewed me the fpot, but the growth of the grafs appeared to be no ways fupernatural. I apprehended this to have been a ftratagem of the French or Spaniards to anfwer fome felfirh view, but in what manner they effected their purpofes I know not.

This people, foon after their removal, built a town on the bank of the Miffifippi, near the 


\section{('46.)}

the mouth of the Ouifconfin, at a place called by the French La Prairies les Chiens, which fignifies the Dog Plains; it is a large town, and contains about three hundred $\mathrm{fa}$ milies, the houfes are well built after the Indian manner, and pleafantly fituated on a very rich foil, from which they raife every neceffary of life in great abundance I faw here many horfes of a good fize and thape. This town is the great mart, where all the adjacent tribes, and even thofe who inhabit the mont remote branches of the Miffifippi; annually affemble about the latter end of May bringing with them their furs to difpofe of to the traders. But it is not al ways that they conclude their fale here; this is determined by a general council of the chiefs, who confult whether it would be more conducive to their intereft, to fell their goods at this place, or carry them on to Louifiana, or $\mathrm{Mi}$ chillimackinac. According to the decifion of this council they either proceed further, or return to their different homes.

The Mififfippi at the entrance of the Ouifconfin, near which ftands a mountain of confiderable height, is about half a mile o: ver; but oppofite to the laft mentioned town. 


\section{(. 47$)$}

slace

iens,

large

fa.

the

on a

very

faw

rape.

the

habit

Tippi;

May

fe of

they

ined

con-

acive

this

$\mathrm{Mi}$ -

n of

or

the

$\mathrm{n}$ of

$0=$

bwn.

it appears to be more than a mile wide; and full of iflands, the foil of which is extraordinarily rich, and but thinly wooded.

A little farther to the weit, on the contrary fide, a fmall river falls into the Miffiffippi, which the French call Le Jaun Riviere, or the Yellow River. Here the traders who had accompanied me hitherto, took up their refidence for the winter. I then bought a canoe, and with two fervants, one a French Canadian and the other a Mohawk of Canada, on the igth proceeded up the Miffiflippi.

About ten days after I had parted from the traders, I landed as I ufually did every evening, and having pitched my tent, 1 ordered my men, when night came on, to lay themfelves down to fleep. By a light that I kept burning I then fat down to copy the minutes I had taken in the courfe of the preceding day. About ten o'clock having juft finifhed my memorandums, I ftepped ont of my tent to fee what weather it was. As I caft my eyes towards the bank of the river, I thought I faw by the light of the fars which fhone bright, fomething that had the appearance of a herd of beafts coming down

a defcent 


\section{(. 48$)$}

a defcent at fome diftance; whilft I was wondering what they could be, one of the number fuddenly fprung up and difcovered to me the form of a man. In an inftant they were all on their legs, and I could count about ten or twelve of them runining towards me. I immediately re-entered the tent, and awaking my men, ordered them to take their arms, and follow me. As my firt apprehenfions were for my canoe, I ran to the water's fide, and found a party of Indians (for fuch I now difcovered them to be) on the point of plundering it. Before I reached them I commanded iny men not to fire till I had given the word, being unwilling to begin hoftilities unlefs occafion abfolutely required. I accordingly advanced with refolution, clofe to the points of their fpears, they had no other weapons, and brandilhing my hanger, ked them with a ftern voice, what they wanted. They were ftaggered at this, and perceiving they were like to meet a warm reception, turned about and precipitately retreated. We purfued them to an adjacent wood, which they entered, and we faw no more of them. However, for fear of their return, we watched alternately during 


\section{( 49 )}

ing the remainder of the night. : The next day my fervants were under great apprehenfions, and earneftly entreated me to return to the traders we had lately left. But I told them, that if they would not be efteemed old women (a term of the greateft reproach among the Indians) they muitt follow me; for I was determined to purfue my intended route, as an Englifhman, when onfe engaged in an adventure, never retreated. On this they got into the canoe, and I walked on the thore to guard them from any further attack. The party of Indians who had thus intended to plunder me, I afterwards found to be fome of thofe ftraggling bands, that having been driven from among the different tribes to which they belonged for various crimes, now affociated themfelves together and living by plunder, prove very troublefome to travellers who pafs this way; nor are even Indians of every tribe pared by them. The traders had before cautiuned me to be upon my guard againft them, and I would repeat the fame caution to thofe whofe bufinefs might call them into thefe parts.

E

On 


\section{( 50$)$}

On the firft of November, I arrived at Lake Pepin, which is rather an extended part of the River.Mififfippi, that the French have thus denominated, about two hundred miles from the Ouifconfin. The Miffiffippi below this lake flows with a gentle current, but the breadth of it is very uncertain, in. fome places it being upwards of a mile, in others not more than a quarter. This $\mathrm{Ri}$ ver has a range of mountains on each fide throughout the whole of the way; which in particular parts approach near to it, in others lie at a greater diftance. The land betwixt the mountains, and on their fides, is generally covered with grafs with a few groves of trees interfperfed, near which large droves of deer and clk are frequently feen feeding. In many places pyramids of rocks appear, refembling old ruinous towers; at others amazing precipices: and what is very remarkable, whillt this fcene prefented itfelf on one fide, the oppofite fide of the fame mountain was covered with the fineft herbage, which gradually afcended to its fummit. From thence the molt beautiful and extenfive profpect that imagination can form opens to your view. Verdant plains, fruitful meadows, pumerous iflands, and all thefe abounding 


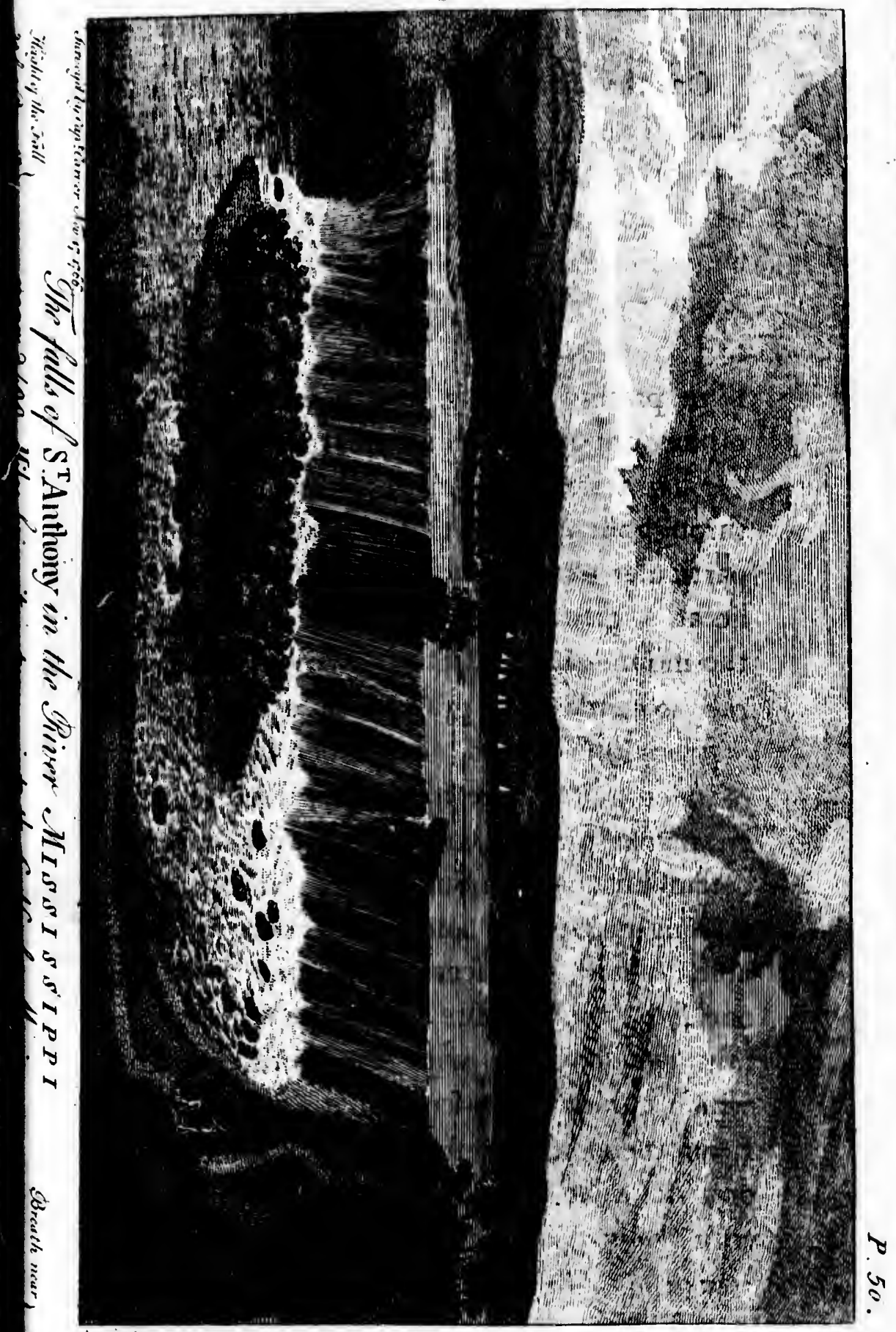




\section{( $\left.5^{I}\right)$}

ing with a variety of trees that yield amazing quantitics of fruit, without care or cultivation, fuch as the nut-tree, the maple which produces fugar, vines loaded with rich grapes, and plumb-trees bending under their blooming burdens, but above all, the fine River flowing gently beneath and reaching as far as the eye can extend, by turns attract your admiration and excite your wonder.

The Lake is about twenty miles long and near fix in breadth; in fome places it is very deep, and abounds with various kinds of filh. Great numbers of fowl frequent alfo this Lake and rivers adjacent, fuch as ftorks, fwans, geefe, brants, and ducks : and in the groves are found great plenty of turkeys and partridges. On the plains are the largeft buffaloes of any in America: Here I obferved the ruins of a French factory, where it is faid Captain St. Pierre refided, and carried on a very great tradé with the Naudoweffies, before the reduction of Canada.

About fixty miles below this Lake is a mountain remarkably fituated; for it ftands by itfelf exactly in the middle of the River, and looks as if it had nidden from the adjacent thore into the ftream. It cannot be E 2 termed 


\section{$(52)$}

termed an inland, as it rifes immediately from the brink of the water to a confiderable height. Both the Indians and the French call it the Mountain in the river.

One day having landed on the thore of the Miffffippi, fome miles below Lake Pepin, whilf my attendants were preparing my dinncr, I walked out to take a view of the adjacent country. I had not proceeded far, bcfore I came to a fine, level, open plain, on which I perceived, at a little diftance, a partial elevation that had the appearance of an intrenchiment. On a nearer infpection I had greater reafon to fuppofe that it had really been intended for this many centuries ago. Notwithftanding it was now covered with grafs, I could plainly difcern that it had once been a breaft-work of about four feet in height, extending the beft part of a mile, and fufficiently capacious to cover five thoufand men. Its form was fomewhat circular, and its flanks reached to the River. Though much defaced by time, every angle was diftinguirhable, and appeared as regular, and famioned with as niuch military nill, as if planned by Vauban himfelf. The ditch was not vifible, but $I$ thought on examining more curioufly, 


\section{( 53 )}

curiounly, that I could perceive there certainly had been one. From its fituation alfo, I am convinced that it muft have been defigned for this purpole. It fronted the country, and the rear was covered with the river; nor was there any rifing ground for a coniderable way that commanded it; a. few Araggling oaks were alone to be feen near it. In many places fmall tracks, were worn acrofs it by the feet of the elks and deer, and from the depth of the bed of earth by which it was covered, I was able to draw certain conclufions of its great antiquity. I examined all the angles and every part with great attention, and have often blamed nyfelf fince, for not encamping on the fpot, and drawing an exact plan of it. To hew that this defcription is not the offspring of a heated imagination, or the chimerical tale of a miftaken traveller, I find on enquiry fince my return, that Monf. St. Pierre and feveral traders have, at different times, taken notice of fimilar appearances, on which they have formed the fame conjectures, but without examining them fo minutely as I did. How a. work of this kind could exift in a country that has hithorto (according to the general 


\section{( 54$)$}

received opinion) been the feat of war to untutored Indians alone, whore whole ftock of military knowledge has only, till within two centuries, amounted to drawing the bow, and whofe only breaft-work even at prefent is the thicket, I know not. I have given as exact an account as poffible of this fingular appearance, and leave to future explorers of thefe diftant regions to difcover whether it is a production of nature or art. Perhaps the hinits $I$ have here given might lead to a more perfect invertigation of it, and give us very different ideas of the ancient ftate of realms th the at prefent believe to have been from the earlieft period only the habitations of favages.

The Miffifippi, as far as the entrance of the river St. Croix, thirty miles above Lake Pepin, is very full of inlands; fome of which are of a confiderable length. On thefe, alfo, grow great numbers of the maple or fugar tree, and around them vines loaded with grapes creeping to their very tops. Fro:n the Lake upwards few mountains are to be feen, and thofe but fmall. Near the Rive: St. Croix refide three bands 


\section{( 55)}

uf the Nawdoweffie Indians, called the River Bands.

This nation is compofed, at prefent, of eleven bands. They were originally twelve; but the Affinipoils fome years ago revolting, and feparating themfelves from the others, there remained only at this time eleven: Thofe I met here are termed the River Bands; becaufe they chiefly dwell near the banks of this River: the onher eight are generally diftinguined by the title of the Naudowefties of the Plains, and inhabit a country that lies more to the weftward. The names of the former are the Nchogatawonahs, the Mawtawbauntowahs, and the Shahifweentowahs, and confift of about four hundred warriors.

A little before I met with thefe three bands I fell in with a party of the Mawtawbauntowahs, amounting to forty warriors and their families. With thefe I refided a day or two, during which time five or fix of their number, who had been out on an cxcurfion, returned in great hafte, and acquainted their companions that a large party of the Chipeway warriors, " enough," as they expreired themfelves, "to fwallow them 


\section{( $\left.5^{6}\right)$}

all up," were clofe at their heels, and on the point of attacking their little camp. The chiefs applied to me, and defired I would put myfelf at their head, and lead them out to oppofe their enemies. As I was a ftranger, and unwilling to excite the anger of either nation, I knew not how to act; and never found myfelf in a greater dilemma. Had I refufed to affift the Naudoweffies I I Thould have drawn on myfelf their difpleafure, or had I met the Chipeways with hortile intentions, I hould have made that people my focs, and had I becn fortunate enough to have cfcaped their arrows at this time, on fome future occation I thould probably have experienced the feverity of their revenge. In this extremity I chofe the middle courfe, and defired that the Naudoweffies would fuffer me to meet then, that I might endeavour to avert their fury. To this they reluciantly affented, being perfuaded, from the inveteracy which had long prevailed between them, that my remonftrances would be vain.

'Taking my Frenchman with me, who could fpeak their language, I haftened towards the place where the Chipeways were fuppofed 


\section{( 57 )}

fuppofed to be. The Naudoweffies during this kept at a diftance behind. As I approached the:n with the pipe of peace, a fmall party of their chiefs, confifting of about eight or ten, came in a friendly manner towards me; with whom, by means of my interpreter, I held a long converfation; the refult of which was, that their rancour being by my perfuafions in forre meafure mollified, they agreed to return back without accomplifhing their favage purpofes. During our difcourfe I could perceive as they lay fcattered about, that the party was very nu- . merous, and many of them armed with murkets.

Having happily fucceeded in my undertaking, I returned without delay to the Naudoweflies, and defired they would inftantly remove their camp to fome other part of the country, left their enemies hould repent of the promife they had given, and put their intentions into execution. They accordingly followed my advice, and imınediately prepared to ftrike their tents. Whillt they were doing this they loaded me with thanks; and when I had feen them on board their cunces I purfued my route. 


\section{$\left(5^{8}\right)$}

To this adventure I was chiefly indebted for the friendly reception I afterwards met with from the Naudoweffies of the Plains, and for the refpect and honours I received during my abode among them. And when $I$ arrived many months after at the Chiptway village, near the Ottowaw lakes, I found that my fame had reached that place before me. The chiefs received me with great cor diality, and the elder part of them thanked me for the mifchief I had prevented. They informed me, that the war between their natica and the Naudoweffies had continued without interruption for more than forty winters. 'That they had long wimed to put an end to it, but this was generally prevented by the young warriors of either nation, who could not reftrain their ardour when they met. They faid, they fhould be happy if fome chief of the fame pacific difpofition as myfelf, and who poffeffed an equal degree of refolution and coolnefs, would fettle: in the country between the two nations; for: by the interference of fuch a perfon an accommodation, which on their parts they fin-. serely defired, might be brought about. As I did not meet any of the Naudoweffies af-

terwards, 


\section{( 59 )}

terwards, I had not an opportunity of forwarding fo good a work.

About thirty miles below the Falls of St. Anthony, at which I arrived the tenth day after I left Lake Pepin, is a remarkable cave of an amazing depth. The Indians term it Wakon-teebe, that is, the Dwelling of the Great Spirit. The entrance into it is about ten feet wide, the height of it five feet. The arch within is near fifteen feet high and about thirty feet broad. The bottom of it confils of fine clear fand. About twenty feet from the entrance begins a lake, the water of which is tranfparent, and extends to an unfearcilable diftance; for the darknefs of the cave prevents all attempts to acquire a knowledge of it. I threw a fmall pebble towards the interior parts of it with my utmoft ftrength: I could hear that it fell into the water, and notwithftanding it was of fo fmall a fize, it caufed an aftonifhing and horsible noife that reverberated through all thofe glnomy regions. I found in this cave many Indian hieroglyphicks, which appeared very. ancient, for time had nearly covered them with mols, fo that it was with diffculty. I cculd trace them. They were cut in a rude 


\section{$(60)$}

manner upon the infide of the walls, which were compofed of a ftone fo extremely foft that it might be eafily penetrated with a knife: a ftone every where to be found near. the Miffifippi. The cave is only acceffible by afcending a narrow, Ateep paffage that lies near the brink of the river.

At a little diftance from this dreary cavern is the burying-place of feveral bands of the Naudoweffie Indians: though thefe people have no fixed refidence, living in tents, and abiding but a few months on one fpot, yet they always bring the bones of their dead to this place; which they take the opportunity of doing when the chiefs meet to hold their councils, and to fettle sll public affairs for the enfuing fummer.

- Ten miles below the Falls of St. Anthony the River St. Pierre, called by the natives the Wadapawmenefotor, falls into the Miffirfipi from the weft. It is not mentioned by Father Hennipin, although a large fair river: this omiffion, I conclude, muft have proceeded from a fmall ifland that is fituated exactly at its entrance, by which the fight of it is intercepted. I mould not have difcovered this river myfelf, had I not taken a view, when 


\section{(6r)}

when I was fearching for it, from the high lands oppofite, which rife to a great height.

Nearly over-againft this river I was obliged to leave my canoe, on account of the ice, and travel by land to the Falls of St. Anthony, where I arrived on the I $7^{\text {th }}$ of November. The Miffiffippi from the St. Pierre to this place is rather more rapid than I had hitherto found it, and without iflands of any confideration.

3. Before I left my canoe I overtook a,young prince of the Winnetago Indians, who was going on an embaffy to fome of the bands of the Naudoweffies. Finding that $I$ intended to take a view of the Falls, he agreed to accompany me, his curiofity having been often excited by the accounts he had received from fome of his chiefs: he accordingly left his family (for the Indians never travel without their houfholds) at this place, under the care of my Mohawk fervant, and we proceeded together by land, attended only by my-Frenchman, to this celcbrated place.

We could diftinctly hear the noife of the water full fiften miles before we reached the falls; and I was grcatly pleafed and furprized when I approached this aftonining work of nature : 


\section{( 62 )}

nature: but I was not long at liberty to indulge there emotions, my attention being called off by the behaviour of my companion.

The prince had no fooner gained the point that overlooks this wonderful cafcade, than he began with an audible voice to addrefs the Great Spirit, one of whofe places of refidence he imagined this to be. He told him that he had come a long way to pay his adoration to him, and now would make him the beft offerings in his power. He accordingly firf threw his pipe into the ftream; then the roll that contained his tobacco; after thefe, the bracelets he wore on his arms and writs; next an ornament that encircled his neck, compofed of beads and wires; and at laft the ear-rings from his ears; in fhort, he prefented to his god every part of his drers that was valuable; during this he frequently fmote his breaft with great violence, threw his arms about, and appeared to be much agitated.

All this while he continued his adorations, and at length concluded them with fervent petitions that the Great Spirit would confantly afford us his protection on our travels giving us a bright fun, a blue llyy, and clear .........

untroubled 


\section{(. 63 )}

untroubled waters; nor would he leave the place till we had fmoaked together with my pipe in honour of the Great Spirit.

I was greatly furprized at beholding an inftance of fuch elevated devotion in fo young an Indian, and inftead of ridiculing the ceremonies attending it, as $\mathrm{I}$ obferved my catholic fervant tacitly did, I looked on the prince with a greater degree of refpect for therefincere proofs he gave of his picty; and 1 doubt not but that his offerings and prayers were as acceptable to the univerfal Parent of mankind, as if they had been made with greater pomp, or in a confecrated place.

Indeed the whole conduct of this young prince at once amazed and charmed me. During the few days we were together his attention feemed totally to be employed in yielding me every affiftance in his power; and even in fo thort a time he gave me innumerable proofs of the moft generous and difinterefted friendhip; fo that on our return I parted from him with great reluctance. Whilf I beheld the artlefs, yet engaging manners of this unpolifhed favage, 1 could not help drawing a comparifon between him and fome of the more refined inhabitancs of ci- 


\section{(64)}

vilized countrics, not much, I own, in favour of the latter.

The Falls of St. Anthpny received their name from Father Louis Hennipin, a French miffionary, who travelled into thofe parts about the year $\mathrm{I} 680$, and was the firft European ever feen by the natives. This amazing body of waters, which are above $25^{\circ}$ yards over, form a moft pleafing cataract; they fall perpendicularly about thirty feet, and the rapids below, in the fpace of 300 yards more, renderel the defcent confiderably greater; fo that when viewed at a diftance they appear to be much higher than they really are. 'The above-mentioned traveller has laid them down at about fixty feet; but he has made a greater crror in calculating the height of the Falls of Niagara; which he afferts to be 600 fcet; whereas from latter obfervations accurately made, it - is : well known that it does not exceed I 40 feet. But the good father I fear too often had no other foundation for his accounts than report, $q r$ at beft, Aight infpection.

In the middla of the Falls ftands a finall ifland, about forty feet broad and fomewhat longer ${ }_{1}$ on which grow, a few cregged hemF lock 


\section{(65)}

lock and fpruce trees; and about half way between this ifland and the eaftern fhore, is a rock, lying at the very edge of the fall; in an oblique pofition; that appeared to be about five or fix feet broad, and thirty or forty long. Thefe falls vary much from all the others I have feen, as you may approach clofe to them without finding the leaft obftruction from any intervening hill or precipice.

The country around them is extremely beautiful. It is not an uninterrupted plain where the eye finds no relief, but compofed of many gentle afcents, which in the fummer are covered with the fineft verdure, and interfperfed with little groves, that give a plearing variety to the profpent. On the whole, when the Falls are included, which may be feen at the diftance of four miles, a more pleafing and picturefque view cannot, I believe, be found throughout the univerfe. I could have wifhed that I had happened to enjoy this glorious fight at a more feafonable time of the year, whilft the trees and hillocks were clad in nature's gayeft livery, as this mutt have greatly added to the pleafure I received; however, even then it ex- 


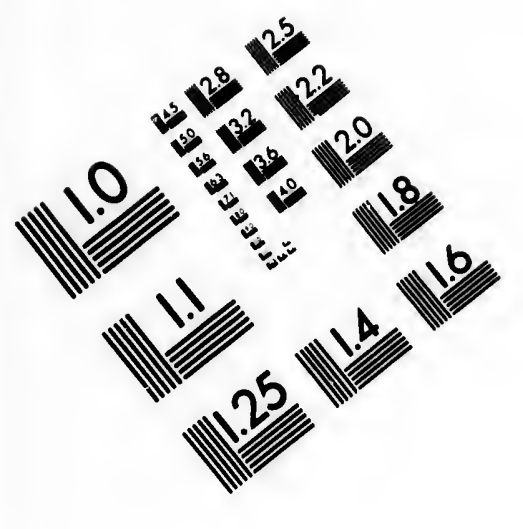

\section{IMAGE EVALUATION TEST TARGET (MT-3)}
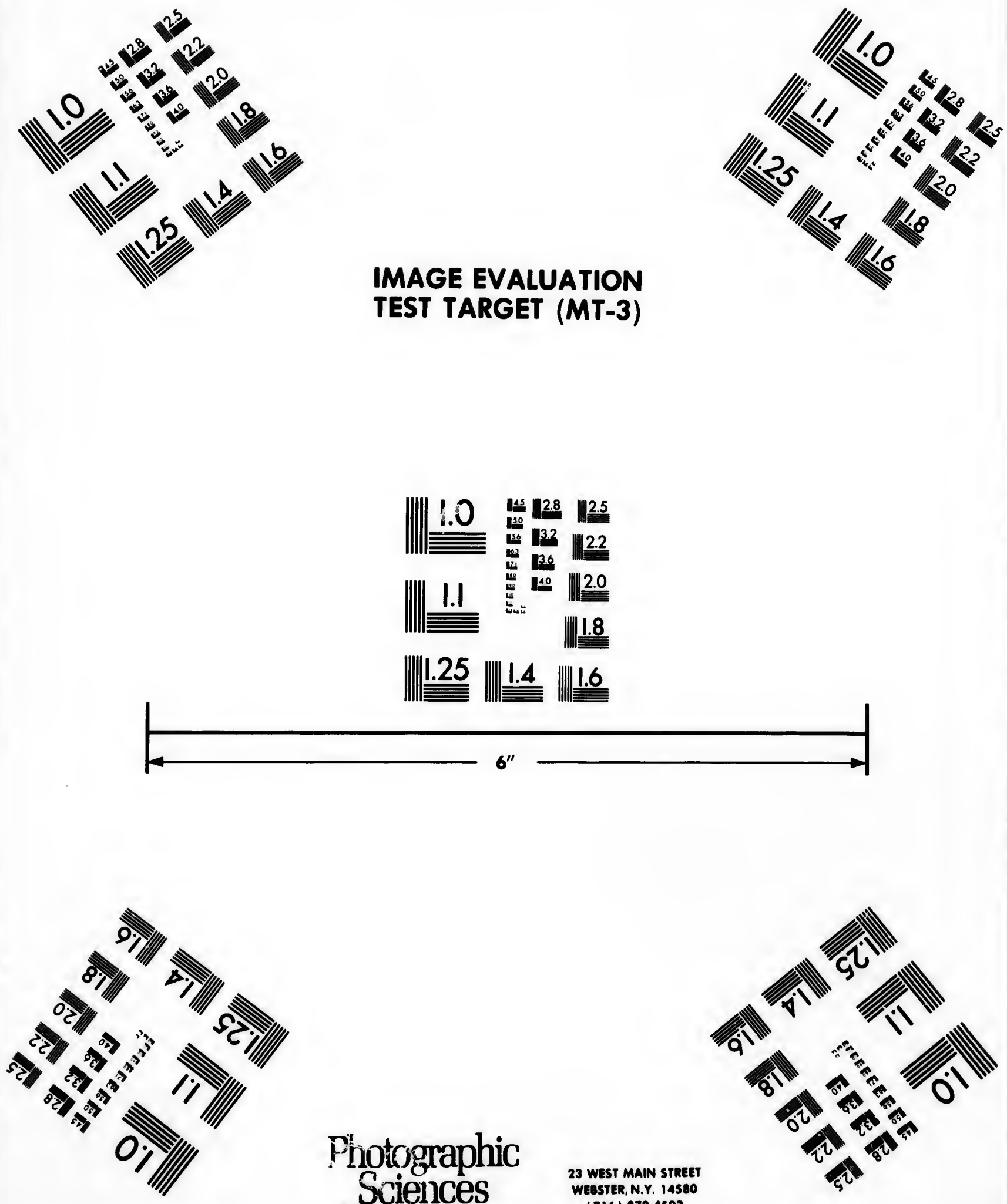

Photographic Sciences Corporation
23 WEST MAIN STREET WEBSTER, N.Y. 14580 (716) 872.4503

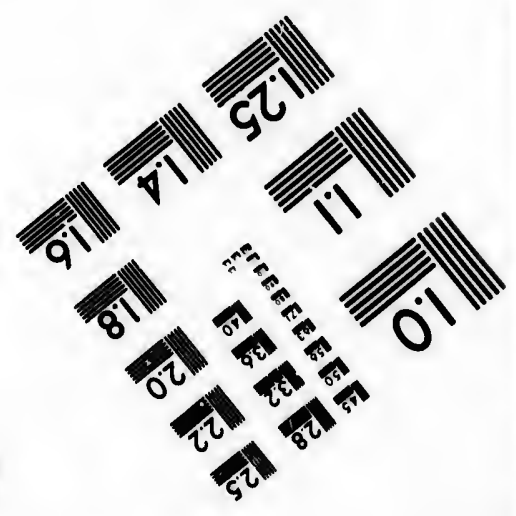





\section{( 66 )}

ceeded my warmeft expectations. I have endeavoured to give the reader as jult an idea of this enchanting fpot as poffible, in the plan annexed; but all defcription, whether of the pencil or the pen, muft fall infinitely fhort of the original.

At a little diftance below the falls ftands a finall ifland, of about an acre and half, on which grow a great number of oak trees, every branch of which, able to fupport the weight, was full of eagles nefts. The reafon that this kind of birds refort in fuch numbers to this fpot, is that they are here fecure from the attacks either of man or beaft, their retreat being guarded by the Rapids, which the Indians never attempt to pars. Another reafon is, that they find a conftant fupply of food for themfelves and their young, from the animals and filh which are danhed to pieces by the falls, and driven on the adjacent hore.

Having fatisfied my curiofity, as far as the eye of man can be futisfied, 1 proceeded on, Atill accompanied by my young friend, till I had reached the River St. Francis, near fixty miles above the Falls. To this River father Hennipin gave the name of St. Francis, and this 


\section{$(67)$}

this was the extent of his travels, as well as mine, towards the north-weft. As the feafon was fo advanced, and the weather extremely cold, I was not able to make fo many obfervations on thefe parts as I otherwife fhould have done.

It might however, perhaps, be neceffary to obferve, that in a little tour I made about the Falls, after travelling fourteen miles, by the fide of the Miffiflippi, I came to a river nearly twenty yards wide, which ran from the north-eaft, called Rum River. And on the 2oth of November came to another termed Goofe River, about twelve yards wide. On the 2 Ift I arrived at the St. Francis, which is about thirty yards wide. Here the Miffiflippi itfelf grows narrow, being not more than ninety yards over; and appears to be chiefly compofed of fmall branches. The ice prevented me from noticing the depth of any of thefe three rivers.

The country in fome places is hilly, but without large mountains; and the land is tolerably good. - I obferved here many deer, and carraboes, fome elk, with abundance of beavers, otters, and other furs. A little above this, to the north-eaft, are a number

$$
\mathrm{F}_{2}
$$




\section{(.68)}

of fmall lakes, called the Thoufand lakes; the parts about which, though but little frequented, are the beft within many miles for hunting, as the hunter never fails of returning loaded beyond his expectations.

The Miffiffippi has never been explored higher up than the River St. Francis, and only by Father Hennipin and myfelf thus far. So that we are obliged folely to the Indians, for all the intelligence we are able to give relative to the more northern parts. As this River is not navigable from the fea for veffels of any confiderable burthen, much higher up than the Forks of the Ohio, and even that is accomplifhed with great difficulty, owing to the rapidity of the current, and the winding of the river, thofe fettlements that may be made on the interior branches of it, muft be indifputably fecure from the attacks of any maritime power. But at the fame time the fettlers will have the advantage of being able to convey their produce to the fea-ports with great facility, the current of the river, from its fource to - its entrance into the Gulph of Mexico, being extremely favourable for doing this in f.nall craft. This might alfo in time be facili- 


\section{( 69 ( $)$}

tated by canals or Morter cuts; and a communication opened by water with New-York, Canada, \&c. by way of the lakes. The Forks of the Ohio are about nine hundred miles from the mo: ith of the Miffiffippi, following the courfe of the river; and the Mefforie two hundred miles above thefe. From the latter it is about twenty miles to the Illinois river, and from that to the $\mathrm{Ou}$ ifconfin, which I have given an account of, about eight hundred more.

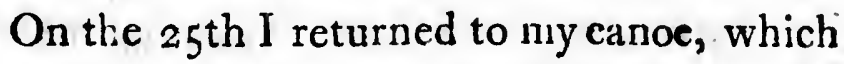
I had left at the mouth of the River St. Pierre; and here $I$ parted with regret from my young friend the prince of the Winnebagoes. This river being clear of ice by reafon of its fouthern fituation, I found nothing to obftruat my paffage. On the 28th, being advanced about forty miles, I arrived at a finall branch that fell into it from the north; to which, as it had no name that I could diftinguifh it by, I gave my own; and the Reader will find it in the plan of my travels denominated Carver's River. About forty miles higher up I came to the Forks of Verd and Red Marble Rivers, which joir it fome little diffance before they enter the St. Pierre. 


\section{( 70$)$}

The River St. Pierre, at its junction with the Miffiflippi, is about a hundred yards broad, and continucs that breadth nearly all the way I failed upon it. It has a great depth of water, and in fome places runs very brifkly. About fifty miles from its mouth are fome rapids, and much higher up there are many others.

I proceeded up this river about two hundred miles to the country of the Naudowerfies of the Plains, which lies a little above the Forks formed by the Verd and Red Marble Rivers, juft mentioned, where a branch from the fouth nearly joins the Merforie River. By the accounts I received from the Indians, I have reafon to believe that the River St. Pierre and the Mefforie, though they enter the Miffiffippi twelve hundred miles from each other, take their rife in the fame neighbourhood; and this within the fpace of a mile. The River St. Pierre's northern branch rifes from a number of lakes near the Mining mountains; and it is from fome of thefe, alfo, that a capital branch of the River Bourbon, which runs into Hudfon's Bay, has its fources. 


\section{( 71$)$}

From the intelligence I gained from the Naudoweffie Indians, among whom I arrived the $7^{\text {th }}$ of December, and whofe languagr I perfectly acquired during a refidence of feven months; and alfo from the accounts I afterwards obtained from the Affinipoils, who fpeak the fame tongue, being a revolted band of the Naudoweffies; and from the Killiftinoes, neighbours of the Affinipoils, who fpeak the Chipéway language, and inhabit the heads of the River Bourbon; I fay, from thefe nations, together with my own obfervations, I have learned that the four moft capital rivers on the Continent of North America, viz. the St. Lawrence, the Miffiffippi, the River Bourbon, and the Oregon or the River of the Weft (as I hinted in my Introduction) have their fources in the fame neighbourhood. The waters of the three former are, within thirty miles of each other; the latter, however, is rather farther. weft.

This thows that thefe parts are the higheft lands in Nurth America; and it is an inftance not to be paralleled on the other threc quarters of the globe, that four vivers of fuch magnitude fhould take their rife together, 


\section{( 72$)$}

and each, after running feparate courfes, difcharge their waters into, different oceans at the diftance of two thoufand miles from their fources. For in their paffage from this fpot to the bay of St. Lawrence, eaft, to the bay of Mexico, fouth, to Hudfon's Bay, north, and to the bay at the ftreights of $\mathrm{An}$ nian, weft, each of thefe traverfe upwards of two thoufand miles.

I hall here give my Readers fuch reflections as occurred to me when $I$ had received this interefting information, and had, by numberlefs inquiries, afcertained the truth of it; that is, as far as it was poffible to arrive at a certainty without a perfonal inveftigation.

It is well known that the Colonies, particularly thofe of New. England and Canada, are greatly affected, about the time their winter fets in, by a north-weft wind, which continues for feveral months, and renders the cold much more intenfe there, than it is in the interior parts of America. This I can, from my own knowledge, affert, as I found the winter, that I paffed to the weftward of $\because$ the Miffiffippi, far from fevere; and the north-weft wind blowing on thofe countries confiderably 


\section{$(73)$}

confiderably more temperate than I have often experienced it to be nearer the coaft. And that this did not arife from any uncertainty of the feafons, but was annually the cafe, I concluded, both from the fmall quantity of fnow that then fell, and a total difufe of fnow thoes by thefe Indians, without which none of the more eaftern nations can poffibly travel during the wintcr.

As naturalifts obferve, that air refembles water in many refpects, particularly by often flowing in a compact body; and that this is generally remarked to be with the current of large ftreams, and feldom acrofs them, may not the winds that fet violently into the Bay of Mexico about the latter end of the year, take their courfe over the continent in the fame direction as the Miffiffippi does; till meeting with the north winds (that from a fimilar caufe blow up the Bourbon from Hudfon's Bayl they are forced acrofs the great lakes, down the current of the waters of the St. Lawrence, and united, commit thofe ravages, and occafion thofe fevere winters, experienced in the before mentioned countries? During their progrefs over the lakes they become expanded, and confequently affect

a greater 


\section{( 74 )}

a greater tract of land than they otherwife would do.

According to my feanty knowledge of natural philofophy this does not appear improbable. Whether it is agreeable to the laws eftablifhed by naturalifts to account for the operations of that element, 'I know not. However, the defcription here given of the fituation of thefe vaft bodies of water, and their near approach to each other, with my own undigefted fuppofitions of their effect on the winds, may prove perhaps, in abler hands, the means of leading to many ufeful difcoveries.

On the $\eta^{\text {th }}$ of December, $I$ arrived (as $I$ faid before) at the utmoft extent of my travels towards the weft; where I met with a large party of the Naudoweffie Indians, among whom I refided feven months. 'Thefe conftituted a part of the eight bands of the Naudoweffies of the Plains; and are termed the Wawpeentowahs, the Tintons, the Afrahcootans, the Mawhaws, and the Schians. The other three bands, whofe names are the Schianere, the Chongoufeton, and the Waddapawjeftin, dwell higher up; to the weft of the River St. Pierre, on plains that, accord- 


\section{( 75$)$}

ing to their account, are unbounded; and probably terminate on the coaft of the Pacific Ocean. The Naudoweffie nation, when united, confifts of more than two thoufand warriors. The Affinipoils, who revolted from them, amount to about three hundred; and leagued with the Killiftinoes, live in a continual ftate of enmity with the other eleven bands.

As I proceeded up the River St: Pierre, and had nearly reached the place where thefe pcople were encamped, I ubferved two or three canoes coming down the ftream; but no fooner had the Indians that were on board them difcovered us, than they rowed toward the land, and leaping anhore with precipitation, left their canoes to float as the current drove them. In a few minutes I perceived fome others; who, as foon as they. came in fight, followed, with equal fpeed, the example of their countrymen.

I now thought it neceffary to proceed with caution; and therefore kept on the fide of the river oppofite to that on which the Indians had landed. However, I ftill continued my courfe, fatisfied that the pipe of pcace which was fixed at the head of my canoe, 


\section{( $\left.7^{6}\right)$}

and the Englifh colours that were flying at the ftern, would prove my fecurity. After rowing about half a mile farther, in turning a point, I difcovered a great number of tents, and mose than a thoufand Indians, at a little diftance from the fhore. Being now nearly oppofite to them, I ordered my men to pull directly over, as I was willing to convince the Indians by fuch a ftep, that I placed fome confidence in them.

As foon as I had reached the land, two of the chiefs prefented their hands to me, and led me, amidft the aftonifhed multitude, who had moft of them never feen a white man before, to a tent. Into this we entered, and according to the cuftom that univerfally prevails among every Indian nation, began to frnoke the pipe of Peace. We had not fat long before the crowd became fo great, both around, and upon the tent, that we were in danger of being crufhed by its fall. . On this we returned to the plain, where having gratified the curiofity of the common people, their wonder abated, and ever after they treated me with great refpeet.

From the chiefs I met with the moft friendly and hofpitable reception; which induced me, 


\section{$(77)$}

me, as the feafon was fo far advanced, to take up my refidence among them during the winter. To render my ftay as comfortable as poifible, I firt endeavoured to learn their language. This I foon did fo as to make myfelf yerfectly intelligible, having before acquired fome flight knowledge of the language of thofe Indians that live on the back of the fettlements; and in confequence met with every accommodation their manner of living would afford. Nor did I want for fuch amufements as tended to make fo long a period pafs chearfully away. I frequently hunted with them; and at other times beheld with pleafure their recreations and paftimes, which I thall defcribe hereafter.

Sometimes I fat with the chiefs, and whilf we fmoked the friendly pipe, entertained them, in return for the accounts they gave me of their wars and excurfions, with a narrative of my own adventures, and a defcription of all the battles fought between the Englinh and the French in America, in many of which I had a perfonal fhare. They always paid great attention to my details, and anked many pertinent queftions relative to the European methods of making war.

I held 


\section{( 78 )}

I held thefe converfations with them in a "great meafure to procure from them fome information relative to the chief point I had conftantly in view, that of gaining a knowledge of the fituation and produce, both of their own country, and thofe that lay to the weftward of them. Nor was I difappointed in my defigns; for I procured from them much ufeful intelligence. They likewife drew for me plans of all the countries with which they were acquainted; but as I entertained no great opinion of their geographical knowledge, I placed not much dependence on them, and therefore think it unneceffary to give them to the public. Such as I afterwards found confirmed, by other accounts, or by my own obfervations, make a part of the map prefixed to this work. They draw with a piece of burnt coal, taken from the hearth, upon the infide bark of the birch tree; which is as fmooth as paper, and anfwers the fame purpores, notwithftanding it is of a yellow caft. Their fketches are made in a rude manner, but they feem to give as juft an idea of a country, although the plan is not fo exact, as more experienced draughtfmen could lo. 


\section{( 79 )}

I left the habitations of thefe hofpitable Indians the latter end of April I 767 ; but did not part from them for feveral days, as I was accompanied on my journey by near three hundred of them, among whom were many chiefs, to the mouth of the Kiver St. Pierre. At this feafon, thefe bands annually go to the great cave, before mentioned, to hold a grand council with all the other bands; wherein they fettle their operations for the enfuing year. At the fame time they carry with them their dead for interment bound up in buffaloes $\mathrm{fkins}$. Befides thofe that accompanied me, others were gone before, and the reft were to follow.

Never did I travel with fo cheerful and happy a company. But their mirth met with a fudden and a temporary allay from a violent ftorm that overtook us one day on our paffage. We had juft landed, and were preparing to fet up our tents for the night, when a heavy cloud overfpread the heavens, and the moft dreadful thunder, lightning, and rain iffued from it, that ever I beheld.

The Indians were greatly terrified, and ran to fuch onelter as they could find; for only a few tents were as yet erected. Apprehenfive 


\section{( 80$)$}

henfive of the danger that might enfue from ftanding near any thing which could ferve for a conductor, as the cloud appeared to contain fuch an uncommon quantity of the electrical fluid, I took my ftand as far as poffible from any covering; chufing rather to be expofed to the peltings of the form than to receive a fatal ftroke. At this the Indians were greatly furprized, and drew conclufions from it not unfavourable to the opinion they already entertained of my refolution. Yet $\mathrm{I}$ acknowledge that I was never more arfected in my life; for nothing fcarcely could exceed the terrific fcene. The peals of thunder were fo loud that they thook the earth; and the lightning flarhed along the ground in ftreans of fulphur; fo that the Indian chiefs themfelves, although their courage in war is ufually invincible, could not help trembling at the horrid combution. As foon as the ftorm was over, they flocked around me, and informed me that it was a proof of the anger of the evil fpirits, whom they were apprehenfive that they had highly offended.

When we arrived at the Great Cave, and the Indians had depofited the remains of their deceafed friends in the burial-place that ftands 


\section{( $8 \mathrm{r})$}

ftands adjacent to it, they held their great council, into which I was admitted, and at the fame time had the honour to be inftalled or adopted a chief of their bands. On this occafion I made the following fpeech, which $I$ infert to give my readers a fpecimen of the language and manner in which it is neceffary to addrefs the Indians, fo as to engage their attention, and to render the fpeaker's expreffions confonant to their ideas. It was delivered on the firft day of May 1767 .

"My brothers, chiefs of the numerous and " powerful Naudoweffies! I rejoice that " through my long abode with you, I can " now fpeak to you (though after an imper" fect manner) in your own tongue, like one " of your own children. I rejoice alfo that "I have had an opportunity fo frequently to " inform you of the glory and power of the "Great King that reigns over the Englin " and other nations; who is defcended from " a very ancient race of fovereigns, as old as "the earth and waters; whofe feet ftand on " two great iflands, larger than any you have? " ever feen, amidft the greateft waters in the "world; whofe head reaches to the fun, and " whofe arns encircle the whole earth, The 


\section{$(82)$}

" number of whole warriors are equal to the "trees in the vallies, the ftalks of rice in " yonder marihes, or the blades of grais on "your great plains. Who has hundreds of " canoes of his own, of fuch amazing big"nefs, that all the water's in your country "would not fuffice for one of them to fwim " in ; each of which have guns, not fmall "like mine which you fee before you, but " of fach magnitude, that a hundred of your " ftouteft young men would with difficulty "be able to carry one. And thefe are equal"ly furprizing in their operation againt the" "great king's enemies when engaged in bat" tle; the terror they carry with them your "language wants words to exprefs. You" " may remember the other day when we were "encamping at Wadawpawmenefoter, the "black clouds, the wind, the fire, the ftu"pendous noire, the horrible cracks, and the " trembling of the earth which then alarmed "you, and gave you reafon to think your "gads were angry with you; not unli. "thefe are the warlike implements of the "Englifh when they are fighting the battles " of their great king. 


\section{$(83)$}

"Several of the chiefs of your bands have " often told me, in times paft, when I dwelt "with you in your tents, that they much "winhed to be counted among the children " and allies of the great king my mafter. You " may remember how often you have defired " me, when I return again to my own coun" try, to acquaint the great king of-your good "difpofition towards him and his fubjects, "and that you wifhed for traders from the "Englifh to come among you. Being now "about to take my leave of you, and to re"turn to my own country, a long way to" wards the rifing fun, I again ank you to tell " me whether you continue of the fame mind " as when I fpoke to you in council laft win"ter; and as there are now feveral of your " chiefs here; who came from the great plains "towards the fetting of the fun, whom I " have never fpoke with in council before, I " afk you to let me know if you are all willing " to acknowledge yourfelves the children of "my. great mafter the king of the Englinh " and other nations, as I fhall take the firt "opportunity to acquaint him of your de"fires and good intentions, I charge you not " to give heed to bad reports; for there are 


\section{( 84 )}

" wicked birds flying about among the neigh"bouring nations, who may whifper evil "things in your cars againft the Englifh, con" trary to what I have told you; you muft " not believe them, for I have told you the " truth.

"And as to the chiefs who are about to go "to Michillimackinac, I thall take care to " make for them and their fuite, a ftraight " road, fmooth waters, and a clear 1ky; that " they may go there, and fmoke the pipe of " peace, and reft fecure on a beaver blanket " under the thade of the great tree of peace. "Farewell."

To this fpeech I received the following anfwer, from the mouth of the principal chief.

"Good brother! I am now about to " fpeak to you with the mouths of thefe my " brothers, chiefs of the eight bands of the " powerful nation of the Naudoweffres. We "believe and are-well fatisfied in the truth of "every thing you have told us about your "great nation, and the Great King our "greateft father; for whom we fpread this " beaver blanket, that his fatherly protection " may ever reft eafy and fafe among us 


\section{$(85)$}

" his children: your colours and your arms " agree with the accounts you have given us " about your great nation. Wc defire that "when you return, you will acquaint the "Great King he'v much the Naudoweffies " wifh to be counted among his good children. "You may believe us when we tell you that " we will not open our ears to any who may "dare to fpeak evil of our Great Father the " king of the Englinh and other nations. "We thank you for what you have done " for us in making peace between the Nau"doweffies and the Chipeways, and hope "when you return to us again, that you will " complete this good work; and quite difpel" ling the clouds that intervene, open the "blue fky of peace, and caufe the bloody. " hatchet to be deep buried under the roots. " of the great tree of peace.

"We wifh you to remember to reprefent "to our Great Father, how much we defire " that traders may be fent to abide among us, "with fuch things as we need, that the "hearts of our young men, our wives, and " children may be made glad. And may "peace fubfilt between us, fo long as the run, 


\section{(86)}

" the moon, the earth, and the waters fhall "endure. Farewell."

I thought it neceffary to caution the Indians againft giving heed to any bad reports that may reach them from the neighbouring nations to the difadvantage of the Englinh, as I had heard, at different places through which I paffed, that emiffaries were ftill employed by the French to detach thofe who were friendly to the Engliph from their iritereft, And I faw, myfelf, feveral belts of Wampum that had been delivered for this purpofe to fome of the tribes 1 was among. On the delivery of each of thefe a Talk was held, wherein the Indians were told that the Englifh, who were but a petty people, had ftolen that country from their Great Father the king of France whilft he was aneep; but that he would foor awake, and take them again under his protection. Thefe I found were fent from Canada by perfons who appeared to be well affected towards the government under which they lived.

Whilf I tarried at the mouth of the River St. Pierre with thefe friendly Indians, I endeavoured to gain intelligence whether any goods had been fent towards the Falls of St. 


\section{( 87.$)$}

Anthony for my ufe, agreeable to the promife I had received from the governor when I left Michillimackinac. But finding from fome Indians, who paffed by in their return from thofe parts, that this agreement had not been fulfilled, I was obliged to give up all thoughts of proceeding farther to the north-weft by this route, according to my original plan. I therefore returned to La. Prairie le Chien, where I procured as many goods from the traders I left there the preceding year as they could fpare.

As thefe however were not fufficient to enable me to renew my firft defign, I dctermined to endeavour to make my way acrors the country of the Chipeways to Lake Superior; in hopes of meeting at the Grand Portage on the north fide of it, the traders that annually go from Michillimackinac to the north-weft; of whom I doubted not but that I hould be able to procure goods enough to anfwer my purpofe, and alfo to penetrate through thofe more northern parts to the Streights of $\mathrm{An}$ nian.

And the more readily returned to La Prairie le Chien, as I could by that means the better fulfil the engagement I had made 


\section{( 88$)$}

to the party of Naudoweffies mentioned at the conclufion of my fpeech. During my abode with this people, wifhing to fecure them entirely in the intereft of the Englifh, I had advifed fome of the chiefs to go to Michillimackinac, where they would have an opportunity of trading, and of hearing the accounts that I had entertained them with of my countrymen confirmed.: At the fame time I had furnifhed them with a recommendation to the governor, and given them every direction neceffary for their voyage.

In confequence of this one of the principal chiefs, and twenty-five of an inferior rank, agreed to go the enfuing fummer. 'This they took an opportunity of doing when they came with the reft of their band to attend the grand council at the mouth of the River St. Pierre. Being obliged, on account of the difappointment I had juft been informed of, to return fo far down the Miffifippi, I could from thence the more eafily fet them on their journey.

As the intermediate parts of this river are much frequented by the Chipéways, with whom the Naudoweffies are continually at 


\section{$(89)$}

war, they thought it more prudent, being but a fmall party, to take the advantage of the night, than to travel with me by day; accordingly no fooner was the grand council broke up, than I took a friendly leave of thefe people, from whom I had received innumerable civilities, and purfued once more my voyage.

I reached the eaftern fide of Lake Pepin the fame night, where I went afhore and encamped as ufual. The next morning, when I had proceeded fome miles farther, I perceived at a diftance before me a fmoke, which denoted that fome Indians were near; and in a Thort time difcovered ten or twelve tents not far from the bank of the river. As I was apprehenfive that this was a party of the Rovers I had before met with, I knew not what courfe to purfue. My attendants perfuaded me to endeavour to pafs by them o: the oppofite fide of the river; but as I had hitherto found that the beft way to enfure a friendly reception from the Indians is to meet them boldly, and without thewing any tokens of fear, I would by no means confent to their propofal. Inftead of this I croffed directly over, andlanded in the midet of them, for 


\section{( 90$)$}

by this time the greateft part of them were ftanding on the thore.

The firf 1 accofted were Chipeways inhabiting near the Ottowaw lakes; who received me with great cordiality, and thook me by the hand in token of friendihip. At fome little diftance behind thefe ftood a chief remarkably tall and well made, but of fo ftern an afpect that the moft undaunted perfon could not behold him without feeling fome degree of terror. He feemed to have paffed the meridian of life, and by the mode in which he was painted and tatowed, I difcovered that he was of high rank. However, I approached him in a courteous manner, and expected to have met with the fame reception I had done from the others: but to my great furprize he with-held his hand, and looking fiercely at me, faid in the Chipéway tongue; "Cawin nifhifhin faganofh", that is, "The Englifh are no good." As he had his tomahawk in his hand, I expected that this laconick fentence would have been followed bys a blow; to prevent which I drew a piftol from my belt, and, holding it in a carelefs pofition, paffed clofe by him, to let him fee I was not afraid of him.

I learned 


\section{( 9I)}

I learned foon after from the other Indians that his was a chief, called by the French the Grand Sautor, or the Great Chipéway Chief, for they denominate the Chipeways Sautors. They likewife told me that he had been always a fteady friend to that people, and when they delivered up Michillimackinac to the Englin on their evacuation of Canada, the Grand Sautor had fworn that he would ever remain the avowed enemy of its new poffeffors, as the territories on which the fort is built belonged to him.

Finding him thus difpofed, I took care to be conftantly upon my guard whilf I ftaid; but that he might not fuppofe I was driven away by his frowns, I took up my abode there for the night: I pitched my tent at fome diftance from the Indians, and had no fooner laid myfelf down to reft, than I was awaked by my French fervant. Having been alarmed by the found of Indian mufic, he had run to the outfide of the tent, where he beheld a party of the young favages dancing to wards us in an extraordinafy manner, each carrying in his hand a torch fixed on the top of a long pole. But I thall defer any further account of this uncommon entertain.

ment, 


\section{(92)}

ment, which at once furprized and alarmed me, till I treat of the Indian dances.

The next morning I continued my voyage, and before night reached La Prairie le Chien; at which place the party of Naudoweffies foon overtook me. Not long after the Grand Sautor alfo arrived, and before the Naudoweffies left that place to continue their journey to Michillimackinac, he found means; in conjunction with fome French traders trom Louifiana, to draw from me about ten of the Naudoweffie chiefs, whom he prevailed upon to go towards thofe parts.

The remainder proceeded according to iny direcitions, to the Englifh fort ; from whence I afterwards heard that they returned to their own country without any unfortunate accident befalling them, and greatly pleafed with the reception they had met with. Whilft not more than half of thofe who went to the fouthward, through the difference of that fouthern climate from their own, lived to reach their abode. And fince I came to England I have been informed, that the Grand Sautor hing rendered himfelf more and more difguftful to the Englin by his inveterate enmity towards them, was at length ftabbed 


\section{( 93 )}

fabbed in his tent, as he encamped near $\mathrm{Mi}$ chillimackinac, by a trader to whom I had related the foregoing ftory.

I hould have remarked, that whatever Indians happen to meet at La Prairie le Chien, the great mart to which all who inhabit the adjacent countries refort, inough the nations to which they belong are at war with each other, yet they are obliged to reftrain their enmity, and to forbear all hoftile acts during their ftay there. This regulation has been long eftablifhed among them for their mutual convenience, as without it no trade could be carried on. The fame rule is obferved alfo at the Red Mountain (afterwards defcribed) from whence they get the ftone of which they make their pipes: thefe being indifpenfable to the accommodation of every neighbouring tribe, a fimilar reftriction becomes needful, and is of public utility.

The River St. Pierre, which runs through the territories of the Naudoweffies, flows through a moft delightful country, abounding with all the neceffaries of life, that grow fpontaneoufly; and with a little cultivation it might be made to produce even the luxuries of life. Wild rice grows here in great abundạnce; 


\section{( 94$)$}

abundance; and every part is filled with trees bending under their loads of fruits, fuch as plums, grapes, and apples; the meadows are covered with hops, and many forts of vegetables; whilft the ground is ftored with ufeful roots, with angelica, fpikenard, and ground-nuts as large as hens eggs. At a little diftance from the fides of the river are eminences, from which you have views that cannot be exceeded even by the moit beautiful of thofe I have already defcribed; amidft thefe are delightful groves, and fuch amazing quantities of maples, that they would produce fugar fufficient for any number of inhabitants.

A little way from the mouth of this river," on the north fide of it, ftands a hill, one part of which, that towards the Miffiffippi, is compofed entirely of white ftone, of the fame foft nature as that I have before defcribed; for fuch,--indeed, is all the ftone in this country. But what appears remarkable is, that the colour of it is as white as the driven fnow. The outward part of it was crumbled by the wind and weather into heaps of fand, of which a beautiful compofition might be made; or, I am of opinion 


\section{( 95$)$}

that when properly treated the fone itfelf would grow harder by time, and have a very noble effect in architecture.

Near that branch which is termed the Marble River, is a mountain, from whence the Indians get a fort of red ftone, out of which they hew the bowls of their pipes. In fome of thefe parts is found a black hard clay, or rather ftone, of which the Naudoweffies mal:e their family utenfils. 'This country likewife abounds with a milk white clay, of which China ware might be made equal in goodnefs to the Afiatic; and alfo with a blue clay that ferves the Indians for paint; with this laft they contrive, by mixing it with the red ftone powder, to paint themfelves of different colours. Thofe that can get the blue clay here mentioned, paint themfelves very. much with it; particularly when they are about to begin their fports and paftimes. It is alfo efteemed by them a mark of peace, as it has a refemblance of the blue $\mathrm{fky}$; which with them is a fymbol of it, and made ufe of in their fpeeches as a figurative expreffion to denote peace. When they wifh to hew that their inclinations are pacific 'towards other

tribes, 


\section{( 96$)$}

tribes, they greatly ornament both themfelves and their belts with it.

Having concluded my bufinefs at La Prairie le Chien, I proceeded once more up the Miffiflippi, as far as the place where the Chipeway River enters it a little below Lake Pepin. Here, having engaged an Indian pilot, I directed him to fteer towards the Ottowaw Lakes which lie near the head of this river. This he did, and I arrrived at them the beginning of July.

The Chipéway River, at its junction with the Miffiffippi, is about eighty yards wide, but it is much wider as you advance into it. Near thirty miles up it feparates into two branches, and I took my courfe through that which lies to the eaftward.

The country adjoining to the river, for about fixty miles, is very level, and on its banks lie fine meadows, where larger droves of buffaloes and elks were feeding, than I had obferved in any other part of my travels. The track between the two branches. of this river is termed the Road of War between the Chipéway and Naudoweffie Indians. 


\section{(97)}

The country to the Falls marked in the plan at the extent of the traders travels, is almoft without any timber, and above that very uneven and rugged, and clofely wooded with pines, beach, maple, and birch. Here a moft remarkable and aftonifhing fight prefented itfelf to my view. In a wood, on the eaft of the river, which was about the quarters of a mile in length, and in depth farther than my eye could reach, I obferved that every tree, many of which were more than fix feet in circumference, was lying flat on the ground torn up by the roots. This appeared to have been done by fome extraordinary hurricane that came from the weft fome years ago, but how many I could not learn, as I found no inhabitants near it, of whom I could gain information. The country on the weft fide of the river, from being lefs woody, had elcaped in a great meafure this havock, as only a few trees were blown down.

Near the heads of this river is a town of the Chipéways, from whence it takes its name. It is fituated on each fide of the river (which at this place is of no confiderable breadth) and lies adjacent to the banks of a 


\section{( 98$)$}

finall lake. This town contains about forty houfes, and can fend out upwards of one hundred warriors, many of whom were fine ftout young men. The houfes of it are built after the Indian manner, and have neat plantations behind them; but the inhabitants, in general, feemcd to be the naftieft people I had ever been among. I obferved that the women and children indulged themfelves in a cuitom, which though common, in fome degree, throughout every Indian nation, appears to be, according to our ideas, of the moft naufeous and indelicate nature; that of fearching each other's head, and eating the prey caught therein.

In July I left this town, and having croffed a number of finall lakes and carrying places that intervened, came to a head branch of the River St. Croix. This branch I defcended to a fork, and then afcended another to its fource. On both thefe rivers I difcovered feveral mines of virgin copper, which was as pure as that found in any other country.

Here I came to a fmall brook, which my guide thought might be joined at fome diftance by ftreams that would at length render 


\section{( 99 )}

it navigable. The water at firft was fo fcanty, that my canoe would by no means fwim in it ; but having ftopped up feveral old beaver dams which had been broke down by the hunters, I was enabled to proceed for fome miles, till by the conjunction of a few brooks, thefe aids became no longer neceffary. In a thort time the rater increafed to a moft rapid river, which we defcended till it entered into Lake Superior. This river I named after a gentleman that defired to accompany me from the town of the Ottagaumies to the Carrying Place on Lake Superior, Goddard's river.

To the weft of this is another finall river, which alfo empties itfelf into the Lake. This I termed Strawberry River, from the great number of Atrawberries of a good fize and fine flavour that grew on its banks.

The country from the Ottowaw Lakes to Lake Superior is in general very uneven and thickly covered with woods. The foil in fome places tolerably good; in others but indifferent. In the heads of the St. Croix, and the Chiperway Rivers, are exceeding fine furgeon. All the wildernefs between the Miffiffippi and Lake Superior is called by the $\mathrm{H}_{2}$

Indians 


\section{$(100)$}

Indians the Mofchettoe country, and I thought it moft juftly named; for, it being then their feafon, I never faw or felt fo many of thofe infects in my life.

The latter end of July I arrived, after having coafted through Weft Bay, at the Grand Portage, which lies on the north-wert borders of Lake Superior. Here thofe who go on the north-weft trade, to the Lakes De Pluye, Dubois, \&c. carry over their canoes and baggage about nine miles, till they come to a number of fmall lakes, the waters of fome of which defcend into Lake Superior, and others into the River Bourbon. Lake Superior from Weft Bay to this place is bounded by rocks, except towards the fouthweft part of the Bay where I firft entered it, there it was tolcrably level.

At the Grand Portage is a fmall bay, before the entrance of which lies an inland that intercepts the dreary and uninterrupted view over' the Lake which otherwife would have prefented itfelf, and makes the bay ferene and pleafant. Here I met a large party: of Killifinoe and Affinipoil Indians, with their refpective kings and their families. They were come to this place in order to meet the traders 


\section{( 101$)$}

traders from Michillimackinac, who make this their road to the north-weft. From them I received the following account of the Jakes that lie to the north-weft of Lake Superior.

Lake Bourbon, the moft northern of thofe yet difcovered, received its name from fome French traders who accompanied a party of Indians to Hudfon's Bay fome years ago: and was thus denomizated by them in honour of the royal family of France. It is compofed of the waters of the Bourbon River, which, as I have before obferved, rifes a great way to the fouthward, not far from the northern heads of the Miffiffippi.

This Lake is about eighty miles in length, north and fouth, and is nearly circular. It has no very large iflands on it. The land on the eaftern fide is very good; and to the fouth-weft there are fome mountains: In many other parts there are barren plains, bogs, and moraffes. Its latitude is between fifty-two and fifty-four degrees north, and it lies nearly fouth-weft from Hudfon's Bay. As through its northern fituation the weather there is extremely cold, only a few animals are to be found in the country that borders 


\section{(102)}

on it. They gave me but an indifferent account either of the beafts, birds, or firhes. There are indeed fome buffaloes of a fmall fize, which are fat and good about the latter end of the fummer, with a few moofe and carriboo deer; however this deficiency is made up by the furs of every. fort that are to be met with in great plenty around the Lake. The timber growing here is chiefly fir, cedar, fpruce, and fome maple.

Lake Winnepeek, or as the French write it Lac Ouinipique, which lies neareft to the foregoing, is compofed of the fame waters. It is in length about two hundred miles north and fouth; its breadth has never been properly afcertained, but is fuppofed to be about one hundred miles in its wideft part. This Lake is very full of illands; thefe are, however, of no great magnitude. Many confiderable rivers empty themfelves into it, which, as yet, are not diftinguifhed by any names. The waters are ftored with fifh, fuch as trout and fturgeon, and alfo with others of a fmaller kind peculiar to thefe lakes.

The land on the fouth-weft part of it is very good, efpecially about the entrance of a large 


\section{( 103$)$}

a large branch of the River Bourbon which flows from the fouth-weft. On this River there is a factory that was built by the French called Fort La Reine, to which the traders from Michillimackinac refort to trade with the Affinipoils and Killiftinoes. To this place the Mahahs, who inhabit a country two hundred and fifty miles fouth-weft, come alfo to trade with them; and bring great quantities of Indian corn to exchange for knives, tomahawks, and other articles. Thefe people are fuppofed to dwell on fome of the branches of the river of the weft.

Lake Winnepeek has on the north-eaft fome mountains, and on the eaft many barren plains. The maple or fugar tree grows here in great plenty, and there is likewife gathered an amazing quantity of rice, which proves that grain will flourifh in thefe northern climates as well as in warmer. Buffaloes, carraboo, and moofe deer, are numcrous in thefe parts. The buffaloes of this country differ from thofe that are found more to the fouth only in fizi; the former being much fmaller: juft as the black cattle of the northern parts of Great Britain differ from Englifh oxen: 


\section{( 104$)$}

On the waters that fall into this Lake, the neighbouring nations take great numbers of excillent furs. Some of thefe they carry to the factories and fettlements belonging to Hudfon's Bay Company, fituated about the entrance of the Bourbon River: but this they do with reluctance on feveral accounts; for fome of the Affinipoils and Killiftinoes, who ufually traded with the Company's fervants, told me, that if they could be fure of a conftant fupply of goods from Michillimackinac, they would not trade any where elfe. They thewed me fome cloth and other articles that they had purchafed at Hudfon's Bay, with which they were much diffatisfied, thinking they had been greatly impofed upon in the barter.

Allowing that their accolints were true, I could not help joining in their opinion. But this diffatisfaction might probably proceed, in a great meafure, from the intrigues of the Canadian traders: for whilf the French were in poffefion of Michillimackinac, having acquired a thorough knowledge of the trade of the north-weft countries, they were employed on that account; after the reduction of $\mathrm{Ca}$ nada, by the Englin traders there, in the eftablifhment

eftabl

were

of th

India

fon's

good

ers,

Coint

tages

ing $e$

this't

doubl

poils

proce

it ; a

to th

infor

durin

and $f$

could

beave

wond

to ha

It is $t$

in the

but $t$

fity 0 


\section{( 105$)$}

eftablimment of this trade with which they were themfelves quite unacquainted. One of the methods they took to withdraw thefe, Indians from their attachment to the Hudfon's Bay Company, and to engage their good opinion in behalf of their new employers, was by depreciating on all occafions the Company's goods, and magnifying the advantages that would arife to them from trafficking entirely with the Canadian traders. In this they too well fucceeded, and from this, doubtlefs, did the diffatisfaction the Affinipoils and Killiftinoes expreffed to me, partly proceed. But another reafon augmented it ; and this was the length of their journey to the Hudfon's Bay factories, which, they informed me, took them up three months during the fummer heats to go and return, and from the fmallnefs of their canoes they could not carry more than a third of the beavers they killed. So that it is not to be wondered at, that thefe Indians fhould wirh to have traders come to refide among them. It is true that the parts they inhabit are within the limits of the Hudfon's Bay territories, but the Company muft be under the necerfity of winking at an encroachment of this kind, 


\section{( 106$)$}

kind, as the Indians would without doubt protect the traders when among them. Befides, the paifports granted to the traders that go from Michillimackinac give them liberty to trade to the north-weft about Lake Superior; by which is meant Fort La Reine, Lake Winnepeek, or any other parts of the waters of the Bourbon River, where the Couriers de Bois, or Traders may make it moft convenient to refide.

Lac du Bois, as it is commonly termed by the French in their maps, or in Englim the Lake of the Wood, is fo called from the multiplicity of wood growing on its baniss; fuch as oaiks, pines, firs, fpruce, \&c. This Lake lies fill higher up a branch of the River Bourbon, and nearly cant from the fouth end of the Lake Winnepeek. It is of great depth in fome places. Its length from eaft to weft about feventy miles, and its greateft breadth about forty miles. It has but few inlands; and thefe of no great magnitude. The firhes, fowls; and quadrupeds thai are found near it, vary but little from thofe of the other two lakes. A few of the Killiftinoe Indians fometimes encamp on the borders of it to fith and hunt."

'This 


\section{( 107$)$}

This Lake lies in the communication between Lake Superior, and the Lakes Winnepeek and Bourbon. Its waters are not efteemed quite fo pure as thofe of the other lakes, it having, in many places, a muddy bottom.

Lac La Pluye, fo called by the French, in Englim the Rainy Lake, is fuppofed to have acquired this name from the firft travellers, that paffed over it, meeting with an uncommon deal of rain; or, as fome have affirmed, from a mift like rain occafioned by a perpendicular water-fall that empties itfelf into a river which lies to the fouth-wet.

This Lake appears to be divided by an Ifthmus, near the middle, into two parts: the weft part is called the Great Rainy Lake, the eaft, the Little Rainy Lake, as being the leaft divifion. It lies a few miles farther to the eaftward, on the fame branch of the Bourbon, than the laft-mentioned lake. It is in general very fhallow in its depth. The broadeft part of it is not more than twenty miles, its length, including both, about three hundred miles. In the weft part the water is very clear and good; and fome excellent filh are taken in it. A great many fowl re- 


\section{( 108$)$}

fort here at the fall of the year. Moofe deer are to be found in great plenty, and likewife the carraboo; whole fkin for breeches or gloves exceeds by far any other to be met with in North-America. The land on the borders of this Lake is efteemed in fome places very good, but rather too thickly covered with wood. Here refide a confiderable band of the Chipeways.

Eaftward from this Lake lie feveral fmall ones, which extend in a ftring to the great carrying place, and from thence into Lake Superior. Between thefe little lak are feveral carrying places, which render the trade to the north-weft difficult to accomplinh, and exceedingly tedious, as it takes two years to make one voyage from Michillimackinac to thefe parts.

Red Lake is a comparatively fmall lake at the head of a branch of th: Bourbon River, which is called by fome Red River. Its forta is nearly round, and about fixtý miles in ci. cumference. On one fide of it is a tolerable large ifland, clofe by which a fmall river enters. It bears almoft fnuth-eaft both from Lake Winnepeek and i.om Lake du Boiș. The parts adjacent are very little known, 


\section{( 109$)$}

or frequented, even by the favages themfelves.

Not far from this Lake, a little to the fouth-weft, is another called White Bear Lake, which is nearly about the fize of the laft mentioned. The waters that compore this Lake are the moft northern of any ti.at fupply the Miffiffippi, and may be called with propriety is moft remote fource. It is fed by two or three fmall rivers, or rather large brooks.

A few miles from it, to the fouth-eaft, are a great number of fmall lakes, none of which are more than ten miles in circumference, that are called the Thoufand Lakes. In the adjacent country is reckoned the fineft hunting for furs of any on this continent; the Indians who hunt here feldom returning without having their canoes loaded as deep as they can fwim.

Having juft before obferved that this Lake is the utmoft northern fource of the Miffifippi, I thall here further remark, that before this river enters the Gulph of Mexico, it has not runlefs, through all its meanderings, than three thoufand miles; or, in a ftrait line from north to fouth, about twenty degrees, which 


\section{(110)}

which is nearly fourteen hundred Englißh miles.

Thefe Indians informed me, that to the north-weft of Lake Winnepeek lies another whofe circumference vaftly exceeded any they had given me an account of. They defcribe it as much larger than Lake Superior. But as it appears to be fo far to the north-weft, I Should imagine that it was not a lake, but rather the Archipelago or broken waters that form the communication between Hudfon's Bay and the northern parts of the Pacific Ocean.

There are an infinite number of fmall lakes, on the more weftern parts of the weftern head-branches or the Miffiffippi, as well as between thefe and Lake Winnepeek, but none of them are large enough to fuppofe either of them to be the lake or waters meant by the Indians.

They likewife informed me, that fome of the northern branches of the Mefforie and the fouthern branches of the St. Pierre have a communication with each other, except for a mile; over which they carry their canoes. And by what I could learn from them, this is the road they take when their war parties make 


\section{( III)}

make their excurfions upon the Pawnees and Pawnawnees, nations inhabiting fome branches of the Mefforie River. In the country belonging to there people it is faid, that Mandrakes are frequently found, a fpecies of root refembling human beings of both fexes; and that thefe are more perfect than' fuch as are difcovered about the Nile in NetherEthiopia.

A little to the north-weft of the heads of the Mefforie and the St. Pierre, the Indians further told me, that there was a nation rather fmaller and whiter than the neighbouring tribes, who cultivate the ground, and (as far as I could gather from their expreffions) in fome meafure, the arts. To this account they added that fome of the nations, who inhabit thofe parts that lie to the weft of the Shining Mountains, have gold fo plenty among them that they make their moft cornmon utenfils of it. Thefe mountains (which I thall defcribe more particularly hereafter) divide the waters that fall into the South Sea from thofe that run into the Atlantic.

The people dwelling near them are/ fuppofed to be forne of the different tribes that were tributary to the Mexican kings, and who 


\section{(II2)}

who fled from their native country to feek an afylum in thefe parts, about the time of the conqueft of Mexico by the Spaniards, more than two centuries ago.

As fome confirmation of this fuppofition it is rcmarked, that they have chofen the moft interior parts for their retreat, being ftill prepoffeffed with a notion that the fea coafts have been infefted ever fince with monfters vomiting fire, and hurling about thunder and lightning; from whofe bowels iffued men, who, with unfeen infruments, or by the power of magic, killed the hai mlefs Indians at an aftonifhing diftance. From fuch as thefe, their fore-fathers (according to a tradition among them that ftill remains unimpaired) fled to the retired abodes they now inhabit. For as they found that the floating monfters which had thus terrified them could not approach the land, and that thore who had defeended from their fides did not care to make excurfions to any confiderable diftance from them, they formed a refolution to betake themfelves to fome country, that lay far from the fea-coafts, where only they could be fecure from fuch diabolical enemies. They accordingly fet out with their families, and 


\section{( Ir:3)}

and after a long peregrination, fettled themfelves near thefe mountains, where they concluded they had found a place of perfect fecurity.

The Winnebagoes, dwelling on the Fox River (whom I have already treated of) are likewife fuppofed to be fome ftrolling band from the Mexican countries. But they are able to give only an imperfect account of their original refidence. They fay they formerly came a great way from the weftward, and were driven by wars to take refuge among the Naudoweflies; but as they are entirely ignorant of the arts, or of the value of gold, it is rather to be fuppofed, that they were driven from their ancient fettlements by the above-mentioned emigrants, as they paffed on towards their prefent habitation.

Thefe fuppofitions, however, may want confirmation; for the fmaller tribes of Indians are fubject to fuch various alterations in their places of abode, from the wars they are continually engaged in, that it is almort impoffible to afcertain, after half a century, the original fituation of any of them.

That range of mountains, of which the Shining Mountains are a part, begin at Mexico, 


\section{( 114$)$}

ico, and continuing northward on the back, or to the eaft of California, feparate the waters of thofe numerous rivers that fall cither into the Gulph of Mexico, or the Gulph of California. From thence continuing their courfe ftill northward, between the fources of the Miffiflippi and the rivers that run into the South Sea, they appear to end in about forty-feven or forty-eight degrees of north latitude; where a number of rivers arife, and empty themfelves either into the South Sea, into Hudfon's Bay, or into the waters that communicate between thefe two feas.

Among thefe mountains, thofe that lie to the weft of the River St. Pierre, are called the Shining Mountains, from an infinite number of chryftal ftones, of an amazing. fize, with which they are covered, and which, when the fun thines full upon them, fparkle fo as to be feen at a very great diftance.

This extraordinary range of mountains is calculated to be more than three thoufand miles in length, without any very confiderable intervals, which I believe furpaffes any thing of the kind in the other quarters of the globe. Probably in future ages they may 


\section{(115)}

be found to contain more riches in their bowels, than thofe of Indoftan and Malabar, or that are produced on the Golden Coaft of Guinea; nor will I except even the Peruvian Mines. To the wert of thefe mountains, when explored by future Columbures or Raleighs, may be found other lakes, rivers, and countries, full fraught with all the necefiaries or luxuries of life; and where future generations may find an afylum, whether driven from their country by the ravages of lawlefs tyrants, or by religious perfecutions, or reluctantly leaving it to remedy the inconveniencies arifing from a fuperabundant increafe of inhabitants; whether, I fay, impelled by thefe, or allured by hopes of commercial advantages, there is little doubt but their expectations will be fully gratified in thefe rich and unexhaunted climes.

But to return to the Affinipoils and Killiftinoes, whom I left at t' 1 e Grand Portage, and from whom I received the foregoing account of the lakes that lie to the north-weft of this place.

The traders we expected being later this feafon than ufual, and our numbers very confiderable, for there were more than three hundred 


\section{(116)}

hundred of us, the ftock of provifions we had brought with us was ncarly exhaufted, and we waited with impatience for their arrival.

One day, whilft we were all expreffing our withes for this defirable event, and looking from an eminence in hopes of feeing them come over the Lake, the chief priet belonging to the band of the Killiftinoes told us, that he would endeavour to obtain a conference with the Great Spirit, and know from him when the traders would arrive. I paid little attention to this declaration, fuppofing that it would be productive of fome juggling trick, juft fufficiently covered to deceive the ignorant Indians. But the king of that tribe telling me that it was chiefly undertaken by the prieft to alleviate my anxiety, and at the fame time to convince me how much intereft he had with the Great Spirit, I thought if neceffary to reftrain my animadverfions on his defign.

The following evening was fixed upon for this fpiritual conference. When every thing had been properly prepared, the king came to ine and led me to a capacious tent, the covering of which was drawn up, fo as to render what was tranfacting within vifible to thofe 


\section{$\left(\mathrm{II}_{7}\right)$}

who ftood without. We found the tent furrounded by a great number of the Indians, but we readily gained admiffion, and feated ourfelves on tkins laid on the ground for that: purpofe.

In the centre I obferved that there was a place of an oblong thape, which was compofed of ftakes ftuck in the ground, with intervals between, fo as to form a kind of cheft or coffin, large enough to contain the body of a man. Thefe were of $a$ middle fize, and "placed at fuch a diflance from each other, that whatever lay within them was readily. to be difcerned. The tent was perfeetly illuminated by a great number of torches made of fplinters cut from the pine or birch tree, which the Indians held in their hands.

In a few minutes the prieft entered; when an amazing large elk's fkin being fpread on the ground, juft at my fect, he laid himfelf down upon it, after having ftripped himfelf of every garment except that which he wore clofe about his middle. Being now proftrate on his back, he firft laid hold of one fide of the flin, and folded it over him, and then the other; leaving only his head uncovered. This was no fooner done, than two of the 


\section{(II8)}

young men who ftood by took about forty yards of ftrong cord, made alfo of an elk's hide, and rolled it tight round his body, fo that he was completely fwathed within the kin. Being thus bound up like an Egyptian Mummy, one took him by the heels, and the other by the head, and lifted him over the pales into the inclofure. I could now alfo difcern him as plain as I had hitherto done, and I took care not to turn my eyes a moment from the object before me, that I might the more readily detect the artifice, for fuch I doubted not but that it would turn out to be.

The prieft had not lain in $t^{2}$ fituation more than a few feconds, when us began to mutter. . This he continued to do for fome time, and then by degrees grew louder and louder, till at length he fpoke articulately; however what he uttered was in fuch a mixed jargon of the Chipeway, Ottawaw, and Killiftinoe languagès, that I could underftand but very little of it. Having continued in this tone for a confiderable while, he at laft exerted his voice to its. utmoftpitch, fometimes raving and fometimes praying, till he 


\section{(119)}

had worked himfolf into fuch an agitation, that he foamed at his mouth.

After having remained near three quarters of an hour in the place, and continued his vociferation with unabated vigour, he feemed to be quite exhaufted, and remained fpeechlefs. But in an inftant he fprung upon his feet, notwithftanding at the time he was put in, it appeared impoffible for him to move either his legs or arms, and Making off his covering, as quick as if the bands with which it had been bound were burned afunder, he : began to addrefs thofe who ftood around in: a firm and audible voice. "My Brothers;... faid he, "the Great Spirit has deigned to " hold a Talk with his fervant at my earneft "requeft. He has not, indeed, told me when " the perfons we expect will be here, but to" morrow; foon after the fun has reached his " higheft point in the heavens, a canoe will " arrive, and the people in that will inform " us when the traders will come." Having faid this, he ftepped out of the inclofure, and after he had put on his robes, difmiffed the affembly. I own I was greatly aftonifhed at what I had feen, but as I obferved that every eye in the company was fixed on me with a view 


\section{( 120$)$}

view to difcover my fentiments, I carefully concealed every emution.

The next day the fun thone bright, ard long before noon all the Indians were gathered together oli the eminence that overlooked the lake. The old king came to me and anked 'me, whether I had fo much confidence in what the prieft had foretold, as to join his prople on the hill, and wait for the completion of it? I told him that I was at a lofs what opinion to form of the prediction, but that I would readily attend him. On this we walked together to the place where the others were affembled. Every eye was again fixed by turns on me and on the lake; when juft as the fun had reached his zenith, agreeable to what the prieft had foretold, a canoe came round a point of land about a league diftant. The Indians no fooner beheld it, than they fent up an univerfal thout, and by their looks feemed to triumph in the intereft their prieft thus evidently had with the Great Spirit.

In lefs than an hour the canoe reached the thore, when I attended the king and chiefs to receive thofe who were on board. As foon as the men were landed, we walked all 


\section{( I2I)}

together to the king's tent, where according to their invariable cuftom we began to fmoke; and this we did, notwithftanding our impatience to know tire tidings thry brought, without anking any queftions; for the Indians are the moft deliberate people in the world. However, after fome trivial converfation, the king enquired of them whether they had feen any thing of the traders? the men replied, that they had parted from them a few days before, and that they propofed being here the fecond day from the prefent. They accordingly arrived at that timc greatly to our fatisfaction, but more particularly fo to that of the Indians, who found by this event the importance both of their prieft and of their nation, greatly augmented in the fight of a ftranger.

This ftory I acknowledge appears to carry with it marks of great credulity in the relator. But no one is lefs tinctured with that weaknefs than myfelf. The circumftances of it $\mathrm{I}$ own are of a very cxtraordinary nature; however, as I can vouch for their being free from either exaggeration or mifreprefentation, being myfelf a cool and difpaffipnate obferver of them all, I thought it neceffary 


\section{(122)}

ceffaty to give them to the public. And this I do without winhing to minead the judgment of my readers; or to make any fuperftitious impreffions on their minds, but leaving them to draw from it what conclufions they pleare,

I have already obferved that the Affinipoils, with a party of whom I met here, are a revolted band of the Naudoweffies; who on account of fome real or imagined grievances, for the Indians in general are very tenacious of their liberty, had feparated themfelves from their countrymen, and fought for freedorn at the expence of their eafe. For the country they now inhabit about the borders of Lake Winnepeek, being much farther north, is not near fo fertile or agreeable as that they have relinquilhed. They ftill retain the language and manners of their for. mer affociates.

The Killiftinoes, now the neighbours and allies of the Affinipoils, for they alfo dwell near the fame Lake and on the waters of the River Bourbon, appear to have been originally a tribe of the Chipeways, as they Ifpeak their language, though in a different dialect. Their nation confifts of about three or four , 


\section{(123)}

hundred warriors, and they feem to be a hindy brave people. I have already given an account of their country when I treated of Lake Winnepeek. As they refide within the limits of Hudfon's Bay, they generally trade at the factories which belong to that Company, but, for the reafons mentioned before, they frequently come to the place where I happened to join them, in order to meet the traders from Michillimackinac.

The anxiety I had felt on account of the traders delay, was not much alleviated by their arrival. I again found my expectations difappointed, for I was not able to procure the goods I wanted from any of them. I was therefore obliged to give over my defigns, and return to the place from whence I firt began my extenfive circuit. I accordingly took leave of the old king of the Killiftinoes, with the chicfs of both bands; and departed. This prince was upwards of fixty years of age, tall and fightly made, but he carried himfelf very erect. He was of a courteous, affable difpofition, and treated me, as did all the chiefs, with great civility. 


\section{( 124$)$}

1 obferved that this people ftill continued a cuftom, that appeared to have been univerfal before any of them became acquainted with the Manners of the Europeans, that of complimenting ftrangers with the company of their wives; and this is not only practifed by the lower ranks, but by the chiefs themfelves, who efteem it the greateft proof of courtefy they can give a ftranger.

The beginning of October, after having coafted round the north and eaft borders of Lake Superior, I arrived at Cadot's Fort, which adjoins to the Falls of St. Marie, and is fituated near the fouth-weft corner of it.

Lake Superior, formerly termed the Upper Lake from its northern fituation, is fo called on account of its bcing fuperior in magnitude to any of the lakes on that vaft continent. It might juftly be termed the Cafpian of America, and is fuppofed to be the largeft body of frefh water on the globe. Its circumference, accordiag to the French charts, is about fifteen hundred miles; but I believe, that if it was coafted round, and the utmoft extent of every bay taken, it would exceed fixtcen hundred. 


\section{( 125$)$}

After I firft entered it from Goddard's River on the wett bay, I coafted nea: twelve hundred miles of the north and eaft hores of it, and obferved that the greateft part of that extenfive track was bounded by rocks and uneven ground: The water in general appeared to lie on a bed of of rocks. When it was calm, and the fun Thone bright, I could fit in my canoe, where the depth was upwards of fix fathoms, and plainly fee huge piles of ftone at the bottom, of different Thapes, fome of which appeared as if they were hewn. The water at this time was as pure and tranfparent as air; and my canoe feemed as if it hung fufpended in that element. It was impoffible to look attentively through this limpid medium at the rocks below, without finding, before many minutes were elapfed, your head fwim, and your eyes no longer able to behold the dazzling fcene.

I difcovered alfo by accident another extraordinary property in the waters of this lake. Though it was in the month of July that I paffed over it, and the furface of the water, from the heat of the fuper-ambient air, impregnated with no fmall degree of 


\section{(126)}

warmth, yet on letting down a cup to the depth of about a fathom, the water drawn from thence was fo exceffively cold, that it had the fame effect when received into the mouth as ice.

The fituation of this lake is variounly laid down; but from the moft exact obfervations I could make, it lies between forty-fix and fifty degrees of north latitude, and between eighty-four and ninety-three degrees of weft longitude from the meridian of London.

There are many inlands in this lake, two of which are very large; and if the land of them is proper for cultivation, there appears to be fufficient to form on each a confiderable province; efpecially on Ine Royal, which cannot be lefs than an hundred miles long, and in many places forty broad. But there is no way at prefent of afcertaining the exat length or breadth of either. Even the French, who always kept a fmall fchooner on this lake whilft they were in poffeffion of Canada, by which they could have made this difcovery, have only acquired a light knowledge of the external parts of thefe inlands; at leaft they have never publinhed any account 


\section{(. $\$ 27)$}

of the internal parts of them, that could get intelligence of.

Nor was I able to difcover from any of the converfations which I held with the neighbouring Indians, that they had ever made any fettlements on them, or even landed there in their hunting excurfions. From what I could gather by their difcourfe, they fuppofe them to have been, from their firf information, the refidence of the Great Spirit; and relate many ridiculous fories of enchantment and magical tricks that had been experienced by fuch as were obliged through ftrefs of weather to take fhelter on them.

One of the Chisway chiefs told me, that fome of their people being once driven on the inland of Maurepas, which lies towards the north-ealt part of the lake, found on it large quantities of a heavy Mining yellow fand, that from their defcription muft have. been gold duft. Being ftruck with the beautiful appearance of it, in the morning, when they re-entered their canoe, they attempted to bring fome away ; but a fpirit of an amazing fize, according to their account fixty feet in height, ftrode into the water after them, and commanded them to deliver back what they 
they had taken away. Terrified at his gigantic fature, and feeing that he had nearly overtaken them, they were glad to reftore their thining treafure; on which they were fuffered to depart without further moleftation. Since this incident, no Indian that has ever heard of it, will venture near the fame haunted coaft. Befides this, they recounted to me many other ftories of thefe inlands, equally fabulous.

The country on the north and eaft parts of Lake Superior is very mountainous and barren. The weather being intenfely cold in the winter, and the fun having but little power in the fummer, vegetation there is very flow; and confequently but little fruit is to be found on its hore. It however produces fome few fpecies in great abundance. Whirtle-berries of an uncommon fize, and fine flavour, grow on the mountains near the lake in amazing quantities; as do black currants and goofberries in the fame luxuriant manner.

But the fruit which exceeds all the others, is a berry refembling a raberry in its manner of growth, but of a lighter red, and much larger; its tante is far more delicious than the fruit 


\section{(129)}

fruit I have compared it to, notwithflanding that is fo highly efteemed in Europe: it grows on a hrub of the nature of a vine, with leaves fimilar to thofe of the grape; and I am perfuaded that was it tranfplanted into a warmer and more kindly climate, it would prove a moft rare and delicious fruit.

Two very large rivers empty themfelves into this lake, on the north and north-eaft fide ; one is called the Nipegon River, or, as the French pronounce it, the Allanipegon, which leads to a hand of the Chipeways, inhabiting a lake of the fame name, and the other is termed the Michipicooton River, the fource of which is fituated towards James's Bay, from whence there is but a Mort carriage to another river, which empties itfelf into that bay, at a fort belonging to the Company. It was by this paffage that a party of French from Michillimackinac invaded the fettlements of that Society in the reign of queen Anne. Having taken and deftroyed their forts, they brought the cannon which they found in them to the fortrefs from whence they had iffued: thefe were fmall brafs pieces, and remain there to this prefent time; having, through the ufual re- 


\section{( 130 )}

volutions of fortune, returned to the poffeffions of their former mafters.

Not far from the Nipegon is a fmall river, that, juft before it enters the lake, has a perpendicular fall from the top of a mountain, of more than fix hundred feet. Being very narrow, it appears at a diftance like a white garter fufpended in the air.

$A$ few Indians inhabit round the eaftern borders of this lake; fuppofed to be the remains of the Algonkins, who formerly poffeffed this country, but who have been nearly extirpated by the Iroquois of Canada. Lake Superior has uear forty rivers that fall into it, fome of which are of a confiderable fize. On the fouth fide of it is a remarkable point or cape, of about fixty miles in length, called Point Chegomegan. It might as properly be termed a peninfula, as it is nearly feparated from the continent, on the eaft fide, by a narrow bay, that extends from eaft to weft. Canoes have but a hort portage acrofs the inthmus, whereas if they coaft it round, the voyage is more than an hundred miles.

About that diftance to the wert of the cape juft defcribed, a confiderable river falls into 


\section{(131)}

into the lake, the head of which is compored of a great affemblage of fmall ftreams. This river is remarkable for the abundance of virgin copper that is found on and near its banks. A metal which is met with alfo in feveral other places on this coaft. I obferved that many of the fmall iflands, particularly thofe on the eaftern Mores, were covered with copper ore. They appeared like beds of copperas, of which many tuns lay in a fmall fpace.

A company of adventurers from England began, foon after the conqueft of Cana$\mathrm{da}$, to bring away fome of this metal, but the diftracted fituation of affairs in America has obliged them to relinquirh their fcheme. It might in future times be made a very advantageous trade, as the metal which cofts nothing on the fpot, and requires but little expence to get it on board, could be conveyed in boats or canoes through the Falls of St. Marie to the Inle of St. Jofeph, which lies at the bottom of the Straights near the entrance into Lake Huron; from thence it might be put on board larger veffels, and in them tranfported acrofs that lake to the Falls of Niagara; there being carried by land aK 2 crofs 


\section{( 132$)$}

crols the Portage, it might be conveyed without much obftruction to Quebec. The cheapnefs and eafe with which any quantity of it may be procured, will make up for the length of way that it is neceffary to tranfport it before it reaches the fea-coaft, and enable the proprietors to fend it to foreign markets on as good terms as it can be exported from other countries.

$\therefore$ Lake Superiorabounds with variety of fifh, the principal and beft are the trout and furgeon, which may be caught at almoft any feafon in the greateft abundance. The trouts in gencral weigh about twelve pounds, but fome are caught that exceed fifty. Befides thefe, a fpecies of white firh is taken in great quantities here, that refemble a thad in their Thape, but they are rather thicker, and lefs bony; they weigh about four pounds each, and are of a delicious tafte. The beft way of catching thefe firh is with a net; but the trout might be taken at all times with the hook. There are likewife many forts of frialler fifh in great plenty here, and which may be taken with eafe; among thefe is a fort refembling a herring, that are generally made ufe of as a bait for the trout. Very fmall 


\section{( 133 )}

fmall crabs, not larger than half a crown piece, are found both in this and Lake Michegan.

This lake is as much affeeted by forms as the Atlantic Ocean; the waves run as high, and are equally as dangerous to Thips. It difcharges its waters from the fouth-eaft corner, through the Straights of St. Marie. At the upper end of thefe Straights ftands a fort that receives its name from them, commanded by Monf. Cadot, a French Canadian, who being proprietor of the foil, is ftill permitted to keep poffeffion of it. Near this fort is a very ftrong rapid, againft which, though it is impoffible for canoes to afcend, yet when conducted by careful pilots, they might pafs down without danger.

Though Lake Superior, as. I have before obferved, is fupplied by near forty rivers, many of which are confiderable ones, yet it does not appear that one-tenth part of the waters which are conveyed into it by thefe rivers are carried off at this evacuation. How fuch a fuperabundance of water can be difpofed of, as it muft certainly be by fome means or other, without which the circumference of the lake would be continually enlarging, 


\section{( 334$)$}

larging, I know not: that it does not empty itfelf, as the Mediterranean Sea is fuppofed to do, b; an under current, which perpetually counteracts that near the furface, is certain; for the ftream which falls over the rock is not more than five or fix feet in depth, and the whole of it paffes on through the Straights into the adjaceni lake; nor is it probable that fo great a cruantity can be abforbed by exhalations; confequently they. inuft find a paffage through fome fubterranean cavities, deep, unfathomable, and never to be explored.

The Falls of St. Marie do not defcend perpendicularly as thofe of Niagara or St. Anthony do, but confift of a Rapid which continues near three quarters of a mile, over which canoes well piloted might pafs.

At the bottom of thefe Falls, nature has formed a moft commodious ftation for catching the firh which are to be found there in immenfe quantities. Perfons ftanding on the rocks that lie adjacent to it, may take with dipping nets, about the months of September and October, the white filh before-mentioned; at that feafon, together with feveral other fpecies, they croud up to this fpot in fuch 


\section{( 135.$)$}

fuch amazing thoals, that enough may be taken to fupply, when properly cured, thoufands of inhabitants throughout the year.

The Straights of St. Mirie are about forty miles long, bearing fouth-eaft, but varying much in their.breadth. The current between the Falls and Lake Huron is not fo rapid as might be expected, nor do they prevent the navigation of thips of burden as far up as the inland of St. Jofeph.

It has been obferved by travellers that the entrance into Lake Superior, from thefe Straights, affords one of the moft pleafing profpects in the world. The place in which this might be viewed to the greateft advantage, is juft at the opening of the lake, from whence may be feen on the left, many beautiful little iflands that extend a confiderable way before you; and on the right, an agreeable fucceffion of fmall points of land, that project a little way into the water, and contribute, with the inlands, to render this delightful bafon (as it might be termed) ralm and fecure from the ravages of thofe tempeftuous winds by which the adjoining lake is frequeritly troubled.

Lalze 


\section{( $\left.{ }^{3} 6\right)$}

Lake Huron, into which you now enter from the Straights of St. Marie, is the next in magnitude to Lake Superior. It lies between forty-two and forty-ix degrees of north latitude, and feventy-nine and eightyfive degrees of weft longitude. Its thape is nearly triangular, and its circumference about one thoufand miles.

On the north fide of it lies an ifland that is remarkable for being near a hundred miles in length, and no more than eight miles broad. This ifland is known by the name of Manataulin, which fignifies a Place of Spirits, and is confidered by the Indians as facred as thofe already mentioned in Lake Superior.

About the middle of the fouth-weft fide of this lake is Saganaum $s y$. The capes that feparate this bay from the lake, are about eighteen miles diftant from each other; near the middle of the intermediate fpace ftand two illands, which greatly tend to facilitate the paffage of canoes and finall veffels, by affording them Thelter, as without this fecurity it would not be prudent to venture acrofs fo wide a fea; and the coafting round the bay wauld make the voyage long and

tedious. 


\section{(137)}

tedious. This bay is about eighty miles in length, and in general about eighteen or twenty miles broud.

Nearly half way between Saganaum Bay and the north-weft corner of the lake lies another; which is termed Thunder Bay. The Indians, who have frequented thefe parts from time immemorial, and every European traveller that has paffed through it, have unanimounly agreed to call it by this name, on account of the continual thunder they have always obferved here. The bay is about nine miles broad, and the fame in length, and whilf I was paffing over it, which took me up near twenty-four hours, it thundered and lightened during the greateft part of the time to an exceffive degree.

There appeared to be no vifible reafon for this that I could difcover, nor is the country in general fubject to thunder; the hills that ftood around were not of a remarkable height, neither did the external parts of them feem to be covered with any fulphureous fubftance: But as this phænomenon mult originate from fome natural caufe, I conjecture that the Shores of the bay, or the adjacent mountains, are either impregnated with an uncommon 


\section{$(138)$}

quantity of fulphureous matter, or contain fome metal or mineral apt to attract in a great degree the electrical particles that are hourly' borne over them by the paffant clouds. But the folution of this, and thofe other philofophical remarks which cafually occur throughout thefe pages, I leave to the difcuffion of abler beads.

The firh in Lake Huron are much the fame as thofe in Lake Superior. Some of the land on its banks is very fertile, and proper forcultivation, but in other parts it is fandy and barren. The promontory that feparates this lake from Lake Michegan, is compofed of a vaft plain, upwards of one hundred miles long, but varying in its breadth, being from ten to fifteen miles broad. This track, as I have before obferved, is divided into almoft an equal portion between the Ottowaw and Chipéway Indians. At the northeaft corner this lake has a communication with Lake Michegan, by the Straights of Michillimackinac already defcribed:

I had like to have omitted a very extraordinary circumftance relative to thefe Straights. According to obfervations made by the French, whilft they were in poffeffion 


\section{( 139$)$}

of the fort, although there is no diurnal flood or ebb to be perceived in thefe waters, yet from an exact attention to their ftate, a periodical alteration in them has been difcovered. It was obferved that they arofe by gradual, but almoft imperceptible degrees till they had reached the height of about three feet. This was accomplimed in feven years and a half; and in the fame fpace they as gently decreafed, till they had reached their former fituation; fo that in fifteen years they had completed this inexplicable revolution. At the time I was there the truth of there obfervations could not be confirmed by the Englinh, as they had then been only a few years in poffeffion of the fort; but they all agreed that fome alteration in the limits of the Straights was apparent. All thefe lakes are fo affected by the winds, as fometimes to have the appearance of a tide, according as they happen to blow, but this is only temporary and partial.

A great number of the Chipéway Indians. live fcattered around this lake, particularly near Saganaum Bay. On its banks are found an amazing quantity of the fand cherries, and in the adjacent country nearly the fame. 


\section{(140)}

fruits as thofe that grow about the other lakes.

From the Falls of St. Marie I leifurely proceeded back to Michillimackinac, and arrived there the beginning of November 1767 , having been fourteen months on this extenfive tour, travelled near four thoufand miles, and vifited twelve nations of Indians lying to the weft and north of this place. The winter fetting in foon after my arrival, I was obliged to tarry there till the June following, the navigation over Lake Huron for large veffels not being open, on account of the ice, till that time. Meeting here with fociable company, I paffed thefe months very agreeably, and without finding the hours tedious.

One of my chief amufements was that of filhing for trouts. Though the Straights were covered with ice, we found means to make holes thro' it, and letting down ftrong lines. of fifteen yards in length, to which were fixed three or four hooks baited with the fmall firh before defcribed, we frequently caught two at a time of forty pounds weight each; but the common fize is from ten . to twenty pounds. Thefe are moft delicious: food. The method of preferving them dur : 


\section{(14t)}

ing the three months the winter generally lafts, is by hanging them up in the air; and in one night they will be frozen fo hard, that they will keep as well as if they were cured with falt.

I have only pointed out in the plan of my travels the circuit I made from my leaving Michillimackinac till $\dot{I}$ arrived again at that fort. "Thofe countries that lie nearer to the colonies have been fo often and fo minutely defcribed, that any further account of them would be ufelefs. I thall therefore only give my readers in the remainder of my journal, as I at firft propofed, a defcription of the other great lakes of Canada, many of which I have navigated over, and relate at the fame time a few particular incidents that I truft will not be found inapplicable or unentertain ing.

In June I 768 I left Michillimackinac, and returned in the Gladwyn Schooner, a veffel of about eighty tons burthen, over Lake Huron to Lake St. Claire, where we left the Ship, and proceeded in boats to Detroit. This lake is about ninety miles in circumference, and by the way of Huron River, which runs from the fouth corner of Lake Huron, receives 


\section{(142)}

receives the waters of the three great lakes; Superior, Michegan, and Huron. Its form is rather round, and in fomc places it is deep enough for the navigation of large veffels, but to wards the middle of it there is a bar of fand, which prevents thofe that are loaded from paffing over it. Such as are in ballaft only may find water fufficient to carry them quite through; the cargoes, however, of fuch as are freighted muft be taken out, and after being tranfported acrofs the bar in boats, reMipped again.

The river that runs from Lake St. Claire to Lake Erie (or rather the Streight, for thus it might be termed from its name) is called Detroit, which is in French, the Streight. It runs nearly fouth, has a gentle current, and depth of water fufficient for fhips of confiderable burthen. The town of Detroit is fituated on the weftern banks of this river, about nine miles below Lake St. Claire.

Almoft oppofite, on the eaitern more, is the village of the ancient Hurons: a tribe of Indians which has been treated of by fo many writers, that adhering to the reftrictions I have laid my felf under of only defcribing places and people little known, or incidents that have paffed 


\section{(143)}

paffed unnoticed by others, I thall omit giving a defcription of them. A miffionary of the order of Carthufian Friars, by permiflion of the bihop of Canada, refides amo.ng them.

The banks of the River Detroit, both abov: and below thefe towns, are covered with fettlements that extend more than twenty miles; the country being exceedingly fruitful, and proper for the cultivation of wheat, Indian corn, oats, and peas. It has alfo many fpots of fine pafturage; but as the inhabitants, who are chiefly French that fubmitted to the Englifh government after the conqueft of thefe parts by General Amherit, are more attentive to the Indian trade than to farming, it is but badly cultivated.

The town of Detroit contains upwards of one hundred houfes. The ftreets are fomewhat regular, and have a range of very convenient and handfome barracks, with a fpacious parade at the fouth end. On the weft fide lies the king's garden belonging to the governor, which is very well laid out and kept in good order. The fortifications of the town confift of a ftrong ftockade made of round piles, fixed firmly in the ground, and lined with 


\section{(144)}

with palifades. Thefe are defended by fome fmall baftions, on which are mounted a few indifferent cannon of an insonfiderable fize, juft fufficient for its defence againft the Indians, or an enemy not provided with artillery.

The garrifon, in time of peace, confifts of two hundred men commanded by a field officer, who acts as chief magiftrate under the governor of Canada. Mr. Turnbull, captain of the 6oth regiment or Royal Americans, was commandant when I happened to be there. This gentleman was defervedly efteemed and refpected both by the inhabitants and traders for the propriety of his conduct; and I am happy to have an opportunity of thus publickly making my acknowledgments to him, for the civilities I received from him during my ftay.

In the year 1762 , in the month of July, it rained on this town and the parts adjacent, a fulphureous water of the colour and confiftence of ink ; fome of which being collected into bottles, and wrote with, appeared perfectly intelligible on the paper, and anfwered every purpofe of that ufeful liquid. Soon after, the Indian wars already fpoken of, 


\section{$\left(145^{\circ}\right)$}

of, broke out in thefe parts. I mean not to fay that this incident was ominous of them, notwithftanding it is well known that innumerable well attefted inftances of extraordinary phænomena happening before extraordinary events, have been recorded in almoft every age by hiftorians of veracity; I only relate the circumftance as a fact of which I was informed by many perfons of undoubted probity, and leave my readers, as I have hitherto done, to draw their own conclufions from it.

Pontiac, under whom the party that furprifed Fort Michillimackinac, as related in the former part of this work, aced, was an enterprifing chief or head-warrior of the $\mathrm{Mi}$ ames. During the late war between the Englifh and the French he had been a fleady friend to the latter, and continued his inveteracy to the former even after peace had been concluded between thefe two nations. Unwilling to put an end to the depredations he had been fo long engaged in, he collected an army of confederate Indians, confifting of the nations before enumerated, with an intention to renew the war. However, inflead of openly attacking the Englifh fettlements, 


\section{(146)}

he laid a fcheme for taking by furprize thofe forts on the extremities which they had lately gained poffeffion of.

How well the party he detached to take Fort Michillimackinac fucceeded, the reader already knows. To get into his hands Detroit, a place of grcater confequence, and much better guarded, required greater refolution, and more confummate art. He of courfe took the management of this expedition on himfelf, and drew near it with the principal body of his troops. He was however prevented from currying his defigns into execution by an apparently trivial and unforefeen circumftance. On fuch does the fate of mighty Empires frequently depend!

The town of Detroit, when Pontiac formed his plan, was garrifoned by about three hundred men commanded by Major Gladwyn, a gallant officer. As at that time every appearance of war was at an end, and the Indians feemed to be on a friendly footing, Pontiac approached the Fort without exciting any fufpicions in the breaft of the governor or the inhabitants. He encamped at a little diftance from it, and fent to let the commandant know that he was come to trade; 


\section{( 147$)$}

and being defirous of brizhtening the chain of peace between the Englin and his nation, defired that he and his chiefs might be admitted to hold a council with him. The governor Atill unfufpicious, and not in the leaft doubting the fincerity of the Indians, granted their general's requeft, and fixed on the next morning for their reception.

The evening of that day, an Indian woman. who had been employed by Major Gladwyn to make him a pair of Indian thoes, out of curious elk-1kin, brought them home. The Major was fo pleafed with them, that, intending thefe as a prefent for a friend, he ordered her to take the remainder back, and make it into others for himfelf. He then directed his fervant to pay her for thofe the had done, and difmiffed her. 'The woman went to the door that led to the ftreet, but no further; the there loitered about as if the had not finithed the bufinefs on which the came. A fervant at length obferved her, and afked her why the ftaid there; the gave him, however, no anfwer.

Some thort time after, the governor himfelf faw her; and enquired of his fervant what occafioned her ftay. Not being able 


\section{( 14.8$)$}

to get a fatisfactory anfwer, he ordered the woman to be called in. Wher the came into his prefence he defired to know what was the reafon of her loitering about, and not haftening home before the gates were fhat, that fhe might complete in due time the work he had given her to do. She told him, after much hefitation, that as he had always behaved with great goodnefs towards her, the was unwilling to take away the remainder of the fkin, becaufe he put fo great a value upon it; and yet had not been able to prevail upon herfelf to tell him fo. He then arked her, why the was more reluctant to do fo now, than the had been when the made the former pair. With increafed reluctance the anfwered, that the never thould be able to bring them back.

His curiofity being now excited, he infifted on her difelofing to him the fecret that feemed to be ftruggling in her bofom for utterance. At laft, on receiving a promife that the intelligence the was about to give him flould not turn to hic: prejudice, and that if it appeared to be beneficial the finould be rewarded for it, the informed tim, that at the council to be lield with the Indians the following day, Pon-

tias 


\section{( 149 )}

tiac and his chicfs intended to murcer him; and after having inaffacred the garrifon and inhabitants, to plunder the town. That for this purpoie all the chicfs who were to be admitted into the council-room had cut their guns thort, fo that they could conceal them under their blankets; with which, at a fignal given by their general on delivering the belt, they were all to rife up, and infantly to fire on him and his attendants. Having effected this they wore immediately to ruh in to the town, where they would find themfelves fupported by a great number of their warriors, that were to come into it during the fitting of the council, under pretence of tracing, but privately armed in the fame manner. Having gained from the woman every neceffary particular relative to the plot, and alfo the means by which the acquired a knowledge of them, he difmiffed her with injunctions of fecrecy, and a promife of fulfilling on his part with punctuality the engagements he had entered into.

The intelligence the governor had juft received, gave him great uneafinefs; and he immediately confulted the officer who was next to him in command on the fubject. But that 


\section{( 150$)$}

that gentleman confidering the information as a ftory invented for fome artful purpofes, advifed him to pay no attention to it. This conclufion however had happily no weight with him. He thought it prudent to conclude it to be true, till he was convinced that it was not fo; and therefore, without revealing his fufpicions to any other perfon, he took every needful precaution that the time would admit of. He walked round the fort during the whole night, and faw himfelf that every centinel was on duty, and every weapon of defence in proper order.

As he traverfed the ramparts which lay neareft to the Indian camp, he heard them in high feftivity, and, little imagining that their plot was difcovered, probably pleafing themfelves with the anticipation of their iuccefs. As foon as the morning dawned, he ordered all the garrifon under arms; and then imparting his apprehenfions to a few of the principal officers, gave them fuch directions as he thought neceffary. At the fame time he fent round to all the traders, to inform them, that as it was expected a great number of Indians would enter the town that day, who might be inclined to plunder, he defired they 


\section{( $15 \mathrm{I})$}

they would have their arms ready, and repel every attempt of that kind.

About ten o'clock, Pontiac and his chiefs arrived; and were conducted to the councilchamber where the governor and his principal officers, each with piftols in their belts, awaited his arrival. As the Indians paffed on, they could not help obferving that a greater number of troops than ufual were drawn up on the parade, or marching about. No fooner were they entercd, and feated on the Rins prepared for thcm, than Pontiac afked the governor on what occafion his young men, meaning the foldiers, were thus drawn up, and parading the ftreets. He received for anfwer, that it was only intended to keep them perfect in their exercife.

The Indian chief-warrior now began his fpeech, which contained the ftrongeft proferfions of friendihip and good-will towards the Englifh; and when he came to the delivery of the belt of wampum, the particular mode of which, according to the woman's information, was to be the fignal for his chiefs to fire, the governor and all his attendants drew their fwords half-way out of their fcabbards; and the foldiers at the fame inftant made a clatter- 


\section{( 152$)$}

ing with their arms before the doors, which had been purpofely left open.. Fontiac, though one of the boldeft of men, immediately turned pale, and trembled; and inflead of giving the belt in the manner propofed, delivered it according to the ulual way. His chiers, who had impatiently expected the fignal, looked at each other with aftonithment, but continued quiet, waiting the refult.

The governor in his turn made a fpeech; but initead of thanking the great warrior for the profeifions of friendfhip he had juft uttered, he accufed him of being a traitor. He told him that the Englifh, who knew every thing, were convinced of his treachery and villainous defigns; and as a proof that they were well acquainted with his moft fecret thoughts and intentions, he ftepped towards the Indian chief that fat neareft to him, and drawing afide his blanket difcovered the fhortened firelock. This entirely difconcerted the Indians, and fruftrated their defign.

He then continued to tell them, that as he had given his word at the time they defires: an audience, that their perfons thould be fafe, he would hold his promife inviolable, thongh they fo litile deferved it. However he advifé 


\section{( 153$)$}

vifed them to make the beft of their way out of the fort, leit his young men, on being acquainted with their treachcrous purpofes, thould cut every one of them to pieces. Pontiac endeavoured to contradict the accufation, and to make excufes for his fufpicious conduct; but the governor, fatisfied of the falfity of his proteftations, would not liften to him. The Indians immediately left the fort, but inftead of being fenfible of the governor's generous behaviour, they threw off the mank, and the next day made a regular attack upon it.

Major Gladwyn has not efcaped cenfure for this miftaken lenity; for probably had he kept a few of the principal chiefs prifoners, whilft he had them in his power, he might have been able to ha've brought the whole confederacy to terms, and have prevented a war. But he atoned for this overfight, by the gallant defence he made for more than a year, amidft a variety of difcouragements.

During that period fome very fmart 1kirmirhes happened hetween the befiegers and the ga:rifon, of which the following was the principal and moft bloody. Captain Delzel, a brave officer, prevailed on the governor to give 


\section{( 154 )}

give him the command of about two hundred men, and to permit him to attack the enemy's camp. This being complied with, he fallied from the town before day-break; but Pontiac, receiving from fome of his fwiftfooted warriors, who were conftantly employed in watching the motions of the garrifon, timely intelligence of their defign, he collected together the choiceft of his troops, and met the detachment at fome diftance from his camp, near a place fince called BloodyBridge. As the Indians were vaftly fuperior in numbers to captain Delzel's party, he was foon overpowered and driven back. Being now nearly furrounded, he made a vigorous effort to regain the bridge he had juft croffed, by which alone he could find a retreat; but in doing this he loft his life, and many of his men fell with him. However, Major Rogers, the fecond in command, affifted by Lieutenant Breham, found means to draw off the mattered remains of their little army, and conducted them into the fort.

Thus confiderably reduced, it was with difficulty the major could defend the town; notwithftanding which, hę held out againft the Indians till he was relieved, as after this they 


\section{( 155$)$}

they made but few attacks on the place, and only continued to blockade it.

The Gladwyn Schooner (that in which I afterwards took my paffage from Michillimackinac to Detroit, and which I fince learn was loft with all her crew on the Lake Erie, through the obftinacy of the commander, who could not be prevailed upon to take in fufficient ballaft) arrived about this time near the town with a re-inforcement and neceffary fupplies. But before this veffel could reach the place of its deftination, it was moft vigorounly attacked by a detachment from Pontiac's army. The Indians furrounded it in their canoes, and made great havock among the crew. At length the captain of the fchooner with a confiderable number of his men being killed, and the favages beginning to climb up its fides from every quarter, the lieutenant (Mr. Jacobs; who afterwards commanded, and was loft in it) being determined that the ftores rhould not fall into the enemy's hands, and feeing no other alternative, ordered the gunner to fet fire to the powder room, and blow the hip up. This order was on the point of being exccuted, when a chief of the Hurons, who underitood 


\section{( 156 )}

the Englifh language, gave out to his friends the intention of the commander. On receiving this intelligence the Indians hurried down the fides of the thip with the greateft precipitation, and got as far from it as poffible; whillt the commander immediately took advantage of their confternation, and arrived without any further obftruction at the town.

This feafonable fupply gave the garrifon frem fpirits; and Pontiac being now convinced that it would not be in his power to reduce the place, propofed an accommodation; the governor wihing as much to get rid of fuch troublefome enemies, who obftructed the intercourfe of the traders with the neighbouring nations, liftened to his propofals, and having procured advantageous terms, agreed to a peace. The Indians foon after feparated, and returned to their different provinces; nor have they fince thought proper to difturb, at leaft in any great degree, the tranquillity of thefe parts.

Pontiac henceforward feemed to have laid afide the animofity he had hitherto borne towards the Englim, and apparently became their zealous friend. To reward this new attachment, and to infure a continuance of it, 


\section{( 157 )}

it, government allowed him a handfome penfion. But his reftlefs and intriguing fpirit would not fuffer him to be grateful for this allowance, and his conduct at length grew. fufpicious; fo that going, in the year 1767 , to hold a council in the country of the Illinois, a faithful Indian, who was either commiffioned by one of the Englifh governors, or inftigated.by the love he bore the Englim nation, attended him as a fpy; and being convinced from the Speech Pontiac made in the council that he fill retained his former prejudices againft thofe for whom he now profeffed a friendhip, he plunged his knife into his heart, as foon as he had done fpealsing, and laid him dead on the fpot.

But to return from this digreffion.

Lake Erie receives the waters by which it is fupplied from the three great lakes, through the Straights of Detroit, that lie at its northweft corner. This lake is fituated between forty-one and forty-three degrees of north latitude, and between feventy-eight and eighty-three degrees of weft longitude. It is near three hundred miles long from eaft to weft, and about forty in its broadeft part:

- and a remarkable long narrow point lies on 


\section{( 158$)$}

its north fide, that projects for feveral miles into the lake towards the fouth-eaft.

- There are feveral iflands near the weft end of it fo infefted with rattle-fnakes, that it is very dangerous to land on them. It is impoffible that any place can produce a greater number of all kinds of thefe reptiles than this does, particularly of the water-fnake. The lake is covered near the banks of the inlands with the large pond-lily; the leaves of which lie on the furface of the water fo thick, as to cover it entirely for many acres together; and on each of thefe lay, when I parfed over it, wreaths of water-fnakes banking in the fun, which amounted to mvriads.

The moft remarkable of the different pecies that infert this lake, is the hiffingfnake, which is of the fmall fpeckled kind, and about eighteen inches long. When any thing approaches it, it flattens itfelf in a moment, and its fpots, which are of various dyes, become vifibly brighter through rage; at the fame time it blows from its mouth with great force a fubtile wind, that is reported to be of a naufeous fmell; and if drawn in with the breath of the unwary traveller, will infallibly bring on a decline, that in a few months 


\section{( 159$)$}

months muft prove mortal, there being no remedy yet difcovered which can counteract its baneful influence.

The ftones and pebbles on the fhores of this lake are moft of them tinged, in a greater or lefs degree, with fpots that refemble brafs in their colour, but which are of a fulphureous nature. Small pieces, about the fize of hazle-nuts, of the fame kind of ore are found on the fands that lie on its banks, and under the water.

The navigation of this lake is efteemed more dangerous than any of the others on account of many high lands that lie on the borders of it, and project into the water in a perpendicular direction for many miles together; fo that whenever fudden ftorms arife, canoes and boats are frequently loft, as there is no place for them to find a Phelter.

This lake difcharges its waters at the north-eaft end, into the River Niagara, which runs north and fouth, and is about thirtyfix miles in length; from whence it falls into Lake Ontario. At the entrance of this river, on its eaftern fhore, lies fort Niagara; and, about eighteen miles further up, thofe remarkable 


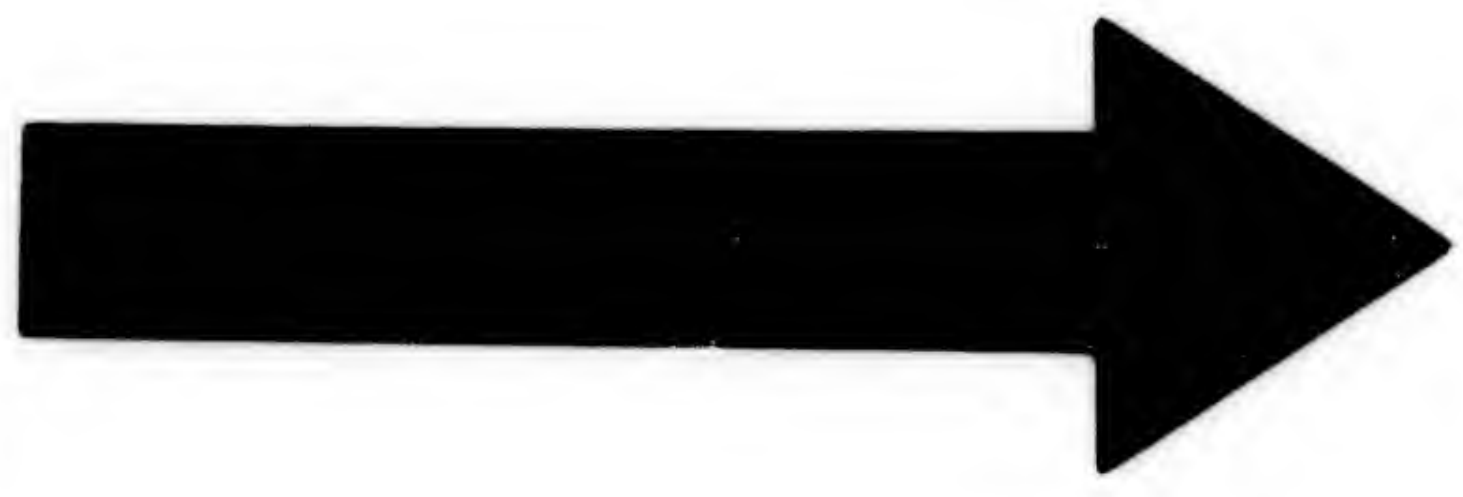




\section{IMAGE EVALUATION TEST TARGET (MT-3)}
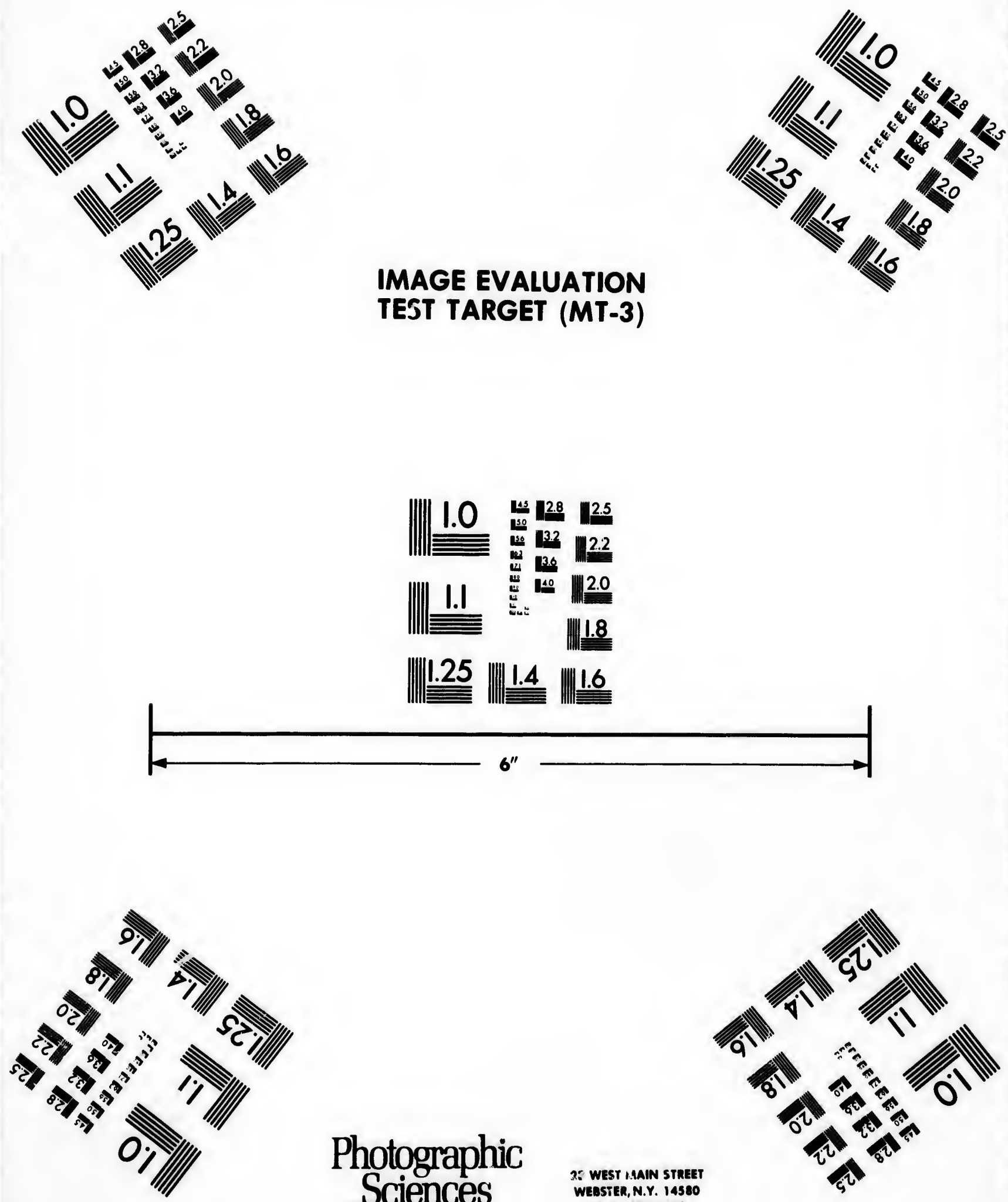

Photographic Sciences Corporation

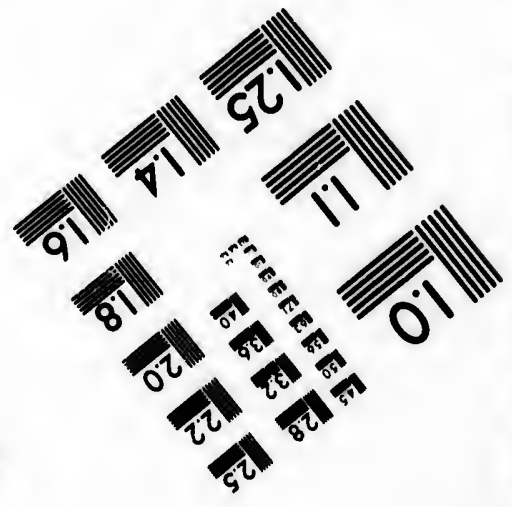





\section{( 160$)$}

markable Falls which are efteemed one of the moft extraordinary productions of nature at prefeni known.

As thefe have been vifited by fo many travellers, and fo frequently defcribed, I thall omit giving a particular defcription of them, and only obferve, that the waters by which they are fupplied, after taking their rife near two thoufand miles to the north-weft, and paffing through the Lakes Superior, Michegan, Furon, and Erie, during which they have been receiving conftant accumulations, at length rufh down a ftupendous precipice of one huridred and forty feet perpendicular; and in a ftrong rapid, that extends to the diftance of eight or nine miles below, fall nearly as much more: this River foon after empties itfelf into Lake Ontario.

The noife of thefe Falls might be heard an amazing way. I could plainly diftinguinh them in a calm morning more than twenty miles. Others have faid that at a particular time, and when the wind fits fair, the found of them reaches, fifteen leagues.

The land about the Falls is exceedingly, hilly and uneven, but the greaten part of 


\section{( 16 I )}

that on the Niagara River is very good, efpecially for grafs and pafturage.

Fort Niagara ftands nearly at the entrance of the weft end of Lake Ontario, and on the eaft part of the Straights of Niagara. It was taken from the French in the year I 759 by the forces under the command of Sir William Johnfon, and at prefent is defended by a confiderable garrifon.

Lake Ontario is the next, and leaft of the five great lakes of Canada. Its fituation is between forty-three and forty-five degrees of latitude, and between feventy-fix and feventy-nine degrees of weft longitude. The form of it is nearly oval, its greateft length being from north-eaft to fouth-weft, and in circumference about fix hundred miles. Near the fouth-caft part it receives the waters of the Ofwego River, and on the north-eaft difcharges itfelf into the River Cataraquit. Not far from the place where it iffues, Fort Frontenac formerly ftood, which was taken from the French during the laft war, in the year I 758, by a fmall army of Provincials under Colonel Bradftreet.

At the entrance of Ofwego River ftands a fort of the fame name, garrifoned only at prefent 


\section{$(162)$}

prefent by an inconfiderable party. This fort was taken in the year $175^{6}$ by the French, when a great part of the garrifon, which confifed of the late Shirley's and Pepperil's regiments, were maffacred in cold blood by the favages.

In Lake Ontario are taken many forts of firh, ainong which is the Ofwego Bafs, of an excellent flavour, and weighing about three or four pounds. There is alfo a fort called the Cat-head or Pout, which are in general very large, fome of them weighing eight or ten pounds; and they are efteemed a rare dinh when properly dreffed.

On the north-weft parts of this lake, and to the fouth-eaft of Lake Huron, is a tribe of Indians called the Miffifauges, whofe town is denominated Toronto, from the lake on which it lies, but they are not very numerous. The country about Lake Ontario, efpecially the more north and eaftern parts, is compofed of good land, and in time may make very flourißhing fettlements.

The Oniada Lake, fituated near the head of the River Ofwego, receives the waters of Wood-Creek, which takes its rife not far from the Mohawks River. Thefe two lie fo adjacent to each other, that a junstion is effected 


\section{$\left(\begin{array}{ll}163\end{array}\right)$}

fected by nuices at Fort Stanwix, about twelve miles from the mouth of the former. This lake is about thirty miles long from eait to weft, and near fifteen broad. The co!ntry around it belongs to the Oniada Indians.

Lake Champlain, the next in fize to Lake Ontario, and which lies nearly eaft from it, is about eighty miles in length, north and fouth, and in its broadeft part fourteen. It is well ftored with fin, and the lands that lie on all the borders of it, or about its rivers, very good.

Lake George, formerly called by the French Lake St. Sacrament, lies to the fouthweft of the laft-mentioned Lake, and is about thirty-five miles long from north-eaft to fouth-weft, but of no great breadth. The country around it is very mountainous, but in the vallies the land is tolerably good.

When thefe two lakes were firft difcovered, they were known by no other name than that of the Iroquois Lakes; and I believe in the firft plans taken of thofe parts were fo denominated. The Indians alfo that were then called the Iroquois, are fince known by the name of the Five Mohawk Nations, and the Mohawks of Canada. In the late war,

$$
\mathrm{M}_{2} \text { the }
$$




\section{( 164$)$}

the former, which confift of the Onondagoes, the Oniadas, the Senecas, the Tufcarories, and the Iroondocks, fought on the fide of the Englin: the latter, which are called the Cohnawahgans, and St. Francis Indians, joined the French.

$A$ vaft tract of land that lies between the two laft-mentiond lakes and Lake Ontario, was granted in the year 1629 by the Plymouth Company, under a patent they had received from King James I. to Sir Ferdinando Gorges, and to Captain John Mafon, the head of that family, afterwards diftinguifhed from others of the fame name by the Mafons of Connecticut. The countries fpecified in this grant are faid to begin ten miles from the heads of the rivers that run from the eaft and fouth into Lake George and Lake Champlain; and continuing from thefe in a direct line weftward, extend to the middle of Lake Ontario; from thence, being bounded by the Cataraqui, or the river of the Iroquois, they take their courfe through Montreal, as far as Fort Sorell, which lies at the junction of this river with the Richlieu; and from that point are inclofed by the laft-mentioned river till it returns back to the two lakes.

This 


\section{( 165$)$}

This immenfe fpace was granted, by the name of the Province of Laconia, to the aforefaid gentlemen, on fpecified conditions, and under certain penalties; but none of thefe amounted, in cafe of omiffion in the fulfilment of any part of them to forfeiture, a fine only could be exacted.

On account of the continual wars to which thefe parts have been fubject, from their fituation between the fettlements of the Englim, the French, and the Indians, this grant has been fuffered to lie dormant by the real proprietors. Notwithftanding which, feveral towns have been fettled fince the late war, on the borders of Lake Champlain, and grants made to different people by the governor of New York of part of thefe territories, which are now become annexed to that province.

There are a great number of lalses on the north of Canada, between I-abrador, Lake Superior, and Hudfon's Bay, but thefe are comparatively fmall. As they lie out of the track that I purfued, I thall only give a fummary account of them. The mof wefterly of thefe are the Lakes Nipifing and Tamifcaming. The firft lies at the head of the French river, and runs into Lake Huron; 


\section{(166)}

the other on the Ottawaw River, which empties itfelf into the Cataraqui, at Montreal. Thefe lakes are each about one hundred miles in circumference.

The next is Lake Miftaffin, on the head of Rupert's River, that falls into James's Bay. This lake is fo irregular from the large points of land by which it is interfesed on every fide, that it is difficult either to defcribe its Thape, or to afcertain its fize. It however appears on the whole to be more than two hundred miles in circumference.

Lake St. John, which is about eighty miles round, and of a circular form, lies on the Saguenay River, directly north of Quebec; and falls into the St. Lawrence, fomewhat north-eaft of that city. Lake Manikouagone lies near the head of the Black River, which empties itfelf into the St. Lawrence to the eaftward of the laft-mentioned river, near the coaft of Labrade and is about fixty miles in circumference. Lake Pertibi, Lake Wincktagan, Lake Etchelaugon, and Lake Papenouagane, with a number of other fmall lakes; lie near the heads of the Buftard River to the north of the St. Lawrence. Many others, which it is unneceffary to particularize here, 


\section{( 167$)$}

are alfo found between the Lakes Huron and Ontario.

The whole of thofe I have enumerated, amounting to upwards of twenty, are within the limits of Canada ; and from this account it might be deduced, that the northern parts of North America, through thefe numerous inland feas, contain a greater quantity of water than any other quarter of the globe.

In October I $768 \mathrm{I}$ arrived at Bofton, having been abfent fror. it on this expedition two years and five months, and during that time travelled near feven thoufand miles. From thence, as foon as I had properly digefted my journal and charts, I iet out for England, to communicate the difcoveries I had made, and to render them boneficial to the kingdom. But the profecution of my plans for reaping thefe advantages have hitherto been obftructed by the unhappy divifions that have been fomented between Great Britain and the Colonies by their mutual enemies. Should peace once more be reftored, I doubt not but that the countries I have defcribed will prove a more abundant fource of riches to this nalion than either its Eaft or Weft Indian fettlements; and I thall not only pride 


\section{( 168$)$}

pride myfelf, but fincerely rejoice in being the means of pointing out to it fo valuable an acquifition.

I cannot conclude the account of my extenfive travels, without expreffing my gratitude to that beneficent Being who invifibly protected me through thofe perils which unavoidably attend folong a tour among fierce and untutored favages.

At the fame time let me not be accufed of vanity or prefumption, if I declare that the motives alledged in the Introduction of this work, were not the only ones that induced me to engage in this arduous undertaking. My views vere not folely confined to the advant that might accrue, either to myfelf, or the community to which I belonged; but nobler purpofes contributed principally to urge me on.

The confined ftate, both with regard to civil and religious improvements, in which fo many of my fellow creatures remained, aroufed within my bofom an irrefiftible incli-. nation to explore the almoft unknown regions which they inhabited; and, as a preparatory ttep towards the introduction of more polined manners, and more humane fentiments, 


\section{( 169$)$}

to gain a knowledge of thcir language, cuftoms, and principles.

I confers that the little benefit too many of the Indian nations have hitherto received from their intercourfe with thofe who denominate themfelves chriftians, did not tend to encourage my charitable purpofes; yet, as many, though not the generality, might receive fome benefit from the introduction among them of the polity and religion of the Europeans, without retaining only the errors or vices that from the depravity and perverfion of their profeffors are unhappily attendant on thefe, I determined to perfevere.

Nor could I flatter myiclf that I hould be able to accomplifh alone this grcat defign; however, I was willing to contribute as much as lay in my power towards it. In all public undertakings would every one do this and furnifh with alacrity his particular thare towards it, what ftupendous works might not be completed!

It is true that the Indians are not without fome fenfe of religion, and fuch as proves that they worfhip the Great Creator with a degree of purity unknown to nations who 


\section{(170)}

have grcater opportunities of improvement; but their religious principles are far from be.ing fo faultlefs as defcribed by a learned writer, or unmixed with opinions and ceremonies that greatly leffen their excellency in this point. So that could the doctrines of genuine and vital chriftianity be introduced among them, pure and untainted as it flowed from the lips of its Divine Inftitutor, it would certainly tend to clear away that fuperfitious or idolatrous drofs by which the rationality of their religious tenets are obfcured. Its mild and beneficent precepts would likewife conduce to foften their implacable difpofitions, and to refine their favage manners; an event moft defirable; and happy thall I efteem myfelf if this publication thall prove the means of pointing out the path by which falutary inftructions may be conveyed to them, and the converfion, though but of a few, be the confequence.

Conclufion of the J OUR NAL, \&c.

O F 
O F T H E

ORIGIN, MANNERS, CUSTOMS, RELIGION, AND LANGUAGE O F T H E

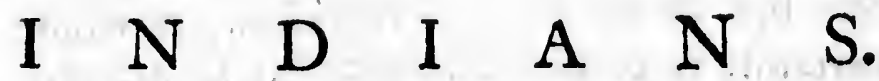

\section{H A P T E R I.}

$$
\text { of their O R I G I N. }
$$

THE means by which America received 1 its firft inhabitants, have, fince the the time of its difcovery by the Europeans, been the fubject of numberlefs difquifitions. Was I to endeavour to collect the different opinions and reafonings of the various writers that have taken up the pen in defence of their conjectures, the enumeration would much exceed the bounds I have prefcribed. myfelf, and oblige me to be lefs explicit on points of greater moment.

From 


\section{(172)}

From the obfcurity in which this debate is enveloped, through the total difufe of letters among every nation of Indians on this extenfive con inent; and the uncertainty of oral tradition at the diftance of fo many ages, I fear, that even after the moft minute inveftigation we thall not be able to fettle it with any great degree of certainty. And this apprehenfion will receive additional force, when it is confidered that the diverfity of language which is apparently diftinct between moft of the Indians, tends to afcertain that this population was not effected from one particular country; but from feveral neighbouring ones, and completed at different periods:

Moft of the hiftorians or travellers that have treated on the American Aborigines difagree in their fentiments relative to them. Many of the ancients are fuppofed to have known that this quarter of the globe not only exifted, but alfo that it was inhabited. Plato in his Timæus has afferted, that beyond the ifland which he calls Atalantis, and which according to his defcription was fituated in the weftern Ocean, there were a great number 


\section{( 173 )}

number of other iflands, and behind thofe a vaft continent.

Oviedo, a celebrated Spanifh author of a much later date, has made no fcruple to affirm that the Antilles are the famous Herperides fo often mentiuned by the poets; which are at length reftored to the kings of Spain, defcendents of King Hefperus, who lived upwards of three thoufand years, ago, and from whom thefe inlands received their name.

Two other Spaniards, the one Father Gregorio Garcia, a Dominican, the other Father Jofeph De Acofta, a Jefuit, have written on the origin of the Americans.

The former; who had been employed in the miffions of Mexico and Peru, endeavoured to prove from the traditions of the Mexicans, Peruvians, and others, which he received on the fpot; and from the variety of characters, cuftoms, languages, and religion obfervable in the different countries of the new world, that different nations had contributed to the peopling of it.

The latter, Father De Acofta, in his examination of the means liy which the firft Indians of America might have found a paf- 


\section{( 174$)$}

fage to that continent, difcredits the conclufions of thofe who have fuppofed it to be by fea, becaufe no ancient author has made mention of the compars: and concludes, that it mult be either by the north of Afia and Europe, which adjoin to each other, or by thofe regions that lie to the fouthward of the Straights of Magellan. He alfo rejects the affertions of fuch as have advanced that it was peopled by the Hebrews.

John De Laët, a Flemifh writer, has controverted the opinions of thefe Spanim fathers, and of many others who have written on the fame fubject. The hypothefis he endeavours to eftablifh, is, that America was certainly peopled by the Scythians or Tartars; and that the tranfmigration of thefe people happened foon after the difperfion of Noah's grandfons. He undertakes to thow, that the moft northern Americans have a greater refemblance, not only in the features of their countenances, but alfo in their complexion and manner of living, to the Scythians, Tartars, and Samoides, than to any other nations:

In anfwer to Grotius, who had afferted that fome of the Norwegians paffed into America 


\section{( 17.5$)$}

America by way of Greenland, and over - a vaft continent, he fays, that it is well known that Greenland was not difcovered till the year 964 , and both Gomera and Herrera inform us that the Chichimeques were fettled on the lake of Mexico in 721 . He adds, that thefe favages, according to the uniform tradition of the Mexicans who difpoffeffed them, came from the country fince called New Mexico, and from the neighbourhood of $\mathrm{Ca}$ lifornia; confequently North America muft have been inhabited many ages before it could receive any inhabitants from Norway by way of Greenland.

It is no lefs certain, he obferves, that the real Mexicans founded their empire in 902, after having fubdued the Chichimeques, the Otomias, and other barbarous nations, who had taken poffeffion of the country round the Lake of Mexico, and each of whom fpoke a language peculiar to theinfelves. The real Mexicans are likewife fuppofed to come from fome of the countries that he near California, and that they performed their journey for the moft part by land; of courfe they could not come from Norway. 


\section{(176)}

De Lae further adds, that though fome of the inhabitants of North America may have entered it from the north-weft, yet, as it is related by Pliny and fome other writers, that on many of the inlands near the weftern coaft of Africa, particularly on the Canaries, fome ancient edifices were feen, it is highly probable from their being now deferted, that the inhabitants may have paffed over to Ámerica; the paffage being neither long nor diffcult. 'This migration, according to the cal-' culation of thofe authors, muft have happened more than two thoufand years ago, at a time when the Spaniards were much troubled by the Carthaginians; from whom having obtained a knowledge of Navigation, and the conftuction of fhips, they might have retired to the Antilles, by the way of the weftern ifles, which were exactly half way on their voyage:

He thinks alfo that Great Britain, Ireland, and the Orcades were extremely proper to admit of a fimilar conjecture. As a proof; he inferts the following paffage from the hiftory. of Wales, written by Dr. David Powel in the year II 70. 


\section{( 1777$)$}

This hiftorian fays, that Madoc, one of the fons of Prince Owen Gwynnith, being difgufted at the civil wars which broke out between his brothers, after the death of their father, fitted out feveral veffels, and having provided them with every thing neceffary for a long voyage, went in queft of new lands to. the weftward of Ireland; there he difcovered very fertile countries, but deftitute of inhabitants; when landing part of his people, he returned to Britain, where he raifed new Levies, and afterwards tranfported them to his colony.

The Flemin author then returns to the Scythians, between whom and the Americans he draws a parallel. He obferves that feveral nations of them to the north of the Cafpian Sea led a wandering life; which, as well as many other of their cuftoms, and way of living, agrees in many circumftances with the Indians of America. And though the refemblances are not abfolutely perfect, yet the emigrants even before they left their own country, differed from each other, and went not by the fame name. Their change of abode affected what remained. 


\section{( 178$)$}

He further fays, that a fimilar likenefs exifts between feveral American nations, and the Samoeides who are fettled, according to the Rulfian accounts, on the great River Oby. And it is more natural, continues he, to fuppofe that Colonies of thefe nations pafled over to America by croffing the icy fea on theix Aledges, than for the Norwegians to travel all the way Grotius has marked out for them.

This writer makes many other remarks that are equally fenfible, and which appear to be juit; but he intermixes with thefe fome that are not fo well-founded.

Emanuel de Moraez, a Portugueze, in his hiftory of Brazil, afferts that America has been wholly peopled by the Carthaginians and Ifraclites. He brings as a proof of this affertion the difcoveries the former are known to have made at a great diftance beyond the coaft of Africa. The progrefs of which being put a ftop to by the fenate of Carthage, thofe who happened to be then in the newly difcovered countries, being cut off from all communication with their countrymen, and deftitute of many neceffaries of life, fell into a flate of barbarifm: As to the Ifraelites, 
this author thinks that nothing but circumcifion is wanted in order to conftitute a perfect refemblance between them and the Brazilians.

George De Hornn, a learned Dutchman, has likewife written on this fubject. He fets out with declaring, that he does not believe it poffible America could have been peopled before the flood, confidering the thort fpace of time which elapfed between the creation of the world and that memorable event. In the next place he lays it down as a principle, that after the deluge, men and other terreftrial animals penetrated into that country both by fea and by land; fome through accident, and fome from a formed delign. That birds got thither by flight; which they were enabled to do by refting on the rocks and inlands that are fcattered about in the ocean.

He further obferves, that wild beafts may have found a free paffage by land; and that if we do not meet with horfes or catile (to which he might have added elephants, camels, rhinoceros, and beafts of many other kinds) it is becaure thofe nations that paffed thither, were either not acquainted with $\mathrm{N}_{2}$ their 


\section{$(-180)$}

their ure, or had no convenience to tranfport them.

Having totally excluded many nations that others have admitted as the probable firft fettlers of America, for which he gives fubftantial reafons, he fuppofes that it began to be peopled by the north; and maintains that the primitive colonies fpread themfelves by means of the ifthmus of Panama through the whole extent of the continent.

He believes that the firf founders of the Indian Colonies were Scythians. That the Phonicians and Carthaginians afterwards got footing in America acrofs the Atlantic Ocean, and the Chinefe by way of the Pacific. And that other nations might from time to time have landed there by one or other of thefe ways, or might poffibly have been thrown on the coaft by tempefts: fince, through the whole extent of that Continent, both in its northern and fouthern parts, we meet with undoubted marks of a mixture of the northern nations with thofe who have come from other places. And lafty, that fome Jews and Chriftians might have been carried there by fuch like events, but that this mult have happened 


\section{( $\mathrm{I} 8 \mathrm{r})$}

port

pened at a time when the whole of the new world was already peopled.

After all, he acknowledges that great difficulties attend the determination of the queftion. Thefe, he fays, are occafioned in the firft place by the imperfect knowledge we have of the extremities of the globe, towards the north and fouth pole; and in the next place to the havock which the Spaniards, the firft difcoverers of the new world, made among its moft ancient monuments; as witnefs the great double road betwixt Quito and Cuzco, an undertaking fo fupendous, that even the moft magnificent of thofe executed by the Romans cannot be compared to it.

He fuppofes alfo another migration of the Phonicians, than thofe already mentioned, to have taken place; and this was during a three years voyage made by the Tyrian fleet in the fervice of King Solomon. He afferts on the authority of Jofephus, that the port at which this embarkation was made lay in the Mediterranean. The fleet, he adds, went in queft of elephants teeth and peacocks, to the weftern Coalt of Africa, which is Tarfin, then to Ophir for gold, which 


\section{( 182$)$}

is Haité, or the illand of Hifpaniola ; and in the latter opinion he is fupported by Columbus, who, when he difcovered that ifland, thought he could trace the furnaces in which the gold was refined.

To thefe migrations, which preceded the Chriftian æra, he adds many others of a later date from different nations, but thefe I have not time to enumerate. For the fame reafon I am obliged to pafs over numberlefs writers on this fubject; and fhall content myfelf with only giving the fentiments of two or three more.

The firft of thefe is Pierre De Charlevoix, a Frenchman, who in his journal of a voyage to North America, made fo lately as the year 1720, has recapitulated the opinions of a variety of authors on this head, to which he has fubjoined his own conjectures. But the latter cannot without fome difficulty be extracted, as they are fo interwoven with the paffages he has quoted, that it requires much attention to difcriminate them.

He feems to allow that America might have received its firft inhabitants from Tartary and Hyrcania. This he confirms, by obferving that the lions and tigers which are found 


\section{( 183$)$}

found in the former, muft have come from thofe countries, and whofe paffage ferves for a proof that the two hemifpheres join to the northward of Afia. He then draws a corroboration of this argument, from a ftory he fays he has often heard related by Father Grollon, a French jefuit, as an undoubted matter of fact.

This Father, after having laboured fome time in the miffions of New France, paffed over to thofe of China. One day as he was travelling in Tartary, he met a Huron woman whom he had formerly known in Ca-

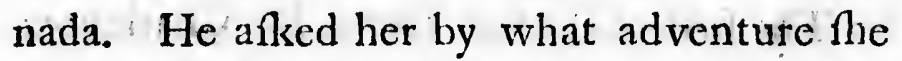
had been carried into a country fo diftant from her own. She made anfwer, that having been taken in war, the had been conducted from nation to nation, till the had reached the place at which the then was.

Monfieur Charlevoix fays further, that he had been affured, another Jefuit, pafing through Nantz in his return from China, had related much fuch another affair of a Spanilh woman from Florida. She alfo had been taken by certain Indians, and given to thofe of a more diftant country, and by there again to another nation, till having thus been fuccer- 


\section{( 184$)$}

fucceffively paffed from country to country, and travelled through regions extremely cold, The at laft found herfelf in Tartary. Here the had married a Tartar, who had attended the conquerors into China, where the was then fettled.

He acknowledges as an allay to the probability of thefe ftories, that thofe who had failed fartheft to the eaftward of Afia, by purfuing the Coaft of Jeffo or Kamtfchatka, have pretended that they had perceived the extremity of this Continent; and from thence have concluded that there could not poffibly be any communication by land. But he adds that Francis Guclla, a Spaniard, is faid to have afferted, that this feparation is no more than a fraight, about one hundred - miles over, and that fome late voyages of the Japonefe give grounds to think that this fraight is only a bay, above which there is a paffage over land.

He goes on to obferve, that though there are few wild beafts to be met with in North America, except a kind of tygers without fpots, which are found in the country of the Iroquoife, yet towards the tropics there are lions and real tygers, which, notwithftanding, might 


\section{$\left(185^{\circ}\right)$}

might have conse from Hyrcania and Tartary; for as by advancing gradually fouthward they met with climates more agrceable to their natures, they have in time abandoned the northern countries.

He quotes both Solinus and Pliny to prove that the Scythian Anthropophagi once depopulated a great extent of country, as far as the piomontory Tabin; and alfo an author of later date, Mark Pol, a Venetian, who, he fays, tells us, that to the north eaft of China and Tartary, there are vaft uninhabited countries, which might be fufficient to confirm any conjectures concerning the retreat of a great number of Scythians into America.

To this he adds, that we find in the antients the names of fome of thefe nations. Pliny fpeaks of the Tabians; Solinus mentions the Apuleans, who had for neighbours the Maffagetes, whom Pliny fince affures us to have entirely difappeared. Ammianus Marcellinus exprefsly tells us, that the fear of the Anthropophagi obliged feveral of the inhabitants of thofe countries to take refuge elfewhere. From all thefe authorities Monr. Charlevoix concludes, that there is at leaft 


\section{( 186$)$}

room to conjecture that more than one nation in America had a Scythian or Tartarian original.

He finifhes his remarks on the authors he has quoted, by the following obfervation: It appears to me that this controverfy may be reduced to the two following articles; firt, how the new world might have been peopled, and fecondly, by whom, and by what means it has been peopled.

Nothing, he afferts, may be more eafily anfwered than the firf. America might have been peopled as the three other parts of the world have been." Many difficulties have been formed on this fubject, which have been deemed infolvable, but which are far from being fo. The inhabitants of both hemifpheres are certainly the defcendents of the fame father; the common parent of mankind received an exprefs command from heaven to people the whole world, and accordingly it has been peopled.

To bring this about it was neceffary to - vercome all difficulties that lay in the way, and they have been got over. Were thefe difficulties greater with refpect to peopling the extremities of Afia, Africa, and Europe, 


\section{( 187$)$}

ation

ori-

-s he

n: It

be firft, peowhat

afily lave the lave een rom nifthe ind to it

to y, fe ig e, or

or the tranfporting men into the iflands which lie at a confiderable diftance from thofe continents, than to pafs over into America? certainly not.

Navigation, which has arrived at fo great perfection within thefe three or four centuries, might poffibly have been tisuie perfect in thofe early ages than at this day. Who can believe that Noah and his immediate defcendents knew lefs of this art than we do? That the builder and pilot of the largeft (hip that ever was, a hip that was formed to traverfe an unbounded ocean, and had fo many hoals and quick-fands to guard againf, Should be ignorant of, or fhould not have communicated to thofe of his defcendents who furvived him, and by whofe means he was to execute the order of the Great Creator; I fay, who can believe he fhould not have communicated to them the art of failing upon the ocean, which was not only more calm and pacific, but at the fame time confined within its ancient limits?

Admitting this, how eafy is it to pafs, $\mathbf{e x}$ clufive of the paffage already defcribed, by land from the coaft of Africa to Brazil, from the Canaries to the weftern Iflands, and from

them 


\section{( 188$)$}

them to the Antilles? From the Britifh ifles, or the coaft of France, to Newfoundland, the paffage is neither long nor difficult; I might fay as much of that from China to Japan; from Japan, or the Philippines, to the ifles Mariannes; and from thence to Mexico.

There are iflands at a confiderable diftance from the continent of Afia, where we have not been furprized to find inhabitants, why then fhould we wonder to meet with people in America ? Nor can it be imagined that the grandfons of Noah, when they were obliged to feparate and fpread themfelves, in conformity to the defigns of God, over the whole earth, fhould find it abfolutely impoffible to people almoft one half of it.

- I have been more copious in my extrats from this author than I intended, as his reafons appear to be folid, and many of -his obfervations juft. From this encomium, however, I muft exclude the ftories he has introduced of the Huron and Floridan women, which I think I might venture to pronounce fabulous.

I thall only add, to give my readers a more comprehenfive view of Monf. Charlevoix's differ- 


\section{$(189)$}

ifles, d, the might apan: ifles o.

tance have why eople $t$ the liged conwhole le to

rats reaoblowtronen, ance

hore ix's Per-

differtation, the method he propofes to come at the truth of what we are in fearch of. The only means by which this can be done, he fays, is by comparing the languages of the Americans with the different nations, from whence we might fuppofe they have peregrinated. If we compare the former with thofe words that are confidered as primitives it might poffibly fet us upon fome happy difcovery. And this way of afcending to the original of nations, which is by far the leait equivocal, is not fo difficult as might be imagined: We have had and ftill have, travellers and miffionaries who have attained the languages that are fpoken in all the provinces of the new world; it would only be neceffary to make a collection of their grammars and vocabularies, and to collate them with the dead and living languages of the old world, that pafs for originals, and the fimilarity might eafily be traced. Even the different dialects, in fpite of the alterations they have undergone, Atill retain enough of the mother tongue to furnilh confiderable lights.

Any-enquiry into the manners, cuftoms, xeligian, or traditions of the Americans, in order 


\section{(190)}

order to difcover by that means their origin, he thinks would prove fallacious, : A difquifition of that kind he obferves is only capable of producing a falfe light; more likely to da'zzle, and to make us wander from the right path, than to lead us with certainty to the point propofed.

Ancient traditions are effaced from the minds of fuch as either have not, or for feveral.ages have been without, thofe helps that are neceffary to preferve them. And in this fituation is full one half of the world. New events and new arrangement of things; give rife to new traditions, which efface the former, and are themfelves effaced in return. After one or two centuries have paffed, there no longer remain any traces of the firt traditions; and thus we are involved in a ftate of uncertainty.

He concludes with the following remarks, among many others. Unforefeen accidents, tempefts, and thipwrecks, have certainly contributed to people every habitable part of the world : and ought we to wonder, after this, at perceiving certain refemblances, both of perfons and manners, between nations that are moft remote from each other, when we find 


\section{( I9I)}

rigin, ifqui-

pable

daz-

right

the

the

$r$ fe-

helps

id in

rorld.

ings,

e the

turn.

here

tra-

Pate

rrks, nts, onthe his, of hat we

find fuch a difference between thofe that border on one another? As we are deftitute of hiftorical monuments, there is nothing, I repeat it, but a knowledge of the primitive languages that is capable of throwing any light upon thefe clouds of impenetrable darknefs.

By this enquiry we fhould at leaft be fatisfied, among that prodigious number of various nations inhabiting America, and differing fo much in languages from each other, which are thofe who make ufe of words totally and entirely different from thofe of the old world, and who confequently muft be reckoned to have paffed over to America in the earlieft ages, and thofe, who from the analogy of their language with fuch as are at prefent ufed in the three other parts of the globe, leave room to judge that their migration has been more recent, and which ought to be attributed to Shipwrecks, or to fome accident fimilar to thofe which have been fpoken of in the courfe of this treatife.

I Thall only add the opinion of one author more before I give my own fentiments on the fubject, and that is of James Adair, Efq; who refided forty years among the Indians, 


\section{$(.192)$}

and publimed the hiftory of them in the year 1772. In his learned and fyftematical hiftory of thofe nations, inhabiting the weftern parts of the molt fouthern of the American colonies, this gentleman without hefitation pronounces that the American Aborigines are defcended from the Ifraelites, either whilft they were a maritime power, or foon after their general captivity.

This defcent he endeavours to prove from their religious rites, their civil and martial cuftoms, their marriages, their funeral ceremonies, their manners, language, traditions, and from a variety of other particulars. And fo complete is his conviction on this head, that he fancies he finds a perfect and indirputable finilitude in each. Through all there I have not time to follow him, and that therefore only give a few extracts to how on what foundation he builds his conjectures, and what degree of credit he is entitled to on this point.

He begins with obferving, that though fome have fuppofed the Americans to be defcended from the Chinefe, yet neither their religion, laws, or cuftoms agree in the leat - th thofe of the Chinefe; which fufficiently 


\section{(193)}

year iftory parts colopro$s$ are whilft after from artial cereions, And head, ndifthere that von ures, d to ugh be heir leaft intly ves

proves that they are not of this line. Befides, as our beft thips are now almoft half a year in failing for China (our auther does not here recollect that this is from a high northern latitude, acrofs the Line, and then back again greatly to the northward of it, and not directly. athwart the Pacific Ocean for only one hundred and eleven degrees) or from thence to Europe, it is very unlikely they thould attempt fuch dangerous difcoveries, with their fuppofed fmall veffels; againft rapid currents, and in dark and fickly Monfoons.

He further remarks, that this is more particularly improbable, as there is reafon to believe that this nation was unaequainted with the ufe of the loadftone to direct their courfe. China, he fays, is about eight thoufand miles diftant from the American continent, which is twice as far as acrofs the Atlantic Ocean. And we are not informed by any ancient writer of their maritime Akill, or fo much as any inclination that way, befides fmall coafting voyages. The winds blow, likewife, with little variation from eaft to wert within the latitudes thirty and odd, north and fouth; and therefore thefe could 


\section{( 194$)$}

not drive them on the Amcrican coaft, it lying directly contrary to fuch a courfe.

Neither could perfons, according to this writer's account, fail to America from the north by the way of Tartary or Ancient Scythia ; that from its fituation never having been or can be a maritime power: and it is utterly impracticable, he fays, for any to come to America by fea from that quarter. Befides, the remaining traces of their religious ceremonies and civil and martial cuftoms are quite oppofite to the like veftiges of the Old Scythians. Even in the moderate northern climates there is not to be feen the leaft trace of any ancient ftately buildings, or of any thick fettlements, as are faid to remain in the lefs healthy regions of Peru and Mexico. And feveral of the Indian nations affure us, that they croffed the Miffifippi before they made their prefent northern feitlements ; which, connected with the former arguments, he concludes will fufficiently explode that weak opinion of the American Aborigines being lineally defcended from the Tartárs or ancient Scythians.

Mr. Adair's reafons for fuppofing that the Americans derive their origin from the Jews are,

Firft, 


\section{(195)}

Firft, bccaufe they are divided into tribes, and have chiefs over them as the Ifraelites had.

Secondly, becaufe, as by a ftriat permanent divine precept, the Hebrew nation were ordered to worhip, at Jerufalem, Jehovah the true and living God, fo do the Indians, ftiling him Yohewah. The ancient Heathens, he adds, it is well known worhipped a plurality of Gods, but the Indians pay their religious devoirs to the Great beneficent fupreme holy Spirit of Fire, who refides, as they think, above the clouds, and on earth alfo with unpolluted people. They pay no adnration to images, or to dead perfons, neither to the celeftial luminarics, to evil fpirits, nor to any created beings whatever.

Thirdly, becaufe, agrecable to the theocracy or divine government of Ifrael, the Indians think the deity to be the immediate head of their ftate.

Fourthly; becaufe, as the Jews believe in the miniftration of angels, the Indians alfo believe that the higher regions are inhabited by good fpirits.

Fifthly, becaufe the Indian language and dialects appear to have the very idiom and

Firft,

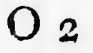

genius 


\section{( 196$)$}

genius of the Hebrew. Their words and fentences being expreffive, concife, emphatical, fonorous, and bold; and often, both in letters, and fignification, are fynonimous with the Hebrew language.

Sixthly, becaufe they count their time after the manner of the Hebrews.

Seventhly, becaufe in conformity to, or after the manner of the Jews, they have their prophets, high-priefts, and other religious orders.

Eighthly, becaufe their feftivals, fafts, and religious rites have a great refemblance to thofe of the Hebrews.

Ninthly, becaufe the Indians, before they go to war, have many preparatory ceremonies of purification and fafting, like what is recorded of the Ifraelites.

Tenthly, becaufe the fame tafte for orna- ments, and the fame kind are made ufe of by the Indians, as by the Hebrews.

Thefe and many other arguments of a fimilar nature, Mr. Adair brings in fupport of his favourite fyftem; but I hould imagine, that if the Indians are really derived from the Hebrews, arong their religious ceremonies, on which he chiefly feems to build his hypothefis, 


\section{(197)}

Is and mphaooth in us with

me af-

to, or e their ligious

ts, and ince to

re they eremowhat is

ornaof by

a fimiort of agine, from remoild his hefis,

hypothefis, the principal, that of circumcifion, would never have been laid afide, and its very remembrance obliterated.

Thus numerous and diverfe are the opinions of thofe who have hitherto written on this fubject! I thall not, however, either endeavour to reconcile them, or to point out the errors of each, but proceed to give my own fentiments on the origin of the Americans; which are founded on conclufions drawn from the moft rational arguments of the writers I have mentioned, and from my own obfervations: the confiftency of thefe I thall leave to the judgment of my Readers.

The better to introduce my conjectures on this head, it is neceffary firft to afcertain the diftances between America and thofe parts of the habitable globe that approach neareft to it.

The Continent of America, as far as we can judge from all the refearches that have been made near the Poles, appèars to be entirely feparated from the other quarters of the world. That part of Europe which approaches neareft to it, is the coaft of Greenland, lying in about feventy degrees of north latitude; 


\section{( 198$)$}

latitude; and which reaches within twelve degrees of the coaft of Labrador, fituated on the north-eaft borders of th continent. This coaft of Guinea is the neareft part of Africa ; which lies about eighteen hundred and fixty milcs north-eaft from the Brazils. The moft eaftern coaft of Afia, which extends to the Korean Sea on the north of China, projects north-eaft through eaftern Tartary and Kamfchatka and Siberia, in about fixty degrees of north latitude. Towards which the weflern coafts of America, from California to the ftraights of Annian, extend nearly north-weft, and lie in about forty fix degrees of the fame latitude.

Whether the continent of America ftretches any farther north than thefe ftraights, and joins to the eaftern parts of Afia, agreeable to what has been afferted by fome of the writers I have quoted, or whether the lands that have been difcovered in the intermediate parts are only an archipelirgo of iflands verging towards the oppoifte continent, is not yet afcertained.

It being, however, certain that there are many confiderable inlands which lie between the extremities of Afia and America, viz.

Japon, 
Japon, Yefo or Jedfo, Gama's Land, Behring's lle, with many others difcovered by Tfchirikow, and befides thefe, from fifty degrees ncrth there appearing to be a clufter of iflands that reach as far as Siberia, it is probable from their proximity to America, that it received its firft inhabitants from therm.

This conclufion is the moft rational I am able to draw, fuppofing that fince the Aborigines got footing on this continent, no extraordinary or fudden change in the pofition or furface of it has taken place, from inundations, earthquakes, or any revolutions of the earth that we are at prefent unacquainted with.

To me it appears highly improbable that it Thould have been peopled from different quarters, acrofs the Ocean, as others have afferted. From the fize of the Mips made ufe of in thofe early ages, and the want of the compafs; it cannot be fuppofed that any maritime nation would by choice venture over the unfathomable Ocean in fearch of diftant continents. Had this however been attempted; or had America been firft accidentally pcopled from hips freighted with paffengers of both fexes which were driven by ftrong eafter- 


\section{( 200$)$}

ly winds acrofs the Atlantic, thefe fetilers muft have retained fome traces of the language of tine country from whence they migrated; and this fince the difcovery of it by the Europeans muft have been made out. It alfo appears extraordinary that feveral of thefe accidental migrations, as allowed by fome, and thefe from different parts, should have taken piace.

Upon the whole, after the moft uritical enquiries, and the matureft deliberation, I am of opinion, that America received its firft inhabitants from the north-eaft, by way of the great Archipelago juft menticned, and from thefe alone. But this might have been effected at different times, and from various parts: from Tartary, China, Japon, or Kamfchatka, the inhabitants of thefe places refembling each other in colour, features, and Shape; and who, before fome of them acquired a knowledge of the arts and fciences, might have likewife refembled each other in their manners, cuftoms, religion, and language.

The only difference between the Chinefe nation and the Tartars lies in the cultivated ftate of the one, and the unpolimed fituation of the others. The former have be- 


\section{(201)}

ers

cone a commercial people, and dwell in houfes formed into regular towns and cities; the latter live chiefly in tents, and rove about in different hords, without any fixed abode. Nor can the long and bloody wars thefe two nations have been engaged in, exterminate their hereditary fimilitude. The prefent family of the Chinefe emperors is of Tartarian extraction; and if they were not fenfible of fome claim befides that of conqueft, fo numerous a people would fcarcely fit quiet under the dominion of frangers.

It is very"evident that fome of the manners and cuftoms of tine American Indians refem. ble thofe of the Tartars; and I make no doubt but that in fome future æra, and this not a very diftant one, it will be reduceed to a certainty, that during fome of the wars between the Tirtars and the Chinefe, a part of the inbabitants of the northern provinces were driven from their native country, and took refuge in fome of the ifles before-mentioned, and from thence found their way into America. At diffcrent periods each nation might prove victorious, and the conquered by turns fly before their ccaquerors; and from hence might arife the fimilitude of

the 


\section{( 202 )}

the Indians to all thefe people, and that animolity which exifts between fo many of their tribes.

It appears plainly to me that a great fimilarity between the Indian and Chinefe is confpicuous in that particular cuftom of thaving or plucking off the hair, and leaving only a finall tuft on the crown of the head. This mode is faid to have been enjoined by the Tartarian emperors on their acceffion to the throne of China, and confequently is a further proof that this cuftom was in uff among the Tartars; to whoin, as well as the Chinefe, the Americans might be indebted for it.

Many words alfo are ufed both by the Chinefe and Indians, which have a refemblance to each other, not only in their found, but their fignification. The Clinefe call a flave, Ahungo; and the Naudoweflie Incians, whofe language from their little intercourfe with the Europeans is the leaft corrupted, term a dog, thunguhl. The former denominate one fpecies of their tea, fhoufong; the latter cail their tobacco, Thoufaffa: Many other of the words ufer by the Indians con tain 
t anif the ir

fimiefe is om of leavof the $n$ entheir confecuftom oin, as ight be by the refemfound, call a idians, courfé upted, denofong; Many s con. tain

\section{(203)}

tain the fyllables che, chaw, and chu, after the dialeat of the Chinere.

There probably might be found a fimilar connection between the language of the Tartars and the American Aborigines, were we as well acquainted with it as we are, from a commercial intercou:fe, with that of the Chinefe.

I am confirmed in thefe conjectures, by the accounts of Kamfchatka publifhed a few years ago by order of the emprefs of Rufia. The author of which fays, that the fea which divides the peninfula from America is full of iflands; and that the difance between Tfchukotfkoi-Nofs, a promontory which lies at the eaftern extremity of that country, and the coaft of Anerica, is not more than two degrees and a half of a great circle. He iurther fays, that there is the greateif reafon to fuppofe that Afia and America once joined at shis place, as the coafts of both continents spear to have been broken into capes and bays, which anfwer each other; more efpecially as the inhabitants of this part of both refemble each other in their perfons, habits, cuftoms, and food. 'Their language, indeed, he obferves, does not appear to be the fame, 


\section{(204)}

but then the inhabitants of each diftrict in Kamfchatka fpeak a language as different from each other, as from that fpoken on the oppofite coaft. Thefe obfervations, to which he adds, the fimilarity of the boats of the inhabitants of each coaft, and a remark that the natives of this part of America are wholly ftrangers to wine and tobacco, which he looks upon as a proof that they have as yet had no communication with the natives of Europe, he fays amount to little lefs than a demonfration ti. "merica was peopled from this part of Alia.

The limits of my prefent undertaking will not permit me to dwell any longer on this fubject, or to enumerate any other proofs in favour of my hypothefis. I am however fo thoroughly convinced of the certainty of it, and fo defirous have I been to obtain every teftimony which can be procured in its fupport, that I once made an offer to a private fociety of gentlemen, who were curious in fuch refearches, and to whom I had communicated my fentiments on this point, that I would undertake a journey, on receiving fuch fupplics as were needful, through the north-eaft parts of Europe and Afia to the 


\section{(205)}

Atrict in lifferent on the which the in. that the wholly ie looks yet had Europe, demonom this

ng will

on this oofs in ever fo of it, every ts fupprivate ous in ommuthat I eeiving th the to the hterior interior parts of America, and from thence to England; making, as I proceeded, fuch obfervations both on the language and manners of the people with whom I Mould be converfant, as might tend to illuftrate the doctrine I have here laid down, and to fatisfy the curiofity of the learned or inquifitive; but as this propofal was judged rather to require a national than a private fupport, it was not carried into execution.

I am happy to find, fince I formed the foregoing conclufions, that they correfpond. with the fentiments of that great and learned hiftorian Doctor Robertfon; and though, with him, I acknowledge that the inveftigation, from its nature, is fo obfcure and intricate that the conjectures I have made can only. be confidered as conjectures, and not indifputable conclufions, yet they carry with them a greater degrce of probability than the fuppofitions of thofe who affert that this continent was peopled from another quarter.

One of the Doctor's quotations from the Journals of Behring and Tfchirikow who failed from Kamfchatka about the year ${ }^{1} 74 \mathrm{I}$ in queft of the New World, appears to carry great weight with it, and to afford our conclunions 


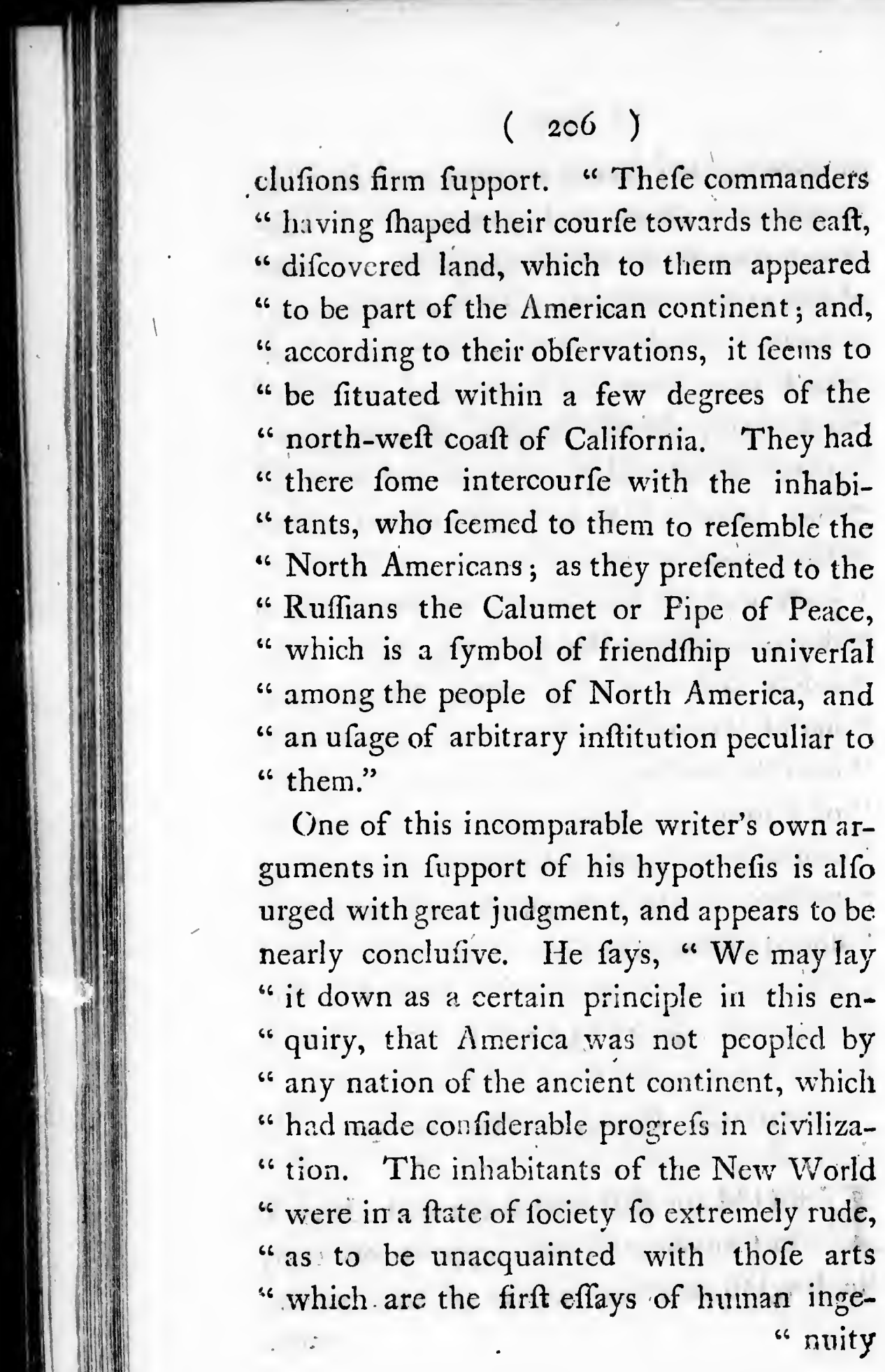


nanders

he eaft, peared $t$; and, eins to of the ey had nhabible the to the Peace, iverfal , and liar to

Wn aris alfo to be ay lay is ened by which ilizaVorld rude, arts ingeavity

\section{('207)}

" nuity in its advance towards improvement. " Even the moft cultivated nations of Ame" rica were ftrangers to many of thofe fimple " inventions, which were almoft coeval with "fociety in other parts of the world, and "were known in the earlieft periods of civil "life. From this it is manifent that the "tribes which originally migrated to Ame" rica, came off from nations which muft " have been no lefs barbarous than their " pofterity, at the time when they were firft " difcovered by the Europeans. If ever the "ufe of iron had been known to the fava"ges of America, or to their progenitors, if " ever they had employed a plough, a loom, " or a forge, the utility of thefe inventions "would have preferved them, and it is im" poff-le that they fhould have been aban" doned or forgotten."

\section{H A P. II.}

Of their Persons, Dress, छc.

HOM the firft fettlement of the French 1 in Canada, to the conqueft of it by the Englifh in 1760 , feveral of that nation,

whe. 


\section{(208)}

who had travelled into the interior parts of North America, either to trade with the Indians, or to endeavour to make converts of them, have publifhed accounts of their cuftoms, manners, \&c.

The principal of thefe are Father Louis Hennipin, Monf. Charlevoix, and the Baron Le Hontan. The firf, many years ago, publifhed fome very judicious remarks, which he was the better enabled to do by the affiftance he received from the maps and diaries of the unfortunate Monf. De la Salle, who was affaffinated whilft he was on his travels; by fome of his own party. 'That gentleman's journals falling into Father Hennipin's hands; he was enabled by them to publifh many interefting particulars relative to the Indians. But in fome refpects he fell very thort of that knowledge which it was in his power to have attained from his long refidence among them. Nor was he always (as has been already obferved) exact in his calculations, or juft in the intelligence he has given us,

The accounts publimed by the other two, partigularly thofe of Charlevoix, are very erroneovs in the geographical parts, and many: 


\section{(209)}

s: of

In -

ts of

cuf-

ouis

faron

ago,

which

affift-

laries

who

ivels;

nan's

ands;

$y$ in-

lians:

that

have

hem.

ob-

it in

two,

very

hany:

- DE

of the ftories told by the Baron are mere deIufions.

Come of the Jefuits, who heretofore travelled into thefe parts, have alfo written on this fubject; but as few, if any, of their works have been tranflated into the Englin language, the generality of readers are not benefitted by them; and, indeed, had this been done, they would have reaped but few advantages from them, as they have chiefly confined their obfervations to the religious principles of the favages, and the fteps taken for their converfion.

Since the conqueft of Canada, fome of our own countrymen, who have lived among the Indians, and learned their language, have publifhed their obfervations; however as their travels have not extended to any of the interior parts I treat of, but have only been made among the nations that border on our fettlements, a knowledge of the genuin- and uncontaminated cuftoms and manners of the Indians could not have been acquired by them.

The fouthern tribes, and thofe that have beld a confant intercoutfe with the French or Englin, cannot have preferved their man- 


\section{(210)}

ners or their cuftoms in their original purity. They could not avoid acquiring the vices with the language of thofe they converfed with; and the frequent intoxications they experienced through the baneful juices introduced among them by the Europeans, have completed a total alteration in their characters.'

In fuch as thefe, a confufed medley of principles or ufages are only to be obferved; their real and unpolluted cuftoms could be feen among thofe nations alone that have held but little communications with the provinces. Thefe $I$ found in the north-weft parts, and therefore flatter myfelf that I am able to give a more juft account of the cuftoms and manners of the Indians, in their ancient purity, than any that has been hitherto publinhed. I have made obfervations on thirty nations, and though moft of thefe have differed in their languages, there has appeared a great fimilarity in their manners, and from thefe have I endeavoured to extract the following remarks.

As I do not propofe to give a regular and ccnnected fy ftem of Indian concerns, but only to relate fuch particulars of their manners, cuftoms, 
al purity. the vices converfed ons they uices inropeans, in their

edley of bferved; could be hat have the proirth-weft at I am the curin their been hirvations of thefe here has nanners, o extract

dar and but only nanners, cuftoms,

\section{(2II)}

cuftoms, \&c. as I thought moft worthy of notice, and which interfere as little as porfible with the accounts given by other writers, I muft beg my readers to excufe their not being arranged fyftematically, or treated of in a more copious manner.

The Indian nations do not appear to me to difier fo widely in their make, colour, or confitution from each other, as reprefented by fome writers. They are in general night made, rather tall and frait, and you feldom fee any among them deformed; their $\mathrm{Kin}_{\mathrm{i}}$ is of a reddin or copper colour; their eyes are large and black, and their hair of the fame hue, but very rarely is it curled; they have good teeth, and their breath is as fweet as the air they draw in; their cheek-bones rather raifed, but more fo in the women than the men; the former are not quite fo tall as the European women, however you frequently meet with good faces and agrecable perfons among them, although they are more inclined to be fat than the other fex.

I thall not enter into a particular enquiry whether the Indians are indebted to nature, art, or the temperature of the climate for the colour of their $\mathrm{Nin}$, nor thall I quote any of isiofuco

$\mathrm{P} 2$

the 


\section{(212)}

the contradictory accounts I have read on this fubject; I thall only fay, that it appears to me to be the tincture they received origi nally from the hands of their Creator; but at what period the variation which is at pre. fent vifible both in the complexion and features of many nations took place, at what time the European whitenefs, the jetty hue of the African, or the copper caft of the American were given them, which was the original colour of the firft inhabitants of the earth, or which might be efteemed the moft perfect, I will not pretend to determine.

Many writers have afferted, that the Indians, even at the matureft period of their exiftence, are only furnifhed with hair on their heads; and that notwithftanding the profufion with which that part is covered, thofe parts which among the inhabitants of other climates are ufually the feat of this excrefcence, remain entircly free from it. Even Doctor Robertfon, through their mifreprefentations, has contributed to propagate the error; and fuppofing the remark juftly founded, has drawn feveral conclufions from it relative to the habit and temperature of their bodies, which are confequently invalid.

But 
oad on appears d origi pr ; but at pre. nd fea. t what ty hue e Amec origie earth, perfect,

the Inof their lair on ng the overed, ants of of this om it. mifrespagate juftly is from ture of nvalid. But

\section{(213)}

But from minute enquiries and a curious infpection, I am able to declare (however refpectable I may hold the authority of thefe hiftorians in other points) that their affertions are erroneous, and proceeding from the want of a thorough knowledge of the cuftoms of the Indians.

After the age of puberty, their bodies, in their natural ftate, are covered in the fame manner as thofe of the Europeans. IThe men, indeed, efteem a beard very unbecoming, and take great pains to get rid of it, nor is there any ever to be perceived on their faces, except when they grow old, and become inattentive to their appearance. Every crinous efflorefcence on the other parts of the body is held unfeemly by them, and both fexes employ much time in their extirpation.

The Nawdoweffies, and the remote nations, pluck them out with bent pieces of hatd wood, formed into a kind of nippers; whilf thofe who have communication with Europeans procure from them wire, which they twift into a fcrew or worm; applying this to the part, they prefs the rings together, and 


\section{( 214 )}

and with a fudden twich draw out all the hairs that are inclored between them.

The men of every nation differ in their drefs very little from each other, except thofe who trade with the Europeans; thefe exchange their furs for blankets, fhirts, and other apparel, which they wear as much for orrament as neseffity. The latter faften by a girdle around their waifts about half a yard of broadcloth, which covers the middle parts of their bodies. Thofe who wear Mirts never make them faift either at the wrift or collar; this would he a moft infufferable cons finement to them. They throw their blan kei loofe upon their fhoulders, and holding the upper fide of it by the two corners, with a knife in one hand, and a tobacco-pouch, pipe, \&c. in the other, thus accoutred they walk about in their villages or camps : but in their dances they feldom wear this cover. ing.

Thore aniong the then who wirh to appear gayer than the reft, pluck from their heads all the a ar except from a fpot on the top of it about the fize of a crown-piece, where it is permitted to grow to a confiderable length: on this are faftened plumes of feathers of various 


\section{(215)}

all the

rous colours with filver or ivory quills. 'The manner or cutting and ornamenting this part of the head diftinguifhes different nations from each other.

They paint their faces red and black, which they efteem as greatly ornamental. They alfo paint themfelves when they go to war; but the method they make ufe of on this occafion differs from that wherein they ufe it merely as a decoration.

The young Indians, who are defirous of excelling their companions in finery, lit the outward rim of both their ears; at the fame time they take care not to feparate them entirely, but leave the flem thus cut fill untouched at both extremities: around this fpongy fubftance, from the upper to the lower part, they twift brafs wire, till the weight draws the amputated rim into a bow of five or fix inches diameter, and drags it almoft down to the fhoulder. This decoration is efteemed to be exceffively gay and becoming.

It is alfo a common cuftom among them to bore their nofes, and wear in them pendants of different forts. I obferved that fea Anells were much worn by thofe of the interior

appear

$r$ heads

top of here it length: of va. rious 


\section{( 216$)$}

rior parts, and reikoned very ornamental; but how they procured them I could not learn: probably by their traffick with other nations nearer the fea.

They go writhout any covering for the thigh, except that before fpoken of, round the middle, which reaches down half way the thighs; but they make for their legs a fort of ftocking either of Akins or cloth : thefe are fewed as near to the thape of the leg as poffible, fo as to admit of being drawn on and off. The edges of the ftuff of which they are compofed are left annexed to the feam, and hang loofe for about the breadth of a hand: and this part, which is placed on the outfide of the leg, is generally ornamented by thofe who have any communication with Europeans, if of cloth, with ribands or lace, if of leather, with embroidery or porcupine quills curiouny coloured. Strangers who hunt among the Indians in the parts where there is a great deal of fnow, find thefe ftockings much more convenient than any others.

Their thoes are made of the Akin of the deer, elk, or buffalo: thefe, after being formetimes dreffed according to the European man. 
iental;

ld not 1 other

or the round ay the fort of efe are poffi$n$ and they feam, of $a$ on the zented with r lace, upine who where there any

\section{ff the} orneman. ner,

\section{( $\left.217^{\prime}\right)$}

ner, at others with the hair remai ing on them, are cut into moes, and fafhioned fo as to be eafy to the feet, and convenient for walking. The edges round the ankle are decorated with pieces of brafs or tin fixed around leather ftrings, about an inch long, which being placed very thick make a cheerful tinkling noife either when they walk or dance.

ii The women wear a covering of fome kind or other from the neck to the knees. Thiofe who trade with the Europeans wear a linen garment the fame as that ufed by the men; the flaps of which hang over the petticoat. Such as drefs after the ancient manner make a kind of Shift with leather, which covers the body but not the arms. Their petticoats are nuade eicher of leatiser or cloth, and reach from the waift to the knee. On their legs they wear ftockings and hoes, made and ornamented as thofe of the men.

They differ from each other in the mode of dreffing their heads, and each follow the cuftom of the nation or band to which they belong, and adhering to the form made ufe of by their anceftors from time immemorial. 


\section{(218)}

I remarked that moft of the females, who dwell on the eaft fide of the Miffffippi, decorate their heads by inclofing their hair either in ribbands, or in plates of filver : the latter is only made ufe of by the higher ranks, as it is a coftly ornament. The filver they ufe on this occafion is formed into thin plates of about four inches broad, in feveral of which they confine their hair. That plate which is neareft the head is of a confiderable width; the next narrower, and made fo as to pars a little way under the other; and in this manner they faften into each other, and, gradually tapering, defcend to the waift. The hair of the Indian women being in general very long, this proves an expenfive method.

But the women that live to the weft of the Miffiffippi, viz. the Naudoweffies, the Affinipoils, \&c. divide their hair in the middle of the head, and form it into two rolls, one againft each ear. 'Thefe rolls are about three inches long, and as large as their wrifts. They hang in a perpendicular attitude at the front of each ear, and defcend as far as the lower part of it.

The 
who

ji, de. air eihe latranks, r they plates oral of t plate lerable fo as and in $r$, and, waift. in gesenfive

veft of $s$, the e midrolls, about wrifss, at the as the

\section{(2.9)}

The women of every nation generally place a fpot of paint, about the fize of a crown piece, againft each ear; fome of them put paint on their hair, and fometimes a fmall fpot in the middle of their forehead.

The Indians, in general, pay a greater attention to their drefs and to the ornaments with which they decorate their perfons, than to the accommodations of their huts or tents. They conftruct the latter in the following fimple, and expeditious manner.

Being provided with poles of a proper length, they faften two of them acrofs, near their ends, with bands made of bark. Having done this, they raife them up, and extend the bottom of each as wide as they purpofe to make the area of the tent : they then erect others of an equal height, and fix them fo as to fupport the two principal ones. On the whole they lay Akins of the elk or deer, fewed together, in quantity fufficient to cover the poles, and by lapping over to form the door. A great number of 1 kins are fometimes required for this purpofe, as fome of their tents are very capacious. That of the chief 


\section{( 220$)$}

chief warrior of the Naudoweffies was at leaft forty feet in circumference, and very commodious.

They obferve no regularity in fixing their tents when they encamp, but place them juft as it fuits their conveniency.

The huts alfo, which thofe who ufe not tents, erect when they travel, for very few tribes haves fixed abodes or regular towns or villages, are equally fimple, and almoft as foon conftructed.

They fix fmall pliable poles in the ground; and bending them till they meet at the top and form a femircircle, then larh them together. Thefe they cover with mats made of rumes platted, or with birch bark, which they carry with them in their canoes for this purpofe.

Thefe cabins have neither chimnies nor windows; there is only a fmall aperture left. in the middle of the roof, through which the fmoke is difcharged, but as this is obliged to be ftopped up when it rains or fnows violently, the fmoke then proves exceedingly troublefome.

They lie on 1kins, generally thofe of the bear, which are placed in rows on the ground; and 


\section{(22I)}

was at d very

g their em juft

fe not ry few wns or oft as

round; he top togeade of. which or this

es nor re left. ch the ged to s viodingly

of the ound; and

and if the floor is not large enough to contain beds fufficient for the accommodation of the whole family, a frame is erected about four or five feet from the ground, in which the younger part of it neep.

As the habitations of the Indians are thus. rude, their domeftic utenfils are few in num. ber, and plain in their formation. The tools wherewith they fathion them are fo aukward and defective, that it is not only impoffible to form them with any degree of neatnefs or elegance, but the time required in the execution is fo confiderable, as to deter them from engaging in the manuacture of fuch as are. not abfolutely neceffary.

The Naudoweffies make the pots in which they boil their victuals of the black clay or ftone mentioned in my Journal; which refifts the efrects of the fire nearly as well as iron. When they roaft, if it is a large joint or a whole animal, fuch as a beaver, they fix it as Europeans do, on a fpit made of a hard wood, and placing the ends on two forked props, now and then turn it. If the piece is finaller they fpit it as before, and fixing the fpit in an erect but flanting pofition, with the meat inclining towards the fire, frequent- 


\section{$(\therefore 222)$}

ly change the fides, till every part is fufficiently roafted.

'They make their difhes in which they ferve up their meat, and their bowls and pans, out of the knotty excrefcences of the maple tree, or any other wood. They fahion their fpoons, with a tolerable degree of neatnefs (as thefe require much lefs trouble than larger utenfils) from a wood that is termed in America Spoon Wood, and which greatly refembles Box Wood.

Every tribe are now poffeffed of knives, and fteels to ftrike fire with. Thefe being fo effentially needful for the common ufes of life, thofe who have not an immediate communication with the European traders, purchafe them of fuch of their neighbours as are fituated nearer the fettlem ${ }^{\circ}$ its, and generally give in exchange for them llaves. 
It is fuffi-

hich they bowls and ces of the hey farhidegree of Is trouble at is term. ich great-

of knives, 1efe being on ufes of liate comders, purjurs as are generally

H A P.

\section{$(223)$}

At in

\section{H A P. III.}

Of their Manners, QualificatiO.N S, Eं.

WT ${ }^{\mathrm{HE}} \mathrm{N}$ the Indian wor.en fit down, they place themfelves in a decent at. titude, with their knees clofe together, but from being accuftomed to this pofture, they walk badly, and appear to be lame.

239 They have no midwives amongt them, their climate, or fome peculiar happinefs in their conftitutions, rendering any affiftance at that time unneceffary. On thefe occafions they are confined but a few hours from their ufual employments, which are commonly very laborious, as the men, who are remarkably indolent, leave to thein every kind of drudgery; even in their hunting parties the former will not deign to bring home the game, but fend their wives for it, though it lies at a very confiderable diftance.

The women place their children foon after they are born on boards ftuffed with foft mofs, fuch as is found in moraffes or meadows. 


\section{( 224$)$}

dows. The child is laid on its back in one of thefe kind of cradles, and being wrapped in Akins or cloth to keep it warm, is fecured in it by fmall bent pieces of timber.

To thefe machines they faften ftrings, by which they hang them to branches of trees; or if they find not trees at hand, faften them to a fump or ftone, whilit they tranfact any needful bufinefs. In this pofition are the children kept for fome months. When they are taken out, the boys are fuffered to go naked, and the girls are covered from the neck to the knees with a hift and a hort petticoat.

The Indian women are remarkably decent during their menftrual illnefs. Thofe nations that are moft remote from the European fettlements, as the Naudoweffies, \&c. are more particularly attentive to this point; though they all without exception adhere in fome degree to the fame cuftom.

In every camp or town there is an apartment appropriated for their retirement at this time, to which both fingle and married retreat, and feclude themfelves with the utmoft frianefs during this period from all fociety. Afterwards they purify themfelves in running 
in one rapped ecured

gs, by trees; 2 them act any re the n they to go im the a Thort

decent e natiropean cc. are point ; ere in

apartat this ied reuntmoft ociety.

running

ning ftreams, and return to their different employments.

The men on thefe occafions moft carefully avoid holding any communication with them; and the Naudoweffies are fo rigid in this obfervance, that they will not fuffer any belonging to them to fetch fuch things as are theceffary, even tire, from thefe female lunar retreats, though the want of the $m$ is attended with the greateft inconvenience. They are alfo fo fuperftitious as to think, if a pipe ftem cracks, which among them is made of wood, that the poffeffor has either lighted it at one of thefe polluted fires, or held fome converfe with a woman during her retirement, which is efteemed by them moit difgraceful and wicked.

The Indians are extremely circumfpect and deliberate in every word and aftion; there is nothing that hurries them into any intemperate warmth, but that inveteracy to their enemies which is rooted in every Indian heart, and never can be eradicated. In all other inftances they are cool, and remarkably cautious, taking care not to betray on any account whatever their emotions. If an Indian has difcovered that a friend is in danger

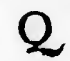

of 


\section{( 226$)$}

of being intercepted and cut off by one to whom he has rendered himfelf obnoxious, he does not inform him in plain and explicit terms of the hazard he runs by purfuing the track near which his encmy lies in wait for him, but he firft coolly afks him which way he is going that day; and having received his anfwer, with the fame indifference tells him that he has been informed that a dog lies near the fpot, which might probably do him a mifchief. This hint proves fufficiemt; and his friend avoids the danger with as much caution as if every defign and motion of his enemy had been pointed out to him.

This apathy often thews itfelf on occafions that would call forth all the fervour of a fufceptible heart. If an Indian has been abfent from his family and friends many months, either on a war or hunting party, when his wife and children meet him at fome diftance from his habitation, inftead of the affectionate fenfations that : would naturally arife in the breaft of more refined beings, and be productive of mutual congratulations, he continues his courfe without paying the leaft attention to thofe who furround him, till he arrives at his home.

He 


\section{( 227$)$}

one to xious, he explicit fuing the wait for dich way received nce tells it a dog bably do Ifficiemt ; as much n of his

occafions of a furn abfent months, when his diftance affectially arife , and be , he conthe leaft , till he

$\mathrm{He}$

He there fits down, and with the fame unconcern as if he had not been abfent a day, fmokes his pipe; thofe of his acquaintance who have followed him, do the fame; and perhaps it is feveral hours before he relates to them the incidents which bave befallen him during his abfence, though, perhaps he has left a father, brother, or fon on the field, whofe lors he ought to have lamented, or has been unfuccefsful in the undertaking that called him from home.

Has an Indian been engaged for feveral days in the chace, or any other laborious expedition, and by accident continued thus long without food, when he arrives at the hut or tent of a friend where he knows his wants may be immediately fupplied, he takes care not to thow the leaft fymptoms of inpatience, or to betray the extreme hunger by which he is tortured; but on being invited in, fits contentedly down, and fmokes his pipe with as much compofure as if every appetite was allayed, and he was perfectly at cafe; he does the fame if among ftrangers. This cuftom is frictly adhered to by every tribe, as they efteem it a proof of fortitude, $\mathrm{Q}_{2}$ and 


\section{$(2.28)$}

and thirik the reverfe would entitlc them to the appellation of old women.

If you tell an Indian that his children have greatly. fignalized themfelves againit an enemy, have taken many fcalps, and brought home many prifoners, he does not appear to feel any extraordinary pleafure on the nccafion; his unfwer generaily is, "It is well," and he makes very little further enquiry about it. On the contrary, if you inform him that his children are flain or taken prifoners, he makes no complainte, he only replies, "It does not fignify ;" and probably, for fome time at leaft, afks not how it happened.

This feeming indifierence, however, does. not proceed from an entire lupprefiron of the natural affections; for notwithftanding they are efteemed favages, I never faw among any other people greater proofs of parental or filial tenderneís; and aithough they meet their wives after a long abfence with the Stoical indifference juft mentioned, they are not in general void of conjugal affection.

Another peculiarity is obfervable in their manner of paying their vifits. If an Indian goes to vifit a particular perfon in a family, he 
he mentions to whom his vifit is intended, have and the reft of the family immediately retiring to the other end of the hut or tent, are careful not to come near enough to interrupt them during the whole of the converfation. The fame method is purfued if a man goes to pay his refpects to one of the other fex; but then he muft be careful not to let love be the fubject of his difcourfe whilft the daylight remains:

The Indians difcover an amazing fagacity, and acquire with the greateft readinefs any thing that depends upon the attention of the mind. By experience and acute obfervation, they attain many perfections to which Europeans are Atrangers. For inftance, they will crofs a foreft or a plain which is two hundred miles in breadth, and reach with great exactnefs the point at which they intend to arrive, keeping during the whole of that fpace in a direct line, without any material deviations; and this they will do with the fame eafe, whether the weather be fair or cloudy.

With equal acutenefs will they point to that part of the heavens the fun is in though it be intercepted by clouds or fogs. Befides this, they are able to purfue with incredible facility

Indian amily, he 


\section{( 230$)$}

facility the traces of man or beaft, either on leaves or grafs; and on th's account it is with great difficulty a flying enemy efcapes difcovery.

They are indebted for thefe talents not only to nature, but to an extraordinary command of the intellectual faculties, which can only be acquired by an unremitted attention, and by long experience.

'They are in general very Kappy in a retentive memory; they can recapitulate every particular that has been treated of in council, and remember the exact time when thefe were held. Their belts of wampum preferve the fubftance of the treaties they have concluded with the neigbouring tribes for ages back, to which they will appeal, an 1, iefer with as much perípicuity and readinefs as Europeans can to their written records.

- Every nation pays great refpect to old age. The advice of a father will feldom meet with an extraordinary attention from the young Indians, probably they receive it with only a bare affent; but they will tremble before a grandfather, and fubmit to his injunctions with the utmoft alacrity. The words of the ancient part of their community are efteemed 
ther on ht it is efcapes

hts not y comich can ention,

a ree every council, thefe referve ve conines 1. iefer lefs as s.

ld age. et with young a only efore a ctions of the eemed by

\section{( 231$)$}

by the young as oracles. If they take during their hunting parties any game that is reckoned by them uncommonly delicious, it is immediately prefented to the oldeft of their relations.

-They never fuffer themfelves to be overburdened with care, but live in a ftate of perfect tranquility and contentment. Being naturally indolent, if provifion juft fufficięnt for their fubfiftence can be procured with little trouble, and near at hand, they, will not go far, or take any exträordinary pains for it, though by fo doing they might acquire greater plenty, and of a more eftimable kind.

Having much leifure time they indulge this indolence to which they are fo prone, by eating, drinking, or fleeping, and rambling about in their towns or camps. But when neceffity obliges them to take the field, either to oppofe an enemy, or to procure themfelves food, they are alert and indefatigable. Many inftances of their activity on thefe occafions will be given when I treat of their wars.

The infatuating fpirit of gaming is not confined to Europe; the Indians alfo feel the bewitching impulfe, and often lofe their arms, their apparel, and every thing they are pofferfed 


\section{$(232)$}

poffeffed of. In this cafe, however, they do not follow the example of more refined gamefters, for they neither murmur nor repine; not a fretful word efcapes them, but they bear the frowns of fortune with a philofophic compofure.

The greateft blemith in their character is that favage difpofition which impels them to treat their enemies with a feverity every other nation fhudders at. But if they are this barbarous to thore with whom they are at war, they are friendly, hofpitable, and humane to thofe with whom they are at peace. It may with truth be faid of them, that they are the worft enemies, and the beft friends, of any people in the whole world.

The Indians in general are ftrangers to the paffions of jealoufy; and brand a man with folly that is diftruftful of his wife. Among fome bands the very idea is not known; as the mort abandoned of their young men very rarely attempt the virtue of married women, nor do thefe often put themfelves in the way of folicitation. Yet the Indian women in general are of an amorous temperature, and before they are married are not the lefs efteemed for the indulyence of their pafions.

Whilit 
Whilft I was among the Naudoweffies I obferved that they paid uncommon refpect to one of their women, and found on enquiry that the was intitled to it on account of a tranfaction, that in Europe would have rendered her infamous.

They told me that when the was a young woman, for at the time I faw her the was far advanced in life, the had given what they had termed a rice feaft. According to an ancient but almoft obfolete cuftom (which, as Hamlet fays, would have been honoured in the breach, than the obfervance) the invited forty of the principal warriors to her tent, where having feafted them with rice and venifon, the by turns regaled each of them with a private deffert, behind a fcrene fixed for this purpofe in the inner part of the tent.

She had the happinefs to obtain by this profufion of courtefy, the favour of her guefts, and the approbation of the whole band. So fenfible were the young Indians of her extraordinary merit, that they vied with each other for her hand, and in a very hort time one of the principal chiefs took her to wife, over whom the acquired great fway, and froin 


\section{( 234$)$}

whom the received ever after inceffant tokens of refpect and love.

It is however fcarcely once in an age that any of their females are hardy enough to make this feaft, notwithftanding a hufband of the firft rank awaits as a fure reward the fuccefsful giver of it ; and the cuftom, I fince find, is peculiar to the Naudoweffies.

The Indians in their common fate are ftrangers to all diftinction of property, except in the articles of domeftick ufe, which every one confiders as his own, and increafes as circumftances admit. They are extremely liberal to each other, and fupply the deficiency of their friends with any fuperfluity of their own.

In dangers they readily give affiftance to thofe of their band who ftand in need of it, without any expectation of return, except of thofe juft rewards that are always conferred by the Indians on merit. Governed by the plain and equitable laws of nature, every one is rewarded folely according to his deferts; and their equality of condition, manners, and privileges, with that conftant and fociable familiarity which prevails throughout every Indian nation, animates them with a pure 


\section{(235)}

and truly patriotic fpirit, that tends to the general good of the fociety to which they belong.

If any of their neighbours are bereaved by death or by an enemy of their children, thofe who are poffeffed of the greateft number of naves, fupply the deficiency; and thefe are adopted by them and treated in every refpect as if they really were the children of the perfon to whom they are prefented.

The Indians, except thofe who live adjoining to the European colonies, can form to themfelves no idea of the value of money; they confider it when they are made acquainted with the ufes to which it is applied by other nations, as the fource of innumerable evils. To it they attribute all the mifchiefs that are prevalent among Europeans, fuch as treachery, plundering, devaftations, and murder.

They efteem it irrational that one man fhould be poffeffed of a greater quantity than another, and are amazed that any honour fhould be annexed to the poffeffion of it. But that the want of this ufelefs metal fhould be the caufe of depriving perfons of their liberty, and that on account of this partial diftribution 


\section{$(236)$}

diftribution of of it, great numbers fhould be immured within the dreary walls of a prifon, cut off from that fociety of which they conftitute a part, exceeds their belief. Nor do they fail, on hearing this part of the European fyftem of government related, to charge the inftitutors of it with a total want of humanity, and to brand them with the names of favages and brutes.

They thew almont an equal degree of indiffercnce for the productions of art. When any of there are thewn to them, they fay, "It is pretty, I like to look at it," but are not inquifitive about the conftruction of it, neither can they form proper conceptions of its ufe. But if you tell them of a perfon who is able to run with great agility, that is well fkilled in hunting, can direct with unerring aim a gun, or bend with eafe a bow, that can dexteroufly work a canoe, underftands the art of war, is acquainted with the fituation of a country, and can make his way without a guide, through an immenfe foreft, fubfitting during this on a fmall quantity of provifions, they are in raptures; they liften with great attention to the pleafing tale, and beftow the higheft comriendations on the hero of it.

$\mathrm{C} \mathrm{H} \Lambda \mathrm{P}$. 


\section{( 237 )}

$d$ be fon, C H A P. IV.

Their Metbod of reckoning. T I м E, Ecc.

CONSIDERING their ignorance of aftronomy, time is very rationally divided by the Indians. Thofe in the interior parts (and of thofe I would generally be underfood to (peak) count their years by winters; or, as they exprefs themfelves, by fnows.

Some nations among them reckon their years by moons, and make them confift of twelve fynodical or lunar months, obferving when thirty moons have waned, to add a fupernumerary one, which they term the loft moon; and then begin to count as before. They pay a great regard to the firft appearance of every moon, and on the occafion always repeat fome joyful founds, ftretching at the farine time their hands towards it.

Every Month has with them a name expreffive of its feafon ; for inftance, they call the month of March (in which their year generally begins at the firft New Moon after the vernal equinox) the Worm Month or Monn: 


\section{$(238)$}

Moon; becaufe at this time the worms quit their retreats in the bark of the trees, wood, \&c. where they have Meltered themfelves during the win:er.

The month of April is termed by them the Month of Plants. May, the Month of Flowers. June, the Hot Moon. July, the Buck Moon. Their reafon for thus denominating thefe is obvious.

Auguft, the Sturgeon Moon; becaufe in this month they catch great numbers of that filh.

September; the Corn Moon; becaufe in that month they gather in their Indian corn.

October, the Travelling Moon; as they leave at this time their villages, and travel towards the place where they intend to hunt during the winter.

November, the Beaver Moon; for in this month the beavers begin to take fhelter in their houfes, having laid up a fufficient ftore of provifions for the winter feafon.

December, the Hunting Moon, becaufe they employ this month in purfuit of their game.

January, the Cold Moon, as it generally freezes harder, and the cold is more intenfe in this than in any other month.

February 


\section{( 239 )}

February they call the Snow Moon, becaufe more fnow commonly falls during this month, than any other in the winter.

When the moon docs not thine they fay the moon is dead; and fome call the three laft days of it the naked days. The moon's firft appearance they term its coming to life again.

They make no divifion of weeks, but days they count by fleeps; half days by pointing to the fun at noon; and quarters by the rifing and fetting of the fun: to exprefs which in their traditions they make ufe of very fignificant hieroglyphicks.

The Indians are totally unfkilled in geography as well as all the other fciences, and yet as I have befure hinted, they draw on their birch-bark very exact charts or maps of the countries with which they are acquainted. The latitude and longitude is only wanting to make them tolerably complete.

Their fole knowledge in aftronomy confifts in being able to point out the pole-ftar; by which they regulate their courfe when they travel in the night.

They reckon the diftance of places, 'not by miles or leagues, but by a day's journey, which, 


\section{( 240$)$}

which, according to the beft calculations I could make, appears to be about twenty Fnglifh miles. Thefe they alfo divide into halves and quarters, and will demonftrate them in their maps with great exactners, by the hieroglyphicks juft mentioned, when they regulate in council their war parties, or their moft diftant hunting excurfions.

They have no idea of arithmetic; and though they are able to count to any number; figures as well as letters appear myfterious to them, and above their comprehenfion.

During my abode with the Naudoweffies, fome of the chiefs obferving one day a draft of an eclipfe of the moon, in a book of aftronomy which I held in my hand, they defired I would permit them to look at it. Happening to give them the book mut, they began to count the leaves till they came to the place in which the plate was. After they had viewed it, and afked many queftions relative to it, $I$ told them they needed not to have taken fo much pains to find the leaf on which it was drawn, for I could not only tell in an inftant the place, without counting the leaves, but alfo how many preceded it. 


\section{$(241)$}

They feemed greatly amazed at my affertion, and begged that $I$ would demonftrate to them the poffibility of doing it. To this purpofe I defired the chief that held the book, to open it in any particular place, and juft thowing. me the page, carefully to conceal the edges of the leaves, fo that I might not be able to count them.

This he did with the greateft caution; notwithftanding which, by looking at the folio, I told him to his great furprize the number of leaves. He counted them regularly over, and difcovered that I was exact. And when, after repeated trials, the Indians found I could do it with great readinefs, and without ever erring in my calculation, they all feemed as much aftonimed as if I had raifed the dead. The only way they could account for my knowledge, was by concluding that the book was a fpirit, and whifpered me anfwers to whatever I demanded of it.

This circumftance, trifling as it might appear to thofe who are lefs illiterate, contributed to increafe my confequence, and to augment the favourable opinion they already entertained of me. 


\section{$(242)$ \\ C $\mathrm{H}$ A P. V. \\ Of their GOVERNMENT, Eंc.}

H VERY feparate body of Indians is di1 vided into bands or tribes; which band or tribe forms a little community within the nation to which it belongs. As the nation has fome particular fymbol by which it is diftinguimed from others, fo each tribe has a badge from which it is denominated: as that of the Eagle, the Fanther, the Tiger, the Buffalo, \&c. \&c. One band of the Naudoweflie is reprefented by a Snake, another a Tortoife, a third a Squirrel, a fourth a Wolf, and a fifth a Buffalo. Throughout every nation they particularize themfelves in the fame manner, and the meaneft perfon among them will remember his lineal defcent, and diftinguilh himfolf by his refpective family.

Did not many circumftances tend to confute the fuppofition, I thould be almoft induced to conclude from this diftinction of tribes, and the particular attachment of the Indians to them, that they derive their origin as fome have afferted, from the Ifraelites.

Befides 
Befides this, every nation diftinguifh themfelves by the manner of conftruoting their tents or huts. And fo well verfed are all the Indians in this diftinction, that though there appears to be no difference on the niceft obfervation made by an European, yet they will immediately difcover, from the pofition of a pole left in the ground, what nation has encamped on the fpot many months before.

Every band has a chie? who is termed the Great Chief or the Chief Warrior; and who is chofen in confideration of his experience in war and of his approved valour, to dire? their military operations, and to regulate all concerns belonging to that department. But this chief is not confidered as the head of the ftate; befides the great warrior who is elected for his warlike qualifications, there is another who enjoys a pre-eminence as his hereditary right, and has the more immediate management of their civil affairs. This chief might with greater propricty be denominated the Sachem; whofe affent is neceffary in all conveyances and treaties, to which he affires the inark of the tribe or nution.

Though thefe two are confidered as the heads of the band, and the latter is ufually denominated their king, yet the Indians are 


\section{( 244$)$}

fenfible of neither civil or military fubordination. As every one of them entertains a high opinion of his confequence, and is extremely tenacious of his liberty, all injunctions that carry with them the appearance of a pofitive command, are inftantly rejected with fcorn.

On this account, it is feldom that their leaders are fo indifcreet as to give out any of their orders in a peremptory ftile; a bare hint from a chief that he thinks fuch a thing neceffary to be done, inftantly aroufes an emulation among the inferior ranks, and it is immediately executed with great alacrity. By this method the difgurful part of the command is evaded, and an authority that falls little fhort of abfolute fway inftituted in its room.

Among the Iadians no vifible form of government is eftablifhed; they allow of no fuch diftinction as migiftrate and fubject, every one appearing to enjoy an independence that cannot be controlled. The object of government among thein is rather foreign than domeftick, for their attention feems more to be employed in preferving fuch an union among the members of their tribe as will enable them to watch the motions of thcir enemies, and 


\section{(245)}

to aA againft them with concert and vigour, than to maintain interior order by any public regulations. If a fcheme that appears to be of fervice to the community is propofed by the chief, every one is at liberty to chufe whether he will affift in carrying it on; for they have no compulfory laws that lay thein under any reftrictions. If violence is committed, or blood is thed, the right of revenging thefe mifdemeanours are left to the family of the injured; the chicfs affume neither the power of inflicting or moderating the punifhment.

Some nations where the dignity is hereditary, limit the fucceffion to the female line. On the death of a chief, his fifter's fon fometimes fucceeds him in preference to his own fon; and if he happens to have no fifter, the neareft female relation affunes the dignity. This accounts for a woman being at the head of the Winnebagoe nation, which, befare I was acquainted with their laws, appeared Atrange to me.

Each family has a right to appoint one of its chiefs to be an affiftant to the principal chief, who watches over the intereft of his family, and without whofe confent nothing of a public nature can be carried into execution.

Thefe 


\section{( 246$)$}

Thefe are generally chofen for their ability in fpeaking; and fuch only are permitted to make orations in their councils and general affemblies.

In this body, with the hereditary chief at its head, the fupreme authority appears to be lodged; as by its deternination every tranfaction relative to their hunting, to their making war or peace, and to all their public concerns are regulated. Next to thefe, the body of warriors, which comprehends all that are able to bear arms, hold their rank, This divifion has fometimes at its head the chief of the nation, if he has fignalized himfelf by any renowned action, if not, fome chief that has rendered himfelf famous.

In their councils which are held by the foregoing members, every affair of confequence is debated; and no enterprize of the leaft moment undertaken, unlefs it there meets the general approbation of the chiefs. They commonly affemble in a hut or tent appropriated to this purpofe, and being feat. ed in a circle on the ground, the eldeft chief rifes and makes a fpeech; when he has concluded, another gets up; and thus they all fpeak, if neceffary, by turns. 


\section{( 247 )}

On this occafion their language is nervous, and their manner of expreffion emphatical. Their ftile is adorned with inages, comparifons, and ftrong metaphors, and is equal in allegories to that of any of the eaftern nations. In all their fet fpeeches they exprefs themfelves with much vehemence, but in common difcourfe, accorling to our ufual method of fpeech.

The young men are fuffered to be prefent at the councils, though they are not allowed to make a fpeech till they are regularly admitted : they however liften witn great attention, and to thew that they both underftand, and approve of the refolutions taken by the affembled chiefs, they frequently exclaim, "That is right." "That is good.".

The cuftomary mode among all the ranks. of expreffing their affent, and which they repeat at the end of almoit every period, is by uttering a kind of forcible afpiration, which founds like an union of the letters $\mathrm{OAH}$. 


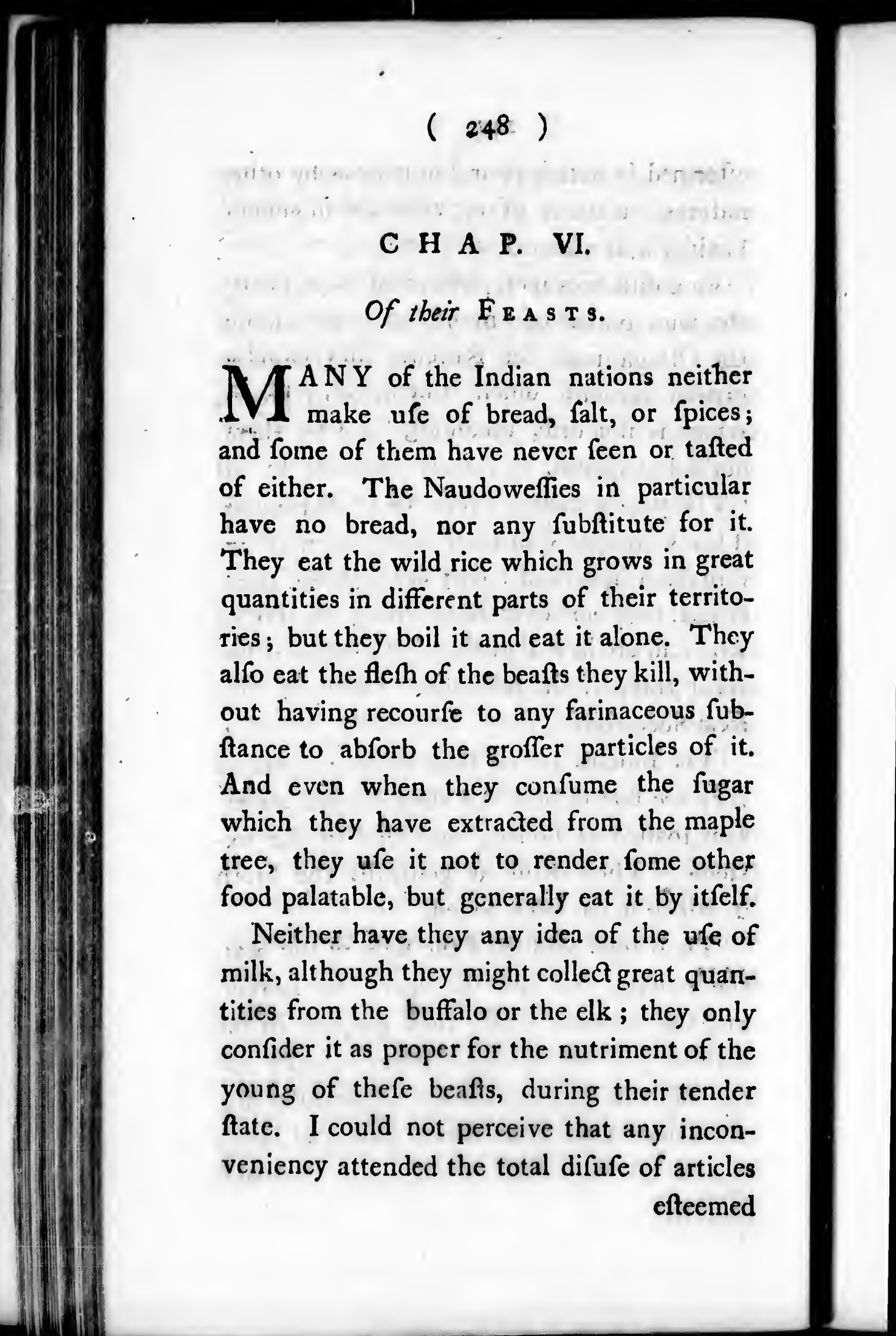




\section{( 249 )}

efteemed fo neceffary and nutritious by other nations, on the contrary, they are in general healthy and vigorous.

One difh however, which anfwers nearly the fame purpofe as bread, is in ufe among the Ottagaumies, the Saukies, and the more eaftern nations, where Indian corn grows, which is not only much efteemed by them, but it is ieckoned extremely palatable by all the Europeans who enter their dominions. This is compofed of their unripe corn as before defcribed, and beans in the fame ftate, boiled together with bears flefh, the fat of which moiftens the pulfe, and renders it beyond comparifon delicious. They call this food Succatolh.

The Indians are far from being canibals as they are faid to be. All their victuals are either roafted or boiled; and this in the extreme. Their drink is generally the broth in which it has been boiled.

Their food confifts of the flem of the bear, the buffalo, the elk, the deer, the beaver, and the racoon; which they prepare in the manner juft mentioned. They ufually eat the fleth of the deer which is naturally dry, with that of the bear which is fat and juicy; and 


\section{(250 )}

and though the latier is extremely rich and lufcious, it is never known to cloy.

In the fpring of the year, the Naudoweffies eat the infide bark of a fhrub, that they gather in forne part of their country; but I could neither learn the name of it, or difcover from whence they got it. It was of a brittle nature and eafily mafticated. The tafte of it was very agreeable, and they faid it was extremely nourifhing. In flavour it was not unlike the turnip, and when received into the mouth refembled that root both in its pulpous and frangible nature.

The lower ranks of the Indians are exceedingly nafty in drefling their victuals, but forne of the chiefs are very neat and cleanly: in their apparel, tents, and food.

They commonly eat in large parties, fo that their meals may properly be termed feafts: and this they do without being refiriced to any fixed or regular hours, but juft as their appetites require, and convenience fuits:

They ufually dance either before or after every meal: and by this cheerfulnefs, probably, render the Great Spirit, to whom they conlider themfelves as indebted for every good, a more acceptable facrifice than a for- 
mal and unanimated thankfgiving. The men and women feaft apart: and each fex invite by turns their companions to partake with them of the food they happen to have; but in their domeftic way of living the men and women eat together.

No people are more hofpitable, kind, and free than the Indians. They will readily fhare with any of their own tribe the laft part of their provifions, and even with thofe of a dificrent nation, if they chance to come in when they are eating. Though they do not keep one common ftock, yet that community of goods which is fo prevalent among them, and their generous difpofition, render it nearly of the fame effect.

When the chiefs are convened on any public bufinefs, they al ways conclude with a feaft, at which their fertivity and cheerfulnefs know. no limits.

\section{H A P. VII. \\ Of their DA N C ES.}

DANCING is a favourite exercife among the Indians; they never meet on any public occafion, but this makes a part 


\section{( 252$)$}

of the cntertainnient. And when they are not engaged in war or hunting, the youth of both fexes amufe themfelves in this manner every evening.

They always dance, as I have juft obferved, at their feafts. In thefe as well as all their other dances, every man rifes in his turn, and moves about with great freedom and boldncfs; finging, as he coes fo, the exploits of his anceftors. During this the company, who are feated on the ground in a circle, around the dancer, join with him in marking the cadence, by an odd tone, which they atter all together, and which founds "Heh, heh, heh." Thefe notes, if they might be fo termed, are articulated with a har:h accent, and ftrained out with the utmoft force of their lungs; fo that one would inagine their ftrength muft be foon exhaufted by it; inftead of which, they repeat it with the fame violcnce during the whole of their entertainment.

The women particularly thofe of the weftern nations, dance very gracefully. They carry themfilves erect, and with their arms hanging down clofe to their fides, , move firft a few yards to the right, and then back again to the left. This movement they perform 


\section{( 253$)$}

without taking any fteps as an European would do, but with their feet conjoined, moving by turns their toes and heels. In this manner they glide with great agility to a certain diftance, and then return; and let thofe who join in the dance be ever fo numerous, they keep time fo exactly with each other that no interruption enfues. During this, at ftated periods they mingle their forill voices with the hoarfer ones of the men who fit around (for it is to be obferved that the fexes never intermix in the fame dance) which, with the mufic of the drums and chichicoues, make an agreeable harmony.

The Indians have feveral kinds of dances which they ufe on different occafions, as the Pipe or Calumate Dance, the War Dance, the Marriage Dance, and the Dance of the Sacrifice. The movements in every one of thefe are diffimilar, but it is almoft impoffible to convey any idea of the points in which they are unlike.

Different nations likewife vary in their manner of dancing. The Chipéways throw themfelves into a greater variety of attitudes than any other people; fornetimes they hold their haads erect, at others they bend them almoft to the ground; then recline on one fide, 


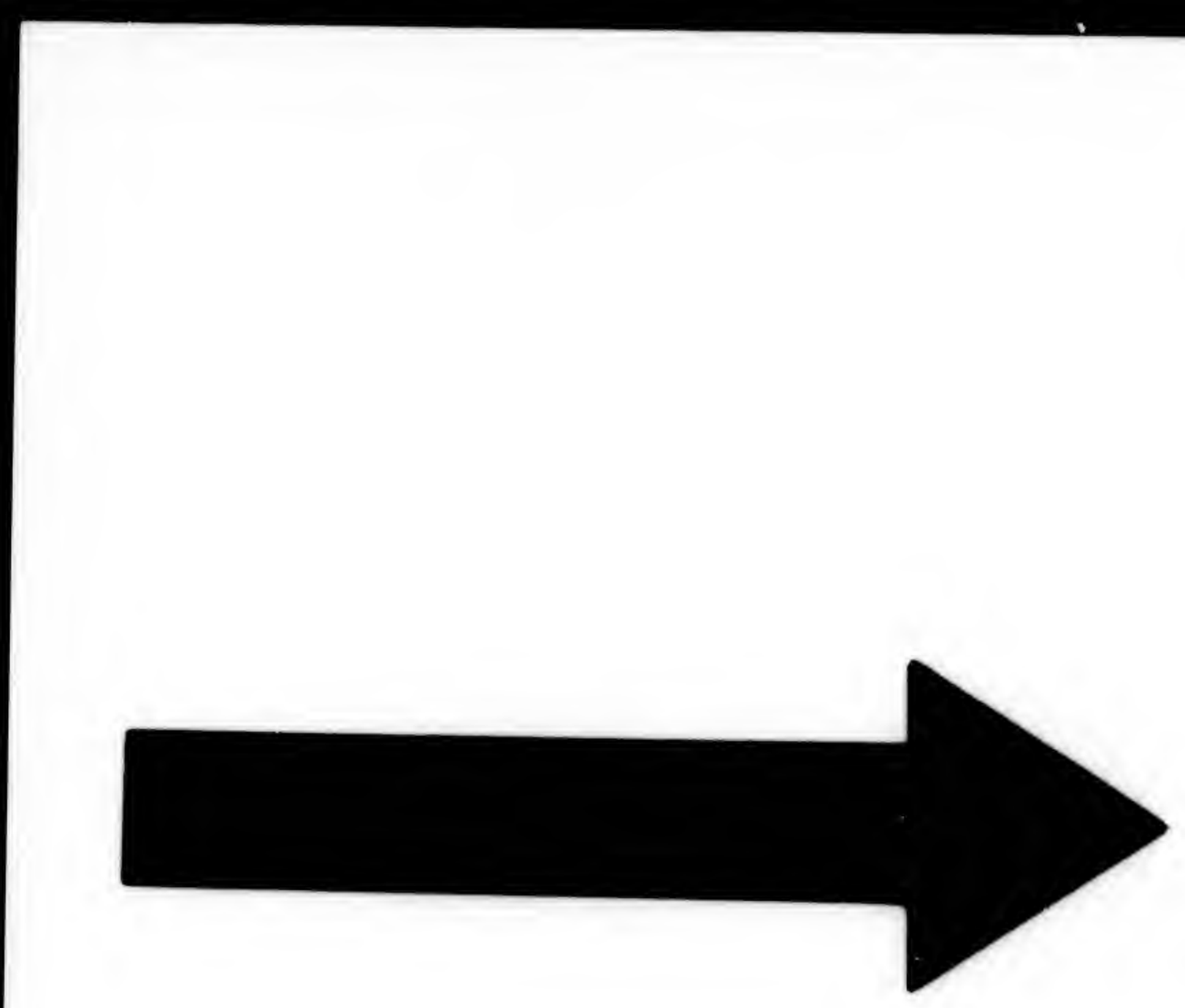




\section{IMAGE EVALUATION \\ TEST TARGET (MT-3)}
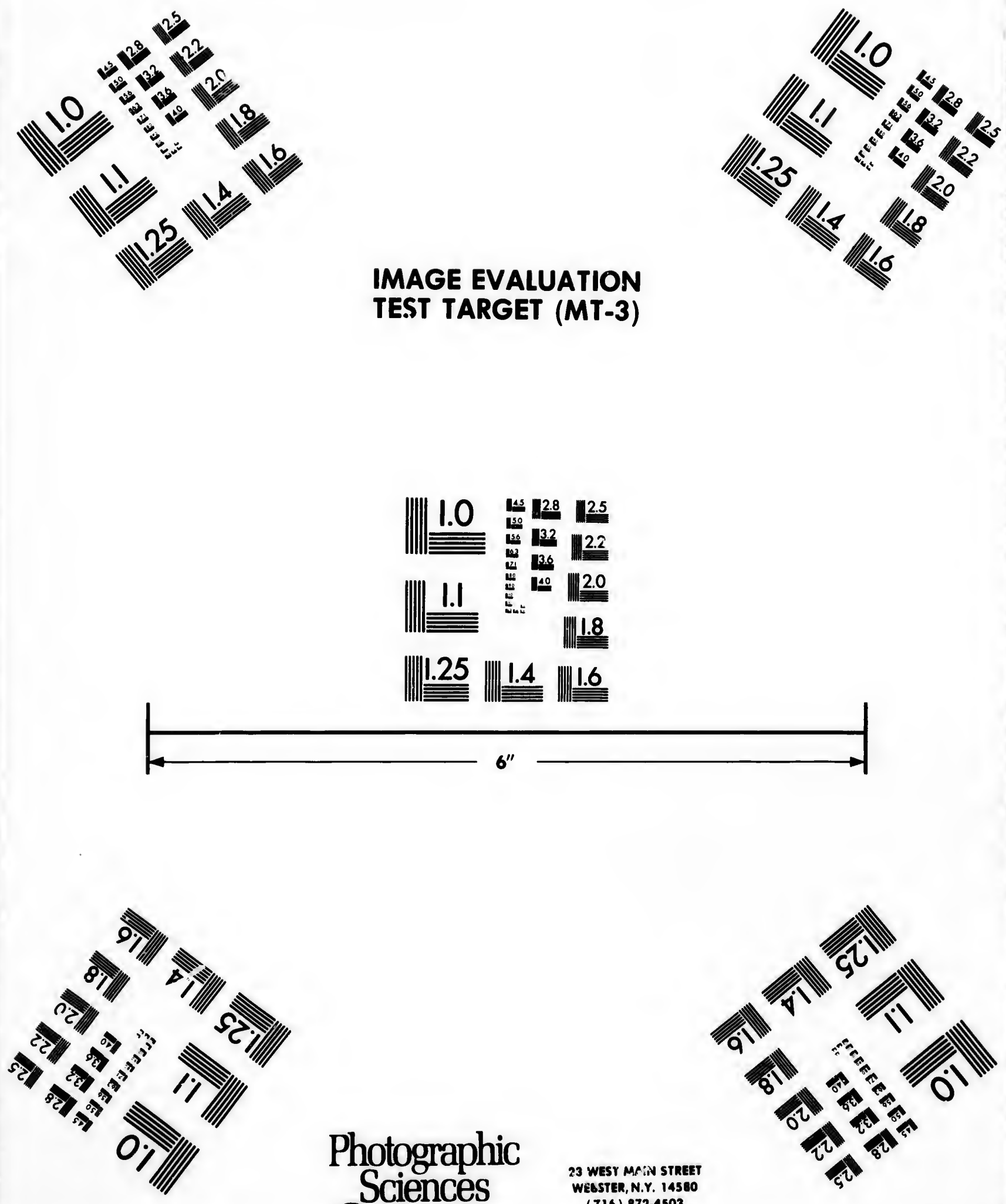

Photographic Sciences Corporation

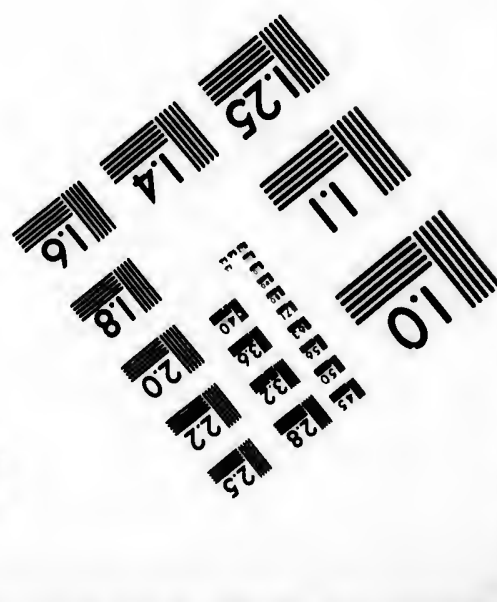





\section{(25t)}

fide, and immediately after on the other. The Naudowefles carry themfelves more upright, ftep firmer, and move more gracefully. But they all accompany their dances with the difagreeable noife juft mentioned.

The Pipe Dance is the principal, and the moft pleafing to the fpectators of any of them, being the leart frantic, and the movements of it the moft graceful. It is but on particular occafions that it is ufed; as when ambaffators from an enemy arrive to treat of peace, or when ftrangers of eminence pafs through their territories.

The War Dance, which they ufe both before they fet out on their war parties, and on their return from them, Atrikes terror into ftrangers. It is performed, as the others, amidft a circle of the warriors; a chief generally begins it, who moves from the right to the left, finging at the fame time woth his own exploits, and thofe of his ancefiors. When he has concluded his account of any memorable action, he gives a violent blow with his war-club againft a pont that is fixed in the ground, near the centre of the affembly for this purpofe.

Every one dances in his turn, and recapitulates the wondrous deeds of his family, till 


\section{$(.255)$}

ther.

they all at laft join in the dance. Then it becomes truly alarming to any fronger that happens to be among them, as they throw themfelves into every horrible and terrilying pofture that can be imagined, rehearfing at the fame time the parts they expect to at againft their enemies in the ficld. During this they hold their fharp knives in their hands, with which, as they whirl about, they are every moment in danger of cutting each others throats; and did they not thun the threatened mifchief with inconceivable dexterity, it could not be avoided. By there motions they intend to reprefent the manner in which they kill, fcalp, ard take their prifoners. To heighten the fcene, they fet up the fame hideous yells, cries, and war-hoops they ufe in time of ation: fo that it is impoffible to confider them in any other light than as an affembly of deinons.

I have frequently joined in this dance with them, but it foon ceafed to be an amufement to me, as I could not lay afide my apprehenfions of receiving fome dreadful wound, that from the violence of their geftures muft have proved mortal.

I found that the nations to the wertward of the Minfirippi, and on the borders of Laire

Superior,

hey 


\section{$(256)$}

Superior, ftill continue to make ufe of the Pawwaw or Black Dance. The people of the colonies tell a thoufand ridiculous ftories of the devil being raifed in this dance by the Indians. But they allow that this was in former times, and is now nearly extinct among thofe who live adjacent to the European fettlements. However I difcovered that it was ftill ufed in the interior parts; and though I did not actually fee the devil raifed by it, I was witnefs to fome fcenes that could only be performed by fuch as dealt with him, or were very expert and dexterous jugglers.

Whilft I was among the Naudoweffies, a dance, which they thus termed, was performed. Before the dance began, one of the Indians was admitted into a fociety which they denominated Wakon-Kitchewah, that is, the Friendly Society of the Spirit. This fociety is compofed of perfons of both fexes, but fuch only can be admitted into it as are of unexceptionable character, and who receive the approbation of the whole body. To this admiffion fucceeded the Pawwaw dance (in which I faw nothing that could give rife to the reports I had heard) and the whole, according 
according to their ufual cuftom concluded with a grand feaft.

The initiation being attended with fonte very fingular circumftances, which, as I have before obferved, muft be either the elfect of magick, or of amazing dexterity, 1 thall give a particular account of the whole procedure. It was performed at the time of the new moon, in a place appropriated to the purpofe near the centre of their camp, that would contain about two hundred people. Being a ftrazger, and on all occafions treated by them with great civility, I was invited to fee the ceremony, and placed clofe to the rails of the inclofure.

About twelve o'clock they began to affemble; when the fun thone bright, which they confidered as a good omen, for they never by choice hold any of their public meetings unilers the fky be clear and unclouded. A great number of chiefs firt appeared, who were dreffed in their beft apparel; and after them came the head-warrior, clad in a long robe of rich furs that trailed to the ground, attended by a retinue of fifteen or twenty perfons, painted and dreffed in the gayeft manner. Next followed the wives of fuch as had bcen already ad- 


\section{$\left(25^{8}\right)$}

mitted into the fociety; and in the rear a confufed heap of the lower ranks, all contributing as much as lay in their power to make the appearance grand and howy.

When the affembly was feated, and filence proclaimed, one of the principal chicfs arofe, and in a thort but mafterly fpeech informed his audience of the occafion of their meeting. He acquainted them that one of their young men wirhed to be admitted into their fociety; and taking him by the hand prefented him to their view, anking them, at the fame time, whether they had any objection to his becoming one of their community.

No objection being made, the young candidate was placed in the centre, and four of the chiefs took their ftations clofe to him; after exhorting him, by turns, not to faint under the operation he was about to go through, but to behave like an Indian and a man, two of them took hold of his arms, and caufed him to kneel; another placed himfelf behind him fo as to receive him when he fell, and the laft of the four retired to the diftance of about twelve feet trom him exactly in front.

This. 


\section{(259)}

r a

tri-

to

ince

ofe,

in-

heir

e of

into

hand

$\mathrm{n}$, at

ob-

com-

can-

ar of him; faint

p go and a arms, laced him refeet

This

This difpofition being completed, the chief that ftood before the kneeling candidate began to fpeak to him with an audible voice. He told him that he himfelf was now agitated by the fame fpirit which he hould in a few moments communicate to him; that it would frike him dead, but that he would inftantly be reftored again to lifis; to this he added, that the communication, however terrifying, was a neceffary introduction to the advantages enjoyed by the community into which he was on the point of being admitted.

As he fpoke this, he appeared to be greatly agitated; till at laft his emotions became fo violent, that his countenance was diftorted, and his whole frame convulfed. At this juncture he threw fomething that appeared both in thape and colour like ? fmall bean, at the young man, which feemed to enter his mouth, and he inftantly fell as motionlefs as if he had been thot. The chief that was placed behind him received him in his arms, and, by the affiftance of the other two, laid him on the ground to all appearance bereft of life.

Having done this, they immediately began to rub his limbs, and to frike him on the

back, 


\section{$260)$}

back, giving him fuch blows, as feemed more calculated to ftill the quick, than to raife the dead. During thefe extraordinary applica-

' tions, the fpeaker continued his harangue, defiring the fpectators not to be furprized, or to defpair of the young man's recovery, as his prefent inanimate fituation proceeded only from the forcible operation of the fpirit, on faculties that had hitherto been unufed to infpirations of this kind.

The candidate lay feveral minutes without fenfe or motion; but at length, after receiving many violent blows, he began to difcover fymptoms of returning life. Thefe, however, were attended with ftrong convulfions, and an apparent obftuction in his throat. but they were foon at an end; for having difcharged from his mouth the bean, or whatever it was that the chief had thrown at him, $\mathrm{t}$; which on the clofent infpection 1 had not perceived to enter it, he foon after appeared to be tolerably recovered.

This part of the ceremony being happily effected, the officiating chiefs difrobed him of the cloaths he had ufually worn, and put on him a fet of apparel entirely new. When he was dreffed, the fpeaker once mare took him by the hand, and prefented him to the fociety 


\section{( 261$)$}

fociety as a regular and thoroughly initiated member, exhorting them, at the fame time, to give him fuch neceffary affiftance, as being a young member, he might ftand in need of. He then alfo charged the newly elected brother to receive with humility, and to follow with punctuality the advice of his elder brethren.

All thofe who had been admitted within the rails, now formed a circle around this new brother, and the mufic friking up, the great chief fung a fong, celebrating as ufual their martial exploits.

The only mufic they make ufe of is a drum, which is compofed of a piece of a hollow tree curiounly wrought, and over one end of which is ftrained a $\mathrm{fkin}$, this they beat with a fingle ftick, and it gives a found that is far from harmonious, but it juft ferves to beat time with. To this they fometimes add the chichicoe, and in their war dances they likewife ufe a kind of fife, formed of a reed, which makes a thrill harfh noife.

The whole affembly were by this time united, and the dance began; feveral fingers affifted the mufic with their voices, and the women joining in the chorus at certain intervals, they produced together a not unpleafing 


\section{$(262)$}

pleafing but favage harmony. This was one of the moft agreeable entertainments I faw whilft I was among them.

I could not help laughing at a fingular childifh cuftom $I$ obferved they introduced into this dance, and which was the only one that had the laf appearance of conjuration. Molt of the members carried in their hands an otter or martin's $\mathrm{fkin}$, which being taken whole from the body, and filled with wind, on being compreffed, made a fqueaking noife through a fmall piece of wood organically formed and fixed in its mouth. When this inftrument was prefented to the face of any of the company, and the found emitted, the ifon receiving it inftantly fell down to appearance dead. Sometimes two or three, both men and women, were on the ground together; but immediately recovering, they rofe up and joined again in the dance, This feemed to afford, even the chiefs themfelves, infinite diverfion, I afterwards learned that thefe were thir Dil Penates or Hounhold Gods.

After fome hours fpent in this manner the feaft began; the difhes being brought near me, I perceived that they confifted of dog's Alerh; and I was informed that at all their public 


\section{$(263)$}

public grand feafts they never made ufe of any other kind of food. For this purpofe, at the feaft I am now speaking of, the new candidate provides fat dogs, if they can be procured at any price.

In this cuftom of eating dog's flefh on particular occafions, they refemble the inhabitants of fome of the countries that lie on the north-eaft borders of Afia. The author of the account of Kamfchatka, publifhed by order of the Emprefs of Ruffia (before referred to) informs us, that the people inhabiting Koreka; a country north of Kamfchatka; who wander about in hords like the Arabs, when they pay their worfhip to the evil beings, kill a rein-deer or a dog, the flem of which they eat, and leave the head and tongue fticking on a pole with the front towards the eaft. Alfo that when they are afraid of any infectious diftemper, they kill a dog, and winding the guts about two poles, pafs between them. There cuftoms, in which they are nearly imitated by the Indians, feem to add Atrength to my fuppofition, that America was firt peopled from this quarter.

- 1 know not under what clafs of dances to rank that performed by the Indians who came to my tent when I landed near Lake Pepin, 


\section{(264)}

on the banks of the Miffiffippi, as related in my Journals. When I looked out, as I there mentioned, I faw about twenty naked young Indians, the moft perfect in their fhape, and by far the handfomeft of any I had ever feen, coming towards me, and dancing as they approached, to the mufic of their drums. At every ten or twelve yards they halted, and fet up their yells and cries.

When they reached my tent, I anked them to come in; which without deigning to make me any anfwer, they did. As I obferved that they were painted red and black, as they ulually are when they go againft an enemy, and perceived that fome parts of the wardance were intermixed with their other movements, I cloubted not but they were fet on by the inimical chief who had refufed my falutation: I therefore determined to fell $\mathrm{my}$ life as dear as paffible. To this purpore, I received them fitting on my cheft, with my gun and piftols befide mé, and ordered my men to keep a watchful eye on them, and to be alfo upon their guard.

The Indians being entered, they continued their dance alternately, finging at the fame timse of their heroic exploits, and the fuperiority of their race over every other peo- 


\section{$(265)$}

ple. To enforce their language, though it was uncommonly nervous and expreffive, and fuch as would of itfelf have carried terror to the firmeft heart, at the end of every period they ftruck their war-clubs againt the poles of my tent, with fuch violence, that $i$ expected every moment it would have tumbled upon us.' As each of them, in dancing round, paffed by me, they placed their right hands over their eyes, and coming clofe to me, looked ine feadily in the face, which I could not conftrue into a token of friendihip. My men gave themfelves up for loft, and I acknowledge for my own part, that I never found my apprehenfions more tumultuous on any occafion.

When they had nearly ended their dance, I prefented to them the pipe of peace, but they would not receive it. I then, as my laft refource, thought I would try what prefents would do; accordingly I took from my cheft fume ribands and trinkets, which I laid before then. Thefe feemed to ftagger their refolutions, and to avert in fome degree their anger; for after holding a confultation together, they fat down on the ground, which I confidered as a favourable omen. 


\section{$(266)$}

Thus it proved, as in' a fhort time they received the pipe of peace, and lighting it, firt prefented it to me, and then fmoakel with it themfelves. Soon after they took up the prefents, which had hitherto lain neglected, and appearing to be greatly pleafed with them, departed in a friendly manner. And never did I receive greater pleafure than at getting rid of fuch formidable guefts.

It was not ever in my power to gain a tho. rough knowledge of the defigns of my vifiters. I had fufficient reafon to conclude that they were hoftile, and that their vifit, at folate an hour, was made through the inftigation of the Grand Sautor; but I was afterwards informed that it might be intended as a compliment which they ufually pay to the chiefs of every other nation who happen to fall in with them, and that the circumftances in their conduet which had appeared fo fufpicious to me, were merely the effects of their vanity, and defigned to imprefs on the minds of thofe whom they thus vifited an elevated opinion of their valour and prowefs. In the morning before I continued my route, feveral of their wives brought me a prefent of fome fugar, for whom I found a few more ribands. 
The Dance of the facrifice is not fo denominated from their offering up at the fame time a facrifice to any good or evil fpirit, but is a dance to which the Naudoweflies give that title from being ufed when any public fortunate circumftance befalls them. Whilft I refided among them, a fine large deer accidentally ftrayed into the middle of their encampment, which they foon deftroycd. As this happened juft at the new moon, they efteemed it a lucky omen; and having roafted it whole, every one in the camp partook of it. After their feaft, they all joined in a dance, which they termed from its being fomewhat of a religicus nature, a Dance of the facrifice.

\section{C $\quad$ H A P. VIII. \\ Of their $\mathrm{HUN}$ U ING.}

heir inds ated the eve:$t$ of hore

HUNING is the principal occupation 11 of the Indians; they are trained to it from their earlieft youth, and it is an exercife which is efteemed no lefs honourable than receffary towards their fubfiftence. A dextrous and refolute hunter is held nearly 


\section{( 268$)$}

in as great eftimation by them as a diftinguifhed warrior. Scarcely any device which the ingenuity of man has difcovered for enfnaring or deftroying thofe animals that fupply them with food, or whofe fkins are valuable to Europeans, is unknown to them.

Whilft they are engaged in this exercife; they fhake off the indolence peculiar to their nature, and become active, perfevering, and indefatigable. They are equally fagacious in finding their prey, and in the means they ufe to deftroy it. They difcern the footfteps of the beafts they are in purfuit of, although they are imperceptible to every other eye, and can follow them with certainty through the pathlefs foreft.

The beafts that the Indians hunt, both for their flefh on which they fubfif, and for their fkins, of which they either make their apparel, or barter with the Europeans for neceffaries, are the buffalo, the elk, the deer, the moofe, the caraboe, the bear, the beaver, the otter, the martin, \&c. I thall defer giving a defcription of thefe creatures, and thall only at prefent treat of their manner of hunting them.

The route they thall take for this purpore, and the parties that mall go on the different 


\section{( 269)}

expeditions are fixed in their general councils which are held fome time in the fummer, when all the operations for the enfuing winter are concluded on. The chief-warrior, whofe province it is to regulate their proceedings on this occafion, with great folemnity iffues out an invitation to thofe who chufe to attend him; for the Indians, as before obferved, acknowledge no fuperiority, nor have they any idea of compulfion; and every one that accepts it prepares himfelf by fafting during feveral days.

The Indians do not faft as fome other nations do; on the richeft and moft luxurious food, but they totally abftain from every kind either of victuals or drink; and fuch is their patience and refolution, that the mort extreme thirf could not oblige them to tafte a drop of water; yet amicilt this fevere abftinence they appear cheerful and happy:

The reafon they give for thus fafting, are, that it enables them freely to dream, in which dreams they are informed where they thall find the greateft plenty of game; and alfo that it averts the difpleafure of the evil fpirits, and induces them to be propitious. They alfo on thefe occafions blacken thofe parts of their bodies that are uncovered.

The 


\section{$\int 1 \sqrt{1}(270)$}

The faft being ended, and the place of hunting made known, the chief who is to conduat them, gives a grand feaft to thofe who are to form the different parties; of which none of them dare to partake till they have bathed themfelves. At this feaft, notwithftanding they have fafted fo long, they eat with great moderation; and the chief that prefides employs himfelf in rehearfing the feats of thofe who have been moft fuccefsful in the bufinefs they are about to enter upon. They foon after fet out on the march towards the place appointed, painted or rather bedaubed with black, amidft the acclamations of all the people.

It is impoffible to dcfcribe their agility or perfeverance, whillt they are in purfuit of their prey; neither thickets, ditches, torrents, poo's, or rivers ftop ihem; they always go frait forward in the moft direct line they poffibly can, and there are few of the favage inhabitants of the woods that they cannot overtake.

When they hunt for bears, they endeavour to find out their retreats; for, during the winter, thefe animals conceal themfelves in the hollow trunks of trees, or make themfelves holes in the ground, where they con- 


\section{$(271)$}

tinue without food, whilft the fevere weather lafts.

When the Indians think they have arrived at a place where thefe creatures ufually: haunt, they form themfelves into a circle according to their number, and moving onward, endeavour, as they advance towards the centre, to difcover the retreats of their prey. By this means, if any lie in the intermediate fpace, they are fure of roufing them, and bringing them down either with their bows or their guns, The bears will take to flight at fight of a man or a dog, and will only make refiftance when they are extremely hungry, or after they are wounded.

The Indian method of hunting the buffalo is by forming a circle or a fquare, nearly in the fame manner as when they fearch for the bear. Having taken their different ftations, they fet the grafs, which at this time is rank and dry, on fire, and thefe animals, who are extremely fearful of that element, flying with precipitation before it, great numbers are hemmed in a fmall compafs, and fcarcely a fingle one efcapes.

They have different ways of hunting the elk, the deer, and the caraboe. Sometimes they feek them out in the woods, to which 


\section{( 272$)$}

they retire during the feverity of the cold, where they are eafily thot from behind the trees. In the more northern climates they take the advantage of the weather to deftroy the elk; when the fun has juft ftrength enough to melt the fnow, and the froft in the night forms a kind of cruft on the furface, this creature being heavy, breaks it with his forked hoofs, and with difficulty extricates himfelf from it; at this time therefore he is foon overtaken and deftroyed.

Some nations have a method of hunting thefe animals, which is more eafily executed; and free from danger. The hunting party' divide themfelves into two bands, and choofing a fpot near the borders of foine river, one party embarks on board their canoes, whilft the other forming themfelves into a feni-circle on the land, the flanks of which reach the thore, let loofe their dogs, and by this means roufe all the game that lies within thefe bounds; they then drive them to'vards the river, into which they no fooner enter; than the greateft part of them are immediately difpatched by thofe who remain in the canoes.

Both the elk and the buffalo are very furious when they are wounded, and will re- 
turn fiercely on their purfuers, and trample them under their feet, if the hunter finds not : means to complete their deftruction, or feeks for fecurity in flight to fome adjacent tree; by this method they are frequently a zoided, and fo tired with the purfuit, that they voluntarily give it over.

But the hunting in which the Indians, particularly thofe who inhabit the northern parts, chiefly employ themfelves, and from which they reap the greateft advantage, is the beaver hunting. The feafon for this is throughout the whole of the winter, from November to April; during which time the fur of thefe creatures is in the greateft perfection. A defcription of this extraordinary animal, the conftruction of their huts, and the regulations of their almoft rational community, I fhall give in another place.

The hunters make ufe of feveral methods to deftroy them. Thofe generally practifed, are either that of taking them in fnares, cutting through the ice, or opening their caufeways.

As the eyes of thefe animals are very quick, and their hearing exceedingly acute, great precaution is neceffary in approaching their abodes; for as they feldom go far from the 


\section{( 274$)$}

water, and their houfes are always built clofe to the fide of fome large river or lake, or dams of their own conftructing, upon the leaft alarm they haften to the deepeft part of the water, and dive inmediately to the bottom; as they do this they make a great noife by beating the water with their tails, on purpofe to put the whole fraternity on their guard:

They take them with fnares in the following manner: though the beavers ufually lay up a fufficient ftore of provifions to ferve for their fubfiftence during the winter, they make from time to time excurfions to the neighbouring woods to procure further fupplies of food. The hunters having found out their haunts, place a trap in their way, baited with fmall pieces of bark, or young fhoots of trees, which the beaver has no fooner laid hold of: than a large log of wood falls upon him, and breaks his back; his enemies; who are upon the watch, foon appear, and inftantly difpatch the helplefs animal.

At other times, when the ice on the rivers and lakes is about half a foot thick; they. nake an opening through it with their hatchets, to which the beavers will foon haften, on being difturbed at their houfes, for

a fupply 


\section{( 275$)$}

a fupply of frefh air. As their breath occafrons a confiderable motion in the water, thic hunter has fufficient notice of their approách, and methods are eafily taken for knocking them on the head the moment they appear above the furface.

When the houfes of the beavers happen to be near a rivulet; they are more eafily deftroyed: the hunters then cut the ice, and fpreading a net under it, beak down the cabins of the beavers, who never fail to make towards the decpeft part, where they are entangled and taken. But they mult nut be fuffered to remain there long, as they would foon extricate themfelves with their teeth, which are well known to be excefively floarp and ftrong.

The Indians take great care to hiuder their dogs from touching the bones of the beavers. The reafons they give for thefe precautions are, firft, that the bones are fo exceffively hard, that they fpoil the teeth of the digs; and, fecondly, that they are apprehenfive they fhall fo exafperate the fpirits of the beaversiby this permiffion, as to render the next hunting feafon unfuccefsful.

The Rins of thefe animals the liunters exchange with the Europeans for neceffaries; $\mathrm{T}_{2}$ and 


\section{$\left({ }_{276}\right)$}

and as they are more valued by the lattes than any other kind of furs, they pay the greateft attention to this fpecies of hunting.

When the Indians deftroy buffalos, elks, deer, \&c. they generally divide the flem of fuch as they have taken, among the tribe to which they belong. But in hunting the beaver a few families ufually unite and divide the fpoil between them. Indeed, in the firf inftance, they generally pay fome attention in the divifion to their own families; but no jealoufies or murmurings are ever known to arife on account of any apparent partiality.

Among the Naudoweffies, if a perfon Thoots a deer, buffalo, \&c. and it runs to a confiderable diftance before it drops, where a perfon belonging to another tribe, being nearer, firft fticks a knife into it, the game is confidered as the property of the latter, notwithftanding it had been mortally wounded by the former. Though this cuftom appears to be arbitrary and unjuft, yet that people cheerfully fubmit to it. This decifion is, however, very different from that practifed by the Indians on the back of the colonies, where the firft perfon that hits it is entitled to the beft thare.

C. H A P. 
Of their Manner of making $\mathrm{W}_{\mathrm{A} \mathrm{R}}, \mathrm{E}^{\circ} \mathrm{c}$.

$\mathrm{HE}$ Indians begin to bear arms at the
age of fifteen, and lay them afide when they arrive at the age of fixty. Some nations to the fouthward, I have been informed, do not continue their nilitary exercifes after they are fifty.

In every band or nation there is a felect number who are ftiled the Warriors, and who are always ready to act either offenfively or defenfively, as occafion requires. Thefe are well armed, bearing the weapons commonly in ufe among them, which vary according to the fituation of their countries. Such as have an intercourfe with the Europeans make ufe of tomahawks, knives, and - fire-arms; but thofe whofe dwellings are fituated to the weftward of the Miffiflippi, and who have not an opportunity of purchafing there kinds of weapons, ufe bows and arrows, and alfo the Caffé Tête or war club. 


\section{$(278)$}

The Indians that inhabit fill farther to the weftward, a country which extends to the South Sea, ufe in fight a warlike inftrument that is very uncommon. Having great plenty of horfes, they always attack their cnemies on horfeback, and encumber themfelves with no other weapon, than a ftone of a middling fize; curioully wrought, which they faften by a ftring, about a yard and half long, to their right arms, a little above the elbow. Thefe fones they conveniently carry in their hands till they reach their enemies, and then fwinging them with great dexterity, as they ride full rpeed, never fail of doing execution, The country which thefe tribes poffefs, abounding with large extenfive plains, thore who attack them feldom return; as the fwiftnefs of the horfes on which they are mounted, enables them to overtake even the fleet. eft of their invaders.

The Naudoweffies, who had been at war. with this people, informed me, that unler's they found moraffes or thickets to which they could retire, they were fure of being cut off: to prevent this they, always took care whenever they made an onfet, to do it near fuch: retreats as were impaffable for cavalry, they then having a great advantage over their ene-

mies, 



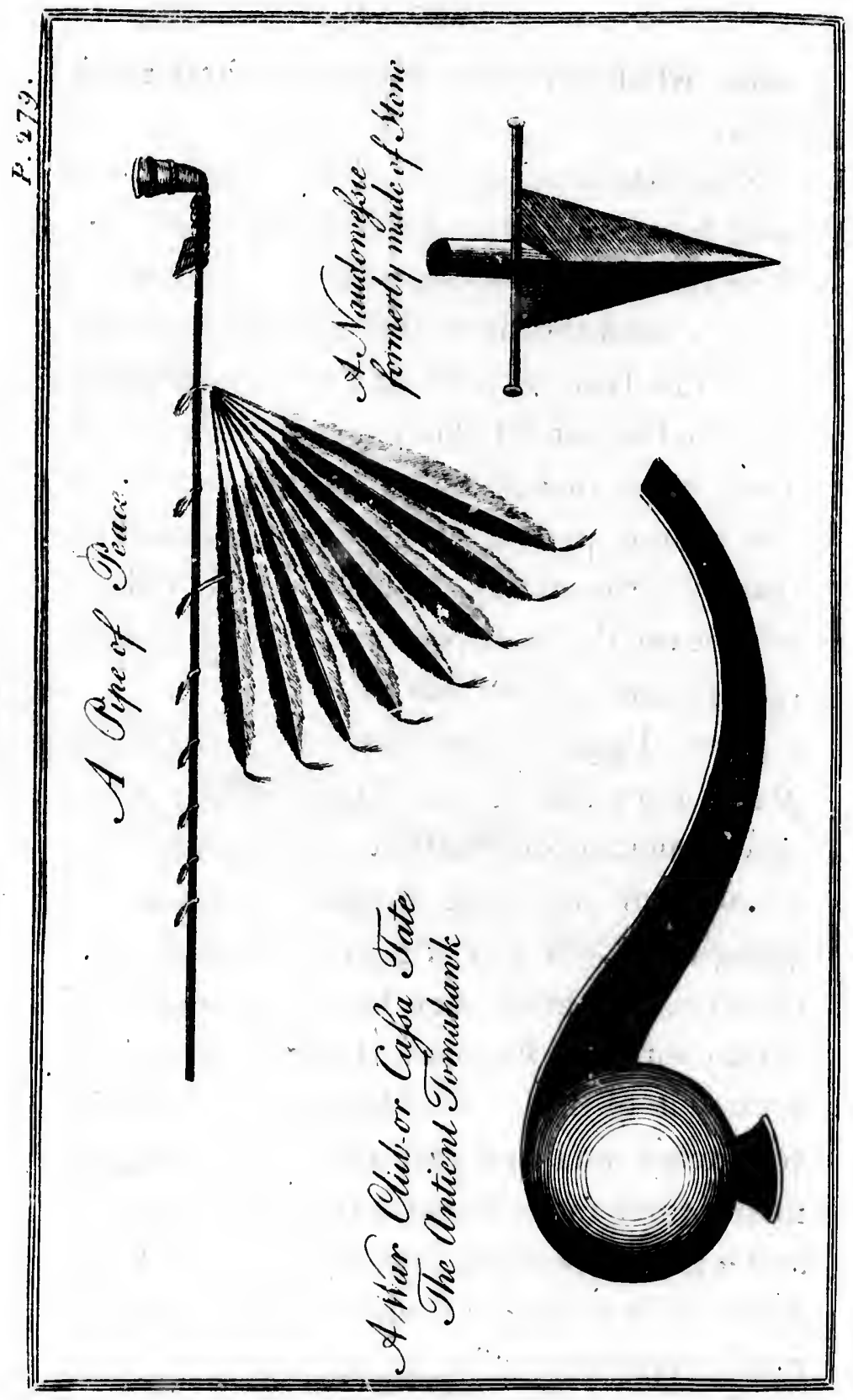




\section{( 279 )}

mies, whofe weapons would not there reach thom.

Some nations make ufe of a javelin pointed with bone worked into different forms; but their Indian weapons in general ale bows and arrows, and the thort club already mentioned. The latter is made of a very hard wood, and the head of it fahioned round like a ball, about three inches and a half diameter; in this rotund part is fixed an edge relembling that of a tomahawk, either of ftoel or flint, whichever they can procure; fmilar to that reprefented in Plate No. IV.

The dagger placed near it in the fame plate, is peculiar to the Naudoweffie nation, and of ancient conftruction, but they can give no accoult how long it has been in ufe among them. It was originally made of flint or bone, but fince they have had communication with the European traders, they have formed it of fteel. The length of it is about ten inches, and that part clore to the hat dle noarly three inches broad. Its edges are keen, and it gradually tapers towards a point: They wear it in a theath made of deer's leather; neatly ornamented with porcupines quills; and it is ufually hung by a ftring, decorated is the fame manner, which reackes as low only 


\section{( 280$)$}

only as the breaft. This curious weapon is worn by a few of the principal chiefs alone; and confidered both as a ufeful inftrument, and an ornamental badge of fupetiority.

I obferved among the Naudoweffies a few targets or fhields made of raw buffalo hides, and in the form of thofe ufed by the ancients. But as the number of thefe was fmall; and I could gain no intelligence of the ara in which they firf were introduced among them, I fuppofe thofe I faw had defcended from father to fon for many generations.

The reafons the Indians give for making war againft one another, are much the fame as thofe urged by more civilized nations for difturbing the tranquillity of their neighbours. The pleas of the former are however in general more rational and juft, than fuch as are brought by Europeans in vindication of their proceedings.

The extenfion of empire is feldom a mor tive with thefe people to invade, and to comr mit depredations on the territories of thofe who happen to dwell near them. To fecure the rights of hunting within particular limits, to maintain the liberty of paffing through their accuftomed tracks, and to guard thofe lands which they contider from a long tenure 


\section{( 28r)}

as their own, againft any infringement, are the general caufes of thofe diffenfions that fo often break out between the Indian nations, and which are carried on with fo much animofity. Though ftrangers to the idea of feparate property, yet the moft uncultivated among them are well acquainted with the rights of theircommunity to the domains they poffefs, and oppofe with vigour every encroachment on them.

. Notwithftanding it is generally fuppofed that from their territories being fo extenfive, the boundaries of them cannot be afcertained, yet I am well affured that the limits of each nation in the interior parts are laid down in their rude plans with great precifion. By theirs, as I have before obferved, was I enabled to regulate my own; and after the moft exact obfervations and enquiries found very few inftances in which they erred.

- But intereft is not either the moft frequent or moft powerful incentive to their making war on each other. The paffion of revenge, which is the diftinguining characteriftic of thefe people, is the moft general motive. Injuries are felt by them with exquifite fenfibility, and vengeance purfued with unremitted ardour. To this may be added, that natural 


\section{( 282$)$}

excitation which every Indian becomes fenfible of as foon as he approaches the age of manhood, to give proofs of his valour and prowefs.

As they are early poffefled with a notion that war ought to be the chief bufinefs of their lives, that there is notling more definrous than the reputation of being a great warrior, and that the fcalps of their enemies or a number of prifoners are alone to be ef. teemed valuable, it is not to be wondered at that the younger Indians are continually reft. lefs and uneafy if their andour is repreifed, and they are kept in a fate of inactivity. Either of thefe propenfities, the defire of re. venge, or the gratification of an impulfe that by degrees becomes habitual to them, is fuf, ficient, frequently, to induce them to com mit hoftilities on fome of the neighbouring nations.

When the chiefs find any occalion for making war, they endeavour to aroufe thefe habitudes, and by that means foon excite their warriors to take arms. To this purpofe they. make ufe of their martial eloquenoe nearly in the following words, which never fails of proving effectual. "The bones of owr de. " ceafed countrymen lie uncovered, they calt. 


\section{( 283$)$}

"out to us to revenge their wrongs, and we " muft fatisfy their requeft. Their spirits "cry out againit us, they mult be appeafed. "The genii, who are the guardians of our " honour, infpire us with a refolution to feek " the enemies of our murdered brothers. Let " vs go and devour thofe by whom they were "Aain. Sit therefore no longer inactive, give "way to the impulfe of your natural valour, " anoint your hair, paint your faces, fill your 4 quivers, caufe the forefts to refound with "your fongs, confole the fpirits of the dead, "and tell them they nall be revenged."

Animated by thefe exhortations the warriors fnatch their arms in a iranfport of fury, fing the fong of war, and burn with impatience to imbrue their hands in the bluod of their enemies.

Sometimes private chiefs affemble finall parties, and make excurfions againft thofe with whom they are at war, or fuch as have injured them. A fingle warrior, prompted by revenge or a defire to thow his prowers, will march unattended for feveral hundred iniles, to furprize and cut off a ftraggling party.

Thefe irregular fallies, however, are not always approved of by the elder chiefs, though they are often obliged to connive at them; as 


\section{$\left(28_{4}\right)$}

in the inftance before given of the Naudoweffie and Chipéway nations.

But when a war is national, and undertaken by the community, their deliberations are formal and flow.' The elders affemble in council, to which all the head warriors and young men are admitted, where they deliver their opinions in folemn fpeeches, weighing with maturity the nature of the enterprize they are about to engage in, and balancing with great fagacity the advantages or inconveniencies that will arife from it.

Their priefts are alfo confulted on the fubject, and even, fometimes, the advice of the moft intelligent of their women is alked.

If the determination be for war, they prepare for it with much ceremony.

The chief warrior of a nation does not on all occafions head the war party himfelf, he frequently deputes a warrior of whofe valour and prudence he has a good opinion. The perfon thus fixed on being firft bedawbed with black, obferves a faft of feveral days, during which he invokes the Great Spirit; or deprecates the anger of the evil ones, holding whilf it lafts no converfe with any of his tribe. 


\section{$(285)$}

He is particularly careful at the fame time to obferve his dreams, for on thefe do they fuppofe their fuccefs will in a great meafure depend; and from the firm perfuaion, every Indian actuated by his own prefumptuous thoughts is impreffed with, that he mall march forth to certain vichory, thefe are generally favourable to his wilhes.

After he has fafted as long as cultom prefcribes, he affembles the warriors, and holding a belt of wampum in his hand thus addreffes them:

"Brothers! by the infpiration of the Great "Spirit I now fpeak unto you, and by him " am I prompted to carry into execution the " intentions which I am about to difclofe to "you. The blood of our deceafed brothers "is not yet wiped away; their bodies are " not yet covered, and I am going to perform " this duty to them."

Having then made known to them all the motives that induce him to take up arms againft the nation with whom they are to engage, he thus proceeds: "I have therefore "refolved to march through the war-path " to furprize them. We will eat their flefh " and drink their blood; we will take fcalps, " and malse prifoners; and hould we perifh 


\section{$(286)$}

* in this glorious enterprize, we thall not be "for ever hid in the duft, for this belt thall "be a recompence to hin who buries the " dead." Having faid this, he lays the belt on the ground, and he who takes it up declares himfelf his lieutenant, andi is confidered as the fecond in command; this, however, is only done by fome diftinguifhed warrior who has a right, by the number of his fealps, to the poit.

Though the Indians thus affert that they will eat the fiem and drink the blood of their enemies, the threat is only to be confidered as a figurative expreffion. Notwithftanding they fometimes devour the hearts of thofe they nlay, and drink their blood, by way of bravado, or to gratify in a more complete manner their revenge, yet they are not naturally anthropophagi, nor ever feed on the flem of men.

The chief is now wafhed from his fable covering, anointed with bears fat, and painted; with their red paint, in fuch fignres as will make him appear moft rerrible to his enemies. He then fings the war-fong, and enumerates his warlike actions. Heving done this he fixes his eyes on the fun, and pays his adorations

co

ch

to

di

ne

fit

ar

m:

th

pe

du

fe.

al

as

m

an

po

of

ha 


\section{( 297$)$}

adorations to the Great Spirit, in which he is accompanied by all the warriors.

This ceremony is followed with dances, fuch as I have before defcribed; and the whole concludes with a feaft which ufually confifts of dogs flefh.

This feaft is held in the hut or tent of the chief warrior, to which all thofe who intend to accompany him in his expedition fend their difhes to be filled; and during the feaft, notwithftanding he has fafted fo long, he fits compofedly with his pipe in his mouth, and recounts the valorous deeds of his family.

As the hopes of having their wounds, fhould they receive any, properly treated, and expeditiounly cured, muft be fome additional inducement to the warriors to expofe themfelves more freely to danger, the priefts, who alfo are their doctors, prepare fuch medicines. as will prove efficacious., With great ceremony they collect various roots and plants. and pretend that they impart to them the. power of healing.

Notwithftanding this fuperftitious method of proceeding; it is very certain that they have acquired a knowledge of many plants 


\section{( 288$)$}

and herbs that are of a medicinal quality, and which they know how to ufe with great Akill.

From the time the refolution of engaging in a war is taken, to the departure of the warriors, the nights are fpent in fefivity, and their days in making the needful preparations.

If it is thought neceffary by the nation going to war, to folicit the alliance of any neighbouring tribe, they fix upon one of their chiefs who fpeaks the language of that people well, and who is a good orator, and fend to them by him a belt of wampum, on which is fpecified the purport of the embaffy in figures that every nation is well acquainted with. At the fame time he carries with him a hatchet painted red.

As foon as he reaches the camp or village to which he is deftined, he acquaints the chief of the tribe with the general tenor of his commiffion, who immediately affembles a council, to which the ambaffador is invited. There having laid tho hatchet on the ground, he holds the belt in his hand, and enters more minutaly into the occafion of his embaffy. In his freech he invites them to take up the hatchet, and as foon as he has finilned fpeaking delivers the belt. 


\section{( 289 )}

If his hearers are inclined to become auxiliaries to his nation, a chicf fteps forward and takes up the hatchet, and they inmediately efpoufe with fpirit the caufe they have thus engaged to fupport. But if on this application neither the belt or hatchet are accepted, the emiffary concludes that the people whofe affiftance he folicits have already entered into an alliance with the foes of his nation, and returns with fpeed to inform his countrymen of his ill-fuccefs.

The manner in which the Indians declare war againft cach other, is by fending a flave with a hatchet, the handle of which is painted red, to the nation which they intend to break with; and the meffenger, notwithftanding the danger to which he is expofed from the fudden fury of thofe whom he thus fets at defiance, executes his commiffion with great fidelity.

Sometimes this tolsen of defiance has fuch an inftantaneous effect on thofe to whom it is prefented, that in the firft tranfport's of their fury a fmall party will iffue forth without waiting for the permiffion of the elder chiefs, and naying the firft of the offending nation they meet, cut open the body and ftick a hatchet of the fame kind as that they have 


\section{( 290$)$}

juft received, into the heart of their Aaughtered foe. Among the more remote tribes this is done with an arrow or fpear, the end of which is painted red. And the more to exafperate, they difmember the body, to how that they eftem them not as men but as old women.

The Indians feldom take the field in large bodies, as fuch numbers would require a greater degree of induftry to provide for their fubfiftence, during their tedious marches through dreary forefts, or long voyages over lakes and rivers, than they would care to beftow.

Their armies are never encumbered with baggage or military ftores. Each warrior, befides his weapons, carries with him only a mat, and whilft at a diftance from the frontiers of the enemy fupports himfelf with the game he kills or the fifh he catches.

When they pals through a country where they have no apprcheafions of meeting with an enemy, they ufe very little precaution: fometimes there are fcarcely a dozen warriors lett together, the reft being difperfed in purfuit of their game; but though they fhould have roved to a very confiderable diftance from the war-path, they are fure to arrive at 


\section{( $29 i)$}

the place of rendezvous by the hour appointed.

They always pitch their tents long before fun-fet; and being naturally prefumptunus take very littlecare to guard againft a furprize. They place great confidence in their Manitous; or hourhold gods, which they always carry with them, and being perfuaded that they take upon them the office of centinels, they neep very fecurely under their protection.

Thefe Manitous, as they are called by fome nations, but which are termed Wakon, that is, fpirits, by the Naudoweffies, are nothing more than the otter and martins lkins I have already defcribed, for which", however, they have a great veneration.

After they have entered the enemies country, no people can be more cautious and circumfpect: fires are no longer lighted, no more Thouting is heard, nor the game any longer purfued They are not ceven permitted to fpeak; but nuft convey whatever they have to impart to each other by figns and motions.

They now proceed wholly by ftratagem and ambufcade. Having difcovered their enemies, they fend to reconnoitre them; and a council is immediately held, during which 


\section{$(292)$}

they fpeak only in whifpers, to sonfider of the intelligence imparted by thole who were fent out.

The attack is generally made juft before day-break, at which period they fuppofe their foes to be in the foundef fleep. Throughout the whole of the preceding night ihey will lie flat upon their faces, without 1tirring; and make their approaches in the fame. pofture, creeping upon their hands and feet. till they are got within bow-shot of thofe they have deftined to deftruction. On a pignal given by the chief warrior, to which the whole body makes anfwer by the moft hideous yells, they all ftart up, and difcharging their arrows in the fame inftant, without giving their adverfaries time to recover from. the confufion into which they are thrawn, pour in upon them with their war-clubs or tomahawks.

The Indians think there is litule glory to be acquired from attacking theil enemies openly in the field; their greateft pride is to furprize and deftroy. They feldom engage without a manifeft appearance of advantage. If they find the enemy on their guard, too ftrongiy entrenched, or fuperior in numbers, they retire, provided there is an opportunity 


\section{( 293 i}

of doing fo. And they efteem it the grateft qualification of a chief warrior, to be able to manage an attack, fo as to deftroy as many of the enemy as poffible, at the expence of a few men.

Sometimes they fecure themfelves behind trees, hillocks, or ftones, and having given one or two rounds retire befote they are difcovered. Europeans who are unacquainted with this method of fighting too often find to their coft the deftructive efficacy of it.

General Braddock was one of this unhappy number. Marching in the Year I 755, to attack Fort Da Quefne, he was intercepted by a party of confederate Indians in the intereft of the French, who by this infidious method of engaging found means to defeat his army, which confifted of about three thoufand brave and well difciplined troops. So fecurely were the Indians pofted, that the Englifh fcarcely knew from whence or by whom they were thus annoyed. During the whole of the engagement the latter had fcarcely a fight of an enemy; and were obliged to retreat without the fatisfaction of being able to take the leaft degree of revenge for the havock made among them The general paid for his temerity with his life, and 


\section{( 294$)$}

arid was accompanied in his fall by a great number of brave fellows; whilf his invifible enemies had only two or three of their number wounded.

When the Indians fucceed in their filent approaches, and are able to force the camp which they attack, a fcene of horror, that exceeds defcription, enfues. The favage fiercenefs of the conquerors, who well know what they have to expect fhould they fall alive into the hands of their affailants, occafion the moft extraordinary exertions on both fides. The figure of the combatan all befineared with black and red paint, and covered with the blood of the Alain, their horrid yells, and ungovernable fury, are not to be conceived by thofe who have never croffed the Atlantic.

I have frequently been a fpectator of them, and once bore a part in a fimiiar fcene But what added to the horror of it, was, that I had not the confolation of being able to oppofe their favage attacks. Every circumftance of the adventure ftill dwells on my remembrance, and enables me to defcribe with greater perficuity the bru al fiercenefs of the Indians when they have furprized or overpowered an enemy. 


\section{( 295)}

As a detail of the maffacre at Fort William Henry in the year 1757 , the fcene to which I refer, cannot appear foreign to the defign of this publication, but will ferve to give my readers a juft idea of the ferocity of this people, I thall take the liberty to infert it, apologizing at the famc time for the length of the digreffion, and thofe egotifins which the relation renders unavoidable.

General Webb, who commanded the Englifh army in North America, which was then encamped at Fort Edward, having intelligence that the French troops under Monf. Montcalm were making fome movements towards Fort William Henry, he detached a corps of about fifteen hundred men, confifting of Englifh and Provincials, to ftrengthen the garrifon. In this party I went as a volunteer among the latter.

The apprehenfions of the Englin general were not without foundation; for the day. after our arrival we faw Lake George (formerly Lake Sacrament) to which it lies contignous, covered with an immenfe number of boats; and in a few hours we found our lines attacked by the French general, who had juft landed with eleven thoufand regulars and Canadians, and two thoufand Indians. Co- 


\section{( $(996)$}

lonel Monro, a brave gfficer, commanded in the fort, and had no more than two thoufand three hundred men with him, our detachment included.

With thefe he made a gallant defence, and probably would have been able at laft to preferve the: Fort, had he been properly fupported, and permitted to continue his efforts. On every fummons to furrender fent by the French general, who offered the moft honourable terms, , is anfwer repeatedly was, That he yet. found hil. $f$ in a condition to repel the moft vigorous attacks his befiegers were able to make; and if he the ught his prefent force infufficient, he could foon be fupplied with a greater number from the adjacent army:

But the colonel having acquainted General Webb with his fituation, and defired he would fend him fome froin troops, the general difpatched a meffenger to him with a letter, whe ein he informed him that it was not in his power to affift him, and therefore gave. him orders to furfender up the fort on the beft terms he could procure. This packet fell into the hands of tle French general, who inmediately fent a flag of truce, defir-? ipg a confcrence with the governor. 


\section{( 297 )}

They accordingly met, attended only by a fmall guard, in the centre between the lines; when Monf. Montcalin told the colonel, that he was come in perfon to demand poffeflion of the fort, as it belonged to the king his mafter. "The colonel replied, that he knew not how that could be, nor fhould he furrender it up whilft it was in his power to defend it.

The French general rejoined, at the fame time delivering the packet into the colonel's hand, By this authority do I make the re"quifition." The brave governor had no fooner read the contents of it, and was convinced that fuch were the orders of the commander in chief, and not to be difobeyed, than he hurig his head in filence, and reluctantly entered into a negociation.

In confideration of the gallant defence the garrifon had made, they were to be permitted to march out with all the honours of war, to bo allowed covered waggons to tranfport their baggage to Fort Edward, and a guard to protect them from the fury of the favages.

The morning after the capitulation was figner, as foon as day broke, the whole garrifon, now confifting of about two thoufand men, befides women and children, were drawn 


\section{( 298$)$}

up within the lines, and on the point of marching off, when great numbers of the Indians gathered about, and began to plunder. We were at firf in hopes that this was their only view, and fuffered them to proceed without oppofition. Indeed it was not in our power to make any, had we been fo inclined; for though we were permitted to carry off our arms, yet we were not allowed a fingle round of ammunition. In thefe hopes however we were difappointed; for prefently fome of them began to attack the fick and wounded, when fuch as were not able to crawl into the ranks, notwithftanding they endeavoured to avert the fury of their enemies by their Ahrieks or groans, were foon difpatched.

Here we were fully in expectation that the difturbance would have concluded; and our little army began to move; but in a mort time we faw the front divifion driven back, and difcovered that we were entirely encircled by the favages. We expected every moment that the guard, which the French, by the articles of capitulation, had agreed to allow us, would have arrived, and put an end to our apprehenfions; but none appeared. The Indians now began to frip every one without exception, of their arms and cloaths, and thore who 


\section{( 299$)$}

who made the leaft refiftance felt the weight of their tomahawks.

I happened to be in the rear divifion, but it was not long before I thared the fate of my companions. Three or four of the favages laid hold of me, and whilft fome held their weapons over my head, the others foon dif-: robed ine of my coat, waiftcoat, hat, and buckles, omitting not to take from me what money I had in my pocket. As this wastranfacted clofe by the paffage that led from the lines on to the plain, near which a French centinel was pofted, I ran to him and claimed his protection; but he only called me an Englifh dog, and thruft me with violence back again into the midft of the Indians.

I now endeavoured to join a body of our troops that were crowded together at fome diftance, but innumerable were the blows that were made at me with different weapons as I paffed on; luckily however the favages were fo clofe together, that they could not ftrike at me without endangering each other. Notwithltanding which one of them found means to make a thruft at me with a fpear, which grazed iny fide, and from another.I received a wound, with the fame kind of weapon, in my ankle. At length I gained the 


\section{$(300)$}

fpot where my countrymen food, and forced myfelf into the midft of them. But before I got thus far out of the harids of the Indians, the collar and wriftbands of my flirt were all that remained of it, and iny fle $h$ was fcratched and torn in many places by their favage gripes.

By this time the war-hoop was given, and the Indians began to murner thofe that were neareft to them without diftinction. It is not in the power of words to give any tolerable idea of the horrid fcene that now enfued; men, women, and children were difpatched in the moft wanton and cruel manner, and immediately fcalped. Many of thefe favages drank the blood of their victims, as it flowed warm from the fatal wound.

We now perceived, though toolate to a vail us, that we were to expect no relief from the French; and that, contrary to the agteement they had fo lately figned to allow us a fufficient force to protect us from thefe infults, they tacitly permitted them; for I could plaitily perceive the French officers walking about at fome diftance; difcourfing together with apparent unconcern. For the honour of human nature I would hope that this flagrant breach of every facred law, proceeded rather 


\section{$($ sor $)$}

from the farage difpolition of the Indian, which $I$ acknowledge it is fometimes almoft $i_{1}$ offible to controul, and which might now unexpectedly have arrived to a pitch not cally to be refrained, than to any preneditated defign in the French commander. An unprejudiced abferver would, however, be apt to conclude, that a body of ten thoufand Chriftiantroups, moft Chriftian troops, had it in their power to prevent the maffacre from becoming fo general. But whatever was the caufe from which it arofe, the confequences of it were dreadful, and not to be paralleled in modern hiftory

As the circle in which I ftood inclofed by this time was much thinned, and death feemed to be approaching with bafty frides, it was propofed by fome of the most tcfolite to inake Qne vigorous effort, and endeavour to force our way, though the favages, the only pro bable methot of preferving our livies that: now remained. This, however detpcrate, was refolved $a n_{x}$ and about twenty of us: fprung at ance into the midif of them.

In a moinent we werc all feparated and What was the fate of my companions I could not learn till fome mont hs after, when I found that only fix or ieven of them cficeted their dengn, 


\section{(302)}

defign. Intent only on my own hazardous fituation, I endeavoured to make my way through my favage enemies in the beft manner poffible. And $I$ have often been aftonifhed fince, when I have recollected with what compofure I took, as I did, every neceffary ftep for my prefervation. Some I overturned, being at that time young and athletic, and others I paffed by, dexteroufly avoiding their weapons; till at laft two very ftout chiefs, of the moft favage tribes, as I could diftinguinh by their drefs, whofe ftrength $I$ could not refift, laid hold of me by each arm, and began to force me through the crowd.

I now refigned myfelf to my fate, not doubting but that they intended to difpatch $\mathrm{me}$, and then to fatiate their vengeance with my blood, as I found they were hurrying me towards a retired fwamp that lay at fome diflance. But before we had got many yards, an Englifh gentleman of fome diftinction, as I could difcover by his breeches, the only covering he had on which were of fine fcarlet velvet, rufhed clofe by us. One of the Indians inftantly relinquifhed his hold, and fpringing on this new object, endeavoured to feize him as his prey; but the gentleman being 


\section{( 303 )}

Atrong, threw him on the ground, and would probably have got away, had not he who held my other arm, quitted me to affift his brcther. I feized the opportunity, and haftened away to join another party of Englifh troops that were yet unbroken, and ftood in a body at fome diftance But before I had taken many fteps ; I haftily caft my eyes to-: wards the gentleman, and faw the Indian's, tomahawk gath into his back, and heard him utter his laft groan; this added both to my speed and defperation.

I had left this thocking fcene but a few yards, when a fine boy about twelve years of age, that had hitherto efcaped, came up to me, and begged that I would let him lay hold of me, fo that he might ftand fome chance of getting out of the hands of the favages. I told him that I would give him every affiftance in my power, and to this purpofe bid him lay hold; but in a few moments he was torn from my fide, and by his Ihrieks, I judge was foon demolihed. I could not help forgetting my own cares for a minute, to lament the fate of fo young a fufferer ; but it was utterly impoffible for me to take any methods to prevent it.

I now 


\section{( 304 :)}

I now got once more into the midit of friends, but we were unable to afford each other any fuccour: As this was the divifion that had advanced the furtheff from the fort, I thought there inight be a poffibility (though but a very bare one) of my forcing a way through the outer ranks of the Indians; and getting to a neighbouring wood, which I perceived at fome diftance. I was ftill encorraged to hope by the almof miraculous prefervation.I had already experienced.

Nor were my hopes vain, or the effort 1 made ineffectual. Suffice it to fay that 1 reached the wood, but by the time I had penetrated a little way into it, my breath:

fo exhaufted that I threw my felf into a brake, and lay for fome minutes apparently at the laft gafp. At length I recovered the power of refpiration, but my apprehenfions réturned with all their former force, when $I$ faw feveral favages pals by, probably in purt fuit of me, at no very great diftance. In this fituation / knew not whether it was better to proceed, or endeavour to conceal myfelf where lajy, till night came on, fearing, however, that they would return the fame way, I thought it moft prudent to get farther from the dreadful feenc of my paft diftreffes. Accordingly, 


\section{(305i)}

cordingly, ftriking into another part of the wood; I haftened on as falt as the briars and the lofs of one of my thoes would permit me; and after a flow progrefs of fome hours, gained a hill that overlooked the plain which I had juft left, from whence I could difcern that the bloody ftorm ftill raged with unabated fury.

But not to tire my readers, I thall only add, that after piffing three days without fubfiftence, and enduring the feverity of the cold dews for three nights, 1 at length reached Fort Edward; where with proper care my body foon recovered its wonted ftrength, and my mind, as far as the recollection of the tate melancholy events would permit, its ufual compofure.

It was computed that fifteen hundred perfons were killed or made prifoners by thefe favages during this fatal day. Many of the latter were carried off by then and never returned. A few, through favourable accidents, found their way back to their native country, after having experienced a long and fevere captivity.

. The brave Colonel Monro had haftened away, foon after the confufion began, to the French camp to endeavour to procure the Acigly, 


\section{( 306$)$}

guard agreed by the Itipulation; but his application proving ineffectual, he remained there till General Webb fent a party of troops to demand and protect him back to Fort Edward. But the fe unhappy occurrences, which would probably have been prevented, had he been left to purfue his own plans, toge her with the lofs of fo many brave fellows, murdered in cold blood, to whofe valour he had been fo lately a witnefs, made fuch an impreffion on his mind, that he dia not long furvive. He died in about three months of a broken heart, and with truth might it be faid, that he was an honour to his country.

I mean not to point out the following circumftances as the immediate judgment of heaven, and intended as an atonemerit for this naughter, but 1 cannot omit that very few of thofe different tribes of Indians that thared in it ever lived to return home. The fmall pox, by mears of their communication with the Europeans, found its way among them, and made an equal havock to what they themfelves had done. The methods they purfued on the firft attack of that malignant diforder; to abate the fever attending it, rendered it fatal. Whilft their blood was in: a 


\section{$(307)$}

ftate of fermentation, and nature was friving i5 throw out the peccant matter, they checked her operations by plunging inte the water: the confequence was, that they died by hundreds. The few that furvived were tranfformed by it into hideous objects, and bore with them to the grave deep indented marks of this much-dreaded difeafe.

Monfieur Montcalm fell foon after on the plains of Quebec.

That the unprovoked cruelty of this commander 'was not approved of by the generality of his countrymen, I have fince been convinced of by many proofs. One only however, which I received from a perfon who was witners to it, thall $\mathrm{I}$ at prefent give. $\mathrm{A} \mathrm{Ca-}$ nadian mercinant, of fome confideration, having heard of the furrender of the Englifh Fort, celebrated the fortunate event with great rejoicings and hofpitality, according to the cuftom of that country; but no fooner did the news of the maffacre which enfined reach his ears, than he put an immediate fop to the feftivity, and exclaimed in the fevereft terms againft the inhuman permiffion; declaring at the fame time that thofe who had connived at it, had thereby drawn down on that part of their king's dominions the ven$\mathrm{X}_{2}$ geance 


\section{( 308$)$}

geance of heaven. To this he added, that he much feareci the total lofs of them would defervedly be the confequence. How truly this prediction has been verified we all know.

But to return: though the Indians are negligent in guarding againft furprizes, they are alert and dextrous in furprizing their enemies. To their caution and perfeverance in ftealing on the party they defign to attack, they add that admirable talent, or rather inftinctive qualification, I have already defcribed, of tracing out thofe they are in pursuit of. On the fmootheft grafs, on the hardeft earth, and even on the very fones, will they difcover the traces of an enemy, and by the Thape of the footfteps, and the diftance between the prints, diftinguifh not only whether it is a man or a woman who has paffed that way, but even the nątion to which they belong. However incredible this might appear, yet from the many proofs I received whilft among them of their amazing fagacity in this point, I fee no reafon to difcredit even thefe extraordinary exertions of it.

When they have overcome an enemy and vichory is no longer doubtful, the conquerors firft difpatch all fuch as they think they thall 


\section{( 309$)$}

not be able to carry off without great trouble, and then endeavour to take is many prifoners as poffible; after this they return to fcalp thufe who are either dead, or too much wounded to be taken with ihem.

At this hufinefs they are exceedingly expert. They feize the head of the difabled or dead enemy, and placing one of their feet on the neck, twift their left hand in the hair; by this means, having extended the 1 kin that covers the top of the head, they draw out their fcalping knives, which are always kept in good order for this cruel purpofe, and with a few dextrous ftrokes take off the part that is termed the fcalp. They are fo expeditious in doing this, that the whole time required fcarcely exceeds a minute. Thefe they preferve as monuments of their prowefs, and at the fame time as $\mathrm{pr}$ fs of the vengeance they have inflicted on their encmies.

If two Indians feize in the fame inftant a prifoner, and feem to have an equal claim, the conteft between them is foon decided; for to put a fpeedy end to any difpute that might arife, the perfor that is apprehenfive he fhall lofe his expected reward, immediately has recourfe to his tomahawk or war-club, and 


\section{(310)}

and knocks on the head the unhappy caufe of their contention.

Having completed their purpofes, and made as much havock as poffible, they immediately retire towards their own country, with the fpoil they have acquired, for fear of being purfued.

Should this be the cafe, they make ufe of many ftratagems to clude the iearches of their purfuers. They fometimes fcatter leaves: fand, or duft over the prints of their feet; fometimes tread in eacn others footfteps; and fometimes lift their feet fo high, and tread fo lightly, as not to make any impreffion on the ground. But if they find all thefe precautions unavailing, and that they are near being overtaken, they firft difpatch and fcalp their prifoners, and then dividing, each endeavours to regain his native country by a different route. This prevents all farther purfuit; for their purfuers now defpairing; either of gratifying their revenge, or of releafing those of their friends wir were made captives, return home:

If the fuceefsful party is fo lucky as to make good their retreat unmolefted, they hafien with the greateft expedition to reach a country where they may be perfectly fecure; 


\section{( 3il )}

and that their wounded companions may not retard their flight, they carry them by turns in litters, or if it is in the winter feafon draw them on lledges.

Their litters are made in a rude manner of the branches of trees. Their fledges confift of two fmall thin boards about a foot wide when joined, and near fix feet long. The fore part is turned up, and the fides are bordere! with fmall bands. The Indians draw thefe carriages with great eafe be they ever fo much loaded, by means of a ftring which paffes round the breaft. This collar is called a Metump, and is in ufe throughout Anerica, both in the fettlements and the internal parts. Thofe ufed in the latter are made of leather and very curiounly wrought.

The prifoners during their march are guarded with the greateft care. During the day, if the journey is over land, they are always held by fome of the victorious party; if by water, they are faftened to the canoe. In the night-time they are fretched along the ground quite naked, with their legs, arms, and neck faftened to hooks fixed in the ground. Befides this, cords are tied to their arms or legs, which are held by an Indian, 


\section{(312)}

dian, who inftantly awakes at the leaft mo tion of them.

Notwithftanding fuch precautions are ufually taken by the Indians, it is recorded in the annals of New England, that one of the weaker fex, almoft alone, and unaffifted, found means to elude the vigilance of a party of warriors, and not only to make her efcape from them, but to revenge the caufe of her countrymen.

$\therefore$ Some years ago, a fmall band of Canadian Indians, confifting of ten warriors attended by two of their wives, made an irruption into the back fettlements of New England. They lurked for fome time in the vicinity of one of the moft extericr towns, and at length after having killed and fcalped feveral people, found means to take prifoner a woman who had with her a fon of about twelve years of age. Being fatisfied with the execution they had done, they retreated towards their native country, which lay at three hundred miles diftance, and carried off with them their two captives:

"The fecond night of their retreat, the woman, whore namie if I miftake not was Rowe, formed a refolution worthy of the moit intrepid hero. She thought Ase should be

In

m

hi

th

fe

$\mathrm{B}$

im

ftr

at

hi 


\section{( 3. 3. )}

be able to get from her hands the manacles by which they were confined, and determined if the did fo to make a defperate effort for the recovery of her freedom. To this purpofe, when the concluded that her conquerors were in their foundeft fleep, the ftrove to lip the cords from her hands. In this the fucceeded; and cautioning her fon, whom they had fuffered to go unbound, in a whifper, againft being furprized at what the was about to do, the removed to a diftance with great warinefs the defenfive weapons of the Indians, which lay by their fides.

Having done this, ahe put one of the tomahawks into the hands of the boy, bidding him to follow her example; and taking another herfelf, fell upon the fleeping Indians, feveral of whom the inftantly difpatched. But her attempt was nearly fruftrated by the imbecility of her fon, who wanting both ftrength and refolution, made a feeble froke. at one of them which only ferved to awaken. him; The however fprung at the rifing warrior, and before he could recover his arms, made him fink under the weight of her tomahawk; and this the alternately did to all the reft, except one of the women, who awoke in time, and made her efcape. 


\section{( 314$)$}

The heroine then took off the fcalps of her vanquifhed enemies, and feizing alfo thofe they were carrying away with them as proofs of their fuccefs, the returned in triumph to the town from whence the had fo lately be $\mathbf{n}$ dragged, to the great aftonimment of her neighbours, who could fcarcely credit their fenfes, or the teftimonies the bore of her Amazonian intrepidity.

During their march they oblige their prifoners to fing their death-fong, which generally confifts of thefe or fimilar fentences. "I am going to die, I am about to fuffer; but "I will bear the fevereft tortures my ene" mies can inflict with becoming fortitude. $\mathbf{I}$ "will die like a brave man, and I thall then "go to join the chiefs that have fuffered on "the fame account." Thef fongs are continued, with neceffary intervals, until they reach the village or camp to which they are going.

When the warriors are arrived within hearing, they fot up different cries, which communicates to their friends a general hiftory of the fuccers of the expedition. The number of the death-cries they give, declares how many of their own party are loft; the number 


\section{( 315$)$}

number of war-hoops, the number of prifoners they have tiken.

It is difficult to defcribe thefe cries, but the beft idea I can convey of them, is that the former confints of the found Whoo, Whoo, Whoop, which is continued in a long ihrill tone, nearly till the breath is eis rufted, and then broken off with a fudden elevation of the voice. The latter of a loud cry, of much the fame kind, which is modulated into notes by the hand being placed before the mouth, Both of them might be heard to a very confiderable diftance.

Whilf thefe are uttering, the perfons to whom they are defigned to convey the intelligence, continue motionlefs and all attention. When this ceremony is performed, the whole village iffue out to learn the particulars of the relation they have juft heard in general terms, and according as the news proves mournful or the contrary, they anfwer by fo many acclamations or cries of lamentation.

Being by this time arrived at the village or camp, the women and children arm themfelves with fticks and bludgeons, and form themfelves into two ranks, through which the prifoners are obliged to pafs. The trcatment they 


\section{$\left(3^{16}\right)$}

they undergo before they reach the extremity of the line, is very fevere. Sometimes they are fo beaten over the head and face, as to have fcarcely.any temains of life; and happy would it be for them if by this ufage an end was put to their wretched beings. But their tormentors take care that none of the blows they give prove mortal, as they wifh to referve the miferable fufferers for more fevere inflictions.

After having undergone this introductory difcipline, they are bound hand and foot, whilft the chiefs hold a council in which their fate is determined. Thofe who are decreed to be put to death by the ufual torments, are delivered to the chief of the warriors; fuch as are to be fpared, are given into the hands of the chief of the nation : fo that in a fhort time all the prifoners may be affured of their fate, as the fentence now pronounced is irrevocable. The former they term being configned to the houfe of death, the latter to the houfe of grace.

Such captives as are pretty far advanced in life, and have acquired great honour by their warlike deeds, always atone for the Hlood they have fyilt by the tortures of fire. Their fuccess in war is readily known by the blue 


\section{( 317$)$}

blue marks upon their breafts and arms, which are as legible to the Indians as letters are to Europeans. .

The manner in which thefe hieroglyphicks are made, is by breaking the Akin with the teeth of firh, or harpened flints, dipped in a kind of ink made of the foot of pitch pine. Like thofe of the ancient Picts of Britain thefe are efteemed ornamental; and at the fame time they ferve as regifters of the heroic actions of the warrior, who thus bears about him indelible marks of his valour.

The prifoners deftined to death are foon led to the place of execution, which is generally in the centre of the camp or village; where, being ftript, and every part of their bodies blackened, the Akin of a crow or raven is fixed on their heads. They are then bound to a ftake, with faggots heaped around them, and obliged, for the laft time, to fing their death-fong.

The warriors, for it is fuch only who commonly fuffer this punifhment, now perform in a more prolix manner this fad folemnity. They recount with an audible voice all the brave actions they have performed, and pride themfelves in the number of enemies they have killed. In this rehearfal they 


\section{( 318$)$}

fpare not even their tormentors,' but ftrive by every provoking tale they can invent, to irritate and infult them. Sometimes this has the defired effect, and the fufferers are difpatched fooner than they otherwife would have been.

There are many other methods which the Indinns malse ufe of to put their prifoners to death, but thefe are only occafional; that of burning is moft generally ufed.

Whilf I was at the chief town of the Ottagaumies, an Illinois Indian was brought in, who had been made prifoner by one of the ir war parties. I had then an opportunity of feeing the cuftomary cruelties inflicted by thefe people on their captives, through the minuteft part of their procefs. After the previous fteps neceffary to his condemnation, he was carried, early in the morning, to a little diftance from the town, where he was. bound to a tree.

This being done, all the boys, who amounted to a great number, as the place was populous, were permitted to amufe themfelves with thooting their arrows at the unhappy victim. As they were none of them more than twelve years:old, and were placed at a confiderable diftance, they had not:Atrength 


\section{( 31.9 )}

to penetrate to the vital parts, fo that the poor w retch ftood pierced with arrows, and fuffuring the confequent agonies, for more than two days.

During this time he fung his warlike exploits. He recapitulated every ftratagem he had made ufe of to furprize his enemies; he boafted of the quantity of fcalps he poffeffed, and enumerated the prifoners he had taken. He then defcribed the difierent barbarous methods by which he had put the latter to death, and feemed even then to receive inconceivable pleafure from the recital of the horrid tale.

But he dwelt more particularly on the cruelties hehad practifed on fuch of the kindred of his prefent tormentors as had fallen into his hands; endeavouring by thefe aggravated infults to induce them to increafe his tortures, that he might be able to give greater proofs of fortitude. Even in the laft ftriggles of life, when he was no longer able to vent in words the indignant provocation his tongue would have uttered, a fmile of mingled fcorn and triumph fat on his countenance.

This method of tormenting their enemies is confidered by the Indians as productive of 


\section{( 320$)$}

nore than one beneficial confeccuence. It fatiates, in a greater degree, that diabolical luft of revenge, which is the predominant paffion in the breaft of cvery individual of every tribe, and it gives the growing warriors an early propenfity to that cruelty and thirft for biosd, which is fo neceffary a qualifica. tion for fuch as would be thoroughly fkilled in their favage art of war.

I have been informed, that an Indian who was under the hands of his tormentors, had the audacity to tell them, that they were ig- . norant old women, and did not know how to put brave prifoners to death. He acquainted them that he had heretofore taken fome of their warriors, and inftead of the trivial punifhments they inflicted on him, he had devifed for them the molt excruciating torments: that having bound them to a ftake, he had ftuck their bodies full of fharp fplinters of turpentine wood, to which he then fot fire, and dancing around them enjoyed the agonizing pangs of the flaming victims.

This bravado, which carried with it a degree of infult that even the accurtorned ear of an Indian could not liften to unmoved; threw his tormentors off their guard, and Mortenec the duration of his torments; for

diar thei

are

the

eve:

witl fpec tude the $I$ erci

owr

trib

moc

ing

to $b$

ty $h$

and

milc

by

and Inft 


\section{( 321$)$}

one of the chiefs ran to him, and ripping out his heart, ftopped with it the mouth from which had iffued fuch provoking language.

Innumerable are the ftories that may be told of the courage and refolution of the Indians, who happen to be made prifoners by their adverfaries. Many that I have heard are fo aftonifhing, that they feem to exceed the utmoft limits of credibility; it is, however, certain that thefe favages are poffeffed with inany heroic qualities, and bear every fpecies of misfortune with a degree of fortitude which has not been outdone by any of the ancient heroes of either Greece or Rome.

Notwithftanding thefe acts of feverity exercifed by the Indians towards thofe of their own fpecics who fall into their hands, fome tribes of them have been remarked for their moderation to fuch female prifoners belonging to the Englin colonies as have happened. to be taken by them. Women of great beauty have frequently been carried off by them, and during a march of three or four hundred miles, through their retired forcfts, have lain by their fides without receiving any infult, and their chaftity has remained inviolate." Inftances- have happened where female cap-." 


\section{$(322)$}

tives, who have been pregnant at the time of their being taken, have found the pangs of child-birth come upon them in the midft of folitary woods, and favages their only companions; yet from thefe, favages as they were, have they received every affiftance their fituation would admit of, and been treated with a degree of delicacy and humanity they little expected.

This forbearance, it muft be acknowledged, does not proceed altogether from their difpofitions, but is only inherent in thofe who have held fome communication with the French miffionaries. Without intending that their natural enemies the Englifh fhould enjoy the benefit of their labours, thefe fathers have taken great pains to ince.rie on the minds of the Indians the general principles of humanity, which has diffufed itfelf through their manners, and has proved of public utility.

Thofe prifoners that are configned to the houfe of grace, and thefe are commonly the young men, women, and children, await the difpofal of the chiefs, who after the execution of fuch as are conciemned to die, hold a council for this purpofe.

A herald 


\section{( 323$)$}

A herald is fent round the village or camp, to give notice that fuch as have loft any relation in the late expedition are defired to attend the diftribution which is about to take place Thofe women who have loft their fons or hufbands are : generally fatisfied in the firft place; after thefe, fuch as hive been deprived of friends of a more remote degree of confanguinity, or who chofe to adopt fome of the youth.

The divifion being made, which is done, as in other cafes, without the leaft difpute, thofe who have received any fhare lead them to their tents or huts; and having unbound thern, wanh and drefs their wounds if they happen to have received any; they then cloath them, and give them the moft comfortable and refreshing food their fore will afford.

Whilft their new domefticks are feeding, they endeavour to adminifter confolation to them; they tell them that as they are redeemed from death, they muft now be cheet $\rightarrow$ ful and happy; and if they ferve them well, without murmuring or repining, nothing Thall be wanting to make them fuch atonement for the lofs of their country and friends, as circuinftances will allow of. 


\section{( 324$)$}

If any men are fpared, they are commonly given to the widows that have loft their hufbands by the hand of the enemy, thould there be any fuch, to whom if they happen to prove agreeable, they are foon married. But hould the dame be otherwife engaged, the life of him who falls to her lot is in great danger; efpecially if the fancies that her late hufband wants a llave in the country of fpirits to which he is gone.

When this is the cafe, a number of young men take the devoted captive to fome diftance, and difpatch him without any ceremony: after he has been fpared by the council, they confider him of too little confequence to be intitled to the torments allotted to thofe who have been judged worthy of them.

The women are ufually diftributed to the men, from whom they do not fail of meeting with a favourable reception. The boys and girls are taken into the families of fuch as have need of them, and are confidered as flaves; and it is not uncommon that they are fold in the fame capacity to the European. traders who come among them.

The Indians have no idea of moderating the ravages of war, by fparing their prifoners,

and

banc

an

both

or $n$

ever

their

prifo

hour

or a

efca!

or ac

T]

fers

dren

The

place

diffic

their

any

and

ed as

fons

their

ed $\mathrm{v}$

$T$

fider

amo and 


\section{( 325$)$}

and entering into a negotiation with the band from whom they have been taken, for an exchange. All that are captivated by both parties; are either put to death, adopted, or made llaves of. And fo particular are every nation in this refpect, that if any of their tribe, even a warrior, fhould be taken prifoner, and by chance be received into the houfe of grace, either as an adopted perfon or a flave, and fhould afterwards make his efcape, they will by no means receive him, or acknowledge him as one of their band.

The condition of fuch as are acopted differs not in any one inftance from the children of the nation to which they now bclong. They affume all the rights of thofe whofe places they fupply, and frequently make no difficulty of going in the war-parties againft their own countrymen. Should, however, any of thefe by chance make their efcape, and be afterwards retaken, they are efteemed as unnatural children and ungrateful perfons, who have deferted and made war upon their parents and benefactors, and are treated with uncommon feverity.

That part of the prifoners which are confidered as flaves, are generally diftributed among the chiefs; who frequently make pre- 


\section{( 326$)$}

fents of fome of them to the European governors of the out-pofts, or to the fuperintendants or commiffaries of Indian affairs. I have been informed that it was the Jefuits, and French miffionaries that firft occafioned the introduction of thefe unhappy captives into the fettlements, and who by fo doing taught the Indians that they were valuable.

Their views indeed were laudable, as they imagined that by this method they mould not only prevent much barbarity and bloodhed, but find the opportunities of fpreading their religion among them increafed. To this purpofe they encouraged the traders to purchafe fuch naves as they met with.

The good effects of this mode of proceeding was not, however, equal to the expectations of thefe pious fathers. Inftead of being the means of preventing cruelty and bloodhed, it only caufed the diffenfions between the Indian nations to be carried on with a greater degree of violence, and with unremitted ardour. The prize they fought for being no longer revenge or fame, but the acquirement of fpirituous liquors, for which their captives were to be exchanged, and of which almoft every nation is immoderately fond, they fought for their enemies with un

their

creafe

to the

for $a$

order

put a

de Bo

cland

annes

confic

Son

of it 


\section{( 327$)$}

wonted alacrity, and were confantly on the watch to furprize and carry them off.

It inight ftill be faid that fewer of the captives are tormented, and put to death, fince thefe expectations of receiving fo valuable a confideration for them have been excited, than there ufually had been; but it does not appear that their accuftomed cruelty to the warriors they take, is in the leaft abated; their natural defire of vengeance muft be gratified; they are now only become more affiduous in fecuring a greater number of young prifoners, whilit thofe who are made captive in their defence are tormented and put to death as before.

The miffionaries finding that contrary to their withes their zeal had only ferved to encreafe the fale of the noxious juices, applied to the governor of Canada in the ycar 1693, for a prohibition of this baneful trade. An order was iffued accordingly, but it could not put a total ftop to it ; the French Couriers de Bois were hardy enough to carry it on clandeftincly, notwithftanding the penalty annexed to a breach of the prohibition was a confiderable fine and imprifonment.

Some who were cietected in the profecution of it withdrew into the Indian countries, where 


\section{( 328$)$}

where they intermarried with the natives and underwent a voluntary baniminent. Thefe, however, being an abandoned and debauched fet, their conduct contributed very little either towards reforming the manners of their new relations, or engaging them to entertain a favourable opinion of the religion they profeffed...Thus did thefe indefatigable religious men fee their defigns in fome meafure once more fruftrated.

However, the emigration was productive of an effect which turned out to be beneficia! to their nation. By the connection of there refugees with the Iroquois, Miffiffagues, $\mathrm{Hu}$ rons, Miamies, Powtowottomies, Puants, Menomonies, Algonkins, \&c. and the conftant reprefentations thefe various nations received from them of the power and grandeur of the French, to the aggrandizement of whofe monarch, notwithftanding their banifhment, they ftill retained their habitual inclination, the Indians became infenfibly prejudiced in favour of that people, and I am perfuaded will take every opportunity of thewing their attachment to them.

And this, even in defpite of the difgraceful efimation they muft be held by them, fince they have been driven out of Canada; for the

Indi: in a :

ter c

and is $\mathrm{cu}$ whe: to that ough parti too c

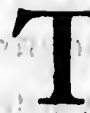

redi

a fe ceffo to a adva V to a com if it Indians 


\section{( 329$)$}

Indians confider qvery conquered people as in a ftate of vaffalage to their conquerors. After one nation has finally fubdued another, and a conditional fubmifion is agreed on, it is cuftomary for the chiefs of the conquered, when they fit in council with their fubduers, to wear petticoats, as an acknowledginent that they are in a ftate of fubjection, and ought to be ranked among the women. Their partiality to the French has however taken too deep root, for time itfelf to eradicate it.

\section{H A P. X.}

Of their manner of making $\mathrm{PEACE}_{\mathrm{E}} \mathcal{E}^{\circ} c$.

$7 \mathrm{HE}$ wars that are carried on between reditary and continue from age to age with a few interruptions. If a peace becomes neceffary, the principal care of both parties is to avoid the appearance of making the firft advances.

When they treat with an enemy, relative to a furpenfion of hoftilities, the chief who is commiffioned to undertake the negotiation, if it is not brought about by the mediation of fome 


\section{( 330$)$}

fome neighbouring band, abates nothing of his natural haughtinefs : even when the affairs of his country are in the worft lituation, he makes no conceffions, but endeavours to perfuade his adverfaries that it is their intereft to put an end to the war.

Accidents fometimes contribute to bring about a peace, between nations, that otherwife could not be prevailed on to liften to terms of accommodation. An inftance of this, which I heard of in almoft every nation I paffed through, I thall relate.

About eighty years ago, the Iroquois and Chiféways, two powerful nations, were at war with the Ottagaumies and Saukies, who were much inferior to their adverfaries both in numbers and ftrength. One winter near a thoufand of the former made an excurfion from Lake Ontario, by way of 'Toronto, to-' wards the territories of their enemies. They coafted Lake Huron on its eaft and northern borders, till they arrived at the ifland of St. Jofeph, which is fituated in the fraights of St. Marie. There they croffed thefe fraights upon the ice about fifteen miles below the falls, and continued their route ftill weftward. As the ground was covered with fnow, to prevent a difcovery of their numbers, they

march

footft

For obrery the di tions they

Nol belon: and in a prir they forme hafter takin! the h fore 1 mann of $\mathrm{ab}$ whic the a

$\mathrm{Th}$ force to $b$ were impo they 


\section{( 331 )}

marched in a fingle file, treading in each others footfteps.

Four Chipéway Indians, paffing that way, obferved this army, and readily gueffed from the direction of their march and the precautions they took, both the country to which they were haftening, and their defigns.

Notwithftanding the nation to which they belonged was at war with the Ottagaumies, and in alliance with their invaders, yet from a principle which cannot be accounted for, they took an inftant refolution to apprize the former of their danger. To this purpofe they haftened away with their ufual celerity, and, taking a circuit to avoid difcovery, arrived at the hunting grounds of the Ottagaumies, before fo large a body, moving in fo cautious a manner, could do. There they found a party of about four hundred warriors, fome of which were Saukies, whom they informed of the approach of their enemies.

The chiefs immediately collected their whole force, and held a council on the fteps that were to be taken for their defence. As they were encumbered with their families, it was impoffible that they could retreat in time; they therefore determined to chufe the moft advantageous 


\section{( 332$)$}

advantageous fpot, and to give the Iroquois the beft reception in their power.

Not far from the place where they then happened to be, ftood two finall lakes, between which ran a narrow neck of land about a mile in length, and only from twenty to forty yards in breadth. Concluding that the Iroquois intended to pafs through this defile, the united bands divided their little party into two bodies of two hundred each. One of thefe took poit at the extremity of the pafs that lay neareft to their hunting grounds, which they immediately fortified with a breaft-work formed of palifades; whilf the other body took a compars round one of the lakes, with a defign to hem their enemies in when they had entered the defile:

Their Atratagem fucceeded; for no fooner had the whole of the Iroquois entered the pafs, than being provided with wood for the purpofe, they formed a fimilar breaft-work on the extremity, and thus enclofed their enemies.

'The Iroquois foon perceived their fituation, and immediately held a council on the meafures that were neceffary to be purfued to extricate themfelves. Unluckily for them, a thaw had juft taken place, which had fo far diffolved

dif

an

vel

on

dil

dea

the

eff

the

of

fou

ing

raf

trc

att

bu

ful

det

car

$\mathrm{TH}$

ou

res

the

fti 


\section{( 333$)$}

diffolved the ice as to render it impaffable, and yet there fill remained fufficient io prevent them from either paffing over the lakes on rafts, or from fwimming acrofs. In this dilemma it was agreed that they fhould endeavour to force one of the breaft-works; but they foon found them too well defended to effect their purpofe.

Notwithftanding this difappointment, with the ufual compofure and unapprehenfivenefs of Indians, they amufed themfelves three or four days in filhing. By this time the ice being quite diffolved, they made themfelves rafts, which they were enabled to do by fome trces that fortunately grew on the fpot, and attempted to crofs one of the lakes.

They accordingly fet off before day-break, but the Ottagaumies, who had been watchful of their motions perceiving their defign, detached one hundred and fifty men from cach of their parties, to oppofe their landing. Thefe three hundred marched fo expeditioully to the other fide of the lake, that they reached it before their opponents had gained the fhore, they being retarded by their poles fticking in the mud.

As foon as the confederates arrived, they poured in a very heavy fire, both from their 


\section{( 334 )}

bows and mufquetry, on the Iroquois, which greatly difconcerted them; till the latter finding their fituation defperate, leaped into the water, and fought their way through their enemies. This however they could not do without lofing more than half their men.

After the Iroquois had landed, they made good their retreat, but were obliged to leave their enemies mafters of the field, and in poffeffion of all the furs they had taken during their winter's hunt. Thus dearly did they pay for an unprovoked excurfion to fuch diftance from the oute they ought to have purfued, and to which they were only impelled by a fudden defire of cutting off fome of their ancient enemies.

But had they known their ftrength they might have deftroyed every man of the party that oppofed them; which even at the firft onfet was only inconfiderable, and, when diminimed by the action, totally unable to make any fand againft them.

The victorious bands rewarded the Clipeways who had becn the means of their fuccefs with a thare of the fpoils. They preffed them to take any quantity they chofe of the richert of the furs, and fent them, under an efcort of fifty men, to their own country. 


\section{( 335$)$}

The difinterefted Chipeways, as the Indians in general are feldom actuated by mercenary motives, for a confiderable time refufed thefe prefents, but were at length perfuaded to accept of them.

The brave and well-concerted refiftance here made by the Ottagaumies and Saukies, aided by the mediation of the. Chipéways, who laying afide on this occafion the animofity they had fo long borne thofe people, approved of the generous conduct of their four chiefs, were together the means of effecting a reconciliation between thefe nations; and in procefs of time united them all in the bands of ainity.

And I believe that all the Indians inhabiting that extenfive country, which lies between Quebec, the banks of the Miffiflippi north of the Ouifconfin, and the fettlements belonging to the Hudfon's Bay Company, are at prefent in a ftate of profound peace. When their reflefs difpofitions will not fuffer them to remain inactive, thefe northern Indians feldom commit hoitilities on each other, but make excurfions to the fouthward, againft the Cherokees, Chociahs, Chickafaws or Illinois.

Sometimes 


\section{$\left(33^{6}\right)$}

Sometimes the Indians grow tired of a war, which they have carried on againt fome neighbouring nation for many years without much fuccers, and in this cale they feek for mediators to begin a negotiation. Thefe being obtained, the treaty is thus conducied.

A number of their own chiefs, joined by thofe who have accepted the friendly office, fet out together for the country of their enemies; fuch as are chofen for this purpofe, are chicfs of the moft extenfive abilities and of the greateft integrity. They bear before them the pipe of peace, which I need not inform my readers is of the fame nature as a Flag of Truce among the Europeans, and is treated with the greateft refpeet and veneration, even $\mathrm{ty}_{\mathrm{y}}$ the moft barbarous nations. I never heard of an inftance wherein the bearers of this facred badge of friendhip were ever treated difrefpecifully, or its rights vio. lated. The Indians believe that the Great Spirit never fuficrs an infraction of this kind to go unpunifhed.

The pipe of peace, which is termed by the French, the Calumet, for what reafon I could never learn, is about four feet long.' The bowl of it is made of red marble, and the ftem of it of a light wood, curiounly painted

with $\mathrm{h}$ adorne tiful $b$ exact Plate I convey ing orr dian in

Eve decoral firft $f$ ufed a great $c$ occafio . The warrio feated, herbs fame ground that is is gene affemb As throws of it to the ca moves with 


\section{( 337$)$}

with hieroglyphicks in various colours, and adorned with the feathers of the moft beautiful birds. 1 have endeavoured to give as exact a reprefentation of it as poffible in Plate $N^{\circ}$. IV, but it is not in my power to convey an idea of the various tints, and plearing ornaments of this much efteemed Indian implement.

Every nation has a different method of decorating thefe pipes, and they can teil at firt fight to what band it belongs. it is ufed as an introduction to all treaties, and great ceremony attends the ufe of it on thefe occafions.

- The affiftant or aid-du camp of the great warrior, when the chiefs are affembled and feated, fills it with tobacco mixed with the herbs before mentioned, taking care at the fame time that no part of it touches the ground. When it is filled, he takes a coil that is thoroughly kindled from a fire which is generally kept burning in the midf of the affembly, and places it on the tobacco.

As foon as it is fufficiently lighted, he throws off the coal. He then turns the ftem of it towards the heavens, after this towards the earth, and now holding it horizontally moves himfelf round till he has conipleted a

$$
\mathrm{Z} \text { circle: }
$$




\section{( 338$)$}

circle: by the firft action he is fuppofed to prefent it to the Great Spirit, whofe aid is thereby fupplicated, by the fecond, to avert any malicious interpofition of the evil fpirits, and by the third to gain the protcciion of the Spirits inhabiting the air, the carth, and the waters. Having thus fec.red the favour of thofe invifible agents, in whofe power they fuppoie it is either to forward or obftruct the iffue of their prefent deliberations, he prefents it to the hereditary chief, who having taken two or three whiffs, blows the finoak from his mouth firft towaids heaven, and around him upon the ground.

It is afterwards put in the fame manner into the mouths of the ambaffations or ftrarigers, who obferve the fame ceremony; then to the chicf of the warriors, and to all the other chiefs in turn according to their gradation. During this time the perfon who executes this honourable oflice holds the pipe fightly in his hand, as if he feared to prefs the facred infirument; nor does any one preflime to teuc's it but with his lips.

When the chiefs who are intrufled with the commition for making peace, approach the town or camp to which they are going, they begin to fing and dance the fongs and dances

dances a time the arrival, wonted peace, is Great $\mathrm{C}$ convenie

A cor fpeeches tions ari painted imemoria contendi taken pl as have peans, a ftead of

A belt occafion, peace, al the hicr arc form tivaty.

Thefe coaits of are fawe about a r like othe 


\section{( 339$)$}

dances appropriated to this occafion. By this time the adverfe party are apprized of their arrival, and divefting themfelves of their wonted enmity at the fight of the pipc of peace, invite them to the habitation of the Great Chief, and furnim them with every conveniency during the negociation.

A council is then held; and when the fpeeches and debates are enced, if no obftructions arife to put a flop to the treaty, the painted hatchet is buried in the ground as a memorial that all animofities between the contending nations have ceafed, and a peace raken place. Among the ruder bands, fuch as have no communication with the Europeans, a war-ciub painted red is buricd inftead of the hatchet.

$A$ belt of wampum is alio given on this occafion, which ferves as a ratification of the peace, and records to the lateft pofterity, by the hieroglyphicks into which the beds are formed, every ftpulated aiticic in the tivaty.

Thefe belts are mace of thells found on the coarts of New England and Virginia, which are fawed out into bcads of an oblong form, about a quarter of an inch long, and round like other beads: Being ftruag on leather

$$
\mathrm{Z}_{2} \text { ftrings, }
$$




\section{( 340$)$}

ftrings, and feveral of them fewed neatly together with fine finewy threads, they then compole what is termed a Belt of Wampum.

The Thells, are generally of two colours, forne white and others violet; but the latter are more highly efteemed than the former. They are held in as much eftimation by the Indians, as gold, filver, or precious ftones are by the Europeans.

The belts are compofed of ten, twelve, or a greater number of ftrings, according to the importance of the affair in agitation or the dignity of the perfon to whom it is prefented. On more trifling occafions, ftrings of thefe beads are prefented by the chiefs to each other, and frequently worn by them about their necks, as a valuable ornament.

\section{$\begin{array}{llllll}\text { C } & \text { H } & \text { A } & \text { P. } & \text { XI. }\end{array}$ \\ Of their G A M E s.}

A S I have beforc obferved, the Indians $\mathcal{L}$ are greatly addiated to gaming, and will even ftake, and lofe with compofure, all the valuables they are poffeffed of. They amufe themfelves at feveral forts of games,

but the them is the Eu The thofe $n$ of a pi tened tc the hai with it three $f$ is fixed of the from a ball, an are not party,

This compan than th mon fo other.

The ground one of combat the cen betwee endeav but 


\section{(34I)}

but the prineipal and inoft efteemed among them is that of the ball, which is not unlike the European game of ternis.

The balls they ufe are rather larger than thofe made ufe of at tennis, and are formed of a piece of decr-fkin; which being moiftened to render it fupple, is ftuffed hard with the hair of the fame creature, and fewed with its finews. The ball-fticks are about three feet long, at the end of which there is fixed a kind of racket, refembling the palm of the hand, and farhoned of thongs cut from a deer-1kin. In thefe they catch the ball, and throw it to a great diftance, if they are not prevented by fome of the oppofite party, who fly to intercept it.

This game is generally played by large companies, that fometimes confift of more than three hundred; and it is not uncommon for different bands to play againft each other.

They begin by fixing two poles in the ground at about fix hundred yards apart, and one of thefe goals belong to each party of the combatants. The ball is thrown up high in the centre of the ground, and in a direct line between the goals; towards which each party endeavours to ftrike it, and which ever fide firft 


\section{$(3+2)$}

firft caufes it to reach their own goal, reckons towards the game.

They are fo excceding dextrous in this manly exercife, that the ball is ufually kept flying in difierent directions by the force of the rackets, without touching the ground during the whole contention; for they are not allowed to catch it with their hands. They run with amazing velocity in purfuit of each other, and when one is on the point of hurling it to a great diftance, an antagonift overtakes him, and by a fudden ftroke dafhes down the ball.

They play with fo much vehemence that they frequently wound each other, and fometimes a bone is broken; but notwithftanding thefe accidents there never appears to be any fpite or wanton exertions of firength to effect them, nor do any difputes ever happen between the parties.

There is another game alfo in ufe among them worthy of remark, and this is the game of the Bowl or Platter. This game is played between two perfons only. Each perfon has fix or eight little bones not unlike a peachftone either in fize o: hape, except that they are quadrangular; two of the fides of which are coloured black, and the others white. Thefe

they thr fall into and mad

Accor or black he that $\mathrm{h}$ ber turn points;

The the lofer pointed village is and at tir

Durin! greatly a fet up a fand cor the fame imprecat fuccefsfu will lofe their cal berty, $\mathrm{n}$ in the 1 than the 


\section{( 343$)$}

they throw up in the air, from whence they fall into a bowl or platter placed underneath, and made to fpin round.

According as thefe bones prefent the white or black fide upwards they reckon the gamc: he that happens to have the greatelt number turn up of a fimilar colour, counts five points; and forty is the game.

The winning party keeps his place, and the lofer yields his to another who is appointed by one of the umpires; for $a$ whole. village is fometimes concerned in the party, and at times one band plays againft another.

During this play the Indians appear to be greatly agitated, and at cvery decifive throw fet up a hideous hout. They make a thoufand contortions, addreffing themfelves at the fame time to the bones, and loading with imprecations the evil fpirits that affift their fuccefsful antagonifts. At this game fome will lofe their apparel, all the moveables of their cabins, and fometimes even their liberty, notwithftanding there are no people in the univerfe more jealous of the latter than the Indians are. 


\section{( 344$)$}

\section{C $\quad \mathrm{H}$ A P. XII.}

Of their Marriage Ceremonies, Ecc.

THE Indians allow of polygamy, and

1 perfons of every rank indulge themfelves in this point. The chiefs in particular have a feraglio which confifts of an uncertain number, ufually from fix to twelve or fourteen. The lower ranks are permitted to take as many as there is a probability of their being able, with the children they may bear, to maintain. It is not uncommon for an Indian to marry two fifters; fometimes, if there happen to be more, the whole number; and notwithftanding this (as it appears to civilized nations) unnatural union, they all live in the greateft harmony.

The younger wives are fubmiffive to the elder; and thofe who have no children, do fuch menial offices for thofe who are fertile, and caufes their fituation to differ but little from a ftate of fervitude. However they perform every injunction with the greateft cheerfulnefs, in hopes of gaining thereby the affection of their hurband, that they in

their $\mathrm{t}$ ing ino attendi

It is though to live them $f$ nate a: by the and by contin of the fented abode tering cafe tl hurba: difples at any libert. they they $\mathrm{h}$ $\mathrm{Th}$ natio amon as the confo their 


\section{( 345$)$}

their turns may have the happinefs of becoining inothers, and be intitled to the refpect attending on that ftate.

It is not uncommon for an Indian., although he takes to himfelf fo many wives, to live in a ftate of continence with many of them for feveral years. Such as are fo fortunate as to $\mathrm{g}$ in the favour of their hufband by their fubmiffive and prudent behaviour, and by that means to Thare in his embraces, continue in their virgin ftate during the whole of their lives, except they happen to be prefented by hin to fome ftranger chief, whofe abode among them will not admit of his entering into a more lafting connection. In this cafe they fubmit to the injunction of their hurband without murmuring, and are not difpleafed at the temporary union. But if at any time it is known that they take this liberty without fir!t receiving his confent, they are punifhed in the fame manner as if they had been guilty of adultery.

This cuftom is more prevalent among the nations which lie in the interior parts, than among thofe that are nearer the fettlements, as the manners of the latter are rendered conformade in fome points to thofe of the Europeans, 


\section{IMAGE EVALUATION TEST TARGET (MT-3)}
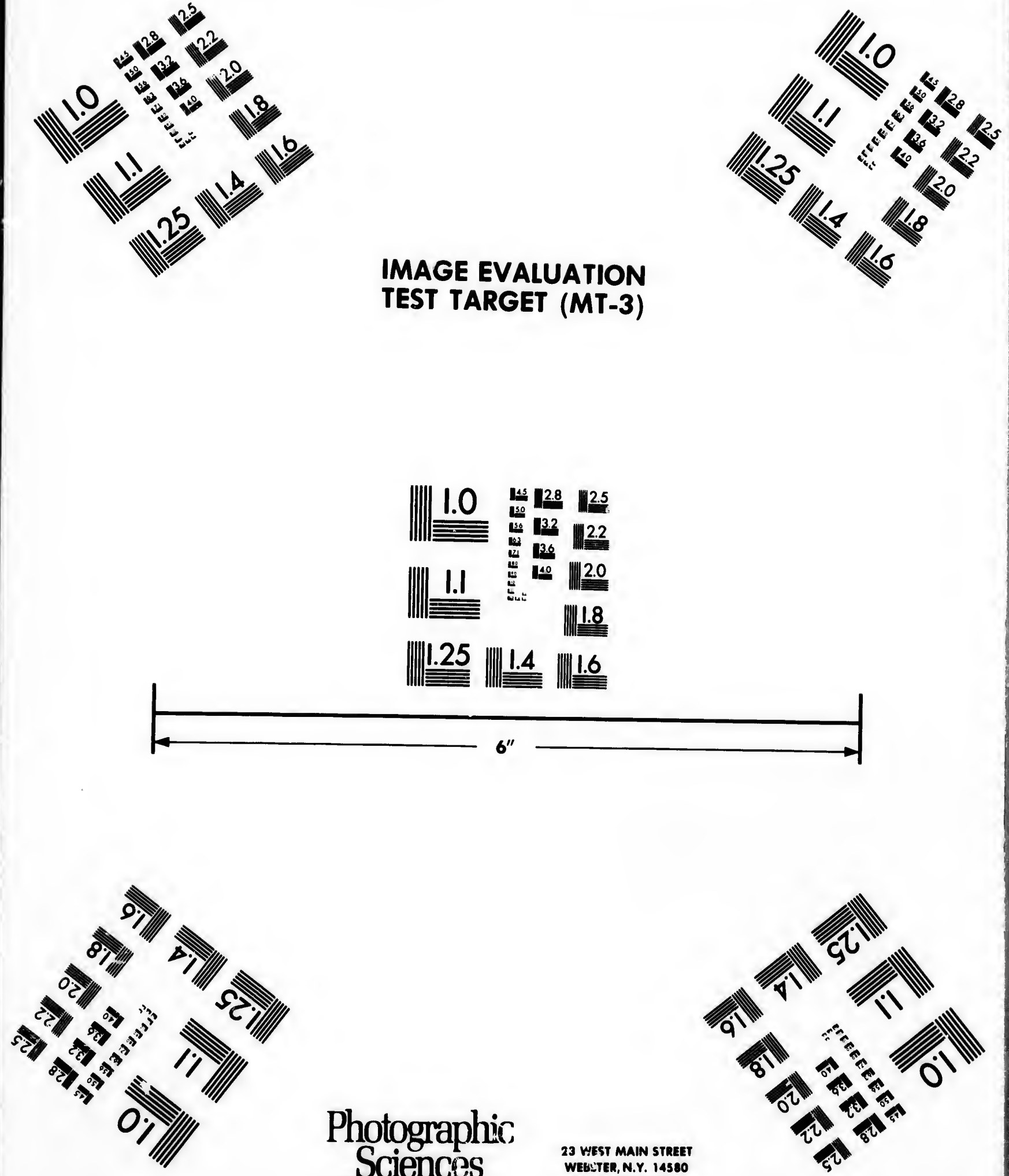

Photographic Sciences Corporaticn

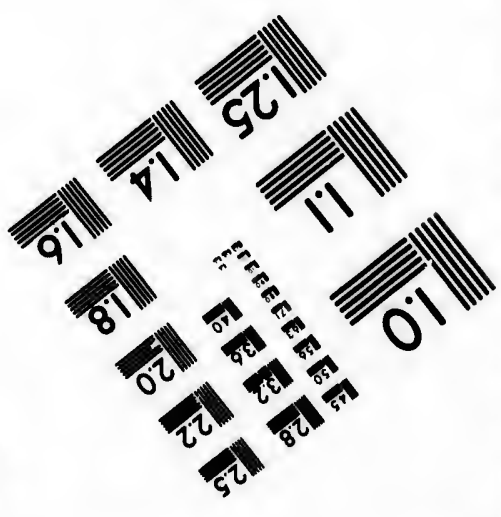





\section{$(346)$}

Europeans, by the intercourie they hold with them.

The Indian nations differ but little from each other in their marriage ceremonies, and lefs in the manner of their divorces. The tribes that inhabit the borders of Canada, make ufe of the following cuftom.

When a young Indian has fixed his inclinations on one of the other fex, he endeavours to gain her confent, and if he fucceeds, it is never known that her parents ever obfruct their union. When every preliminary is agreed on, and the day appointed, the friends and acquaintance of both parties affemble at the houfe or tent of the oldeft relation of the bridegroom, where a fecift is prepared on the occafion.

The company who meet to affift at the felival are fometimes very numerous; they dance, they fing, and enter into eviry other diverfion ufually made ufe of on any of their public rejoicings. When thefe are finimed, all thofe who attend merely ont of ceremony depart, and the bridezroom anc bride are left alone with three or four of the neareft and oldeft relations of either fide; thofe of the bridegroom being men, thoie of the bride, women. 


\section{( 347 )}

Prefently the bride, attcnded by thefe ferv friends, having withdrawn herfelf for the purpofe, appears at one of the doors of the houfe, and is led to the bridegroom, who ftands ready to receive her. Having now taken their fation on a mat placed in the centre of the room, they lay hold of the extremities of a wand about four feet long, by which they continue feparated, whilf the old men pronounce fome fhort harangucs fuitable to the occafion.

The married couple after this make a public declaration of the love and regard they entertain for each other, and ftill holding the rod between them, dance and fing. When they have finifhed this part of the ceremony, they break the rod into as many pieces as there are witneffes prefent, who each take a piece, and preferve it with great care.

The bride is then re-conducted out of the door at which the entered, where her young companions wait to attend her to her father's houfe; there the bridegroom is obligcd to feek her, and the marriage is confummated. Very often the wife remains at her father's houfe till the has a child, when the packs up her apparel which is all the fortune 


\section{( 348 )}

The is generally poffeffed of, and accompanies her liurband to his habitation.

When froin any dinlike a feparation takes place; for they are feldom known to quarrel, they generally give their friends a few days notice of their intentions, and fometimes offer rea?ons to juftify their conduct. The witneffes who were prefent at the marriage, meet on the day requefted at the houfe of the couple that are about to feparate, and bringing with them the pieces of rod which they had received at their nuptials, throw them into the fire in the prefence of all the parties.

This is the whole of the ceremony required, and the feparation is carried on without any murmurings or ill-will between the couple or their relations, and after a few months they are at liberty to marry again.

When a marriage is thus diffolved, the children which have been produced from it, are equally divided between them; and as children are efteemed a treafure by the Indians, if the number happens to be odd, the woman is allowed to take the better half.

Though this cuftom feems to encourage ficklenefs and frequent feparations, yet there are many of the Indians who have but one wife, 


\section{( 349 )}

wife, and enjoy with her a ftate of connubial happinefs not to be exceeded in more refined focieties. There are alfo not a few inftances of women preferving an inviolablc attachment to their hurbands, except in the cafes before-mentioned, which are not confidered as either a violation of their chaftity or fidelity.

Although I have faid that the Indian nations differ very little from each other in their marriage ceremonies, there are fone exciptions. The Naudoweffies have a fingular method of celebrating their marriages, which feems to bear no refemblance to thofe made ufe of by any other nation I paffed through. When one of their young men has fixed on a young woman he approves of, he difcovers his paffion to her parents, who give him an invitation to come and live with them in their tent.

He accordingly accepts the offer, and by fo doing engages to refide in it for a whole year, in the character of a menial fervant. During this time he hunts, and brings all the game he kills to the family; by which means the father has an opportunity of feeing whether he is able to provide for the fupport of his daughter and the children that might be 


\section{( 350$)$}

the confequence of their union. This however is only done whilf they are young men, and for their firft wife, and not repeated like Jacob's fervitudes.

When this period is expired, the marriage is folemnized after the culom of the country, in the following manner. Three or four of the oldeft male relations of the bridegroom, an 1 as many of the bride's, accompany the young couple from their refpedive tents to an open part in the centre of the camp.

The chiefs and warriors being here affembled to receive them; a party of the latter are drawn up in two ranks on each fide of the bride and bridegroom immediately on their arrival. The principal chief then acquaints the whole affembly with the defign of their meeting, and tells them that the couple before them, méntioning at the fame time their names, are come to avow publicly their intentions of living together as man and wife. He then anks the two young people alternately, whether they defire that the union might take place. Having declared with an audible voice that they do fo, the warriors fix their arrows, and difcharge them over

$\mathrm{Tl}$

no

fav

$\mathrm{mc}$

the

are

ob

eq

na

fe

ac

th 


\section{( $35 \mathrm{I})$}

over the heads of the married pair; this done, the chief pronounces them man and wife.

The bridegroom then turns round, and bending his body, takes his wife on his back, in which manner he carries her amidft the acclamations of the fpectators to his tent. This ceremony is fucceeded by the mott plentiful feaft the new married man can afford, and fongs and dances, according to the ufual curtom, conclucie the feftival.

Divorces happen fo feldom among the Naudoweflies, that I hid not an cpportunity of learning how they are accomplifhed.

Adultery is eftecmed by them a heinous crime, and punimed with the greatent rigour. The hurband in thefe cafes bites off the wife's nofe, and a feparation inftantly enfues. I faw an inftance wherein this mode of punithment was inflicted, whi'ft I remained among them. The children, when this happens, are difributed according to the ufual cuftom obferved by other nations, that is, they are equally divided.

Among the Indian as well as European nations, there are many that devote themfelves to pleafure, and notwithftanding the accounts given by fome modern writers of the frigidity of an Indian confitution, bc- 


\section{( 352$)$}

come the zcalous votaries of Venus. The young warriors that are thus difpofed, feldom want opportunities for gratifying their paflions; and as the mode ufually followed on thefe occafions is rather fingular, I thall defcribe it.

When one of thefe young debauchees imamagines from the behaviour of the perfon he has chofen for his miftrefs, that he shall not meet with any great obfruction to his fuit from her, he purfues the following plan.

It has been already obferved, that the Indians acknowledge no fuperiority, nor have they any ideas of fubordination, except in the neceffary regulations of their war or hunting parties; they confequently live near$l y$ in a ftate of equality purfuant to the firft principles of nature. The lover therefore is not apprehenfive of any check or controul in the accomplifhment of his purpores if he can find a convenient opportunity for compleating them.

As the Indians are alfo under no apprehenfion of robbers, or fecret enemies, they leave the doors of their tents or huts unfaftened during the night, as : well as in the day. Two or threc hours after fun-fet, the flaves

he

com

has

take

that

and

to $\mathrm{r}$

D

muc

and

ufus

out

men

fion 


\section{( 353 )}

or old peopli cover over the fire, that is generally burning in the midft of their apartment, with arhes, and retire to their repofe.

Whilft darknefs thus prevails, and all is quiet, one of thefe fons of pleafure, wrapped up clofely in his blanket to prevent his being known, will fometimes enter the apartment of his intens!ed miftrefs. Having firt lighted at the fmothered fire a finall fplinter of wood, which anfwes the purpofe of a match, he approaches the place where the repofes, and gently pulling away the covering from her head, jogs her till the wakes. If the then rifes up, and blows out the light, he needs no further confirmation that his company is not difagreeable; but if, after he has difcovered himfelf the hides her head, and takes no notice of him, he might reft affured that any furiher folicitations will prove vain, and that it is neceffary for him immediately to retire.

During his ftay he conceals the light as much as poffible in the hollow of his hands, and as the tents or rooms of the Indians are ufually large and capacious, he efcapes without detection. It is faid that the young women who admit their lovers on thefe occafions, take great care, by an immediate apA a

- plication 


\section{( 354$)$}

plication to herbs, with the potent efficacy of which they are well acquainted, to prevent the effects of thefe illicit amours from becoming vifible; for Thould the natural confequences enfue, they muft for ever remain unmarried.

The children of the Indians are always diftinguilhed by the name of the mother; and if a woman marries feveral hurbands, and has iffue by each of them, they are all called after her. The reafon they give for this is, that as their offspring are indebted to the father for their fouls, the invifible part of their effence, and to the mother for their corporeal and apparenc part, it is more rational that they thould be diftinguifhed by the name of the latter, from whom they indubitably derive their being, than by that of the father, to which a doubt might fometimes arife whether they are juftly intitled.

There are fome ceremonies made ufe of by the Indians at the impofition of the name, and it is confidered by them as a matter of great importance; but what thefe are I could never learn, through the fecrecy obferved on the occafion. I only know that it is ufually given when the children have paffed the fate of infancy.

Nothing

lies

at

nali

hun

nen

to $\mathrm{P}$ to 


\section{( 355$)$}

Nothing can exceed the tendernefs: Shown by them to their offspring; and a perfon cannot recommend himfelf to their favour by any method more certain, than by paying fome attention to the younger branches of their families. I can impute in fome meafure, to the prefents I made to the children of the chiefs of the Naudoweffies, the horpitable reception I met with when among them.

There is fome difficulty attends an explanation of the manner in which the Indians diftinguifh themfelves from each other. Befides the name of the animal by which every nation and tribe is denominated, there are others that are perfonal, and which the children receive from their mother.

The chiefs are alfo diftinguifhed by a name that has either fome reference to their abilities, or to the hieroglyphick of their families; " and thefe are acquired after they arrive at the age of manhood. Such as have fignalized themfelves either in their war or hunting parties, or are poffeffed of fome eminent qualification, receive a name that ferves to perpetuate the fame of thefe actions, or to make their abilities confpicuous.

$$
\text { A a } 2
$$

Thus 


\section{$\left(35^{6}\right)$}

Thus the great warrior of the Naudoweffies was named Ottahtongoomlinhcah, that is, the Great Father of Snakes: ottah being in Englin father, tongoum great, and lifhcah a fnake. Another chief was called Honalupawjatin, which means a fwift runner over the mountains, And when they adopted me a chief among them, they named me Shebaygo, which fignifies a writer, or a perfon that is curious in making hieroglyphicks, as they law me often writing.

\section{H A P. XIII.}

Of their RE LIG I O N.

$T$ is very difficult to attain a perfect 1 knowledge of the religious principles of the Indians. Their ceremonies and doctrines have been fo often ridiculed by the Europeans, that they endeavour to conceal them; and if, after the greateft intimacy, you defire any of them to explain to you their fyftem of religion, to prevent your ridicule they intermix with it many of the tenets they have received from the French miffionaries, fo that it is at laft rendered an unintelligible jargon, and not to be depended upon.

Such 


\section{( 357$)$}

Such as I could difcover among the Naudoweffies, for they alío were very referved in this point, I thall give my readers, without paying any attention to the accounts of others. As the religion of that people from their fituation appears to be totally unadulterated with the fuperftitions of the church of Rome, we thall be able to gain from their religious cuftoms a more perfect idea of the original tenets and ceremonies of the Indians in general, than from thofe of any nations that approach nearer to the fettlements.

It is certain that they acknowledge one Supreme Being or Giver of Life, who prefides over all things. The Chipéways call this being Manitou or Kitchi-Manitou; the Naudoweffies, Wakon or Tongo-Wakon, that is, the Great Spirit; and they look up to him "as the fource of good, from whom no evil can proceed. They alfo believe in a bad fpirit, to whom they afcribe great power, and fuppofe that through his means all the evils which befall mankind are inflicted. To him therefore do they pray in their diftreffes, begging that he would either avert their troubles, or moderate them when they are no longer avoidable.

They. 


\section{( $\left.35^{8}\right)$}

They fay that the Great Spirit, who is infinitely good, neither withes or is able to do any mifchief to mankind, but on the contrary, that he howers down on them all the bleffings they deferve; whereas the evil fojrit is continually employed in contriving how he may punifh the human race; and to do which he is not only poffeffed of the will, but of the power.

They hold alfo that there are good fpirits of a leffer degree, who have ther particular departments, in which they are conftantly contributing to the happinefs of mortals. Thefe they fuppofe to prefide over all the extraordinary productions of nature, fuch as thofe lakes, rivers or mountains that are of an uncommon magnitude; and likewife the beafts, birds; fines, and even vegefables or ftones that exceed the reft of their fpecies in fise or fingularity. To all of thefe they pay fome kind of adoration. Thus when they arrive on the borders of Lake Superior; on the banks of the Miffiflippi, or any other great body of water, they prefent to the Spirit who refides there fome kind of offering as the prince of the Winnebagoes did when he attended me to the Falls of St. Anthony.

tation be 0 more

Of lative they howe will here, nexec ence.

$\mathrm{Th}$ to a ways a pe abou whic pain finit; in $r$ tific: degr 


\section{( 359 )}

But at the fame time I fancy that the ideas they annex to the word fpirit, is very different from the conceptions more enlightened nations entertain of it. They appear to fahion to themfelves corporeal reprefentations of their gods, and believe them to be of a human form, though of a nature more excellent than man.

Of the fame kind are their fentiments relative to a futurity. They doubt not but they thall exift in fome future ftate, they however fancy that their employments there will be fimilar to thofe they are engaged in here, without the labour and difficulty annexed to them in this period of their exiftence.

They confequently expect to be tranflated to a delightful country, where they thatl always haye a clear unclouded $\mathrm{Ay}$, and enjoy a perpetual fpring; where the forefts will abound with game, and the lakes with fifh; which might be taken without requiring a painful exertion of Akill, or a laborious purfiit ; in thort, that they thall live for ever in regions of plenty, and enjoy every gratification they delight in here, in a greater degree. 


\section{( 360$)$}

To intelle \&ual pleafures they are ftrangers; nor are thefe included in their fcheme of happinefs. But they expect that even thefe animal pleafures will be proportioned and diftributed according to their merit; the fkilful hunter, the bold and fuccefsful warrior will be entitled to a greater thare than thofe who through indolence or want of fikill cannot boaft of any fuperiority over the common herd.

The priefts of the Indians are at the fame time their phyficians, and their conjurors; whilf they heal their wounds or cure their difeafes, they interpret their dreams, give them protective charms, and fatisfy that defire which is prevalent among them of fearching into fu urity.

How well they execute the latter part of their profeffonal engagements, and the methods they make ufe of on forne of thefe occafions, I have already thewn in the exertions of the prieft of the Killiftinoes, who Was furtunate enough to fucceed in his extraordinary at tempt near Lake Superior. They frequently are fuccefsful likewife in adminiftering the falubrious herbs they have acquired a knowledge of ; but that the ceremonies they make ufe of during the adminiftration

that

his

nan

ed

off

the

to $\mathrm{i}$

do,

tal 


\section{$\left(3^{61}\right)$}

niftration of them contribute to their fuccefs, I hall not take upon me to affert.

When any of the people are ill, the perfon who is invefted with this triple character of doctor, prieft, and magician, fits by the patient day and night, rattling in his ears a goad-hell filled with dry beans; called a Chichicous, and making an difagreeable noife that cannot well be defcribed.

This uncouth harmony one would imagine fhould difturb the fick perfon, and prevent the good effects of the doctor's prefcription; but on the contrary they believe that the method made ufe of contributes to his recovery, by diverting from his malignant purpofes the evil fpirit who has inflicted the diforder; or at leaft that it will take: off his attention, fo that he fhall not increafe the malady. This they are credulous enough to imagine he is conftantly on the watch to do, and would carry his inveteracy to a fatal length if they did not thus charm him.

I could not difcover that they make ufe of any other religious ceremonies than thofe I have defcribed; indeed on the appearance of the new moon they dance and fing, but it is not evident that they pay that planct any adorations; they only feem to rejoice at 


\section{$\left({ }^{3} 62\right)$}

the return of a luminary that makes the night cheerful, and which ferves to light them on their way when they travel during the abfence of the fun.

Notwithfanding $\mathbf{M r}$, Adair has afferted that the nations among whom he refided, obferve with very little variation all the rites appointed by the Mofaic Law, I own I could never difcover among thofe tribes that lie but a few degrees to the north-weft, the leaft traces of the Jewifh religion, except it be admitted that one particular female cuftom and their divifion into tribes, carry with them proof fufficient to eftablifh this affertion.

The Jefuits and French miffionaries have alfo pretended that the Indians had, when they firft travelled into America, fome notions, though thefe were dark and confufed, of the chriftian inftitution; that they have been greatly agitated at the fight of a crofs, and given proofs by the impreffions made on them that they were not entirely unacquaitited with the facred myfteries of chriftianity. I need not fay that the fe are too glaring abfurdities to be credited, and could only receive their exiftence from the zeal of thofe fathers, who endeavoured at once to

moft

not

tions,

into

nerat

wond

before

perfor

extral

whet

charg

the is

not I

Tl

is ap

of $n$

hurri

bein

are a

frons 


\section{$\left(3_{6}{ }_{3}\right)$}

give the public a better opinion of the fuc cers of their miffions, and to add fupport to the caufe they were engaged in.

The Indians appear to be in their religious principles rude and uninftructed. The doctrines they hold are few and fimple, and fuch as have been generally impreffed on the human mind, by fome means or other, in the moft ignorant ages. They however have not deviated, as many other uncivilized nations, and too many civilized ones have done, into idolatrous modes of worfhip; they venerate indeed and make offerings to the wonderful parts of the creation; as I have before obferved, but whether thefe rites are performed on account of the impreffion fuch extraordinary appearances make on them, or whether they confider them as the peculiat: charge, or the ufual places of refidence of the invifible fpirits they acknowledge, I can not pofitively determine.

The human mind in its uncultivated fate is apt to arcribe the extraordinary occurrences of nature, fuch as earthquakes, thunder, or hurricanes, to the interpofition of unfeen beings; the troubles and difafters alfo that are annexed to a favage life, the apprehen- fions attendant on a precarious fubfiftence, 


\section{( 364 )}

and thofe numberlefs inconveniencies which man in his improved ftate has foùnd means to remedy, are fuppofed to proceed from the interpofition of evil fpirits; the favage confequently lives in continual apprehenfions. of their unkind attacks, and to avert them has recourfe to clarms, to the fantaftic ceremonies of his prieft, or to the powerful influence of his Manitous. Fear has of courfe a greater mare in his devotions than gratitude, and he pays more attention to deprecating the wrath of the evil than to fecuring the favour of the good beings.

The Indians, however, entertain thefe abfurdities in common with thofe of every part of the globe who have not been illumined by that religion which only can difperfe the clouds of fuperftition and ignorance, and they are as free from error as a people can be that has not been favoured with its inAtructive doctrines. 


\section{$(365)$}

\section{H A P. XIV. \\ Of their DISEASEs; Ec.}

7 HE Indians in general are healthy, 1 and fubject but to few difeares, many of thofe that afflict civilized nations, and are the immediate confequences of luxury or floth, being not known among them; however the hardinips and fatigues which they endure in hunting or war, the inclemency of the feafons to which they are continually expofed, but above all the extremes of hunger, and that voracioufnefs their long excurfions confequently fubjoct them to, cannot fail of impairing the conftitution, and bringing on diforders.

Pains and weakneffes in the ftomach and breaft are fonetimes the refult of their long fafting, and confumptions of the exceffive fatigue and violent exercifes they expofe themfelves to from their infancy, before they. have frength fufficient to fupport them. But the diforder to which they are moft fubject, is the pleurify; for the removal of which, they apply their grand remedy and prefervative 


\section{( 366 )}

tive againft the generality of their complaints, fweating.

The manner in which they conftruct their ftoves for this purpofe is as follows: They fix feveral fmall poles in the ground, the tops of which they twift together to form a rotunda : this frame they cover with Akins or blankets; and they lay them on with fo much nicety, that the air is kept from entering through any crevice; a finall fpace being only left fufficient to creep in at, which is immediately after clofed. In the middle of this confined building they place red hot ftones, on which they pour water till a fteam arifes that produces a great degree of heat.

This caufes an inftantaneous perfpiration, which they increafe as they pleafe. Having continued in it for fome time, they immediately haften to the neareft ftream, and plunge into the water; and after bathing therein for about haif a minute, they put on their cloaths, fit down and fmoak with great compofure, thoroughly perfuaded that the remedy will prove efficacious. They often make ufe of this fudoriferous method to refrefh themfelves, or to prepare their minds for the management of any bufiners

rem mak ed 0 fectl they way tiou wou 'fuffi V

fimp

brui

wit!

of $n$ cure tro tha pro pro rep fpli fica that 


\section{$\left(3^{67}\right)$}

that requires uncommon deliberation and fagacity.

They are likewife afflicted with the dropfy and paralytic complaints; which however are but yery feldom known among them. As a remedy for thefe as well as for fevers they make ufe of lotions and decoctions, compofed of herbs, which the phyficians know perfectly well how to compound and apply. But they never truft to medicines alone; they always have recourfe likewife to fome fuperfitious ceremonies, without which their patients would not think the phyfical preparations fufficiently powerful.

With equal judgment they make ufe of fimples for the cure of wounds, fractures, or bruifes; and are able to extract by thefe, without incifion, fplinters, iron, or any fort of matter by which the wound is caufed. In cures of this kind they are extremely dextrous, and complete them in much lefs time than might be expected from their mode of proceeding.

With the lkin of a fnake, which thofe reptiles annually thed, they will alfo extract fplinters. It is amazing to fee the fudden efficacy of this application, notwithftanding there 


\section{( 368$)$}

there does not appear to be the leaft moifture remaining in it.

It has long been a fubject of difpute, on what continent the venereal difeafe firft received its deftructive power. This dreadful malady is fuppofed to have originated in America, but the litery conteft ftill remains undecided; to give fome elucidation to it I thall remark, that as I could not difcover the leaft traces among the Naudoweffies with whom I refided fo lung, and was alfo informed that it was yet unknown among the more weftern nations, I think I may venture to pronounce that it had not its origin in North America. Thofe nations that have any communication witi the Europeans or the fouthern tribes are greatly affliced with it; but they have all of them acquired a knowledge of fuch certain and expeditious remedies; that the communication is not attended with any dangerous confequences.

Soon after I fet out on my travels, one of the traders whom I accompanied, complained of a violent gonorrhoea with all its alarming fymptoms : this increafed to fuch a degree; that by the time we had reached the sown of the Winnebagoes, he was unable to travel, Having made his complaint known to one of

the ch uneafy ing his to pur time be The prepar the roo knowr plenty ufe of recove to pres ture fr radical If $\mathrm{f}$ of hea in thei affecte merce flint, point $t$ a lanc inftrun fubstar

The ill, w rejects 


\section{$(-369)$}

the chiefs of that tribe, he told him not to be uneafy, for he would engage that by following his advice, he thould be able in a few days to purfue his journcy, and in a little longer time be entirely free from his diforder.

The chief had no fooner faid this than he prepared for him a decoction of the bark of the roots of the prickly arh, a tree farccly known in England, but which grows in great plenty throughout North America; by the ufe of which, in a few days he was greatly recovered, and having received dirckions how to prepare it, in a fortnight after his departure from this place perceived that he was radically cured.

If from excelfive cxcrcife, or the cxtremes of heat or cold, they are affected with pains in their limbs or joints, they fearify the parts affected. Thofe nations, who have no coinmerce with Europeans do this with a Marp flint, and it is furprizing to fec to how fine a point the have the dexterity to bring them; a lancet can fcarcely exceed in fharynefs the infruments they make of this unmalleable fubftance.

They never can be convinced a perfon is ill, whilit he has an appetite; but when he rejects all kind of nourifument, they confider

B b the 


\section{( 370$)$}

the difeafe as dangerous, and pay great attention to it. And during the continuance of the diforder, the phyfician refufes his patient no fort of food that he is defirous of.

Their doetors are not only fuppofed to be fkillcd in the phyfical treatment of difeafes, but the common people believe that by the ceremony of the chichicoue ufually made ufe of, as before defcribed, they are able to gain intelligence from the fpirits of the caufe of the complaints with which they are afflicted, and are thereby the better enabled to find remedies for them. 'They difcover fomething fupernatural in all their difeafes, and the phyfic adminiftered muft invariably be aided by thefe fuperftitions.

Sometimes a fick perfon fancies that his diforder arifes from witcheraft; in this cafe the phyfician or juggler is confulted, who after the ufual preparations gives his opinion on the ftate of the difeafe, and frequently finds fome means for his cure. But notwith. ftanding the Indian phyficians always annex thefe fuperftitions ceremonies to their prefcriptions, it is very certain, as I tave already obferved, that they exercife their art by principles which are founded on the knowledge of fimples, and on experience which

they

their

T

a pe

the 1

great

of $n$

dant

equa

In

of $n$

Engl

laboi

affift:

ed.

or th

pecti

to he

$\mathrm{Ar}$ by, $h$ and $\epsilon$

Bein

circu

infor

fee tl

the $\mathrm{c}$

$\mathrm{Tl}$

wife 


\section{$(37 \mathrm{r})$}

they acquire by an indefatigable attention to their operations.

The following itory, which I received from a perfon of undoubted credit, proves that the Indians are not only able to reafon with great acutenefs on the caufes and fymptoms of many of the diforders which are attendant on human nature, but to apply with equal judgment proper remedies.

In Penobfcot, a fettlement in the province of Main, in the north-eaft parts of New England, the wife of a foldier was taken in labour, and notwithftanding every neccflary affiftance was given her, could not be delivered. In this fituation the remained for two or three days, the perfons around her expecting that the next pang would put an end to her exiftence.

An Indian woman, who accidentally paffed by, heard the groans of the unhappy fufferer, and enquired from whence they proceeded. Being made acquainted with the défperate circumftances attending the cafe, the toid the informant, that if the might be permitted to fee the perfon, the did not doubt but that the could be of great fervice to her.

The furgeon that attended, and the midwife who was then prefent, having given up $\mathrm{B}$ b 2 every 


\section{( 372$)$}

every hope of preferving their patient, the Indian woman was allowed to make ufe of any methods the thought proper. She accordingly took a handkerchief, and bound it tight over the nofe and mouth of the woman: this immediately brought on a fuffocation; and from the ftruggles that confequently enfued the was in a few feconds delivered. The moment this was atchieved, and time enough to prevent any fatal effect, the handkerchief was taken off. The long fuffering patient thus happily relieved from her pains, foon after perfectly recovered, to the aftonimment of all thofe who had been witnefs to her defperate fituation.

The reafon given by the Indian for this hazardous method of proceeding was, that defperate diforders require defperate remedies; that as the obferved the exertions of nature were not fufficiently forcible to effect the defired ronfequence, fhe thought it neceffary to augment their force, which could only be done by fome mode that was violent in the extreme.

of $t b$

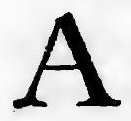

fame

the fil impor many nation is pro mains thore. fure.

If

a kia clude. for $t$ think friend tion thofe eulog

C $\mathrm{H} A \mathrm{~A}$. 


\section{( 373$)$}

\section{H A P, X XV.}

Of the Manner in which they treat their DE A D.

A $\mathrm{N}$ Indian meets death when it apA proaches him in his hut, with the fame refulution he has often faced him in the field. His indifference relative to this important article, which is the fource of fo many apprehenfions to almoft every other nation, is truly admirable. When his fate is pronounced by the phyfician, and it remains no longer uncertain, he harangues thof. about him with the greateft compofure.

If he is a chief and has a family, he makes a kind of funeral oration, which he concludes by giving to his children fuch advice for the regulation of their conduct as he thinks neceffary. He then takes leave of his friends, and iffues out orders for the preparation of a feaft, which is defigned to regale thofe of his tribe that come to pronounce his eulogium. 


\section{( 374 )}

After the breath is departed, the body is dreffed in the fame attire it ufually wore whilft living, his face is painted, and he is feated in an erect pofture on a mat or $\mathrm{kin}$ pliced in the middle of the hut, with his weapons by his fide. His relations being feated round, each hangues in turn the deceafed; and if he has been a great warrior recounts his heroic actions nearly to the following purport; which in the Indian language is extremely poetical and pleafing.

"You ftill fit among us, Brother, your "perfon retains its ufual refemblance, and " continues fimilar to ours, without any vi-" "fible deficiency, except that it has loft the "power of action. But whither is "that " breath flown, which a few ho:rrs ago rent "up fmoke to the Great Spirit? Why are " thofe lips fllent, that lately delivered to us " expreffive and pleafing language? why are " thofe feet motionlers, that a fhort time ago "were fleeter than the deer on yonder moun"tains? why ufelefs hang thofe arms that " could climb the talleft tree, or draw the " toughieft bow? Alas! every part of that " frame which we lately beheld with admira" tion and wonder, is now become as inani"mate as it was three hundred winters ago.

Wer

" thou

" name "foul "rits, "befor

"perpe "thee. "s thee "to the "powe "lie ne "prey

"of the "thofe "befor "thy f] "be re "arrive In A does:ev parted they ha the plas tribe, a feafon, it on a on the 


\section{( 375$)$}

« We will not, however, bemoan thee as if " thou waft for ever loft to us, or that thy "name would be buried in oblivion; thy " foul yet lives in' the great Country of Spi"rits, with thofe of thy nation that are gone "before thee; though we are left behind to "perpetuate thy fame, we thall one day join "thee. Actuated by the refpect we bore "thee whilf living, we now come to tender " to thee the laft act of kindnefs it is in our "power to beftow: that thy body might not "lie neglected on the plain, and become a "prey to the beafts of the field, or the fowls "of the air, we will take care to lay it with "thofe of thy predeceffors who are gone " before thee, hoping at the fame time, that "thy fpirit will feed with their fpirits, and ", be ready to receive ours, when we alfo thall "arrive at the great Country of Souls."

In Ahort fpeeches fomewhat finilar to this does every chief fpeak the praifes of his departed friend: When they have fo done, if they happen to be at a great diftance from the place of interment appropriated to their tribe, and the perfon dies during the winter feafon, they wrap the body in flins, and lay it on a high ftage built for this purpofe, or on the branches of a large tree, till the fpring

arrives. 


\section{$(376)$}

arrives. They then, after the manner dercribed in my Journal, carry it; together with all thofe belonging to the fume nation, to the general burial-place, where it is interred with fome other ceremonies that I could not difcover.

When the Naudoweffies brought their dead for interment to the great cave, I attempted to get an infight into the remaining burial rites; but whether it was on account of the ftench which arofe from fo many bodies, the weather being then hot, or whether they chofe to keep this part of their cuftoms fecret from me, I could not difcover; I found, however, that they confidered my curiofity as ill-timed, and therefore I withdrew.

After the interment, the band to which the perfon belongs, take care to fix near the place fuch hieroglypinicks as thall thew to future ages his merit and accomplifhinents. If any of thefe people die in the fummer at a diftance from the burying-ground, and they find it impofible to remove the body before it putrefies, they burn the flefh from the bones, and preferving the latter, bury them in the manner defcribed.

As tl

deceafe mannes did on huntin conten not en provide their $b$ weapo: they d occaipo thofe ufually ftuffs : of, dor ing th $\therefore$ Tho his 10 and a: ufe of hut or terval permi $\mathrm{On}$ amon from tions 


\section{( 377$)$}

As the Indians believe that the fouls of the deceafed employ themfelves in the fame manner in the country of fpirits, as they did on earth, that they acquire their food by hunting, and have there, allo, enemies to contend with, they takc care that they do not enter thefe regions defencelefs and unprovided: they confequently bury with them their bows, their arrows, and all the other weapons wed either in hunting or war. "As they doubt not but they will likewife have occaison both for the neceffaries of life and thofe things they eneem as ornaments, they ufually depofit in their tombs fuch fkins or ftuffs as they commonly made their garments of, domeftic utenfils, and paint for ornamenting their per.isins.

$\therefore$ The near relations of the deceafed lament his lofs with an appearance of great forrow and anguifh; they weep and howl and make ufe of many contortions, as they fit in the hut or tent arourd the body, when the intervals between the praifes of the chiefs will permit.

One formality in mourning for the dead among the Naudoweffics is very different from any mode $I$ obferved in the other nations through which I paffed. The men, to

Mhow 


\section{( 378$)$}

Ahow how great their forrow is, pierce the fleth of their arms, above the elbows, with arrows; the fcars of which I conld perceive on thofe of every rank, in a greater or lefs degree; and the women cut and gath their legs with Marp broken flints, till the blood flows very plentifully. :

Whilft I remained among them, a couple whofe tent was adjacent to mine, loft a fon of about four years of age. The parents were fo much affected at the death of their favourite child, that they purfued the ufual teftimonies of grief with fuch uncommon rigour, as through the weight of forrow and lofs of blood, to occafion the death of the father. The woman, who had hitherto bein inconfolable, no fooner faw her hufband ex. pire, than the dried up her tears, and appeared cheerful and refigned.

As I knew not how to account for fo extraordinary a tranfition, I took an opportunity to ank her the reafon of it; telling her at the fame time, that I thould have imagined the lofs of her hufband would rather have occafioned an increafe of grief, than fuch a fudden diminution of it.

She informed me, that as the child was fo young when it died, and unable to fupport

itfelf in

her hufb: fituation fooner di the fame with the hunter, a tifully fo mourn. reafon to whom the and prot the had tified, wl them:

Expref derners, a honour $t$ preffion people $t$ not a litt hitherto other $\operatorname{tr}^{2}$ want of

$\mathrm{Her} \mathrm{fi}$ vourable convince parent $f$ itfelf 


\section{( 379$)$}

itfelf in the country of firits, both the and her hufband had been apprehenfive that its fituation would be far from happy; but no fooner did The behold its father depart for the fame place, who not only loved the child with the tendereft affection, but was a good hunter, and would be able to provicie plentifully for its fupport, than the ceafed to mourn. She added, that the now faw no reafon to continue her tears; as the child on whom the doated was happy under the care and protection of a fond father, and that the had only one winh that remained ungratified, which was that of being herfelf with them:

Expreffions fo replete with unaffected tendernefs, and fentiments that would have done honour to a Roman matron, made an impreffion on my mind greatly in favour of the people to which the belonged, and tended not a little to counteract the prejudices. I had hitherto entertained, in common with every other traveller, of Indian infenfibility and want of parental tenderners.

Her fubfequent conduct confirmed the favourable opinion I had juft inbibed; and convinced me, that notwithftanding this apparent fufpenfion of her grief, fome particles 


\section{$(380)$}

cles of that relustance to be feparated from a beloved relation which is implanted either by nature or cuftom in every human heart, ftill lurked in hers. I obferved that the went almoft every evening to the foot of the tree, on a branch of which the bodies of her hurband and child were laid, and after cutting off a lock of her hair, and throwing it on the ground, in a plaintive melancholy fong bemoaned its fate. A recapitulation of the actions he might have performed, had his life been fpared appeared to be her favourite theme; and whilt the foretold the fame that would have attended an imitation of his father's virtucs, her grief feemed to be fufpended:-

"If thou hadffcontinued with us, my dear "Son, would fine cry, how well would the "bow have become thy hand, and how fa" tal would thy arrows have proved to the " enemics of our bands! Thou wouldnt often " have drank their blood, and eaten their "fleth, and numerous flaves would have re"warded thy toils. With a nervous arm "wouldf thou have feized the wounded "buffalo, or have combated the fury of the " enraged bear. Thou wouldit have over" taken the flying elk, and have kept pace

" on th "deer. "perfo " age h " had i "plifh untuto and $\mathrm{fr}$ part of The the 0 mourn they $\mathrm{C}$ and $\mathrm{fi}$ clofely every for $\mathrm{fe}$ ons th fevera Naud lives an in fo as woul fpect if it and $t$ 


\section{( $38 \mathrm{r})$}

"on the mountain's brow with the ficeteft " deer. What feats mighteft thou not have "performed, hadft thou ftaid among us till "age had given thee ftrength, and thy father " had inftructed thee in every Indian accom" plifhment!" In terms like thefe did this untutored favage bewail the lofs of her fon, and frequently would the pafs the greatert part of the night in the affectionate employ.

The Indians in general are very firict in the obfervance of their law's relative to mourning for their dead. In fome nations they cut off their hair, blacken their faces, and fit in an erect pofture with their heads clofely covered, and depriving themfelves of every pleafure. This feverity is continued for feveral months, and with fome relixations the appearance is fometimes kept up for feveral years. I was told that when the Naudoweffies recolle tcd any incidents of the lives of their deceafed relations, even after an interval of ten years, they would how! fo as to be heard at a great diftance. They would fometimes continue this proof of refpect and affection for feveral hours; and if it happened that the thought occurred and the noife was begun towards the even- 


\section{( 382$)$}

ing, thofe of their tribe who were at hand would join with them.

\section{H A P. XVI.}

A concije Character of the INDIANs.

7 HE character of the Indians, like that 1 of other uncivilized nations, is compofed of a mixture of ferocity and gentlenefs. They are at once guided by paffions and appetites, which they hold in common with the fierceft beafts that inhabit their woods, and are poffeffed of virtues that do ho nour to human nature.

In the following eftimate I fhall endeavour to forget on the one hand the prejudices of Europeans, who ufually annex to the word Indian epithets that are difgraceful to human nature, and who view them in no other light than as favages and cannibals; whilf with equal care I avoid any partiality towards them, as fome muft naturally arife from the favourable reception met with during my ftay among them.

At the fame time I thall confine my remarks to the nations inhabiting only the

out the

contin

are pe

ous ch.

my pre

and to

juncti

Tha

ful, in

watch

nature

and al

on the

reven

hear $v$

unhap

a diab

inflict

let us

piotur

both $i$

remer

have

that

tience 


\section{. ( 383$)$}

weftern regions, fuch as the Naudoweffies, the Ottagaumies, the Chipéways, the Winnebagoes, and the Saukies: for as throughout that diverfity of climates the extenfive continent of America is compofed of, there are people of different difpofitions and various characters, it would be incompatible with my prefent undertaking to treat of all thefe, and to give a general view of them as a conjunctive body.

That the Indians are of a cruel, revengeful, inexorable difpofition, that they will watch whole days unmindful of the calls of nature, and make their way through pathlefs, and almoft unbounded woods, fubfifting only on the fcanty produce of them, to purfue and revenge themfelves of an enemy, that they hear unmoved the piercing cries of fuch as unhappily fall into their hands, and receive a diabolical pleafure from the tortures they inflict on their prifoners, I readily grant ; but let us look on the reverfe of, this terrifying picture, and we thall find them temperate both in their diet and potations (it mult be remembered, that I fpeak of thofe tribes who have little communication with Europeans) that they withftand, with unexampled pa-. tience, the attacks of hunger, or the incle- 


\section{( 384$)$}

mency of the feafuns, and eftecm the gratification of their appetites, but as a fecondary confideration.

We thall likewife fee them fociable and humane to thofe whom they confider as their friends, and even to their adopted enemies; and ready to partake with them of the laft morfel, or to rilk theiplives in their defence.

In contradiction to the report of many other travellers, all of which have been tinctured with prejudice, I can affert, that notwithftanding the apparent indifference with which an Indian meets his wife and children after a long abfence, an indifference procceding rather from cuftom than infenfibiltty, he is not unmindful of the claims cither of connubial or parental tendernefs; the little ftory I have introduced in the preceding chapter of the Naudoweffie woman lamenting her child, and the immature death of the father, will elucidate this point, and enforce the affertion much better than the moft fudied arguments I can make ufe of.

Accuftomed from their youth to in numerable hardinips, they foon become fuperior to a fenfe of danger or the dread of death; and their fortitude, inplanted by nature and nur-

tured by

never $\mathrm{e}$

Thou

ftore of their foe gable an or in cir

If the to take delibera1 the extr timents, at the $\mathrm{f}$ tions of gacity of a lynx, a bound nefs of In the of a com for that to the is combine foul, ag and ban tion opp

They tion, or 


\section{( 385$)$}

tured by example, by precept, and accident, never experiences a moment's allay.

Though flothful and inactive whilft their ftore of provifion remains unexhaufted, and their foes are at a diftance, they are indefatigable and perfevering in purfuit of their game, or in circumventing their enemies.

If they are artful and defigning, and ready to take every advantage, if they are cool and deliberate in their councils, and cautious in the extreme either of difcovering their fentiments, or of revealing a fecret, they might at the fame time boaft of poffeffing qualifications of a more animated nature, of the fagacity of the hound, the penetrating fight of a lynx, the cunning of a fox, the agility of a bounding roe, and the unconquerable fiercenefs of the tyger.

In their public characters, as forming part of a community, they poffers an attachment for that band to which they belong, unknown to the inhabitants of any other country. They combine, as if they were actuated only by one foul, againft the enemies of their nation, and banifh from their minds every confideration oppofed to this.

They confult without unneceffary oppofition, or without giving way to the excite$\mathrm{C}$ c ments 


\section{( 386$)$}

ments of envy or ambition, on the meafures neceffary to be purfued for the deftruction of thofe who have drawn on themfelves their difpleafure. No felfifh views ever influence their advice, or obftruct their confultations. Nor is it in the power of bribes or threats to diminish the love they bear their country.

The honour of their tribe, and the welfare of their nation, is the firf and molt predominant emotion of their hearts; and from hence proceed in a great meafure all their virtues and vices. Actuated by this, they brave every danger, endure the moft exquifite torments, and expire triumphing in their fortitude, not as a perfonal qualitication, but as a national chara@eriftic.

From thence alfo flow that infatiable revenge towards thofe with whom they are at war, and all the confequent horrors that difgrace their name. Their uncultivated minds being incapable of judging of the propriety of an action, in oppofition to their paffions which are totally infenfible to the controuls of reafon or humanity, they know not how to keep their fury within any bounds, and confequently that courage and refolution which would otherwife do them honour, degenerates into a favage ferocity.

$\mathrm{Bu}$

limit:

treat

it wi

tions

prece

necef

to fos

have

that

event

enabl

mann

much

than

tion

of

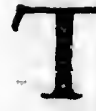

into

are $\mathrm{m}$ quois 


\section{$\left(3^{8} 7\right)$}

But this hort differtation muft fuffice; the limits of my work will not permit me to treat the fubject more copioully, or to purfue it with a logical regularity. The obfervations already made by my readers on the preceding pages, will, I truft, render it unneceffary; as by them they will be enabled to form a tolerably juft idea of the people I have been defcribing. Experience teaches, that anecdotes, and relations of particular events, however trifling they may appear, enable us to form a truer judgment of the manners and cuftoms of a people, and are much more declaratory of their real ttate, than the moft ftudied and elaborate difquifition without thefe aids.

C $\quad$ H $\quad$ A $\quad$ P. XVII.

Of their LANGUAGE, HIEROGLYP H I C K s, $\mho^{\circ} c$.

$7 \mathrm{HE}$ principal languages of the natives 1 of North America may be divided into fourclaffes, as they confift of fuch is are made ufe of by the nations of the Iroquois towards the eartern parts of it, the

$$
\mathrm{C} \mathrm{c}_{2}
$$

Chipe-

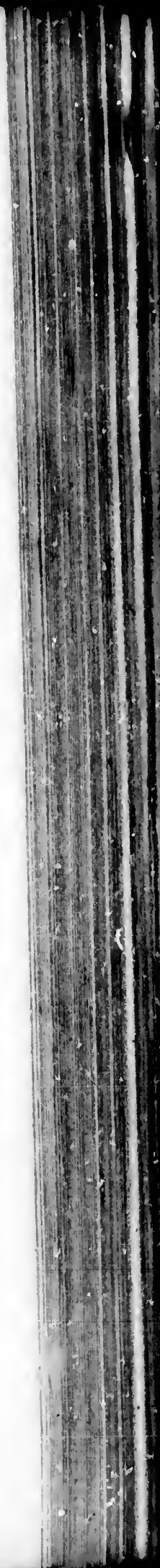




\section{$(388)$}

Chifeways or Algonlsins to the north-weft, this Naudoweffles to the weft, and the Cherokces, Chickafaws, \&c. to the fouth. One or other of thefe four are ufed by all the Indians who inhabit the parts that lie between the coalt of Labradore north, the Floridas fouth, the Atlantic Ocean eaft, and, as far as we can judge from the difcoveries hitherto made, the Pacific Ocean on the weft.

But of all thefe, the Chipiway tongue appears to be the moft prevailing; it being held in fuch efteem, that the chiefs of erery tribe, dwelling about the great lakes, or to the wefiward of thefe on the banks of the Miffirlippi, with thore as fai fouth as the Ohio, and as far north as Hudfon's Bay, confifting of more than thirty different tribes, fpeak this language alone in their councils, notwithftanding each has a peculir $r$ one of their own.

It will probably in time become univerfal among all the Indian nations, as none of them attempt to make excurfions to any great diftance, or are confidered as qualified to carry on any negociation with a difta $t$ band, unlefs they have acequired the Chipeway tongue.

At prefent, bcfides the Chiféways, to whom it is natural, the Ottawaws, the Sankies, the

Ottai the $\mathrm{t}$ main all co of di natio ver.

barol

bago tribe: this

$\mathrm{T}$ with ther fluor more guag polit are they wor Plai only the exp. can. 


\section{( 389 )}

Ottagaumies, the Killiftinoes, the Nipegons, the bands about Lake Le Pleuve, and the remains of the Algonkins or Gens de Terre, all converfe in it, with fome little variation of diales: but whether it be natural to thefe nations, or acquired, I was not able to difcover. I an however of opinion that the barbarous and uncouth dialect of the Winnebagoes, the Menomonies, and many other tribes will become in time totally extinct, and this be adopted in its ftead.

The Chipeway tongue is not ircumbered with any unneceffary tones or accents, neither are there any words in it that are fuperfluous; it is allo eafy to pronounce, and much more copious than any other Indian language.

As the Indians are unacquainted with the polite arts, or with the fciences. and as they are alfo ftrangers to ceremony or compliment, they neither have nor need an infinity of words wherewith to embellinh their difcourfe. plain and unpolifhed in their manners, they only make ufe of fuch as ferve to denominatc the neceffaries or conveniences of life, and to exprefs their wants, which in a ftate of nature can be but few. 


\section{( 390$)$}

I have annexed hereto a fhort vocabulary of the Chipeway language, and another of the Naudowefiies, but am not able to reduce them to the rules of grammar.

The latter is fpoken in a foft accent, without any guttural founds, fo that it may be learnt with facility, and is not difficult either to be pronounced or written. It is nearly as copious and expreffive as the Chipéway tongue, and is the moft prevailing language of any "he wiftern banks of the Miffiffippi; bcing ufe, according to their account, among all the nations that lie to the north of the Mefrorie, and extend as far weft as the fhores of the Pacific Ocean.

As the Indians are not acquainted with lettcrs, it is very difficult to convey with precifion the exact found of their words; I have however cndeavoured to write them as near to the manner in which they are expreffed, as fuch an uncertain mode will admit of.

Although the Indians cannot communicate their ideas by writing, yet they form certain hicroglyphicks, which, in fome meafure, ferve to perpetuate any extrao:dinary tranfaction, or uncommon event. Thus when they are on their excurfions, and either intend to procced, or have been, on any remarkable enterprize,

enter which to the tance ake

$\mathrm{Th}$ perfe of or can $\mathrm{f}$ W ed up Super guide that heads feari fies, war, befor pany lowi

$\mathrm{H}$ the coal fabf exp of $t$ left 


\section{( 391$)$}

enterprize, they peel the bark from the trees which lie in their way, to give intelligence to tho e parties that happen to be at a diftance, of the path they muft purfue to overake them.

The following inftance will convey a more perfect idea of the methods they make ufe of on this occafion, than any expreffions I can frame.

When I left the Miffifippi, and proceeded up the Chipéway River in my way to Lake Superior, as related in my Journal, my guide, who was a chief of the Chipéways that dwell on the Ottawaw Lake, near the heads of the river we had juft entered, fearing that fome parties of the Naudoweffies, with whom his nation are perpetually at war, might accidentally fall in with us, and before they were apprized of being in company, do us fonie mifchief, he took the following fteps.

He peeled the bark from a large tree near the entrance of the river, and with woodcoal mixed with bears-greafe, their ufual fabftitute for ink, made in an uncouth but expreffive manner, the figure of the town of the Ottagaumies. He then formed to the left, a man dreffed in flkins, by which he intended 


\section{$\left(39^{2}\right)$}

intended to reprefent a Naudoweffie, with a line drawn from his mouth to that of a deer, the fymbol of the Chipéways. After this he depictured ftill farther to the left, a canoe as proceeding up the river, in which he placed a man fitting with a hat on; this figure was defigned to reprefent an Englifhman, or myfelf, and my Frenchman was drawn with a handkerchief tied round his head, and rowing the canoe; to thefe he added feveral other fignificant emblems, among which the pipe of peace appeared painted on the prow of the canoe.

The meaning he intended to convey to the Naudoweffies, and which I doubt not appeared perfectly intelligible to them, was, that one of the Chipéway chiefs had received a fneech from fome Naudoweffic chiefs at the town of the Ottagaumies, defiring him to conduct the Englinman who had lately been a nong them, up the Chipéway river; and that they thereby required, that the Chipéway notwithftanding he was an avowed enemy, hould not be molefted by them on his paffage, as he had the care of a perfon whom they efteemed as one of their nation. 


\section{( 393 )}

Some anthors have pretended that the Indians have armorial bearings, which they blazon with great exactnels, and which diftinguinh one nation from another; but I never could obferve any other arms among them, than the fymbols already defcribed:

A Thort Vocabulary of the Chipéway Language.

N. B. This people do not make ufe either of the confonants $\mathrm{F}$ or $\mathrm{V}$.

A

Englif.

$A$ B OVE

Admirable

Atterwards

All

Always

Amifs

Arrive

Ax

Afhes

Affift
Cbipérway.

Spimink

Packiton

Pilawah

Mipidach

Kokinum

Kokali

Napitch

Takouchin

Agacwet

Pingoe

Mawinewah 
$394 \quad$

B

\section{Englifh.}

Ball

Bag, or tobacco-pouch Cafpetawgan

Barrell

Beat

Bear, a

Béar, a young oné

Beaver

Beaver's 1kin

$\mathrm{Be}$, or to be

Beard

Becaufe

Believe

Belly

Black

Blood

Body

Bottle

Brother

Brandy, or Rum

Bread

Breech

Breeches

Buck
Chipéway.

Alewin

Owentawgan

Pakkite

Mackwah

Makon

Amik

Apiminiquè

Tapaiê

Mifchiton

Mewinch

Tilerimah

Mifhemout

Markaute

Mifkow

Yoe

Shirhego

Neconnis

Scuttawawbah

Paboufhigan

Mifcoufab

Kipokitie Koufab

Wafketch
Englif

Canoe

Call

Chief, a

Carry

Child, o

Coat

Cold, I a

Come or

Come to

Comrade

Concern

Corn

Coverin

Country

Courage Cup

Dance

Dart

Die, to

Difh

Dog

Dead

Devil, c

Dog, a 


\section{( 395$)$}

C

Englifh:

Canoe

Call

Chief, a

Carry

Child, or Children

Coat

Cold, I am

Come on

Come to

Comrade

Concerned

Corn

Covering, or a Blanket Wawbewion
Country

Courage

Cup

Dance

Dart

Die, to

Dißh

Dog

Dead

Devil, or evil Spirit

Dog, a little one.
Chipérway.

Cheman

Tefhenekaw

Okemaw

Petou

Bobelofhin

Capotewian

Kekatch

Moppa

Pemotcha

Nechee

Tallemiffi

Melomin
Endawlawkeen

Tagwawmiffii

Olawgan

D

Nemeh

Shefhikwee

Nip

Mackoan

Alim

Neepoo

Matcho-Manitou

Alemon

Done, 


\section{( 396$)$}

Englifs.

Done, it is done

Do

Doubtlefs

Drefs the kettle

Drink

Drunken

Duck

Earth

Eat

Each

Englin

Enough

Equal, or alike

Efteem

Eyes
Chipérway.

Shiah

Torbiton

Ontclatoubah

Poutwah

Minikwah

Ouifquiba

Chickhip

E

\section{Aukwin}

Owiffine

Pap gik

Sagaunooh

Mimilic

Tawbifcouch

Nawpetelimàw

Wilkinkhie

F

Faft

Fall

Far off

Fat

Friend

Father

Few, or little

Futigued

\section{Waliebic}

Ponkifin

Watfaw

Pimmitee

Niconnis

Noofah

Maungis

Taukwifr
Engli)

Field 1

Fire

Fire, $t$

Find

Finh

Fork

Former

Fort

Forwal

French

Freeze

Freeze

Full

Fuzee

God, o

Go by

Girl

Give

Glafs,

Good

Good

Gover

Gener

man

Grape:

Great 


\section{(397)}

Englifh.

Field fown

Fire

Fire, to ftrike

Find

Finh

Fork

Formerly

Fort

Forward

French

Freeze, to

Freezes hard

Full

Fuzee or Gun
Chipiway.

Kittegaumic

Scutta

Scutecke

Nantounawaw

Kickon

Naffawokwot

Pirwego

Wakaigon

Nopawink

Neehtegooth

Kiffin

Kiffin Magat

Mounkinet

Pakeffigan

\section{G}

God, or the Great Spirit Kitchi Manitou

Go by water

Girl

Give

Glafs, a mirror

Good

Good for nothing Malatal

Govern

General, or Com- $\}$ Kitchi Okimaiw mander in Chief $\}$ Smauganifh

Grapes

Great
Pimmifcaw

Jeckwaffin

Millaw

Wawbemo

Cawlatch

Tibarimaw

Shoamin

Manatou 


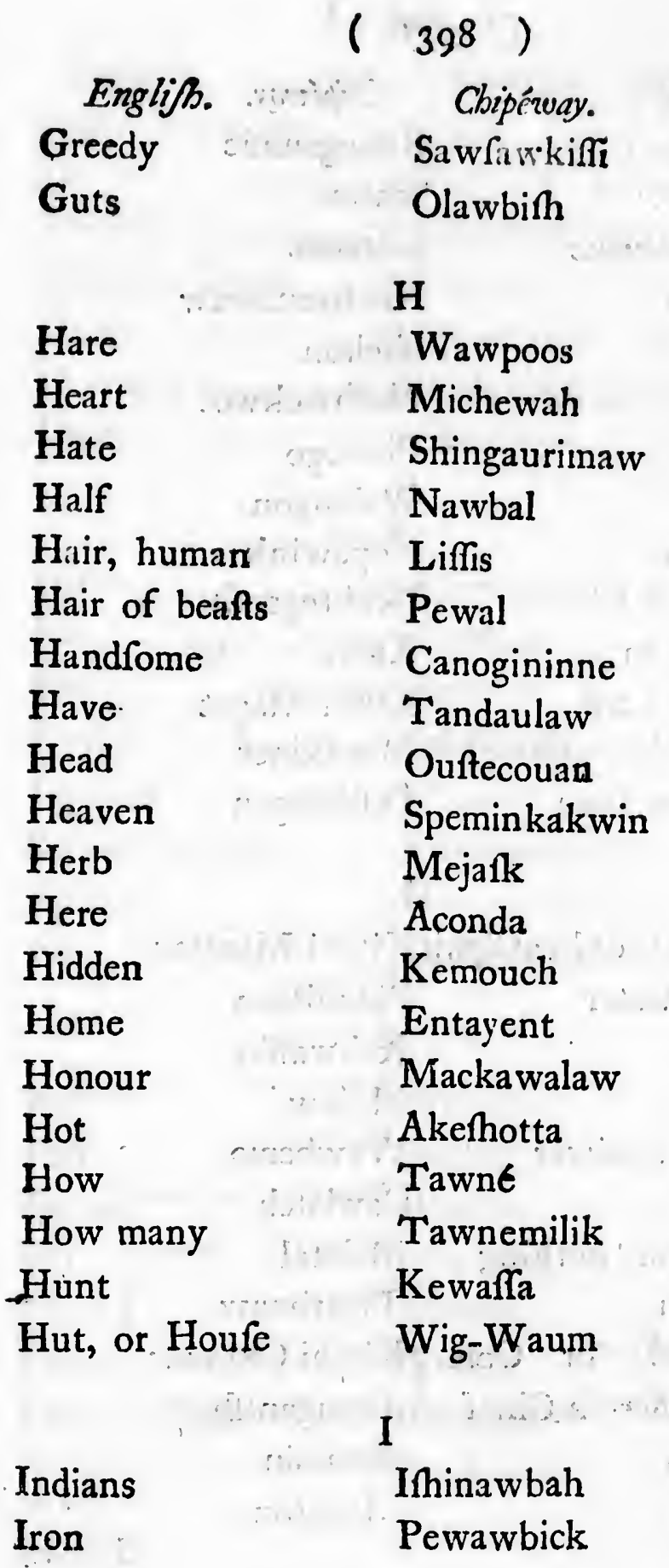

$E n$
Inland

Imme

India

Intire

Impol

It mig

Kettl

King,

Keep

Knife

Knife

Know

Lake

Laug

Lazy

Lame

Leavo

Lette

Life

Love

Long

Land

Lofe 


\section{( 399$)$}

Englifh

Inland

Immcdiately

Indian Corn

Intirely

Impoltor

It might be fo
Coppiway.

Minis

Webatch

Mittawmin

Nawpitch

Mawlawtiffie

Tawneendo

K

Kettle

Ackikons

King, or Chief

Keep

Knife

Okemaw

Ganwerimaw

Mockoman

$\mathrm{Knife}$ that is crooked

Know

Cootawgon

Thickeremaw

L

Lake

Laugh

Lazy

Lame

Leave

Letter

Life

Love

Long fince

Land Carriage

Lofe
Kitchigawmink

Pawpi

Kittimi

Kikekate

Pockiton

Mawfignaugon

Nouchimowin

Saukie

Shawhia

Cappatawgon

Packilaugué 


\section{( 400$)$}

Englis.

Lie down

Little
- Chipétway.

Weepemaw

Wauberheen.

Eng

Nougl notl

M

Meat

Much

Man

March, to go

Marry

Medicine

Merchandize

Moon

Mortar to pound in

Male

Miftrefs
Weas

Nibbilaw.

Alliffinape

Pimmouffie

Weewin

Mafkikic

Alokochigon

Debicot

Poutawgon

Nape

Neremoufin

Old

Otter

Other

Pipe

Part,

Play

Powde

Peace,

Pray

Proper

Prefen

Feninf

Shawbonkin

Pewitch

Irinee

Cawikkaw

Quick

Debicot

Kaw

Yoch.

Kakego

Kawmifchi

Kagutch

Regard

Red

Refolv

Relatio

Refpec 


\section{(401)}

Engliß.

Nought, good for
nothing Malatat

0

Old

Otter

Kauwerhine

Other

Nikkik

Coutack

Pipe

$P$

Part, what Part

Play

Poagan

Powder, gun, or duft Pingo

Peace, to make

Pecacotiche

Pray

Proper

Prefently

Peninfula

Tawlaimia

Sawfega

Webatch

Minniffin

Quick

2

Kegotch

R

Regard

Red

Refolve

Relation

Refpect

Wawbemo

Mifcow

Tibelindon

Tawwemaw

Tawbawmica

D d

Rain 


\section{(402)}

Engiifh.

Cbipéway.

Rain

Kinmewan

Robe

Ockolaw

River

Run, to

Sippim

Pitchebot

S

Sad

Talimiffie

Sail

Pemifcaw

Sack, or Bag

Mankimot

Sea, or large Lake

Agankitchigawmink

Shoes

Maukiffin

Ship or large Canoe

Sorry

Spirit

Spoon

Star

Steal

Stockings

Strong

Sturgeon

Sun

Sword

Surprizing

See

Kitchi Cheman

Nifcottiffie

Manitou

Mickwon

Alank

Kemautin

Mittaus

Ma!hkauwah

Lawmack

Kiffis

Simaugan

Etwah, Etwah

Wawbemo

Since

Mapedoh

Shirt

Papawkwéan

Slave

Wackan

$E_{1}$

Slee:

Sit d

Take

Teetl

That

Ther

This

Truly

Toger

Tobac

Tong

Tired

Too li

Toon

Thanl

To-me

To-mo

afte

Warric

Water

War

Way

Well tl

Sleep 


\section{( 403$)$}

Sleep

Englifh.

Sit down

Take

Teeth

That

There

This

Truly

Together

Tobaccó

Tongue

Tired

Too little

Too much

Thank you

To-morrow
Cbipeway.

Nippee

Mintepin

$\mathrm{T}$

Emaundah

Tibbit

Mawbah

Watfaudebi

Maundah

Kikit

Mawmawwee

Semau

Outon

Tawkonfie

Ofaummangis

Offauné

Mc。watch

Wawbunk

To-morrow, the day after

Oufwawbunk W

Warriors

Water

Semauganaurh

War Nebbi

Way

Nantaubaulaw

Well then! Mickon Tauneendah!

Dd 2 


\section{( 404$)$}

Englifb.

What is that?

What now?

Whence

Where

White

Who is there?

Wind

Winter

Woman

Wood

Wolf

Yefterday

Yet

Young

Yellow
Chipérway.

Wawwewin?

Quagonie?

Taunippi

Tah

Waube

Quagonie Maubah?

Loutin

Pepoun

Ickwee

Mittic

Mawhingon

\section{Y}

Petchilawgo

Minnewatch

Wifconekiffi

Wazzo.

Nine

Ten

Eleve

Twer

Thirt

Forty

Fifty

Sixty

Seven

Eight.

Ninet

Hund

Thoul

The Numerical Terms of the Chipeways,

One

Two

Three

Four

Five

Six

Seven

Eight
Panhik

Nincí

Niffou

Neau

Naran

Ningoutwaffou

Ninchowaffou

Niffowaffou
A Sho

Eng. Axe

Nine 


\section{( 405$)$}

Englifh.

Nine

Ten

Eleven

Chipéway. Shongaffou

Twenty : Mittauffou

'Thirty

Forty. Mittauffou Pàrhik

Fifty

Ninchtawnaw

Sixty

Niffou Mittawnaw

Neau Mittawnaw

Naran Mittawnaw

Seventy

$\{$ Nigoutwaffou Mit-

\{ tawnaw

$\begin{array}{ll}\text { Seventy } & \left\{\begin{array}{c}\text { Nifowaffou Mit- } \\ \text { tawnaw } \\ \text { tawnaw }\end{array}\right. \\ \text { Nighty } & \left\{\begin{array}{c}\text { Shongaffou Mittat- } \\ \text { naw }\end{array}\right. \\ \text { Hundred } & \left\{\begin{array}{c}\text { Mittauffou Mittaw- } \\ \text { naw } \\ \text { Mittaufou Mittaur- }\end{array}\right. \\ \text { Thoufand } & \left\{\begin{array}{c}\text { fou Mittawnaw. }\end{array}\right.\end{array}$

A Short Vocabutary of the Naudoweflic Language.

\section{A}

Englif.

Axe

Naudowelfie.

Anpaw

B

Beaver

Chawbah

Buffalo 


\section{(406)}

Englijô.

Buffalo

Bad

Broach

Bear, a
Naudowefle.

Tawtongo

Shejah

Muzahootoo

Wahkonfhejah

C

Canoe

Cold

Child, a Male

Child, Female

Come here

Waahtoh

Mechuetah

Wechoakfeh

Wahcheekfeh

Accooyouiyare

D

Dead

Deer

Dog

Negurh

Tohinjoh

Shungurh

E

Eat

Ears

Eyes

Evil

Echawmenaw

Nookah

Efhtike

Shejah

F

Fire

Father

Frenchman
Paahtah

Otah

Neehteegufh
Eng

Falls Frienc

Good

Give

Go aw

God,

Spir

Gun

Great

Gold

Hear

Horfe

Home,

Iloufe

Heaver

Iron

$\mathrm{I}$, or $\mathrm{m}$

King,

Kill 


\section{( 407.)}

Englifs. Naudowefre.

Falls of Water Owah Menah

Friend

Kitchiwah

Gorhtah

Good

Give

Accooyeh

Go away

Accoowah

God, or the Great \}Wakon Spirit

Gun

Great

Gold S

Muzah Wakon Tongo

Muzaham

H

Hear

Nookifhon

Horfe

Shuetongo

Home, or domeftic Shuah

IHoufe

Teebee

Heaven

Worhta Teebee

Iron

I, or me

I

Muzah

Meoh

K

King, or Chief

Kill

Otah

Negurhtaugaw

Little 


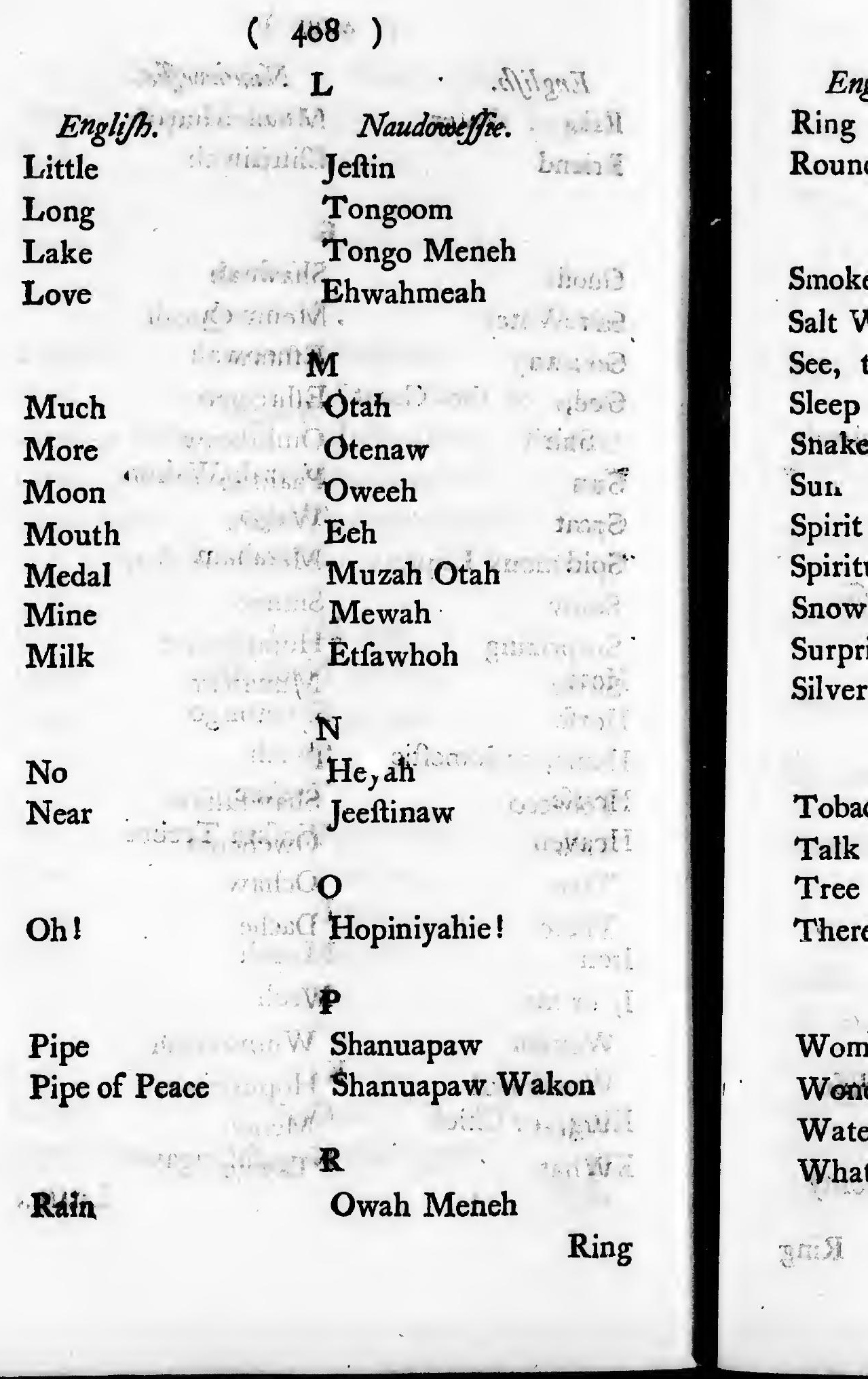




\section{(409)}

$\begin{array}{ll}\begin{array}{l}\text { Englifh. } \\ \text { Ring } \\ \text { Round }\end{array} & \begin{array}{l}\text { Naudowefie. } \\ \text { Muzamchupah } \\ \text { Chupah }\end{array} \\ \text { Smoke } & \text { S } \\ \text { Salt Water } & \text { Shaweah } \\ \text { See, to } & \text { Menis Queah } \\ \text { Sleep } & \text { Entaw } \\ \text { Snake } & \text { Enteemo } \\ \text { Suri } & \text { Omlifhcaw } \\ \text { Spirit } & \text { Paahtah } \\ \text { Spirituous Liquors } & \text { Wakon } \\ \text { Snow } & \text { Meneh Wakon } \\ \text { Surprizing } & \text { Sinnee } \\ \text { Silver } & \text { Hopiniayare } \\ & \text { Muzaham }\end{array}$

$T$

Tobacco

Shawfaffaw

Talk

Owehchin

Tree

Ochaw

There

Dachè

W

Woman

Winnokejah

Wondefful

Hopiniyare

Water

Meneh

What

$$
\text { Tawso : }
$$




\section{(410)}

Englifs.

Who is there?

Wicked
Naudoweflit.

Tawgodaché?

Heyahachta

$\mathbf{Y}$

You

Young

You are good

You are a Spirit

You are my good? Waithtah Kitchiwah Friend

No Good
Chee

Hawpawnaw

Wafhtah Chee

Wakon Chee
Chee

Heyah Warhtah.

Eng

Twen

Thirty

Forty

Fifty

Sixty

The Numerical Terms of the Naudowefles.

One

Two

Three

Four

Five

Six

Seven

Eight

Nine

Ten

Eleven
Wonchaw

Noompaw

Yawmonee

Toboh

Sawbuttee

Shawco

Shawcopee

Shahindohin

Nebochunganong

Wegochunganong

\{ Wegochnnganong

Wonchaw

Twenty 


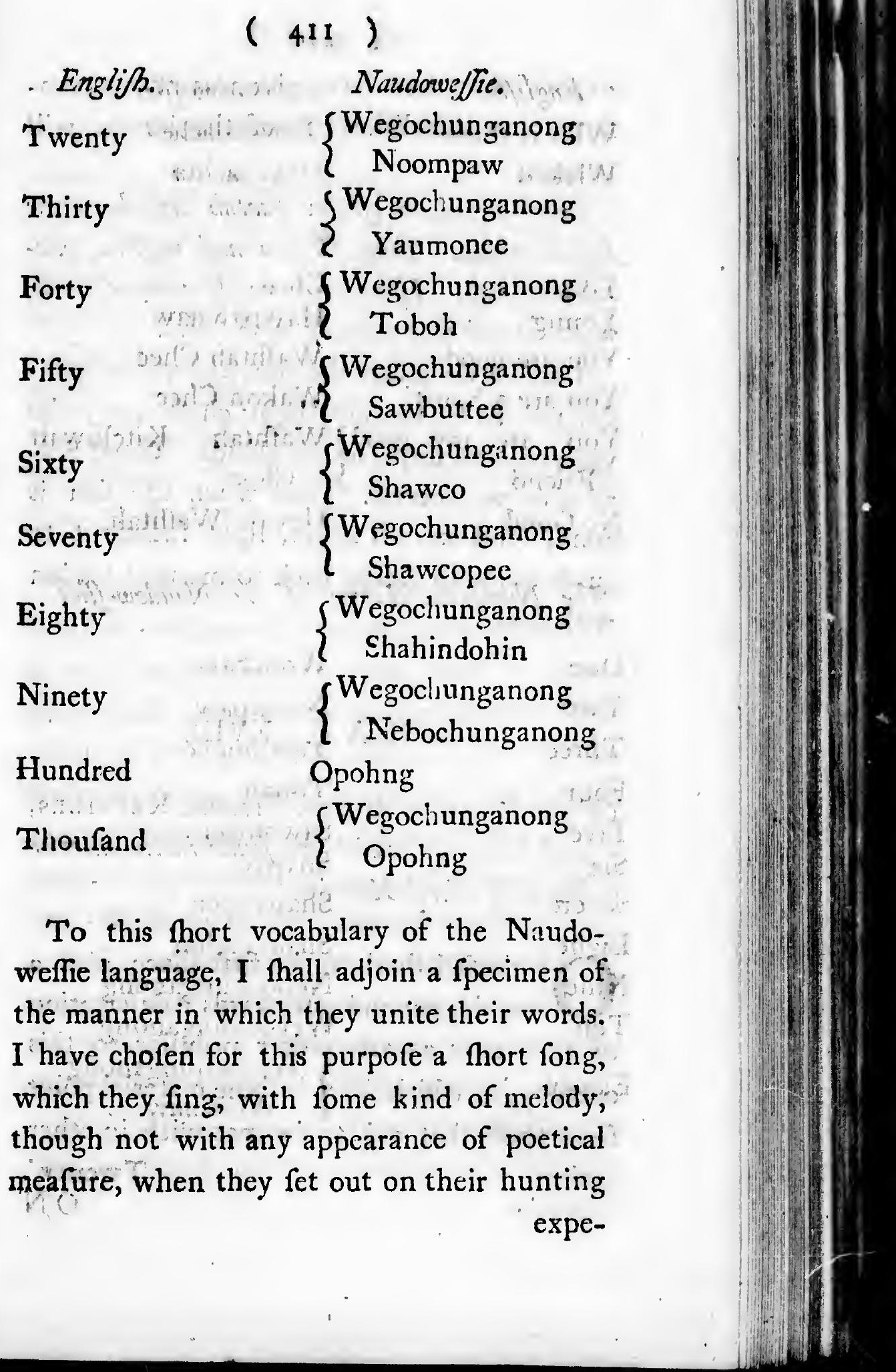




\section{(412)}

expeditions: and have given as near a tranflation as the difference of the idioms will permit.

Meob accoowab ef hturw paatab negußhtanugaw Sejab menab. Tongo Wakon meob wafila, paatab acboowab. Hipiniyabie oweeb accooyee meob, wo hia patab otob tobinj $b$ meob teeber.

I. will arife before the fun, and afcend yonder hill, to fee the new light chafe away the vapours, and difperfe the clouds. Great Spirit give me fuccers. And when the fun is gone, lend me, oh moon, light fufficient to guide me with fafety back to my tent loaden with deer!

\section{H A P. XVIII.}

Of the BEasts, Birds, Fishes, Reptiles, and IN SECTS, which are found in the interior Parts of Nortb America.

Q $F$ thefe $I_{\text {f }}$ hally in the firt place, give a catalogue, and afterwards a defcription of fuch only as are either peculiar to this country, or which differ in fome material point from thofe that are to be met with in other realms.

The the C Buffal

Carral cupin Racoc quanh the $W$ Beave

The fembl is con to be colou: tirely in the good me.

and $d$ our an clina: met Tho this $\mathrm{c}$ 


\section{$(413)$ \\ OF THE BEASTS.}

The Tyger, the Bear, Wolves, Foxes, Dogs, the Cat of the Mountain, the Wild Cat, the Buffalo, the Deer, the Elk, the Moofe, the Carrabou, the Carcajon, the Skunk, the Porcupine, the Hedge-hog, the Wood-chuck, the Racoon, the Martin, the Finer, the Muikquarh, Squirrels, Hares, Rabbits, the Mole, the Weazle, the Moufe, the Dormoufe, the Beaver, the Otter, the Mink, and Bats.

The TYGER. The Tyger of America refembles in Thape thofe of Africa and Afia, birt is confiderably fmaller. Nor does it appear to be fo fierce and ravenous as they are. The colour of it is a darkilh fallow, and it is intirely free from fpots. I faw one on an ifland in the Chipeway River, of which I had a very good view, as it was at no great diftance from me. It fat up on its hinder parts like a dog; and did not feom either to be apprehenfive of our approach, or to difcover any ravenous inclina:ions. It is however very feldom to be met with in this part of the world.

The BEAR. Bears are very numerous on this continent, but more particularly fo in the northern 


\section{$(4 \mathrm{I} 4)$}

northern parts of it, and contribute to fursilh both food and beds for almoft every Indian nation. Thule of. America differ in many refpects from thofe cither of Greenland or Ruffia, they being not only fomewhat fmaller, ut timorous and inoffenfive, unlefs they are pinclied by hunger, or friarting from a wound. The fight of a man terrines them: and a dog will put feveral to flight. They are extremely fond of grapes, and will climb to the top of the higheft trees in queft of them. This kind of food renders their flefh exceffively rich and finely flavoured; and it is confequently preferred by the Indians and traders to that of any oiher animal. The fat is very white, and befides being fweet and wholefome, is poffeffed of one valuable quality, which is, that it never cloys. The inhabitants of there parts conftantly anoint themfelves with it, and to its efficacy they in a great meafure owe their agility. The feaion for hunting the bear is during the winter; when they take up their abode in hallow trees, or make themfelves deps in the rcuts of thoie that arc blown down, the entrance of which they ftop up with branches of fir that lie fattered about. From thefe retreats it is faid they ftir not whillt the weather continues

fevere,

Sev
do
fup
for
tim
$T$
rica
wit
hov
fpe
nef
the

Eur

a m

the

herc

they

ther is of

clin

$\mathrm{T}$

Nor

lour

of a

four

ly $b$

grcy 


\section{( 415$)$}

Severe, and as it is well known that they do not provide themfelves with food, they are fuppofed to be enabled by nature to fubfift for fome months without, and during this time to continue of the fame bulk.

The WOLF. The wolves of North America are much lefs than thofe which are met with in other parts of the world. They have however, in common with the reft of their fpecies, a vildnefs in their looks, and a fiercenefs in their eyes; notwithftanding which they are far from being fo ravenous as the European wolves, nor will they ever attack a man, except they have accidentally fed on the flem of thofe flain in battle. When they herd together, as they often do in the winter, they make a hideous and terrible noife. In thefe parts there are two kinds; one of which is of a fallow colour, the other of a dun, inclining to black.

The FOX. There are two forts of foxes in North America, which differ only in their colour, one being of a reddifh brown, the other of a grey; thofe of the latter kind that are found near the river Miffiffippi, are extremely beautiful, their hair being of a fine filver grey. 


\section{$(416)$}

ifOGS. The dogs employed by the Indians in hunting appear to be all of the fame fpecies; they carry their ears erea, and greatly refemble a wolf about the head. They are exceedingly ureful to them in their hunting excurfions, and will attack the fierceft of the game they are in purfuit of They are alfo remarkable for their fidelity to their matters, but being ill fed by them are very troublefome in their huts or tents.

The CAT of the mountain. This creature is in shape like a cat, only much larger, The hair or fur refembles alfo the Akin of that domertic animal; the colour however differs, for the former is of a reddith or arange cait, but grow's lighter near the belly. The whole $\mathrm{fkin}$ is beautified with ble f fpots of different figures, of which thofe on the back are long, and thofe on the lower parts round. On the ears there are black Aripeq. This creature is nearly as fierce as a leopard, but will reldom attack a man.

The BUFFALO. This beaft, of which there are amazing numbers in thefe parts, is larger than an ox, has Thort black horns, with a large beard under his chin, and his head is fo full of hair, that it falls over his eyes, and gives him a frightful look. There

is a

haw

Shot

this

vere

dun

valu

the :

with

and

The

of a

wher

of th

ceedi

the n

Th

deer

and o

Their

pean,

horns

is the

they

tries.

$\mathrm{Th}$

fize, body 


\section{( 47$)$}

is a bunch on his back which begins at the haunches, and increafing gradually to the Thoulders, reaches on to the neck. Both this excrefcence and its whole body are covered with long hair, or rather wool, of a dun or moufe colour, which is exceedingly valuable, efpecially that on the fore part of the body. Its head is larger than a bull's, with a very hort neck'; the breaft is broad, and the body decreafes towards the buttocks. Thefe creatures will run away at the fight of a man, and a whole lierd will make off when they perceive a fingle dog. The flefh of the buffalo is excellent food, its hide exceedingly ufeful, and the hair very proper for the manufacture of various articles.

The DEER. There is but one fpecies of deer in North America, and thefe are higher and of a nimmer make than thofe in Europe. Their fhape is nearly the fame as the European, their colour of a deep fallow, and their horns very large and branching. This beaft is the fwiftent on the American plains, and they herd together as they do in other countries.

The ELK greatly excceds the deer in fize, being in bulk equal to a horfe. Its body is thaped like that of a deer, only its. E e tail 


\section{(418)}

tail is remarkably thort, being not more than three inches long. The colour of its hair, which is grey, and not unlike that of a camel, but of a more reddifh caft; is nearly three inches in length, and as coarfe as that of a horfe The horns of this creature grow to a prodigious fize, extending fo wide that two or three perfons might fit between them at the fame time. They are not forked like that of a deer, but have all their teeth or branches on the outer edge. Nor does the form of thofe of the elk refemble a deer's, the former being flat, and eight or ten inches broad, whereas the latter are round, and confiderably narrower. They thed their horns every year in the month of February, and by Auguft the new ones are nearly arrived at their full growth. Notwithftanding their fize, and the means of defence nature has furnifhed them with, they are as timorous as a deer. Their fkin is very ufeful, and will drefs as well as that of a buck. They feed on grafs in the fummer, and on mofs or buds in the winter.

The MOOSE is nearly about the fize of the elk, and the horns of it are almoft as enormous as that animal's; the ftem of them however are not quite fo wide, and they

bran

This

Tho

tail i:

and 1

feet 1

unde

a mas

fidera

grey,

elaftic

it wil

excee

very

which

efteen

confif

when

cious 0

being

The $\mathrm{p}$

which

fwiftn

of the

forefts,

Thoug

never

found

branch 


\section{( 419$)$}

branch on both fides like thofe of a deer. This creature alfo theds them every year. Though its hinder parts are very broad, its tail is not above an inch long,. It has fet and legs like a camel, its head is about two feet long, its upper lip much larger than the under, and the noftrils of it are fo wide that a man might thruft his hand into them a confiderable way. The hair of the moofe is light grey, mixed with a blackin red. It is very elaftic, for though it be beaten ever fo long, it will retain its original hape. The Aen is exceeding good food, eafy of digettion, and very nourihing. The nofe, or upper lip, which is large and loofe from the gums, is efteemed a great delicacy, being of a firm. confiftence, between marrow and griftle, and when properly dreffed, affords a rich and lufcious difh. Its hide is very proper for leather, being thick and ftrong, yet foft and pliable. The pace of this creature is always a trot, which is 10 expeditious, that it is exceeded in fwiftners but by few of its fellow inhabitants of thefe woods. It is generally found in the forefts, where it feeds on mols and buds. Though this creature is of the deer kind, it never herds as thofe do. Moft authors confound it with the elk, deer, or carrabou, but 


\section{( 420$)$}

it is a fpecies totally different, as might be difcovered by attending to the defcription I have given of each.

The CARRABOU. This beaft is not near fo tall as the moofe, however it is fomething like it in fhape, only rather more heavy, and inclining to the form of the ars. The horns of it are not flat as thofe of the elk are, but round like thofe of the deer; they alfo meet nearer together at the extremities, and bend more over the face, than either thofe of the elk or moofe. It partakes of the fwiftnefs of the deer, and is with diffculty overtaken by its purfuers. The fefh of it likewife is equally good, the tongue particularly is in high efteem. The $\mathrm{fkin}$ being fmooth and free from veins, is as valuable as Thamoy.

The CARCAJOU. This creature, which is of the cat kind, is a terrible enemy to the preceding four fpecies of beafts. He either comes upon them from fome concealment unperceived, or climbs up into a tree, and taking his fation on fome of the branches, waits till one of them, driven by an extreme of heat or cold, takes Melter under it; when he faftens upon his neck, and opening the jugular vein, foon brings his prey to the

grou

tail,

his a

to' $1 \mathrm{~h}$

the $n$

has a

times

pore.

Th

dinar

duce.

of th

mifta

ferent

fur is

ed in

pears

black,

ed! "1

of a

and $h$

are or

as he

great

water

time

tainte

rence 


\section{( $42 i)$}

ground. This he is enabled to do by his long tail, with which he encircles the body of his adverfary; and the only means they have to' hun their fate, is by flying immediately to the water, by this method, as the carcajou has a great dinike to that element, he is fometimes got rid of before he can effect his purpofe.

The SKUNK. This is the moft extraordinary animal that the American woods produce. It is rather lefs than a pole-cat, and of the fame fpecies; it is therefore often miftaken for that creature, but is very different from it in many points. Its fkin or fur is long and thining, of a dirty white mixed in fome places with black, fo that it appears to be fhaded in particular parts with black, without being either fpotted or ftriped. "Its tail is long and very bufhy like that of a fox, and it lives chiefly in the woods and hedges. But its extraordinary powers are only fhewn when it is purfued. As foon as he finds himfelf in danger he ejects to a great diltance from behind a fmall ftream of water, of fo fubtile a nature, and at the fame time of fo powerful a fmell, that the air is tainted with it for half a mile in circumference; and his purfuers, whether men or dogs, 


\section{( 422$)$}

dogs; being almoft fuffocated with the ftench, are obliged to give over the purfuit. On this account he is called by the French, Enfant du. Diable, the Child of the Devil; or Bete Puante, the Stinking Beaft. It is almoft impolfible to defcribe the noifome effects of the liquid with which this creature is fupplied by nature for its defence. If a drop of it falls on your cloaths, they are rendered fo difagreeable that it is impoffible ever after to wear them; or if any of it enters your eyelids, the pain becomes intolerable for a tong time, and perhaps at laft you lofe your fight. The fmell of the fkunk, though thus to be dreaded, is not like that of a putrid carcafe, but a ftrong foetid effluvia of munk, which difpleafes rather from its penetrating power than from its naufeoufnefs. It is notwithftanding confidered as conducive to clear the head and to raife the fpirits. This water is fuppofed by naturalifts to be its urine, but I have diffected many of them that I have fhot, and have found within their bellies, near the urinal veffels, a fmall receptacle of water, toially diftinat from the bladder which contained the urine, and from which alone I an fatisfied the horrid ftench proceeds After having taken out with great care the bag hour

that tice diab

$T$

rican

fmall

and $n$

very

in its

forme

which

bles $n$

vered inche: thicks quills. hollor grow creatu which pierce fink q ed wit wherein 


\section{(. 423$)$}

wherein this water is lodged, I have frequently fed on them, and have found them very fweet and good; but one drop emitted. taints not only the carcafe, but the whole houfe, and renders every kind of provifions that are in it unfit for ufe. With great juftice therefore do the French give it fuch a diabolical name.

The PORCUPINE. The body of an American porcupine is in bulk about the fize of a fmall dog, but it is both horter in length, and not fo high from the ground. It varies very much from thofe of other countries both: in its thape and the length of its quills. The former is like that of a fox, except the head, which is not fo tharp and long, but refembles more that of a rabbit. Its body is covered with hair of a dark brown, about four inches long, great part of which are the thicknefs of a fraw, and are termed its quills. There are white, with black points, hollow and very ftrong, efpecially thofe that grow on the back. The quills ferve this creature for offenfive and defenfive weapons, which he darts at his enemies, and if they pierce the flem in the leaft degree, they will fink quite into it, and are not to be extracted without incifion. The Indians ufe them. 


\section{(424)}

for boring their ears and nofes to infert their pendants, and alfo by way of ornament to their ftockings, hair, \&c. befides which they greatly efteem the flefh.

The WOOD-CHUCK is a ground animal of the fur kind, about the fize of a martin, being nearly fifteen inches long, its body however is rounder, and his legs fhorter; the fore paws of it are broad, and conftructed for the purpofe of digging holes in the ground, where it burrows like a rabbit; its fur is of a grey colour on the reddifh caft, and its flefh tolerable food.

The RACOON is omewhat lefs in fize than a beaver, and its feet and legs are like thofe of that creature, but fhort in propor. tion to its body, which refembles that of the badger. . The thape of its head is much like a fox's, only the ears are thorter, more round and naked, and its hair is alfo fimilar to that animal's, being thick, long, foft, and black at the ends. On its face there is a broad ftripe that runs acrors it, and includes the eyes, which are large. Its muzzle is black, and at the end roundifh like that of a dog; the teeth are alfo fimilar to thofe of a dog in number and thape; the tail is long and round, with annular fripes on it like thofe of a cat;

the

with

climt

the

ufe o

and

this

Septe

on $\mathrm{k}$

$\mathrm{Tl}$

fquir

legs:

ter.

and $\mathrm{i}$

cât.

a bro

more

fkins

than

long

it re:

is no

$\mathrm{Tl}$

term

fords

beav

ties

thin the 


\section{( 425$)$}

the feet have five long flender tocs armed with fharp claws, by which it is enabled to climb up trees like a nonkey, and to run to the very extremities of the boughs. It makes ufe of its fore feet in the manner of hands, and feeds itfelf with them." The fleth of this creature is very good in the months of September and Oetober, when fruit and nuts, on which it likes to feed, are plenty.

The MARTIN is rather larger than a fquirrel, and fomewhat of the fame make; its legs and claws however are confiderably fhorter. Its ears are thort, broad and roundifh, and its eyes thine in the night like thofe of a cat. The whole body is covered with fur of a brownith colour, and there are fome in the more northern parts which are black; the Akins of the latter are of much greater value than the others. The tail is covered with long hair, which makes it appear thicker than it really is. Its flefl is fometimes eaten, but is not in any great efteem.

The MUSQUASH, or MUSK-RAT, is fo termed for the exquifite mufk which it affords. It appears to be a diminutive of the beaver, being endowed with all the properties of that fagacious animal, and wants nothing but fize and ftrength, being not much bigger 


\section{$(426)$}

bigger than a large rat of the Norway breed, to rival the creature it fo much refembles. Was it not for its tail, which is exactly the fame as that of the European rat, the Aructure of their bodies is fo much alike, efpecially the head, that it might be taken for a fmall beaver. Like that creature it builds itfelf a cabbin, but of a lefs perfect conftruction, and takes up its abode near the fide of fome piece of water. In the fpring they leave their retreats, and in pairs fubfift on leaves and roots till the fummer comes on, when they feed on ftrawberries, rafberries, and fuch other fruits, as they can reach. At the approach of winter they feparate, when each takes up its lodging apart by itfelf in fome hollow of a tree, where they remain quite unprovided with food, and there is the greateft reafon to believe, fubfift without any till the return of fpring.

SQUIRRELS. There are five forts of fquirrels in America; the red, the grey, the black, the variegated, and the flying. The two former are exactly the fame as thofe of : Europe; the black are fomewhat larger, and differ from them only in colour; the variegat-; ed alfo refemble them in Thape and figure, but are very beautiful, being finely ftriped with

with and 1 mucl five i colov parts of th a mer its fo bled if the this 1 out 1 is $a b$ with fame tame $\mathrm{Tl}$ fo of lities accou ever who and anim it. ? whic wate 


\section{( 427 )}

with white or grey, and fometimes with red and black. The American flying fquirrel is much lefs than the European, being not above five inches long, and of a ruffet grey or ancolour on the back, and white on the under parts. It has black prominent eyes like thofe of the moufe, with a long flat broad tail. By a membrane on each fide which reaches from its fore to its hind legs, this creature is cnabled to leap from one trec to another, cven if they fand a confiderable diftance apart; this loofe Akin, which it is enabled to ftretch out like a fail, and by which it is buoyed up, is about two inches broad, and is covered with a fine hair or down. It feeds upon the fame provifions as the others, and is eafily tamed.

The BEAVER. This creature has been fo often treated of, and his uncommon abilities fo minutely defcribed, that any further account of it will appear unneceffary; however for the benefit of thofe of iny readers who are not fo well acquainted with the form and properties of this fagacious and ufeful animal, I thall give a concife defcription of it. The beaver is an amphibious quadruped; which cannot live for any long time in the water, and it is faid is even able to exift entirely 


\section{( 428$)$}

tirely without it, provided it has the convenience of fometimes bathing itfelf. The larg.: eft beavers are nearly four ficet in length, and about fourteen or fifteen inches in breadth ove: the haunches; they weigh about fixty pounds. Its head is like that of the otter, but larger; its fnout is pretty long, the eyes fmall, the ears fhort, round, hairy on the outfide, and fmooth within, and its teeth very long; the under teeth ftand out of their mouths about the breadth of three finger,; and the upper half a finger, all of which are broad, crooked, Atrong, and tharp; befides thofe teeth cailed the incifors, which grow double, are fet very deep in their jaws, and bend like the edge of ati axe; they have fixteen grinders, eight on each fide, four above and four below directly oppofite to each other. With the former they are able to cut down trees of a confiderable fize, with the latter to break the liardeft fubitance. Its legs are fhort, particularly the fore legs, which are only four or five inches long, and not unlike thofe of a baciger; the tocs of the fore feet: are feparate, the nails placed obliquely, and arc hollow like quills; but the hind fect are quite different, and furnimed with membranes between the toes. By this incans it

fwis

anin

fem

of

hing

tho:

witl

join

abo

a li

hex

abo

bro:

ove

It is

whe

ally

lour

the

the

qui

colc

app

two

whi

is $\mathrm{g}$

the

call 


\section{( 429 )}

can walk, though but flowly, and is able to fwim with as much eafe as any other aquatic animal. The tail has fomewhat in it that refembles a firh, and feems to have no manier of relation to the reft of the body, except the hind feet, all the other parts being fimilar to thofe of land animals. The tail is covered with a flin furnifhed with fcales, that are joined together by a pellicle; thefe fcales are about the thicknefs of parchment, nearly a line and half in length, and generally of a hexagonical figure, having fix corners; it is about eleven or twelve inches in length, and broader in the iniddle, where it is four inches over, than either at the root or the extremity. It is about two inches thick near the body where it is alınoft round, and grows gradually thinner and flatter to the end. The colour of the beaver is different according to the different climates in which it is found In the moft northern parts, they are generally quite black; in more temperate, brown; their colour becoming lighter and lighter as they approach towards the fouth. The fur is of two forts all over the body, except at the feet, where it is very hort; that which is the longeft is generaily in !cngth about an inch, but on the back it ionecimes extends to two inches,

gradually 


\section{$\left(43^{\circ}\right)$}

gradually diminifhing towards the head and tail. This part of the fur is harm, coarfe, and thining, and of little ufe; the other part confifts of a very thick and fine down, fo foft that it feels almoft like filk, about three quarters of an inch in length; and is what is commonly manufactured. Caftor, which is ufeful in medicine, is produced from the body of this creature; it was formerly believed to be its tefticles, but later difcoveries have fhown that it is contained in four bags fituated in the lower belly. Two of which, that are called the fuperior from their being more elevated than the others, are filled with a foft refinous adhefive matter, mixed with fmall fibres, greyin without, and yellow within, of a ftrong difagreeable and penetrating fcent, and very inflammable. This is the true caftoreum; it hardens in the air, and becomes brown, brittle and friable. The inferior bags contain an unctuous liquor like honey; the colour of which is a pale yellow, and its odour fomewhat different from the other, being rather weaker and more difagreeable; it however thickens as it grows older, and at lengtn becomes about the confiftence of tallow. This has alfo its particular ufe in medicine, but it is not fo valuable as the true caftoreum. ing fubri are a they or th tion. ons, : houfe when adjac fect $b$ finall For $t$ trees, that to bu the c prope felve: their alfo $\mathrm{p}$ ward: way tinua cut it to thi place 


\section{( $\left.43^{\mathrm{r}}\right)$}

The ingenuity of thefe creatures in building their cabbins, and in providing, for their fubfiftence is truly wonderful. When they are about to chufe themfelves a habitation, they affemble in companies fometimes of two or three hundred, and after mature deliberation fix on a place where plenty of provifons, and all neceffaries are to be found. Their houfes are always fituated in the water, and when they can find neither lake nor pond adjacent, they endeavour to fupply the defect by ftopping the current of fome brook or finall river, by means of a caufeway or dam. For this purpofe they fet about felling of trees; and they take care to chufe out thofe that grow above the place where they intend to build, that they might fwim down with the current. Having fixed on thofe that are proper, three or four beavers placing themfelves round a large orie, find means with their ftrong teeth to bring it down. They alfo prudently contrive that it hall fall towards the water, that they may have the lefs way to carry it. After they have by a continuance of the fame labour and induftry, cut it into proper lengths, they roll thefe into the water, and navigate them towards the place where they are to be employed. With- 


\section{$\left(: 43^{2}\right)$}

out entering more minutely into the meafures they purfue in the conftruction of their dams, I. Thall only remark, that having prepared a kind of mortar with their feet, and laid it on with their tails, which they had before made ufe of to tranfport it to the place where it is requifite; they conftruct them with as much folidity and regularity as the moft experienced workmen could do. The formation of their cabbins is no lefs amazing. Thefe are either built on piles in the middle of the frnall lakes they have thus formed, on the bank of a river, or at the extremity of fome point of land that advances into a lake. The figure of them is round or oval, and they are faThioned with an ingenuity equal to their dams. Two thirds of the edifice ftand above the water, and this part is fufficiently capacious to contain eight or ten inhabitants. Each beaver has his place affigned him, the floor of which he curisunly frews with leaves, or fmall branches of the pine tree, fo as to render it clean and comfortable; and their cabbins are all fituated fo contiguous to each other, as to allow of an eafy communication. The winter never furprizes thefe animals before their bufinefs is completed, for by the latter end of Sentember their houfes are finifhed,

ner

enu:

to $b$

fill a

but

$T$

phibi

is ve

body

fider:

eyes;

fame.

otter

a bea

withe

of a

mer

the la

fame

ftoma

of $a$

likew

with 


\section{( 433 )}

nithed, and their ftock of provifions are generally laid in. The e confint of fuall pieces of wood whofe texture is foft, fuch as the poplar, the afpin, or willow, \&c. which they lay up in piles, and difpofe of in furh minner as to preferve therr moifture. Was I to enumerate every inftance of fagacity that is to be difcovered in there animals, they would fill a volume, and prove not only entertaining but inftructive.:

The OTTER. This creature alfo is amphibious, and grcatly refenbles a beaver, but is very different from it in many refpecis. its body is nearly as long as a beaver's, but confiderably lefs in all its parts. The muzzle; eyes, and the form of the head are nearly the fame, but the teeth are very unlike, for tho otter wants the large incifors or nippers that a beaver has; inftead of thefe, all his testh, without any diftinstion, are thaped like thofe of a dog or wolf. The hair alfo of the formeris not half fo long as that belonging to the latter, nor is the crlour of it exantl; the fame, for the hair of an otter under the neck, ftomach, and belly, is more greyin than that of a beaver, and in many other refpects it likewife varies. This animil, which is met with in moft parts of the world, bat in much If 1 greater 


\section{( 434$)$}

greater numbers in North America, is very mifchievous, and when he is clofely purfued, will not only attack dogs but men. It gene- rally feeds upon fifh, efpecially in the fummer, but in the winter is conterited with the bark of trees, or the produce of the fields. Its flem both taftes and fmells of firh, and is not wholefome food, though it is fometimes eaten through neceffity.

The MINK is of the otter kind, and fubfifts in the fame manner: In thape and fize it refembles a pole-cat, being equally long and flender. Its fkin is blacker than that of an otter, or almoft any other creature, " as " black as a mink," being a proverbial expreffion in America; it is not however fo valuable, though this greatly depends on the feat fon in which it is taken. Its tail is round like that of a fnake, but growing flattion towards the end, and is entirely without hair. An agreeable mufky fcent exhales from its body; and it is met with near the fources of rivers on whofe banks it chiefly lives.

\section{OF THE BIRDS.}

The Eagle, the Hawk, the Night Hawk, the Firh Hawk, the Whipperwill, the Raven, the Crow, the Owl, Parrots, the Peli-

can, the Teal key,

Quail pecke low. Redb Night Wren

Th of eag grey, fimilar The the ha wings ly like it is co darker. evenin it flies gambol Before at an a gether ferved 


\section{( 435 )}

can, the Crane, the Stork, the Cormorant, the Heron, the Swan, the Goofe, Ducks, Teal, the Loon, the Water-Hen, the Turkey, the Heath-cock, the Partridge, the Quail, Pigeons, the Snipe, Larks, the Woodpecker, the Cuckoo, the Blue Jay, the Swallow, the Wakon Bird, the Blackbird, the Redbird, the Thrum, the Whetfaw, the Nightingale, the King Bird, the Robin, the Wren, and the Humming Bird.

The EAGLE There are only two forts of eagles in thefe parts, the bald and the grey, which are much of the fame fize, and fimilar in thape to thofe of other countries.

The NIGHT HAWK. This Bird is of the hawk fpecies; its bill being crooked; its wings formed for $f_{\text {wiftnefs, }}$ and its Thape nearly like that of the common hawk; but in fize it is confiderably lefs, and in colour rather darker. It is fcarcely ever feen but in the evening, when at the approach of twilight, it flies about, and darts itfelf into wanton gambols at the head of the belated traveller. Before a thunder-hower thefe birds are feen at an amazing height in the air, affembled together ingreat numbers, as fwallows are ob-: ferved to do on the fame occafion. 


\section{( 436$)$}

The FISH HAWK greatly refembles the latter in its thape, and receives his name from his food, which is generally firh; it Ikims over the lakes and rivers, and fometimes feems to lie expanded on the water, as he hovers fo clofe to it, and having by fome attractive power drawn the filh within its reach, darts fuddenly upon them. The charm it makes ufe of is fuppofed to be an oilcontained in a fmall bag in the body, and which nature has by fome means or other fupplied him with the power of ufing for this purpofe; it is however very certain that any bait touched with a drop of the oil collected from this bird is an irrefiftible lure for all forts of firh, and infures the angler great fuccefs.

The WHIPPERWILL, or as it is termed by the Indians, the Muckawifs. This extraordinary bird is fomewhat like the laft-mentioned in its Thape and colour, only it has fome whitith Atripes acrofs the wings, and like that is feldom ever feen till after fun-fet. It alfo is never met with but during the fpring and fummer months. As foon as the Indians are informed by its notes of its return, they conclude that the froft is entirely gone, in which they are feldom deceived; and on receiving this affurance of milder weather, be-

and

tlen

hou inh

I fou

tren

fine

thad

$T$

thef

a pe ropo 


\section{( 437$)$}

gin to fow their corn. It acquires its name by the noife it makes, which to the people of the colonies founds like the name they give it Whipper-will; to an Indian ear Muck-a-wifs. The words, it is true, are not alike, but in this manner they frike the imagination of each; and the circumftance is a proof that the fame founds, if they are not rendered certain by being reduced to the rules of orthography, might convey different ideas' to different people. As foon as night comes on, thefe birds will place themfelves on the fences, ftumps, or ftones that lic near fome houfe, and repeat their melancholy notes without any variation till midnight. The Indians, and fome of the inhabitants of the back fettlements, think if this bird perches on any houfe, that it betokens fome minhap to the inhabitants of it.

The OWL. The only fort of owls that is found on the banks of the Miffiffippi, is extremely beautiful in its plumage, being of a fine deep yellow or gold colour, pleafingly shaded and fpotted.

The CRANE. There is a kind of crane in thefe parts, which is called by Father Hennepin a pelican, that is about the fize of the European crane, of a greyin colour, and with long 


\section{( $\left.43^{8}\right)$}

long legs; but this fpecies differs from all others in its bill, which is about twelve inches long, and one inch and half broad, of which breadth it continues to the end, where it is blunted, and round like a paddle; its tongue is of the fame length.

DUCKS. Among a variety of wild ducks, the different fpecies of which amount to upwards of twenty, I thall confine my defcription to one fort, that is, the wood duck, or as the French term it, Canard branchus. This fowl receives its name from its frequenting the woods; and perching on the branches of trees which no other kind of water fowl (a characteriftic that this.ftill preferves) is known to do. It is nearly of a fize with other ducks, its plumage is beautifully variegated, and very brilliant: The tleph of it alro, as it feeds but little on firh, is finely flavoured; and much fuperior to any other fort.

The TEAL. I have already remarked in my Journal, that the teal found on the Fox river, and the head branches of the Miffifippi, are perhaps not to be equalled for the fatnefs and delicacy of their fleth by any other in the world. In colour thape, and fize they are very little different from thofe found in other countries.

furfe

the 1

lent

TI

forts

and

teem

Eúrc

a her

like

whic

but

coun

the 


\section{(439)}

The LOON is a water fowl, fomewhat lefs than a teal, and is a fpecies of the dabchick. Its wings are thort, and its legs and feet large in proportion to the body; the colour of it is a dark brown, nearly approaching to black, and as it feeds only on fifh, the flefh of it is very ill-flavoured. Thefe birds are-exceedingly numble and expert at diving, fo that it is almoft impoflible for one perfon to thoot them, as they will dextrounly avoid the thot by diving before they reach them; fo that it requires three perfons to kill one of them, and this can only be done the moment it raifes his head out of the water as it returns to the furface after diving. It however only repays the trouble taken to obtain it, by the excellent fport it affords.

The PARTRIDGE. There are three forts of partridges here, the brown, the red, and the black, the firft of which are moft-efteemed. They are all much larger than the European partridges, being nearly the fize of a hen phearant, their head and eyes are alfo like that bird, and they have all long tails, which they fpread like a fan, but not ereet; but contrary to the cuftom of thofe in other countries, they will perch on the branch of the poplar and black birch, on the buds of which 


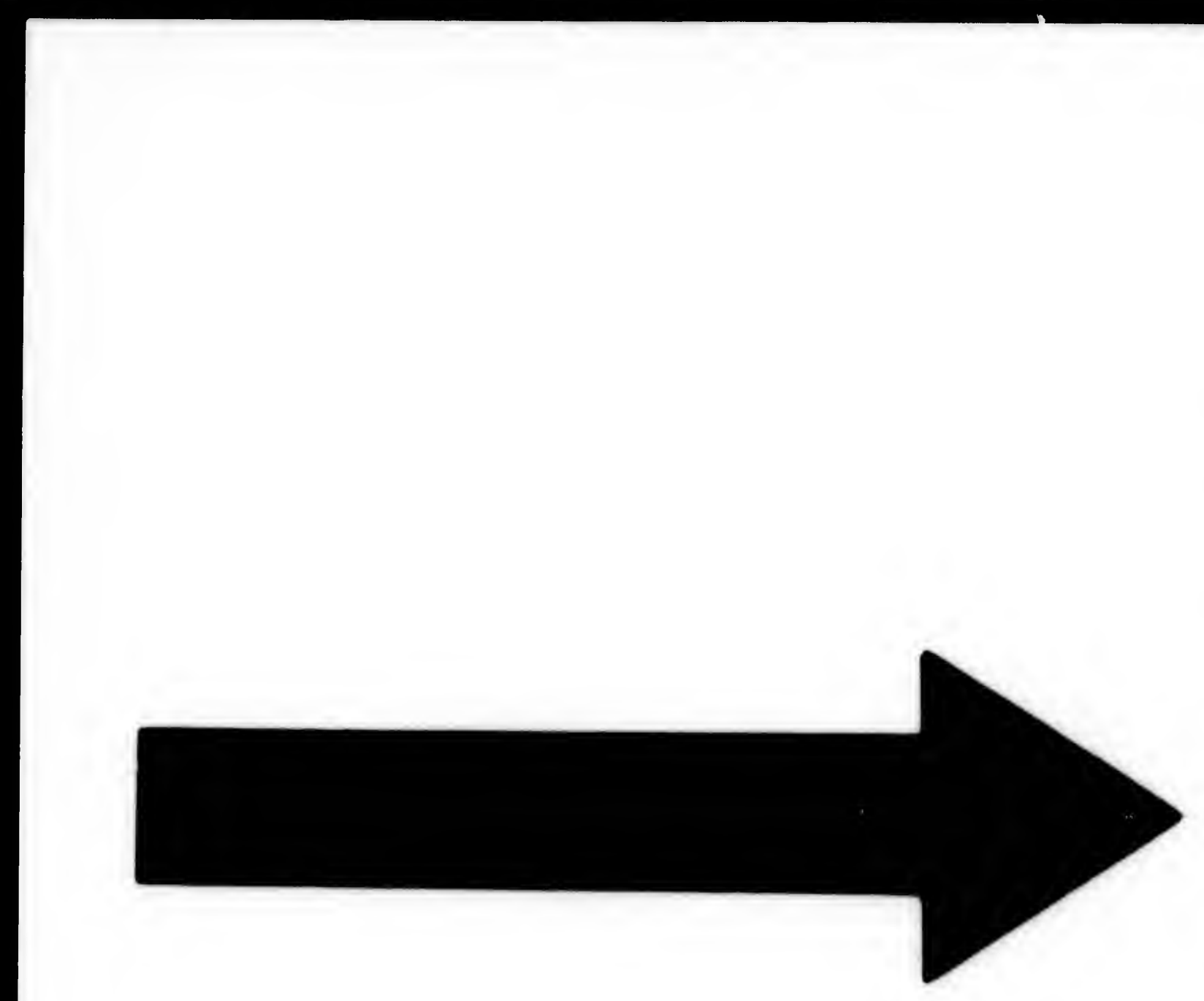




\section{IMAGE EVALUATION \\ TEST TARGET (MT-3)}
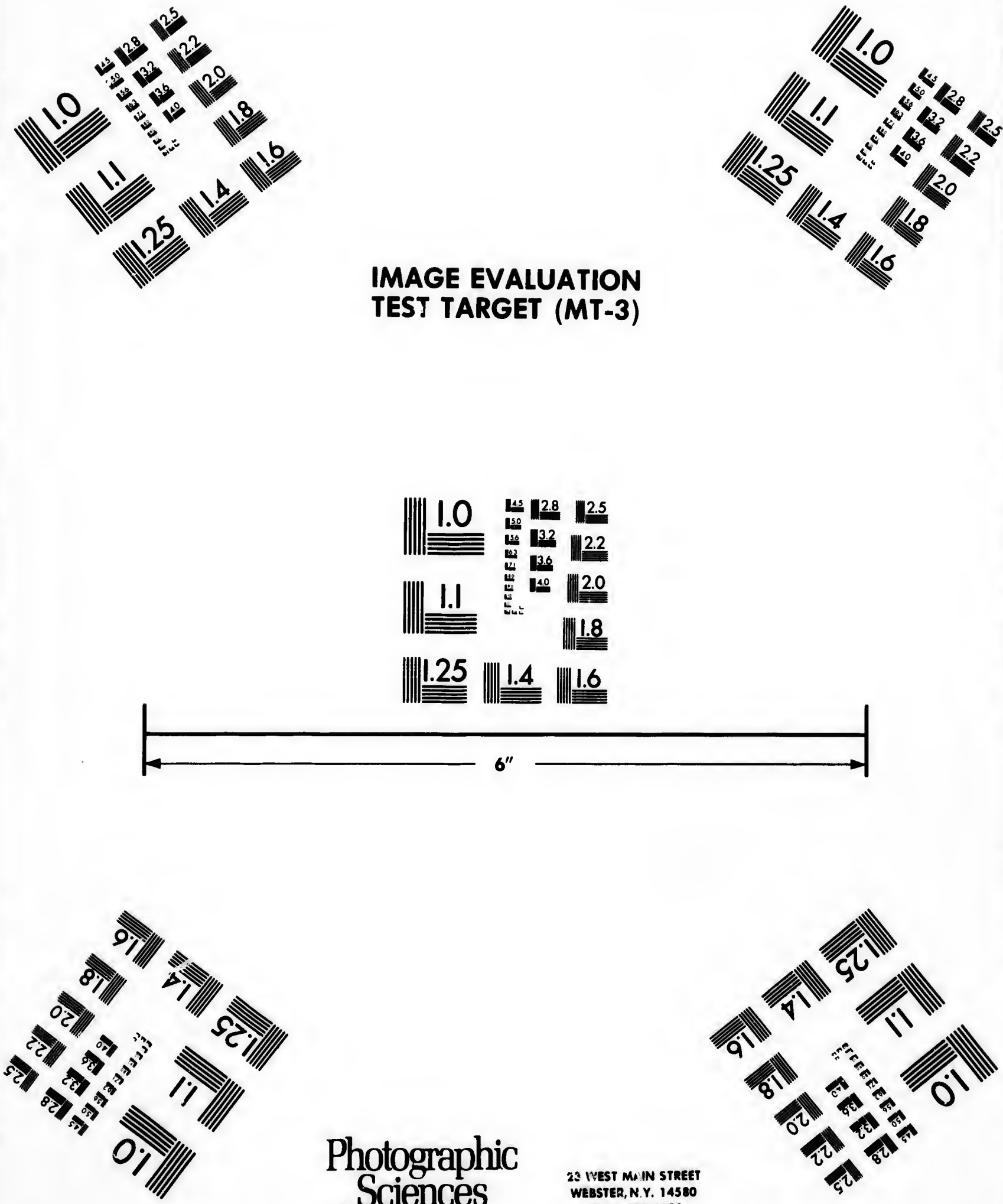

Photographic Sciences Corporation
23 WEST MU IN STREET WEBSTER, N.Y. 14580 (716) 672-4503

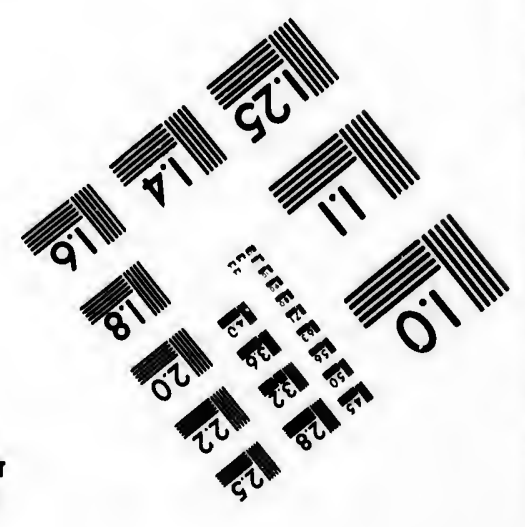





\section{( 440$)$}

which they feed early in the morning and in whe twilight of the cvening during the winter months, when they are eafily thot.

The WOODP. CKER. This is a very beautiful bird; there is one fort whofe feathers are a mixture of various colours; and another that is biown all over the body, except the bead and neck, which are of a fine red. As this bird is fuppofed to make a greater noife than ordinary at particular times, it is conjectured his cries then denote rain.

The BLUE JAY. This bird is rhaped nearly like the European jay, only that its tail is longer. On the top of its head is a creft of blue feathers, which is raifed or let down at pleafure. The lower part of the neck behind, and the back, are of a purplirh colour, and the upper fides of the wings and tail, as well as the lower part of the back and rump, are of a fine blue; the extremities. of the wings are blackin, faintly tinctured with dark blue on the edges, whilft the other parts of the wing are barred acrofs with black in an elegant manner. Upon the whole this bird can farcely be exceeded in beauty by any of the winged inhabitants of this or other climates. It has the fame jetting motion that 


\section{( 44I $)$}

jays generally have, and its cry is far more pleafing.

The WAKON BIRD, as it is termed by the Indians, appears to be of the fame fpecies as the birds of piradife. The name they have given it is exprefive of its fuperior cxcellence, and the veneration they have for it; the wakon bird being in their language the bird of the Great Spirit. It is nearly the fize of a fwalluw, of a brown colour, thaded about the neck with a bright green, the wings are of a darker brown than the body; its tail is compofed of four or five feathers, which are three times as long as its body, and which are beautifully maded with green and purple. It carries this fine length of plumage in the fume manner as a peacock does, but it is not known whether it ever railes it into the ereet pofition that bird fometimes does. I never faw any of thefe birds in the colonies, but the Naudoweflie Indians caught feveral of them when I was in their country, and feemed to treat them as if they werc of a fuperior rank to any other of the feathered race.

The BLACKBIRD. There are three forts of birds in' North-America that bear this name; the firft is the common, or as it is there termed, the crow blackbird, which is 


\section{$(442)$}

quite black, and of the fame fize and Thape of thofe in Europe, but it has not that melody in its notes which they have. In the month of September this fort fly in large flights, and do great mifchief to the Indian corn which is at that time juft ripe. The fecond fort is the red.wing, which is rather fmaller than the firft fpecies, but like that it is black all over its body, except on the lower rim of the wings, where it is of a fine bright fuli fcarlet. It builds its neft, and chiefly reforts among the fmall burhes that grow in meadows and low fwampy places. It whiftles a few notes, but is not equal in its fong to the European blackbird. The third fort is of the fame fize as the latter, and is jet black like that, but all the upper part of the wing, juft below the back, is of a fine clear white; as if nature intended to diverfify the fpecies, and to atone for the want of a melodious pipe by the beauty of its plumage; for this alfo is deficient in its mufical powers. The beaks of every fort are of a full yellow, and the females of each of a rufty black like the European.

The RED BIRD is' about the fize of a fpirrow, but with a longer tail, and is all over a bright vermillion colour. I faw many of them about the Ottawaw Lakes, but $\mathbf{I}$ 


\section{( 443 )}

could not learn that they fung. I alfo obferved in fome other part, a bird of much the fame make, that was entirely of a fine yellow.

The WHETSAW is of the cuckov kind, being like that a folitary bird, and fcarcely ever feen." In the fummer months it is heard in the groves, where it makes a noife like the filing of a faw; from which it receives its name.

The KING BIRD is like a fwallow, and feens to be of the fame fpecies as the black martin or fwift. It is called the King Bird becaufe it is able to mafter almoft every bird that flies. I have often feen it bring down a hawk.

The HUMMING BIRD. This beautiful bird, which is the fmalleft of the feathered inhabitants of the air, is about the third part the fize of a wren, and is thaped extremely like it. Its legs, which are about an inch long, appear like two fimall needles, and its body is proportionable to them. But its plumage exceeds defcription. On its head it has a fmall tuft of a jetty fhining black; the breaft of it is red, the beliy white, the backs, wings, and tail of the fineft pale green; and fmall fpecks of gold are fcattered 


\section{( 444$)$}

with inexpreffible grace over the whole : befides this an almoft imperceptible down foftens the colours, and produces the moft plearing thades. With its bill, which is of the fame dininutive fize as the other parts of its body, it extracts from the flowers a moifture which is its nourifhment; over thefe it hovers like a bee, but never lights on them, moving at the fame time its wings with fuch velocity that the motion of them is imperceptible; notwithftanding which they make a humming noife, froin whence it receives its name,

of the F I SHES which are found in the Waters of the Mififippi.

I have already given a defcription of thofe that are taken in the great lakes.

The Sturgeon, the Pout or Cat Firh, the Pike, the Carp, and the Chub.

The STURGEON. The frefh water fturgeon is thaped in no other refpect like thofe taken near the fea, except in the formation of its head and tail; which are fafhioned in the fame manner, but the body is not fo angulated,

gi

at

ne

th

pr

fle

vo

of

$\operatorname{trc}$

we

in

fin

$\mathrm{Tl}$

on

der

per

for

un

gri

an

the

$\mathrm{Ha}$

to

is

dia

tee 


\section{( 445$)$}

gulated, nor are there fo m'ny horny frales about it as on the latter. Its length is generally about two fect and an half or three feet long, but in circumference not proportionable, being a flender fith. The flerh is exceedingly delicate and finely favoured; I caught fome in the head waters of the River St. Croix, that far exceeded trout. The manner of taking them is by watching them as they lie under the banks in a clear ftream, and darting at them with a filh-fpear; for they will not take a bait. There is alfo in the Miffinippi, and there only, another fort than the fpecies I have defcribed, which is fimilar to it in every refpect, except that the upper jaw extends fourteen or fifteen inches beyond the under; this extenfive jaw which is of a grifly fubftance is three inches and half broad, and continues of that breadth, fomewhat in the Thape of an oar, to the end, which is Hat. The fledh of this filh, however, is not to be compared with the other fort, and is not fo much efteemed even by the Indians.

The CAT FISH. This fin is about eighteen inches long; of a brownifh colour and without 


\section{$(446)$}

without fcales. It has a large round head, from whence it receives its name, on different parts of which grow three or four tharp horns ahout two inches long. Its fins are alfo very bony and ftrong, and without great care will pierce the hands of thofe who take them. It weighs commonly about five or fix pounds; the flefh of it is exceffively fat and lufcious, and greatly refembles that of an cel in its flavour.

The CARP and CHUB are much the fame as thofe in England, and nearly about the fame fize.

\section{O F S E R P E N T S.}

The Rattle Snake, the Long Black Snake, the Wall or Houfe Adder, the Striped or Garter Sna' ;, the 'Water Snake, the Hiffing Snake, the Green Snake, the Thorn-tail Snake, the Speckled Snake, the Ring Snake, the Two-headed Snake.

The RATTLE SNAKE. There appear to be two fpecies of this reptile; one of which is commonly termed the Black, and the other the Yellow; and of thefe the latter is generally confidered as the largent. At

vie

arre

ple:

the

tur

tint

giv

Th

full

len

per

it

dry

their 


\section{( 447 )}

their full growth they are upwards of five feet long, and the middle part of the body at which it is of the greateft bulk, meafures about nine inches round. From that part it gradually decreafes back towards the head and the tail." The neck is proportionab!y very fmall, and the head broad and depreffed Thefe are of a light brown colour, the iris of the eye red, and all the upper part of the body brown, mixed with a ruddy yellow, and chequered with many regular lines of a deep black, gradually hading towards a gold colour. In thort, the whole of this dangerous reptile is very beautiful, and could it be viewed with lefs terror, fuch a variegated arrangement of colours would be extremely pleafing. But thefe are only to be feen in their higheft perfection at the time this creature is animated by refentment ; then every tint ruhes from its fubcutaneous recers, and gives the furface of the Akin a deeper ftain. The belly is of a palifh blue, which grows fuller as it approaches the fides, and is at length intermixed with the colour of the upper part. The rattle at its tail, from which it receives its name, is compofed of a firm, dry, callous, or horny fubftance of a light brown, 


\section{( 448$)$}

brown, and confifts of a number of cells which articulate one with another like joints; and which increafe every year and make known the age of the creature. Thefe articulations being very loofe, the included points frike againit the inner furface of the concave part or rings into which they are admitted, and as the fnake vibrates or Mhakes its tail, makes a rattling noife. This alarm it always gives when it is apprehenfive of danger; and in an inflant after forms itfelf into a fpiral wreath, in the centre of which appears the head eres, and breathing forth vengeance againft either man or beaft th-e Phall dare to come near it. In this attrunde he awaits the approach of his enemies, rattling his tail as he fees or hears them coming on. By this timely intimation, which heaven feems to have provided as a means to counteract the mifchief this venemous reptile would otherwife be the perpetrator of, the unwary traveller is apprized of his dancer, and has an opportunity of avoiding it. It is however to be obferved, that it never acts offenfively; it neither purfues or flies from any thing that approaches it, but lies in the pofition defcribed, 


\section{[ 449 ]}

defcribed, tattling his tail as if reluctant to hurt. The teeth with which this ferpent effects his poifonous purpofes are not thofe he makes ufe of on ordinary occafions, they are only two in number, very fmall and tharp pointed, and fixed in a fincwy fubftance that lies near the extremity of the upper jaw, refembling the claws of a cat; at the root of each of thefe, which might be extended; contracted, or entircly hidden, as need requires, are two finall bladder's which nature has fo conftructed, that at the fame inftant an incifion is made by the teeth, a drop of a greenith poifonous liquid enters the wound, and taints with its deftructive quality the whole mafs of blood. In a moment the unfortunate victim of its wrath: fcels a chilly tremor runs through all his frame; a fwelling immediately begins on the fpot where the teeth had entered, which fpread's by degrees over the whole body, and produces on every part of the fkin the variegated hue of the fnake. The bjte of this reptile is more or lefs venomous according to the feafon of the year in which it is given. In the dogdays, it often proves infantly mortal, and efpecially if the wound is made among the

$$
\text { G } \mathrm{g}
$$

finews 


\section{[ 450 ]}

finews fituated in the back part of the leg above the heel; but in the fpring, in autumn, or during a cool day which might happen in fummer, its bad effects are to be prevented by the immediate application of proper remedies; and thefe Providence has bounteoufly fupplied, by caufing the Rattle Snake Plantain, an approved antidote to the poifon of this creature, to grow in great profufion where-ever they are to be met with. There are likewife feveral other remedies befides this, for the venom of its bite. A decoction made of the buds or bark of the white afh taken internally prevents its pernicious effects. Salt is a newly difcovered remedy, and if applied immediately to the part, or the wound be wahned with brine, a cure might be affured. The fat of the reptile alfo rubbed on it is frequently found to be very efficacious. But though the lives of the perfons who have been bitten might be preferved by thefe, and their health in fome degree reftored, yet they annually experience a flight return of the dreadful fymptoms about the time they received the inftillation. However remarkable it may appear it is certain, that though the venom 


\section{[ $45 \mathrm{I}$ ]}

of this crcature affects in a greater or lefs de. gree allanimated nature, the hog is an exception to the rule, as that animal will readily deftroy them without treading their poifonous fangs, and fatten on their flefh. It has been often obferved, and I can confirm the obfervation, that the Rattle Snake is charmed with any harmonious founds, whether vocal or inftrumental; I have many times feen them even when they have been enraged, place themfelves in a liftening pofture, and continue immovably attentive and fufceptible of delight all the time the mufick has lafted. I Thould have remarked, that when the Rattle Snake bites, it drops its under jaw, and holding the upper jaw erect, throws itfelf in a curved line, with great force, and as quick as lightning, on the object of its refentment. "In a moment after, it returns again to its defenfive pofture, having difengaged its teeth from the wound with great celerity, by means of the pofition in which it had placed its head when it made the attack. It never extends itfelf to a greater diftance than half its length will reach, and though it fometimes repeats the blow two or three times, it as

$$
\mathrm{Gg} 2 \text { often }
$$




\section{[452]}

often returns with a fudden rebound to its former ftate. The Black Rattle Snake differs in no other refpect from the yellow, than in being rather fmaller, and in the variegation of its colours, which are exactly reverfed : one is black where the other is yellow, and vice verfa. They are equally, venomous. It is not known how thefe creatures engender ; I have often found the eggs of feveral other fpecies of the fnake, but notwithftand. ing no one has taken more pains to acquire a perfect knowledge of every property of thefe reptiles than myfelf, I never could difcover the manner in which they bring forth their young. I once killed a female that had feventy young ones in its belly, but thefe were perfectly formed, and I faw them juft before retire to the mouth of their mother, as a place of fecurity, on my approach. The gall of this ferpent, mixed with chalk, are formed into little balls, and exported from America for medicinal purpofes. They are of the nature of Gafcoign's powders, and are an excellent remedy for complaints incident to children. The fleth of the fnake alfo dried, and made into broth, is much 


\section{[ 453 ]}

more nutritive than that of vipers, and very efficacious againft confumptions.

The L O N B L A C K S N K E.

Thefe are alfo of two forts, both of which are exactly fimilar in mape and fize, only the belly of one is a light red, the other a faint blue; all the upper parts of their bodies are black and fcaly. They are in general from fix to eight fect in length, and carry their heads, as they crawl along, about a foot and half from the ground. They eafily climb the higheft trees in purfuit of birds and fquirrels, which are their chief food; and the fe, it is faid, they charm by their looks, and render incapable of efcaping from them. Their appearance carries terror with it to thofe who are unacquainted with their inability to hurt, but they are porfectly inoffenfive and free from venom.

The STRIPED or GARTER SNAKE, is exactly the fame as that fpecies found in other climates.

The WATER SNA KE is much like the Rattle Snake in Mape and fize, but is not endowed with the farne venomous powers, being quite harmlefs.

The 


\section{[ 454 ]}

The HISS I NG S A K E I have already particularly defcribed, when I treated, in my Journal, of Lake Erie.

The GREEN SN A KE is about a foot and half long, and in colour fo near to grafs and herbs, that it cannot be difcovered as it lies on the ground; happily, however it is free from venom, otherwife it would do an infinite deal of mifchief, as thofe who pafs through the meadows, not being able to perceive it, are deprived of the power of avoiding it.

The T HOR N-T A I L S N A K E. This reptile is found in many parts of America, but is very feldom to be feen. It is of a middle-fize, and receives its name from a thorn-like dart in its tail, with which it is faid to inflict a mortal wound.

The S P E C K LE D S A K E is an aqueous reptile about two feet and half in length, but without venom. Its $\mathrm{k}$ kin, which is brown and white with fome fpots of yellow in it, is ufed by the Americans as a cover for the handles of whips, and it renders them very pleafing to the fight.

The RING SNAKE is about twelve inches long; the body of it is entirely black, 


\section{[ 455 ] "}

black, except a yellow ring which it has about its neck, and which appears like a narrow piece of riband tied around it. This odd reptile is frequently found in the bark of trees, and among old logs.

The T W O-HEADED SNAKE. The only fnake of this kind that was ever feen in America, was found about the year 1762, near Lake Champlain, by Mr. Park, a gentleman of New England, and made a prefent to Lord Amherft. It was about a foot long, and in thape like the common fnake, but it was furnifhed with two heads exactly fimilar, which united at the neck. Whether this was a diftinct fpecies of fnakes, and was able to propagate its likenefs, or whether it was an accidental formation, I know not.

The TORTOISE or LAND T URTLE. The Thape of this creature is fo well known that it is unneceffary to defcribe it. There are feven or eight forts of them in America, fome of which are beautifully variegated, even beyond defcription. The mells of many have fpots of red, green, add yellow in them, and the shequer work is compofed of fmall fquares, curioully 


\section{$\left[\begin{array}{lll}456 & \end{array}\right]$}

curioufly difpofed. The mof beautiful fort of thefe creatures are the frnallef, and the bite of them is faid to be venomous.

\section{I Z A R D S, \&c.}

Though there are numerous kinds of this clars of the animal creation in the country I trat of, I hall only take notice of two of them, which are termed the Swift and Slow Lizard.

The SWIFT LIZARD is about fix inches long, and has four legs and a tail. Its body, which is blue, is prettily friped with dark lines Maded with yellow; but the end of the tail is totally blue. It is fo remarkably agile that in an inftant it is out of fight, nor can its movement be perceived by the quickeft .eye : fo that it might more jufly be faid to vanith, than to run away. This fpecies are fuppofed to poifon thofe they bite; but are not dangerous, as they never attack perfons that approach them, chufing rather to get fuddenly out of their reach.

The SLOW LIZARD is of the fame Thape as the Swift, but its colour is brown; 


\section{[ 4557 ]}

it is moreover of an oppofite difpofition, being altogether as now in its movements as the other is fwift. It is remarkable that thefe lizands are extremely brittle, and will break off near the tail as eafily as an icicle.

Among the reptiles of North America there is a fpecies of the toad termed the TREE TOAD, which is nearly of the fame thape as the commor fort, but fmaller and with longer claws. It is ufually found on trees, fticking clofe to the bark, or hying in the crevices of it, and fo nearly does it refemble the colour of the trees to which it cleaves, that it can with difficulty be diftinguinhed from it. Thefe creatures are only heard during the twilight of the morning and evening, or juft before and after a hower of rain, when they make a croaking noife fomewhat hriller than that of a frog, which might be heard to a great diftance. They infelt the woods in fuch numbers, that their refponfive notes at thefe times make the air refound. It is only a fummer animal, never to be found during the winter. 


\section{$\left[\begin{array}{ll}458 & \end{array}\right]$ \\ I N S E C T S.}

The interior parts of North America abound with nearly the fame infects as are met with in the fame parallels of latitude; and the fpecies of them are fo numerous and diverfified, that even a fuccinct defcription of the whole of them would fill a volume; I Shall therefore confine myfelf to three forts, which I believe are almoft peculiar to this country; the Lightning Bug, the Water Bug, and the Horned Bug.

The LIGHTNING BUG or FIRE FLY is about the fize of a bee, but it is of the beetle kind, having like that infect two pair of wings, the upper of which,are of a nirm texturc, to defend it from danger. When it flies, and the wings are expanded, there is under thefe a kind of coat, conftructed alfo like wings, which is luminous ; and as the infect paffes on, caufes all the hinder part of fits body to appear like a bright fiery coal. Having placed one of them on your hand, the under part only fhines, and throws the light on the fpace beneath; but as foon as 


\section{[ 459 ]}

it fpreads its upper wings to fly away, the whole body - which lies behind them appears illuminated all around. The light it gives is not conftantly of the fame magnituaie, even when it flies; but feems to depend on the expanfion or contraction of the luminous coat or wings ; and is very different from that emitted in a dark night by dry wood or fome kinds of filh, it having much more the appearance of real fire. They feem to be fenfible of the power they are poffeffed of; and to know the mont fuitable time for exerting it, as in a very dark night they are much more numerous than at any other time. They are only feen during the fummer months, June, July, and Auguf, and then at no other time but in the night. Whether from their colour, which is a dunky brown, they are not then difcernable, or from their retiring to holes and crevices, -1 know not, but they are never to be difcovered in the day. They chiefly are feen in low fwampy land, and appear like innumerable tranfient gleams of light. In dark nights when there is much lightning, without rain, they feem as if they wifhed cither to imitate or affift the 


\section{[ 460 ]}

the flathes; for during the intervals, they are uncommonly agile and endeavour to throw out every ray they can collect. Notwithftanding this effulgent: appearance, thefe infects are perfectly harmlefs; you may permit them to crawl upon your hand, when five or fix, if they freely exhibit their glow together, will enable you to read almoft the fmalleft print.

The WATER BUG is of a brown colour, about the fize of a pea, and in thape nearly oval: it has many legs, by means of which it paffes over the furface of the water with fuch incredible fwiftnefs, that it feems to nide or dart itfelf along.

The HORNED BUG, or as it is fometimes termed the STAG BEETLE, is of a duiky brown colour nearly approaching to black, about an inch and half long, and half an inch broad. It has two large horns, which grow on each fide of the head, and meet horizontally, and with thefe it pinches very hard; they are branched like thofe of a ftag, from whence it - receives its name. They fly about in the evening, and prove very troublefome to thore who are in the fields at that time.

I muft

of

1

cha!

the inte lari: of hav 


\section{[ 46r.]}

I muft not omit that the LOCUST is a) feptennial infect, as they are only feen, a fmall number of Atragglers excepted, every feven years, when they infeft thefe parts, and the interior colonies in large fwarms, and do a great deal of mifchief. The years when they thus arrive are denominated the locuft years.

\section{H A P. XIX.}

Of the Trees, SHRubs, Roots, Her Bs, Flowers, Esc.

SHALL here obferve the fame method
that I have purfued in the preceding chapter, and having given a lift of the trees, \&c. which are natives of the interior parts of North America, particuIarize fuch only as differ from the produce of other countries, or being little known, have not been defcribed.

\section{OF T R E E S.}

The Oak, the Pine Tree, the Maple, the Ath, the Hemlock, the Bafs or White Wood, 


\section{[. 462 ]}

Wood, the Cedar, "the Elm, the Birch, the Fir, the Locuft Tree, the Poplar, the Wickopic or Suckwic, the Spruce, the Hornbeam, and the Button Wood Tree.

The OAK. There are feveral forts of oaks in thefe parts; the black, the white, the red, the yellow, the grey, the fwamp. oak, and the chefnut oak : the five former vary but little in their external appearance, the Ihape of the leaves and the colour of the bark being fo much alike, that they are fcarcely diftinguifhable ; but the body of the tree when fawed difcovers the variation, which chiefly confifts in the colour of the wood, they being all very hard and proper for building. The fwamp oak differs materially from the others both in the thape of the leaf, which is fmaller, and in the bark, which is fmoother; and likewife as it grows only in a moift gravelly foil. It is efteemed the tougheft of all woods, being fo ftrong yet pliable, that it is often made ufe of inftead of whalebone, and is equally ferviceable. "The chefnut oak alfo is greatly different from the others, particularly in the Thape of the leaf, which much refembles

that 


\section{( 463$)$}

that of the chefnut tree; and for this reafon it is fo denominated. It is neither fo ftrong as the former fpecies, or fo tough as the latter; but is of a nature proper to be fplit into rails for fences, in which ftate it will endure a confiderable time.:

The PINE TREE. That fpecies of the pine tree peculiar to this part of the continent is the white, the quality of which I need not defcribe, $i$ as the timber of it is fo well known under the name of deals.: It grows here in great plenty, to an amazing height and fize; and yields an excellent turpentine, though not in fuch quantities as thofe in the northern parts of Europe.

THE MAPLE. Of this tree there are two forts, the hard and the foft, both of which yield a lufcious juice, from which the Indians by boiling make very good fugar. The fap of the former is much richer and fweeter than the latter, but the foft produces a greater quantity. The wood of the hard maple is very beautifully veined and curled, and when wrought into cabinets, tables, gunftocks, \&c. is greatly valued. That of the foft fort differs in its texture, wanting the variegated 


\section{[ 46.4 ]}

-variegated grain of the hard; it alfo growe more Atrait and free from branches, and is Inore eafily fplit. It likewife may be diftinguifhed from the hard, as this grows in meadows and low-lands, that on the hill and up-lands. The leaves are thaped alike, but thofe of the foft maple are much the targeft, and of a deeper green:

The ASH. There are feveral forts of

- this tree, in thefe parts; but that to which 1 thall confine my defcription; is the yellow an, which is only found near the head branches of the Miffifippi. This tree gtows to an amazing height, and the body of it is fo firm and found, that the French traders who go into that country from Louifiana to purchafe furs make of them periaguays; this they do by excavating then with fire, and when they ate completed, convey in them the produce of their trade to New Orleans, where they find a good market both for their vefiels and cargoes. "The wood of this tree greatly refembles that of the common alh, but it might be diftinguined from 


\section{( 405$)$}

any other tree by its bark; the rofs or outfide bark being near eight inches thick, and in'dented with furrows more than fix inches deep, which make thofe that are arrived to a great bulk appear uncommonly rough; and by this peculiarity they may be readily known. The rind or infide batk is of the fatine thicknefs as that of other trecs, but its colour is a fin: bright yellow; infomuch that if it is but flightly handled, it will leave a ftain on the fingers, which cannot eafily be wahed away; and if in the fpring you peel off the bark, and touch the fap, which then rifes between that and the body of the tree, it will leave fo deep a tincture that it will require three or four days to wear it off. Many ufeful qualities belonging to this tree I doubt not will be difcovered in time, befides its proving a valuable acquifition to the dyer.

The HEMLOCK TREE grows in every part of America in a greater or lefs degree. It is an ever-green of a very large growth, and has leaves fomewhat like that of the yew; it is however quite ufelefs, and only an incumbrance to the ground, the wood being of a very coarfe grain, and full of wind-hakes or cracks. 


\section{(466)}

- The BASS or WHITE WOOD is a treo of a middling fize, and the whiteft and fofteft wood that grows, when quite dry it fwims on the water like a cork ; in the fettlements the turners make of it bowls, trenchers and difhes, and will lait a long time; but when applied to any other purpofe it is far from durable.

The WICKOPICK or SUCKWICK appears to be a fpecies of the white wood, and is diftinguifhed from it by a peculiar quality in the bark, which when pounded and moiftened with a little water, inftantly becomes a matter of the confiftence and nature of fize. With this the Indians pay their canues, and it greatly exceeds pitch or any other material ufually appropriated to that purpofe ; for befides its adhefive quality, it is of fo oily a nature, that the water cannot penetrate throush it, and its repelling power abates not for a confiderabic time.

The BUTTON! WOOD is a tree of the largeft fize, and might be diftinguifhed by its bark, which is quite fmooth and prettily mottled. The wood is very proper for the ufe of cabinet-makers. It is covered with fmall hard burs which fpring from the branch- 


\section{$(467)$}

es, that appear not unlike buttons, and from thefe I believe it receives its name.

\section{N U T T R E E S.}

The Butter or Oilnut, the Walnut, the Hazlenut, the Beechnut, the Pecannet; che Chefnut, the Hickory.

The BUT'TER or OILNUT. As no mention has been made by any authors of this nut, I thall be the more particular in my account of it. The tree grows in meadows, where the foil is rich and warm. The body of it feldom exceeds a yard in circumference, is full of branches, the twigs of which are hort and blunt, and its leaves re-femble thofe of the walnut. The nut has a fhell like that fruit, which when ripe is more furrowed, and more eafily cracked ; it is alfo much longer and larger than a walnut, and contains a greater quantity of kernel, which is very oily, and of a rich agreeable flavour. I am perfuaded that a much purer oil than that of olives, might be extracted from this nut. The infide bark of this tree dyes $\mathbf{a}$ good purple; and it is faid, varies in its 


\section{( 468$)$}

Thade, being either darker or lighter according to the month in which it is gathered.

The BEECH NUT. 'Though this, tree grows exactly like that of the fame name in Europe, yet it produces nuts equally as good as chefnuts; on which bears, martins, fquirrels, partridges, turkies, and many other beafts and birds feed. The nut is contained, whilft growing, in an outfide cafe like that of a chefnut, but not fo prickly; and the coat of the infide thell is alfo fmooth like that; only its form is nearly triangular. Vaft quantities of them lie fcattered about in the woods, and fupply with food great numbers of the creatures juft mentioned. The leaves, which are white, continue on the trees during the whole winter. A decoction made of them is a certain and expeditious cure for wounds which arife from burning or fcalding, as well as a reftorative for thofe members that are nipped by the fref.

The PECANNUT is fomewhat of the walnut kind, but rather fmaller than a walnut, being about the fize of a middling acorn, and of an oval form; the thell is eafily cracked, and the kcrnel haped like that of a walnut. 


\section{(469)}

walnut. This tree grows chiefly near the II. linois river.

The HICKORY is alfo of the walnut kind, and bears a fruit nearly like that tree. There are feveral forts of them, which vary only in the colour of the wood. Being of a very tough nature, the wood is generally ufed for the handles of axes, \&c. It is alfo very good fire wood, and as it burns an excellent fugar diftills from it.

\section{F R U I T T R E E S.}

- I need not obferve that thefe are all the fpontaneous productions of nature, which have never received the advantages of ingrafting, tranfplanting, or manuring.

The crab apple-tree, the plum-tree, and the cherry-tree.

The CRAB APPLE TREE bears a fruit that is much larger and better flavoured than thofe of Europe.

The PLUM-TREE. There are two forts of plums in this country, one a large fort of a purple caft on one fide, and red on the reverfe, the fecond totally green, and much fmaller. Both thefe are of a good flavour, 


\section{( 470$)$}

flavour, and are greatly efteemed by the Indians, whofe tafte is not refined, but who are fatisfied with the productions of nature in their unimproved ftate.

The CHERRY-TREE. There are three forts of cherries in this country, the black, the red, and the fand cherry; the two latter may with fome propriety be ranked among the Thrubs, as the buith that bears the fand cherries almoft creeps along the ground, and the other rifes not above eight or ten feet in height; however I thall give an account of them all in this place. The black cherries are about the fize of a currant, and hang in clufters like grapes; the trees which bear them being very fruitful, they are generally loaded, but the fruit is not good to eat, however they give an agreeable flavour to brandy, and turn it to the colour of claret. The red cherries grow in the greateft profufion, and hang in bunches like the black fort juft defcribed; fo that the bufhes which bear them appear at a diftance like folid bodies of red matter. Some people admire this fruit, but they partake of the nature and tafte of allum, leaving a difagreeable roughnefs in the throat, and being 


\section{(47I)}

very aftringent. As I have already defcribed the fand cherries, which greatly exceed the two other forts both in flavour and fize, I Thall give no further defcription of them. The wood of the black cherry-tree is very ufeful, and works well into cabinet-ware.

\section{S H R.U B S.}

The Willow, Shin Wood, Shumack, Saffafras, the Prickly Afh, Moofe Wood, Spoon Wood, Large Elder, Dwarf Elder, Poifonous Elder, Juniper, Shrub Oak, Sweet Fern, the Laurel, the Witch Hazle, the Myrtle, Winter Green, the Fever Bum, the Cranberry Burh, the Goofberry Burh, the Currant Burh, the Whirtle Berry, the Ranberry, the Black Berry, and the Choak Berry.

The WILLOW. There are feveral fpecies of the willow, the moft remarkable. of which is a fmall fort that grows on the banks of the Miffiflippi, and fome other places adjacent. The bark of this thrub fupplies the beaver with its winter food; and where the water has wanhed the foil from its roots, they appear to confift of fibres interwoven together like thread, the colour of which is of an inexpreffibly 


\section{( 472$)$}

expreffibly fine fcarlet; with this the Indians tinge many of the ornamental parts of their drefs.

SHIN WOOD. This extraordinary fhrub graws in the forefts, and rifing like a vine, runs near the ground for fix or eight feet, and then takes root again; in the fame manner taking root, and fpringing up fucceffively, one ftalk covers a large fpace; this proves very troublefome to the hafty traveller, by ftriking againt his thins, and entangling his legs; from which it has acquired its name.

The SASSAFRAS is a wood well known for its medicinal qualities. It might with equal propriety be termed a tree as a Mrub, as it fometimes grows thirty feet high; but in general it does not reach higher than thofe of the thrub lind. 'The leaves, which yield an agreeable fragance, are large and nearly feparated into three divifions. It bears a reddịh brown berry of the fize and thape of Pimenta, and which is fometimes ufed in the colonies as a fubftitute for that fpice. The bark or roots of this tree is infinitely fuperior to the wood for its ufe in medicine, and I am furprized it is fo feldom to be met with, as its efficacy is fo much greater. 


\section{( 473$)$}

The PRICKLY ASH is a fhrub that fometimes grows to the height of ten or fifteen feet, and has a leaf exactly refembling that of an an, but it receives the epithet to its name from the abundance of fhort thorns with which every branch is covered, and which renders it very troublefome to thofe who pafs through the fpot where they grow thick. It alfo bears a fcarlet berry, which. when ripe, has a fiery tafte like pepper. The bark of this tree, particularly the bark of the roots, is highly efteemed by the natives for its medicinal qualities. I have already mentioned one inftance of its efficacy, and there is no doubt but that the decoction of it will expeditiouny and radically remove all impurities of the blood.

The MOOSE WOOD grows about four feet high, and is very full of branches; but what renders it worth notice is its bark, which is of fo ftrong and pliable a texture, that being peeled off any feafon, and twilted, makes equally as good cordage as hemp.

The SPOON WOOD is a fpecies of the laurel, and the wood when fawed refembles box wood.

The 


\section{( 474$)$.}

The ALDER or ELDER, termed the poifonous elder, ncarly refembles the other forts in its leaves and branches, but it grows much ftraiter, and is only found in fwamps and moift foils. This thrub is endowed with a very extraordinary quality, that renders it poifonous to fome conftitutions, which it effects if the perfon only approaches within a few yards of it, whilft others may even chew the leaves or the rind without receiving the leaft detriment from them : the poifon however is not mortal, though it operates very violently on the infected perfon, whofe body and head fwell to an amazing fize, and are covered with eruptions, that at their height refemble the confluent fmall-pox. As it grows alfo in many of the provinces, the inhabitants cure its venom by drinking faffron tea, and anointing the external parts with a mixture compofed of cream and marfh mallows.

The SHRUB OAK is exactly fimilar to the oak tree, both in its wood and leaves, and. like that it bears an acorn; but it never rifes from the ground above four or five feet, growing crooked and knotty. It is found chiefly on a dry gravelly foil. 


\section{(475)}

The WI'TCH HAZLE grows very buthy, about ten feet high, and is covered early in May with numerous white bloffoms. When this fhrub is in bloom, the Indians efteem it a further indication that the froft is entirely gone, and that they might fow their corn. It has been fald, that it is poffeffed of the power of attracting gold or filver, and that twigs of it are made ufe of to difcover where the veins of thefe metals lie hid; but $I$ am apprehenfive that this is only a fallacious ftory, and not to be depended on; however that fuppofition has given it the name of witch hazle.

The MYRTLE is a fhrub about four or five feet high, the leaves of which are larger than thofe of the common myrtle, but they fmell exactly alike. It bears fmall berries, which are generally called Bay Berries, and thefe are full of a gluey fubftance, which being boiled in water, fwims on the furface of it; and becomes a kind of green wax; this is not fo valuable as bees-wax; being of a more brittle nature, but mixed with it makes a good candle, which as it burns fends forth an agreeable fcent. 


\section{( 476$)$}

WINTER GREEN. This is an ever-green of the fpecies of the myrtle, and is found on dry heaths; the flowers of it are white, and in the form of a rofe, but not larger than a filver penny; in the winter it is full of red berries about the fize of a floe, which are finooth and round; thefe are preferved during the fevere feafon by the fnow, and are at that time in the higheft perfection. The Indians eat thefe berries, efteeming them very balfamic, and invigorating to the ftomach. The people inhabiting the interior colonies fteep both the fprings and berries in beer, and ufe it as a diet-drink for cleanfing the blood from fcorbutick diforders,

The FEVER BUSH grows about five or fix feet high; its leaf is like that of a lilach, and it bears a reddinh berry of a fpicy flavour. The ftalks of it are exceffively brittle. A decoction of the buds or wood is an excellent febrifuge, and from this valuable property it receives its name. It is an ancient Indian remedy for all inflammatory complaints, and likewife much efteemed on the fame account by the inhabitants of the interior parts of the colonies. 


\section{( 477 )}

The CRANBERRY BUSH. Though the fruit of this burh greatly refembles in fize and appearance that of the common fort, which grows on a fmall vine in moraffes and bogs, yet the bufh runs to the height of ten or twelve feet; but it is very rarcly to be met with. As the meadow cranberry, being of a local growth, and flourithing only in moraffes, cannot be tranfplanted or cultivated, the former, if removed at a proper feafon, would be a valuable acquifition to the garden, and with proper nurture prove equally as good, if not better.

The CHOAK BERRY. The Thrub thus termed by the natives grows about five or fix feet high, and bears a berry about the fize of a floe, of a jet black, which contains feveral fmall feeds swithin the pulp. The juice of this fruit, though not of a difagreeable flavour, is extremely tart, and leaves a roughnefs in the mouth and throat when eaten, that has gained it the name of choak berry.

$$
\text { ROOTS and PLANTS. }
$$

Elecampane, Spikenard, Angelica, Sarfapatilla, Ginfang, Ground Nuts, wild Potatoes, Liquorice, 


\section{$(478)$}

Liqurice, Snake Root, Gold Thread, Solomon's Seal, Devil's Bit, Blood Root, Onions, Garlick, Wild Parfnips, Mandrakes, Hellebore White and Black.

SPIKENARD, vulgarly called in the colonies Petty-Morrell. Thus plant appears to be cxaclly the fame as the Afiatick fpikenard, fo much valucd by the ancients. It grows near the fides of biooks in rocky places, and its ftem, which is about the fize of a goofe quill, fprings up like that of angelica, reaching about a foot and a half from the ground. It bears bunches of berries in all refpects like thofe of the elder, only rather larger. Thefe are of fuch a balfamic nature, that when infufed in fpirits, they make a moft palatable and reviving cordial.

SARSAPARILLA. The root of this plant, which is the moft eftimable part of it, is about the fize of a goofe quill, and runs in different directions, twined and crooked, to a great length in the ground; from the principal ftem of it fpring many fmaller fibres, all of which are tough and flexible. From the root immediately fhoots a falk about a foot and a halflong, which at the top branches into three frems; each of thefe inas three 


\section{( 479 )}

leaves, much of the Thape and fize of a walrut leaf, and from the fork of each of the three ftems grows a bunch of bluilh white flowers, refembling thofe of the fpikenard. The bark of the roots, which alone fhould be ufed in medicine, is of a bitterifh flavour, but aromatic. It is defervedly efteemed for its medicinal virtues, being a gentle fudorific, and very powerful in attenuating the blood when impeded by grofs humours.

GINSANG is a root that was once fuppofed to grow only in Korea, from whence. it was ufually exported to Japan, and by that means found its way to Europe; but it has lately been difcovered to be alfo a native of North America, where it grows to as great perfection and is equally valuable. Its root is like a finall carrot, but not fo taper at the end; it is fometimes divided into two or more branches, in all other refpects it refembles farfaparilla in its growth. The tafte of the root is bitterifh. In the eaftern parts of Afia it bears a great price, being there confidered as a panacea, and is the laft refuge of the inhabita:ts in all diforders. When chewed it certainly is a great ftrengthener of the ftomach. 


\section{( 480$)$}

GOLD THREAD. This is a plant of the fmall vine kind, which grows in fwampy places, and lies on the ground. The roots fpread themfelves juft under the furface of the morafs, and are eafily drawn up by handfuls. They refemble a large entangled tkain of thread of a fine bright gold colour; and I am perfuaded would yield a beautiful and permanent yellow dye. It is alfo greatly ef: teemed both by the Indians and culcnifts as a remedy for any forenefs in the mouth, but the tafte of it is exquifitely bitter.

SOLOMON's SEAL is a plant that grows on the fides of rivers, and in rich meadcw land. It rifes in the whole to about three feet high, the ftalks being two feet, when the leaves begin to fpread themfelves and reach a foot further. Every fibre of the root has an imprefion upon it about the fize of a fixpence, which appears as if it was made by a feal, and from thefe it receives its name. It is greatly valued on account of its being a fine purifier of the blood.

DEVIL's BIT is another wild plant, which grows in the fields, and receives its name from a print that feeins to be made by teeth in the roois. The Indians fay that this was

Sar

$\mathrm{M}:$

No

$\mathrm{Gr}$

We

W:

Wi

Cat once 


\section{(. $48 \mathrm{I})$}

once an univerfal remedy for every diforder that human nature is incident to; but fome of the evil fpirits envying mankind the porfeffion of fo efficacious a medicine, gave the root a bite, which deprived it of a great part. of its virtues.

BLOOD ROOT. A fort of plantain that fprings out of the ground in fix or feven long rough leaves, the veins of which are red; the root of it is like a fmall carrot both in colour and appearance; when broken, the infide of it is a deeper colour than the outfide, and diftils feveral drops of juice that look like blood. This is a ftrong emetic, but a very dangerous one.

\section{H E R B S.}

Balm, Nrittles, Cinque Foil, Eyebright, Sanicle, Piantain, Poor Robin's Plantain, Maiden Hair, Wild Dock, Rock Liverwort, Noble Liverwort, Bloodwort, Wild Beans, Ground Ivy, Water Creffes, Yarrow, May Weed, Gargit, Skunk Cabbage or Poke, Wake Robin, Betony, Scabious, Mullen, Wild Peafe, Moufe Ear, Wild Indigo, and Cat Mint. 


\section{$(482)$}

SANICLE has a root which is thick towards the upper part, and full of fmall fibes below; the leaves of it are broad, roundin, hard, finooth, and of a fine thining green; a ftalk rifes from thefe to the height of a foot; which is quite fmooth and free from knots, and on the top of it are feveral fmall flowers of a reddifh white, Shaped like a wild rofe. A tea made of the root is vulnerary and balfe. mick.

RATTLE SNAKE PLANTAIN, This ufeful herb is of the plantain kind, and its leaves, which fpread themfelves on the ground, are about one inch and half wide, and five inches long; from the centre of thefe arifes a fmall ftalk nearly fix inches long, which bears a little white flower; $t^{2}$ e root is about the fize of a goofe quil!, and much bent and divided into feveral branches. The leaves of this herb are more efficacious than any other part of it for the bite of the reptile from which it receives its name; and being chewed and applied ipnmediately to the wound, and fome of the juice swallowed, feldom fails of averting every dangerous fymptom. So convin ed are the Indians of the power of this infallisle antidote, that for a trifling bribe of fpirituous li-

quor, 


\section{(. 483$)$.}

quor, they will at any time permit a rattle fnake to drive his fangs into their flerh. It is to be remarked that during thofe months in which the bite of thefe creatures is moft venomous, that this remedy for it is in its greateft perfection, ard thoft luxuriant in its growth.

POOR ROBIN's PLANTAIN is of the fume fpecies as the laft, but more diminutive in every refpect; it receives its name from its fize, and the poor land on which it grows. It is a good medicinal herb, and often adminiftered with fuccefs in fevers and internal weakneffes."

TOAD PLANTAIN refembles the common plantain, only it gtows mnch ranker, and is thus denominated becaufe toads love to harbour under it.

ROCK LIVERWORT is a fort of liverwort that grows on rocks, and is of the nature of kelp or mofs. It is efteemed as an excellent rơnedy againft declines.

GARGIT or SKOKE is a large kind of wced, the leaves of which are about fix inches fong, and two inches and half broad; they refemble thofe of fpinage in their colour and texture, but not in flape. The root 


\section{( 484$)$}

is very large, from which fpring different ftalks that run eight or ten feet high, and are full of red berries; thefe hang in clufters in the month of September, and are generally called pigeon berries, as thofe birds then feed on them. When the leaves firft fpring from the ground, after being boiled, they are a nutritious and wholefome vegetable, but when they are grown nearly to their full fize, they acquire a poifonous quality. The roots applied to the hands and s. $\therefore$ of a perfon afflicted with a fever, prove a very powerful abforbent.

SKUNK CABBAGE or POKE is an herb that grows in moift and fwampy places. The leaves of it are about a foot long and fix inches broad, nearly oval, but rather pointed. The ronts are compofed of great numbers of fibres, a lotion of which is made ufe of by the people in the colonies for the cure of the itch. There iffues a frong mufky fmell from this herb, fomething like the animal of the fame name before defcribed, and on that account it is fo termed.

WAKE ROBIN is an herb that grows in fwampy lands; its root refeinbles a fmall turnip, and if tafted will greatly inflame the tongue, 


\section{(485)}

tongue, and immediately convert it from its natural thape, into a round hard fubfance; in which ftate it will continue for fome time, and during this no other part of the mouth will be affected. But when dried, it lofes its aftringent quality, and becomes beneficial to mankind, for if grated into cold water, and taken internally, it is very good for all complaints of the bowels.

WILD INDIGO is an herb of the fame fpecies as that from whence Indigo is made in the fouthern colonies. It grows in one ftalk to the height of five or fix inches from the ground, when it divides into many branches, from which iffue a great number of fmall hard bluifh leaves, that fpread to a great breadth, and among thefe it bears a yellow flower; the juice of it has a very difagreeable fcent.

CAT MINT has a woody root, divided into feveral branches, and it fends forth a ftalk about three feet high; the leaves are like thofe of the nettle or betony, and they have a ftrong fmell of mint, with a biting acrid tafte; the flowers grow on the tops of the branches, and are of a faint purple or whitifh colour. It is called cat mint, becaufe 


\section{(486) .}

it is faid, thet cats have an antipathy to it, and will not let it grow. It has nearly the virtues of common mint.

\section{F L O W R S.}

Heart's Eafe, Lilies red and yedlow, Pond Inlies, Cownips, May Flowers, Jeffamine, Honeyfuckles, Rock Honeyfuckles, Rofes red and white, Wild Hollyhock, Wild Pinks, Golden Rod.

I Thall not enter into a minute defcription of the flowers above-recited, but only juft obferve, that they much refemble thofe of the fame name which grow in Europe, and are as beautiful in colour, and as perfect in odour, as they can be fuppofed to be in their. wild uncultivated ftate.

\section{FARINACEOUS and LEGUMINOUS ROOTS, \&c.}

Maize or Indian Corn, Wild Rice, Beans, the Squaph, \&c. 


\section{( 487$)$}

MAIZE or INDIAN CORN groivs to the height of about five or fix feet, on a ftalk full of joints, which is ftiff and folid, and when green, abounding with a fweet juice. The leaves are like thofe of the reed, about two feet in length, and three or four inches broad. The flowers which are produced at fome diftance from the fruit on the farre plant, grow like the earb of oats, and are fometirnes white, yellow, or of a purple colour.' The feeds are as large as peas, and like them quite naked and fmooth, but of a roundifh furface, rather compreffed. One fpike zenerally confifts of about fix hundred grains, which are placed clofely together in rows to the number of eight or ten, and fometimes twelve. This corn is very wholefome, eafy of digeftion, and yields as good nourihment as any other fort. After the Indians have reduced it into meal by pounding it, they make cakes of it and balke them before the fire. I have already trentioned that fome nations eat it in cales before it is tipe, in which ftate it is very.agreeabble to the palate and extremely nutritive.

WILD RICE. This grain, which grows in the greateft plenty throughout the interiot parts of North America, is the mott valuable 


\section{(488)}

luable of all the fpontaneous productions of that country. Exclufive of its utility; as a fupply of food for thofe of the human fpecies who inhabit this part of the continent, and obtained without any other trouble than that of gathering it in, the fweetners and nutritious quality of it attracts an infinite number of wild fowl of every kind, which flock from diftant climes to enjoy this rare repaft; and by it become inexpreffibly fat and delicious, In future periods it will be of great fervice to the infant colonies, as it will afford them a prefent fupport, until in the courfe of cultivation other fupplies may be produced; whereas in thofe realms which are not furnifhed with this bounteous gift of nature, even if the climate is temperate and the foil good, the firft fettlers are often expofed to great hardhips from the want of an immediate refource for neceffary food. This ufeful grain grows in the water where it is about two feet deep, and where it finds a rich muddy foil. The ftalks of it, and the branches or ears that bear the feed, refemble oats both in their appearance and manner of growing. The ftalks are full of joints, and rife more than eight feet above the water. The natives

gather 


\section{( 489 )}

gather the grain in the following manner: nearly about the time that it begins to turn from its milky ftate and to ripen, they run their canoes ints the midnt of it, and tying bunches of it together juft below the ears with bark, leave it in this fituation three or four weeks longer, till it is perfectly ripe. About the latter end of September they return to the river, when each family having its feparate allotment, and being able to diftinguifh their own property by the manner of faftening the theaves, gather in the portion that belongs to them. This they do by placing. their canoes clofe to the bunches of rice, in fuch pofition as to receive the grain when it falls, and then beat it out, with pieces of wood formed for that purpofe. Having done this, they dry it with fmoke, and afterwards tread or rub off the wutfide hufk; when it is fit for ufe they put it into the fkins of fawns or young buffalos taken off nearly whole for this purpofe and fewe' into a fort of fack, wherein they preferve it till the return of their harveft. It has been the fubject of much fpeculation why this fpontaneous yrain is not found in any other regions of America, or in thofe countries fituated in the 


\section{( 490$)$}

fame parallels of latitude, where the waters are as apparently adapted for its growth as in the climates I treat of. As for inftance, none of the countries that lie to the fouth and eaft of the great lakes, even from the provinces north of the Carolinas to the extremities of Labradore, produce any of this grain. It is true $I$ found great quantities of it in the watered lands near Detroit, between Lake Huron and Lake Erié, but on enquiry I learned that it never arrived nearer to maturity than juft to bloffom; after which it appeared blighted, and died away. This convinces me that the northweft wind, as I have before hinted, is much more powerful in thefe than in the interior parts; and that it is morc inimical to the fruits of the earth, after it has paffed over the lakes and become united with the wind which joins it from the frozen regions of the north, than it is farther to the weftward.

BEANS. Thefe are nearly of the fame Thape as the European beans, but are not much larger than the fmalleft fize of them. They are boiled by the Indians, and eaten elicfly with bear's fien. 


\section{(49i)}

The SOUASH. They have alfo reveral fpecies of the MELON or PUMPKIN, which by fome are called Squafhes, and which ferve many nations partly as a fubftitute for bread. Of thefe there is the round, the crane-neck, the fmall flat, and the large oblong Squarh. The fmaller forts being boiled are eaten during the fummer as vegetables; and are all of a pleafing flavour. The crane-neck, which. greatly excels all the others, are ufually hung up for a winter's ftore, and in this manner might be preferved for feveral months.

I am fenfible that I have not treated the foregoing Account of the natural productions of the interior parts of North America with the precifion of a naturalift. I have neither enumerated the whole of the trees, hrubs, plants, herbs, \&c. that it produces, nor have I divided them into claffes according to their different genera after the Linnæan method: the limits of my Work, in its prefent ftate, would not permit me to purfue the Subject more copiounly. However, if the favour of the Public fhould render a future edition neceffary, as I truft, from the number of Subfcribers who have already favoured me with their Names, will be the cafe, I then propore 


\section{( 492 )}

to enlarge it confiderably, and to infert many interefting particulars and defcriptions, which the fize of the prefent Edition obliges me to curtail or entirely to omit. 


\section{(493)}

\section{A P P E N D I X.}

$7 \mathrm{HE}$ countries that lie between the great 1 lakes and River Miffiffippi, and from thence fouthward to Weft Florida, although in the nidft of a large continent, and at $a$ great diftance from the fea, are fo fituated, that a communication between them and other realms might conveniently be opened; by which means thofe empires or colonies that may hereafter be founded or planted therein, will be rendered commercial ones. The great River Miffiflippi, which runs through the whole of them, will enable their inhabitants to eftablim an intercourfe with foreign climes, equally as well as the Euphrates, the Nile, the Danube, or the Wolga do thore people who dwell on their banks, and who have no other convenience for exporting the produce of their own country, or for importing thore of others, than boats and veffels of light burden: notwithftanding which they have become powerful and opulent ftates. 


\section{( 494 )}

The Mi Piflippi, as I have before obferved, runs from north to fouth, and paffes through the moit fertile and temperate part of North America, excluding only the extremities of it, which verge both on the torrid and frigid zones. Thus favourably fituated, when once its banks are covered with inhabitants, they need not long be at a lofs for means to eftablif́n an extenfivg and profitable commerce. They will find the country towands the fouth almon fpontarieoufly producing filk, cotton, indigo, and tobacco; and the more northern parts, vine, oil, beef, tallow, fkins, buffalowool, and furs; with lead; copper, iron, coals; lumber, corn, rice, and fruits, befides earth and barks for dyeing.

Thefe articles, with which it abounds even to profufion, may be tranfported to the Ocear through this river without greater difficulty than that which attends the conveyanee of merchandize down fome of thofe $\mathrm{I}$ have juft mentioned. It is true that the Miffifippi being the boundary between the Englifh and Spanifh fettlements, and the Spaniards in poffeflion of the mouth of it, they may obftrue the paffage of it, and greatly difhearten thofe who make the firf attempts; yet when the advantages 


\section{$(495)$}

dyantages that will certainly arife to fettlers are known, multitudes of adventurers, allured by the profpect of fuch abundant riches, will flock to it, and eftabliph theruelves, thoug at the expence of rivers of blood.

But thould the nation that happens to be in poffeffion of New. Orleans prove unfriendly to the internal fettlers, they may find a wayinto the Gulph of Mexico by: the River Lberville, which empties itfelf from the Mirfiffippi, after paffing through Lake Maurepas, into Lake Ponchartrain; which has a communication with the fea within the borders of Weft Florida. The River Iberville branches off from the Miffiffippi about eighty miles above New Orleans, and though it is at prefent choaked up in fopne parts, it might at an inconfiderable expence be made navigable fo as to anfwer all the purpofes propofed.

Although the Englifh have acquired fince the laft peace a more extenfive knowledge of the interior parts than were ever obtained be, fore, even by the French, yet many of their productions fill remain unisown. And though I was not deficient either in affiduity or attention during the fhort time I remained in them yet I muft acknowiedge that the intelligence 


\section{( 496 )}

telligence I gained was not fo pperfect as 1 could wim, and that it requires further refearches to make tive world thoroughly acquainted with the real value of there long: hidden realms.

The parts of the Miffifippi of which no furvey has hitherto beent taken, amount to upwards of eight hundred miles, following the courfe of the ftream; that is, from the Illinois to the Ouifconfin rivers. Thofe which lie to the north of the latter are included in the map of my travels. Plans of fuch as reach from the former to the Gulph of Mexico, have been delineated by foveral hands; one of the beft of thefe, according to its fize, now extant, in which is included the whole continent of America, is annexed to this work. And I have the pleafure to find that an actual furvey of the intermediate parts of the Miffiffippi, between the Illinois river and the fea, with the Ohio, Cherokee, and Ouabache rivers, taken on the fpot by a very ingenious Gentleman", is in the prers and will be foon publimed. I flatter myfelf that the obfervations therein

* Thomas Hutchins, Efq; captain in his Majefty's 6oth, or Royal American Regiment of Foot.

contained, 


\section{( 497$)$}

contained, which have been made by one whofe knowledge of the parts therein defcribed was acquired by a perfonal inveftigation, aided by a folid judgment, will confirm the remarks I have made, and promote the plan I am here recommending.

In the map of North America adjoined, I have partitioned the country which lies adjacent to the eaftern borders of the Miffiffippi into plantations or fubordinate colonies; chufing fuch lands only for this purpofe as by being contiguous to fome river, might enjoy all the advantages I have before pointed out. There I have divided by dotted lines, and numbered; that future adventurers may readily, by referring to the map, chufe a commodious and advantageous fituation. I thall alfo here give a concife defcription of each, beginning according to the rule of geographers, with that which lies moft to the north.

It is however neceffary to obferve, that before thefe fettlements can be eftablifhed, grants muft be procured in the manner cuftomary on fuch occafions, and the lands be purchafed of thofe who have acquired a right to them by a long poffeffion: but no greater difficulty will attend the completion of this $\mathrm{K}$ k point, 


\section{( 498$)$}

point, than the original founders of every colony on the continent met with to obftruct their intentions; and the number of Indians who inhabit thefe tracts being greatly inadequate to their extent, it is not to be doubted but they will readily give up for a reafonable confideration, territories that are of little ufe to them; or remove for the accommodation of their new neighbours to lands at a greater diftance from the Miffiffippi, the navigation of which is not efferitial to the welfare of their communities.

No I. The country within thefe lines, from its fituation is colder than any of the others; yet I am convinced that the air is much more temperate than in thofe provinces that lie in the fame degree of latitude to the eaft of it. The foil is excellent, and there is a great deal of land that is free from woods in the parts adjoining to the Miffiflippi; whilft on the contrary the north-eaftern borders of it are well wooded. Towards the heads of the River Saint Croix, rice grows in great plenty, and there is abundance of copper. Though the falls of Saint Anthony are fituated at the fouth-eaft corner of this divifion, yet that impediment will not totally obftruct the navigation, as the River Saint Croix, which 


\section{(499.)}

which runs through a great part of the fouthern fide of it, enters the Miffiffippi juft below the Falls, and flows with fo gentle a current, that it affords a convenient navigation for boats. This tract is about one hundred miles from north-weft to fouth-eaft, and one hundred and twenty miles from north-eaft to fouth-weet:

No. 11. This tract, as I have already defcribed it in my. Journals, exceeds the higheft encomiums I can give it; notwithftanding which it is entirely uninhabited, and the profufion of bleffings that nature has thowered on this heavenly fpot return unenjoyed to the lap from whence they fprung. Lake Pepin, as I have termed it after the French, lies within thefe bounds; but the lake to which that name properly belongs is a little above in the river St Croix ; however; as all the traders call the lower lake by that name, I have fo denominated it, contrary to the information I received from the Indians. This colony lying in unequal angles, the dimenfions of it cannot be exactly given, but it appears to be on an average about one hundred and ten miles long, and eighty broad. 


\section{( 500$)$}

No. III. 'The greateft part of this divition is fituated on the River Ouifconfin, which is navigable for boats about one hundred and eighty miles, till it reaches the Carryingplace that divides it from the Fox river. The land which is contained within its limits, is in fome parts mountainous, and in others confifts of fertile meadows, and fine pafturage. It is furnifhed alfo with a great deal of good timber, and, as is generally the cafe on the banks of the Miffiflippi and its branches, has much fine, open, clear land, proper for cultivation: To thefe are added, an inexhauftible fund of riches, in a number of lead mines which lie at a little diftance from the Ouifconfin towards the fouth, and appear to be uncommonly full of ore. Although the Sau. kies and Ottagaumies inhabit a part of this track, the whole of the lands under their cultivation does not exceed three hundred acres. It is in length from eaft to weft about one hundred and fifty miles, and about eighty from north to fouth.

No. IV. The colony here marked out confifts of lands of various denominations, fome of which are very good, and athers very bad, The beft is fituated on the borders of the Green 


\section{( 501$)$}

Green Bay and the Fox River, where there are innumerable acres covered with fine grafs, moft part of which grows to an aftonifhing height. This river will afford a good navigation for boats throughout the whole of its courfe, which is about one hundred and eighty miles, except between the Winnebago Lake, and the Green Bay:s where there are feveral Carrying-places in the fpace of thirty miles. The Fox River is rendered remarkable by the abundance of rice that grows on its thores, and the almoft infinite numbers of wild fowl that frequent its banks. The land which lies near it appears to be very fertile, and promifes to produce a fufficient fuppiy of all the neceffaries of life for any number of inhabitants. A communication might be opened by thofe who thall fettle here, either through the Green Bay, Lake Michigan, Lake Huron, Lake Erie, and Lake Ontario with Canada, or by way of the: Ouifconfin into the Miffiffippi. This divifion is about one hundred and fixty miles long from north to fouth, and one hundred and forty broad.

No. V. This is an excellent track of land, and confidering its interior fituation has great- 


\section{( 502$)$}

er advantages than could be expected; for having the Miffiffippi on its weftern borders, and the Illinois on its fouth-eaft, it has as free a navigation as moit of the others." The northern parts of it are fomewhat mountainous, but it contains a great deal of clear land, the foil of which is excellent, with many fine fertile meadows, and not a few rich mines. It is upwards of two hundred miles from north to fouth; and one hundred and fifty from eaft to weft:

No. VI. - This colony being fituated npon the heads of the rivers Illinois and Ouabache, the former of which empties itfelf immediately into the Miffiffippi, and the latter into the fame river by means of the Ohio, will readily find a communication with the fea through thefe. Having alfo the River Miamis paffing through it, which runs into Lake Erie, an intercourfe might be eftablinhed with Canada alfo by way of the lakes, as before pointed out. It contains a great deal of rich fertile land, and though nore inland than any of the others, will be as valuable an acquifition as the beft of them. From north to fouth it is about one hundred and fixty miles, from eaft to weft one hundred and eighty.

No. 


\section{( 503$)$}

No.VII. This divifion is not inferior to any of the foregoing. Its northern borders lying adjacent to the Illinois river, aad its weftern to the Miffiffippi, the fituation of it for eftablifhing a commercial interciourfe with foreign nations is very commodious It abounds with all the neceffaries of life, and is about one hundred and fity miles from north to fouth, and fixty miles, from eait to weft; but the confines of it being more irregular than the others, I cannot exactly afcer:ain the dimenfions of it.

No. VIII. This colony having the River Ouabache running through the centre of it, and the Ohio for its fouthern boundary, will enjoy the advantages of a free navigation. It extends about one hundred and forty miles from north to fouth, and one hundred and thirty from eaft to weft.

No. IX, X. and XI. being fimilar in fituation, and furnithed with nearly the fame conveniencies as all the others, I thall only give their dimenfions. No. IX. is about eighty miles each way, but not exactly fquare. No. $X$. is nearly in the fame form, and about the fame extent. No. XI. so much larger being at leaft one hundred and fifty miles from north 


\section{(504)}

north to fouth, and one hundred and forty from eaft to weft, as nearly as from its irregularity it is poffible to calculate.

After the defcription of this delightful country I have already given, I need not repeat that all the fpots I have thus pointed out as proper for collonization, abound not only with the neceffaries of life, being well ftored with rice, deer, buffalons, bears, \&c. but produce in equal abundance fuch as may be termed luxuries, or at leaft thofe articles of commerce before recited, which the inhabitants of it will have an opportunity of exchanging for the needful productions of other countries.

- The difcovery of a north-weft paffage' to India has been the fubject of innumerable difquifitions. Many efforts likewife have been made by way of Hudfon's Bay to penetrate into the Pacific Ocean, though with iut fuccels. I thall not therefore trouble myfelf to enumerate the advantages that would refult from this much wifhed-for difcovery, its utility being already too well known to the commercial world to need any elucidation; I Thall only confine myfelf to the methods that appear moft probable to infure fuccefs to futrire adventurers.

The 


\section{( 505$)$}

The many attempts that have hitherto been inade for this purpofe, but which have all been rendered abortive, feem to have turned the fpirit of making ufeful refearches into another channel, and this moft interefting one has almot been given up as impracticable; but in my opinion, their failure rather proceeds from their being begun at an improper place, than from their impracticability.

All navigators that have hitherto gone in fearch of this paffage, have firft entered Hudfon's Bay, the confequence of which has been, that having fpent the feafon during which only thore feas are navigable, in ex ploring many of the numerous inlets lying therein, and this without difcovering any opening, terrified at the approach of winter, they have haftened back for fear of being frozen up, and confequently of being obliged to continue till the return of fummer in thofe bleak and dreary realms, Even fuch as have perceived the coafts to unfold themfelves, and who have of courfe entertained hopes of fucceeding, have been deterred from profecuting their voyage, left the winter hould fet in before they could reach a more temperate climate. 


\section{( 506$)$}

Thefe apprehenfions have difcouraged the boldeft adventurers from compleating the expeditions in which they have engaged, and fruftrated every attempt. But as it has been difcovered by fuch as have failed into the northern parts of the Pacific Ocean, that there are many inlets which verge towards Hudfon's Bay, it is not to be doubted but that a paffage might be made o, frt from that quarter, if it be fought for at a proper feafon. And thould thefe expectations be difappointed, the explorers would not be in the fame hazardous fituation with thole who fet out from Hudfon's Bay, for they will always be fure of a fafe retreat, thiough an open fèa; to warmer regions, even after repeated dif appointments. And this confidence will enable them to proceed with greater refolution, and probably be the means of effeaing what too inuch circumfpection or timidity has pres vented:

- Thefe reafons for altiring the plan of enquiry after this convenient paffige, carry with them fuch conviction, that in the year 1774 Richard Whitworth, Efq. memberzof parliament for Stafford, a gentleman of an extenfive knowledge in geography, of an active 


\section{( 507$)$}

active enterprizing difpofition, and whofe benevolent mind is ever ready to promote the happinefs of 'individuals, or the welfare of the public, fort the reprefentitions made to him of the expediency of it by myfelf and others, intended to travel acrofs the continent of America, that he nuight attempt to carry a fcheme of this kind into execution.

He defrgned to have purfued nearly the fame route that $I$ did, and after having built a fort at Like Pepin, to have proceeded up the River St. Pierre, and from thence up a branch of the River Mefforie, till having difcovered the fource of the Oregan or River of the Weft, on the other fide the fummit of the lands that divide the waters which run into the Gulph of Mexico from thofe that fall into the Pacific Ocean, he would have failed down that river to the place where it is faid to empty itfelf near the Straights of Annian.

Having there eftablifhed another fettlement on fome fpot that appeared beft calculated for the fupport of his people, in the neighbourhood of fome of the inlets which tend towards the north-eaft, he would from thence have begun his refearches. This gentleman was to have been attended in the expedition 


\section{( 508$)$}

by Colonsl Rogers, myfelf, and others, and to have taken out with him a fufficient aumber of artificers and mariners for building the forts and veffels neceffary on the occafion; and for navigating the latter; in all not lefs than fifty or fixty men. The grants, and other requifites for this purpofe, were even nearly completed, when the prefent troubles. in America began, which put a ftop to an enterprize that promifed to be of inconceivable advantage to the Britifh dominions. 



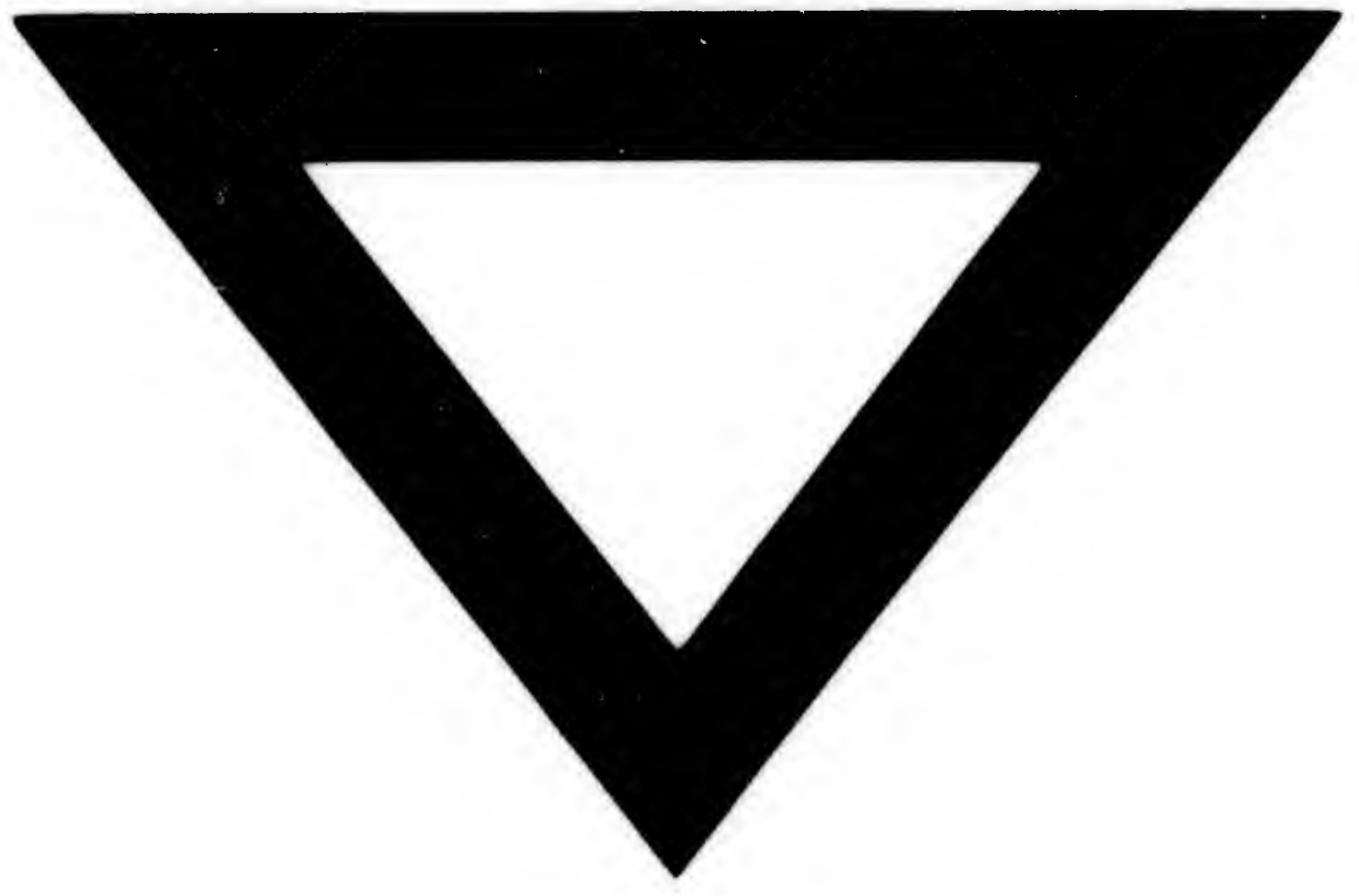

